\title{
THE FEEBLY INHIBITED
}

\section{NOMADISM, OR THE WANDERING IMPULSE, WITH SPECIAL REFERENCE TO HEREDITY}

\section{INHERITANCE OF TEMPERAMENT}

Charles B. Davenport

Director of Department of Experimental Evolution at Cold Spring Harbor

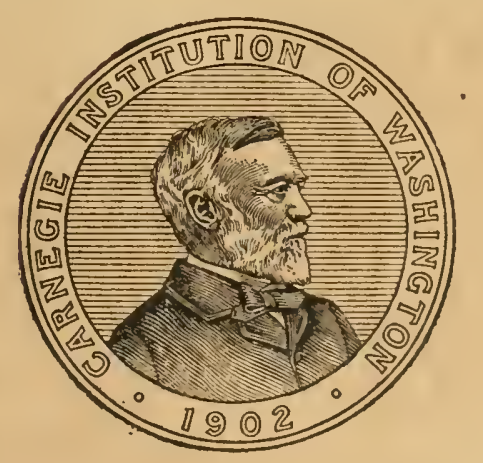

WASHINGTON, D. C.

Q $\mathrm{H} 4.31$ D2? 4 


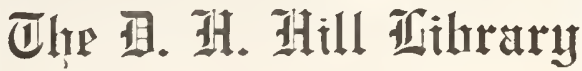

Ninth Caralina State Alniuersity Q11431
D214 


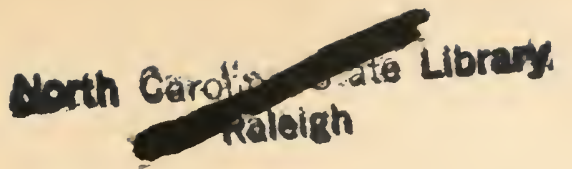 \\ THE FEEBLY INHIBITED}

\section{NOMADISM, OR THE WANDERING IMPULSE, WITH SPECIAL REFERENCE TO HEREDITY}

\section{INHERITANCE OF TEMPERAMENT}

Charles B. Davenport

Director of Department of Experimental Evolution at Cold Spring Harbor

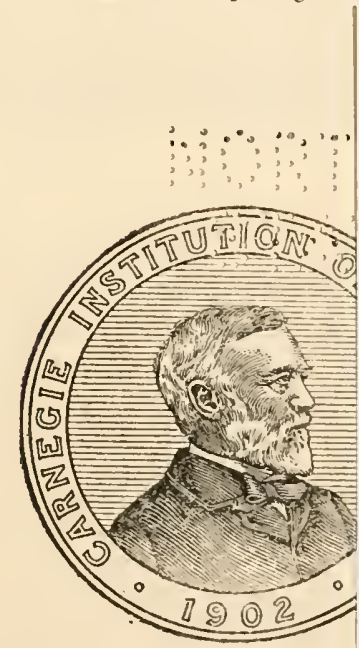

THIS BOOK IS DUE ON THE DATE INDICATED BELOW AND IS SUBJECT TO AN OVERDUE FINE AS POSTED AT THE CIRCULATION DESK.

JUN 27.19987

WASHINGTON, D Published by the Carnegie Institu 1915 


\section{CARNEGIE INSTITU'TION OF WASHINGTON}

Publication No. 236.

PAPER No, 34 OF THE Station for Experimental, Evol,Ution at COLd Spring Harbor, NEW York

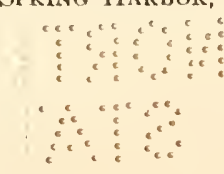

PRESS OF GIBSON BROTHERS, INC WASHINGTON, D. C. 


\section{PREFACE.}

The two studies included in the present volume are the second and third, respectively, of a series of studies on the Feebly Inhibited. The first (on Violent Temper and its Inheritance) was published in the Journal of Nervous and Mental Diseases for September 1915. 'These studies - of which two are in preparation - are principally the outcome of the analysis of a large amount of data collected by trained "eugenics field-workers" acting in connection with various State institutions, and above all with those for wayward girls. Acknowledgment is due to those superintendents and to the field-workers who have co-operated in the study. The following institutions paid part of the expense of collecting the data:

1. State Industrial School for Girls, Lancaster, Massachusetts; Mrs. Amy F. Everall, Superintendent; Mrs. G. W. Hathaway and Dr. Wilhelmine E. Key, field-workers.

2. New Jersey State Home for Girls, Trenton, New Jersey; Mrs. Elizabeth V. H. Mansell, Superintendent; Miss Z. E. Udell, fieldworker.

3. New Jersey State Village for Iipileptics; Dr. David I*. Weeks, Superintendent; Mrs. D. I. F. Woodward and Miss Sadie C. Devitt, field-workers.

4. New Jersey. Home for Feeble-minded Women; Dr. Madeline Hallowell, Superintendent; Miss Helen T. Reeves, field-worker.

5. The Glen Mills (Pennsylvania) Schools, Girls' Department; Miss Martha P. Falconer, Superintendent; Miss Ruth Wanger, fieldworker.

The cost of training the field-workers was met by Mrs. E. H. Harriman, founder and principal patron of the Eugenics Record Oflice, and Mr. John D. Rockefeller, who paid also the salaries of many of the field-workers. This generous assistance is gratefully acknowledged.

A word may be said as to the term "feebly inhibited" used in these studies. It was selected as a fit term to stand as co-ordinate with "feeble-minded" and as the result of a conviction that the phenomena with which it deals should properly be considered apart from those of feeble-mindedness. There is no question of the well-developed intelligence of some of these feebly inhibited individuals. No doubt the content of the term mind could be stretched to cover these emotional phenomena; practically, I think it helps to consider separately the heredity basis of the intellect and the emotions. It is in this conviction that these studies are submitted for thoughtful consideration. For, after all, the chief problem in administering society is that of disordered conduct, conduct is controlled by emotions, and the quality of the emotions is strongly tinged by the hereditary constitution.

C. B. DAVENPORT. 



\section{CONTENTS.}

\section{Nomadism, or the WANdering Impulse, With Special, REFEREnce TO HEREDITY.}

PAGR

1. Scope of the subject-matter and nomenclature. ................ 7

II. Classification of nomadism . . . . . . . . . . . . . . . . . . . . . 8

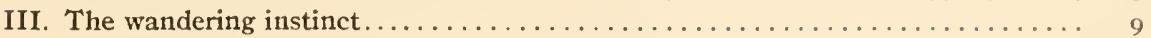

1. The wandering instinct in anthropoid apes................ 9

2. The wandering instinct among primitive peoples............. 10

3. The wandering instinct in children .................... 12

4. Wandering in adolescents. . . . . . . . . . . . . . . . . 12

IV. The family history of nomads: Importance, sources, and classification....... 12

V. Tables showing distribution of the nomadic tendency in the 100 family histories

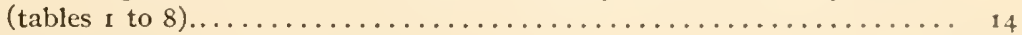

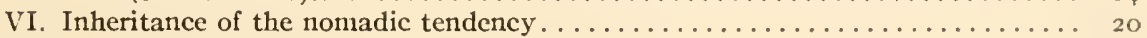

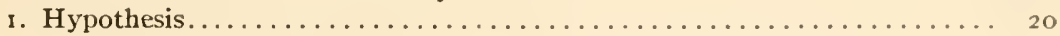

2. Test of the hypothesis (table 9) $\ldots \ldots \ldots \ldots \ldots \ldots \ldots \ldots \ldots \ldots \ldots \ldots$

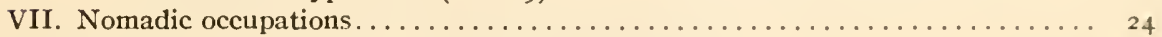

VIII. Association of the nomadic impulse with psychoses . . . . . . . . . . . . 24

IX. Summary . . . . . . . . . . . . . . . . . . . . . . . . . 26

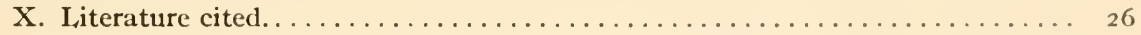

Appendix -Abstracts of 100 family histories of nomads . . . . . . . . 27

\section{INHERITANCE' OF TEMPERAMENT WITH SPECIAL REFERENCE TO TWINS AND SUICIDES.}

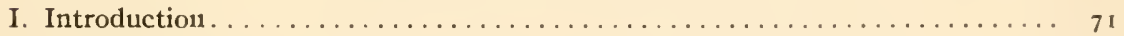

II. Definition . . . . . . . . . . . . . . . . . . . . 71

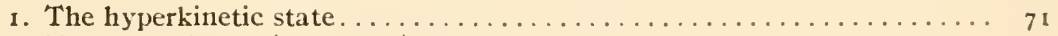

2. The hypokinetic (depressed) state.................... 73

3. The alternation of hyperkinesis and hypokinesis $\ldots \ldots \ldots \ldots \ldots \ldots \ldots$

4. "Normal" mood............................... 74

5. General facts of heredity . . . . . . . . . . . . . . . 75

III. Hypothesis as to heredity . . . . . . . . . . . . . . . . . . 75

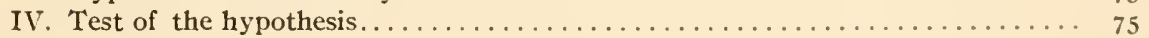

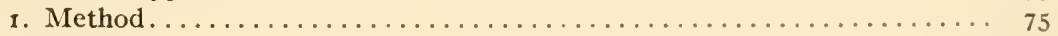

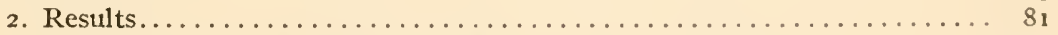

3. Discussion of table $\mathrm{C}$; the apparently unconformable cases......... 88

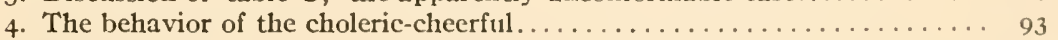

5. Conclusion . . . . . . . . . . . . . . . . . . . . . . . . 94

V. Discussion of earlier studies on heredity of temperanent............ 95

VI. Fvidence for inheritance of temperament drawn from studies of identical twins. 100

VII. Selection of temperaments in marriage...................... 106

VIII. Suicide in relation to temperament. . . . . . . . . . . . . . . . . . . 108

1. Introduction. . . . . . . . . . . . . . . . . . . . .

2. Suicides in hyperkinetics.......................... I09

3. Suicides in hypokinetics. ........................ 113

4. The inheritance of these two types of suicides $\ldots \ldots \ldots \ldots \ldots \ldots \ldots \ldots$ i 4

IX. The specificity of the suicidal inpulse . . . . . . . . . . . . . . . 116

X. Remarks on the categories of functional insanity............... 118

$\mathrm{XI}$. The hyperkinetics and the hypokinetics in the population-the romantic and the classic types . . . . . . . . . . . . . . . . . . . . . . . 19

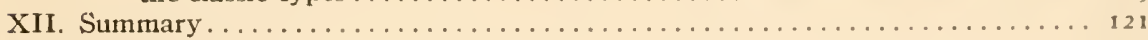

XIII. Literature cited. . . . . . . . . . . . . . . . . . . . . . . . . 123 
Pedigree charts and descriptive legends of the 89 families studied

\section{LIST OI' TABLES.}

TABLE A.-Zygotic formulæ of descendants of a mixture of excited and depressed

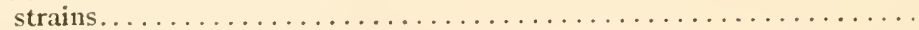

B.-Most probable distributions of temperaments in the offspring corresponding to each combination of temperamental zygotic make-up of the parents.................................. 79

C.--Distribution of progeny of the various inatings compared with hypothetical expectation ........................... 82

D.-Comparison of Sums from table C........................ 89

E.-A comparison of the actual frequency of varions matings with expected frequency on the assumption of mating at random . 


\title{
NOMADISM, OR THE WANDERING IMPULSE, WITH SPECIAL REFERENCE TO HEREDITY
}

\author{
BY \\ Charles B. Davenport \\ Director of Department of Experimental Evolution \\ at Cold Spring Harbor
}





\section{NOMADISM, OR THE WANDERING IMPULSE, WITH SPECIAL REFERENCE TO HEREDITY.}

\section{SCOPE OF THE SUBJECT-MATTER AND NOMENCLATURE.}

It is a familiar observation that persons differ greatly in their capacity for remaining quiet and satisfied for a long period in one place. One occasionally meets a woman who, though living within 30 miles of a metropolis, has, in the 80 years of her life, been there only once. At the other extreme are the trainps and gypsies who travel constantly or with only slight intermissions and many of whom have repeatedly visited all quarters of the globe. An extreme in another direction includes those who, while capable of steady and effective work, at more or less regular periods run away from the place where their duties lie and travel considerable distances, either fully conscious and oriented, or in a dazed condition, or, it may be, living in a secondary, ordinarily submerged, state of consciousness (trance or fugue). Thus human locomotor responses range from sessility and extreme domesticity to "ambulatory automatism.."

A term is needed to apply to these cases in all of their variety; and it is not easy to decide on one. The German word "Wandertrieb" is satisfactory, implying an impulse to wander or travel. The word "Wanderlust" (often and not improperly used as an English word) implies a rather mild form of desire for and love of travel. Vagabondage and vagrancy connote too much of pauperism and low social status for our purpose. Fugue is usually applied to the extreme cases, of most markedly pathological nature, where normal consciousness is impaired. Dromomania has been used as a synonym of ambulatory automatism. Nomadisin has often been applied to a racial or tribal tendency to wander. On the whole, I am inclined to use the word "nomadism" just because it has a racial comnotation. From a modern point of view all hereditary characters are racial. Moreover, the term "nomadie" is in good use for the restless, wandering type. Says Lowell (Fireside Travels, p. 97) "The American is nomadic in religion, in ideas, in morals, and leaves his faith and opinions with as much indifference as the house in which he lives." In view of this usage and the convenience of the word, the phenomenon with which this paper deals will be called nomadism. 


\section{CLASSIFICATION OF NOMADISM.}

Various attempts have been made to classify cases of nomadism. Of these one of the most elaborate is that of Meunier (1908) which is reproduced here in simplified form:

A. Nomads of economic or social origin.

I. Legitimate nomads.

(I) Laborers without work; (2) exiles; (3) representatives of traveling professions (traveling men, peddlers, explorers, missionaries).

II. Delinquent nomads.

Fugitives from justice, recidivists of prisons and asylums, and certain dangerous degenerates.

B. Nomads of morbid origin.

I. Pliysical insufficiency.

(I) Temporary (c.g., children, adults, sick); (2) definitive (old men and the infirm).

II. Psychic insufficiency.

(I) Neurotic; neurasthenic, hysteric, epileptic, "original and eccentric," degenerate.

(2) Psychopathic: the excited-depressed, the recurrent, the paranoiic and mystic, the intoxicated (alcoholic, pellagric), the demented (precocious, senile, and paralytic).

C. Nomads of ethnic origin.

Goths, Saxons, Huns, Normans; Crusaders; Gypsies, Arabs, Sioux, etc.

Joffrey and Dupouy (I 909) use a simpler classification, as follows:

I. Fugues of childhood.

2. Vagabondage and fugues in the feeble-minded.

3. The fugues of the unbalanced (including capricious, sexual, dromomanic, paranoiic).

4. 'The fugues of the manic-depressive.

5. The confusional fugues.

6. Ambulatory automatism of alcoholic or epileptic origin.

Parent (I 909) has suggested a classification of fugues as: (I) melancholic; (2) somnambulistic; (3) epileptic; (4) impulsive and denented (of dementia precox); (5) dromomanic; (6) of the second state (e.g., hypnotic or of "double personality"); (7) systematized; (8) banal.

A consideration of these three classifications of forms of nomadism leads to the inquiry: What do they mean? Are they groups of mental idiosyncrasies each of which is due to a distinct and independent set of causes; or have they all the same primary cause at bottom, so that the different manisfestations are due to a difference in secondary causes-depression, epileptic attack, dementia precox, and the rest? The answer to this question can, I think, be secured only from a study of the fanily histories; for these will tell us something of the associated traits and the nature of the stock fron which nonadics arise. Stich family histories are given in the present paper. We shall study them in detail to get such light as they can give us on the true relationship of the different "forms" of nomadism. 


\section{I1I. THE WANDERING INSTINCT.}

A tendency to wander in some degree is a normal characteristic of man, as indeed of most animals, in sharp contrast to most plants; and the well-developed locomotor appendages of the higher animals are correlated with this tendency to move about, be it to seek food, mates, or shelter. In many species the instinct drives an animal to travel far over the earth's surface; thus some migrating birds traverse, twice a year, 60 degrees of the earth's surface or 3,600 miles. On the other hand, certain birds are permanent residents of any place, $i$. $e_{\text {. }}$, they do not travel more than a few miles; for example, many ground birds and other birds of tropical or subtropical oceanic islands. Now, whether a species tends to travel far or tends to stay near its home depends upon its constitutional factors-its instincts. The differences between men in respect to these points are as truly specific as the differences between swallows and grouse, and are as truly due to differences in inherited instincts.

The fact that in an individual man the strength of the wandering instinct varies may be regarded as evidence that it is not a constitutional trait. Of these variations there can be no doubt. In typical manic-depressives the same individual may at one time fail to respond to a stimulus which at another time causes extraordinary outbursts of activity. As our family histories show, the nomadic may be contented at home for weeks or even months and then suddenly follow the impulse to go away. Many persons who are nomadic in their youth settle down in later years. But these facts, instead of militating against the view that nomadism in man is of the same order as that of birds, support the view, for the migrating birds feel the impulse to migrate periodically-twice a year-and the same is true of certain migrating mammals; and that the nomadic instinct should fail later in life is just what the sexual and many other instincts do.

Lest the argument for a wandering instinct based on a comparison of man with birds may seem far-fetched, four other sets of facts may here be adduced: (I) that the wandering instinct is in the anthropoid apes, which show the same basal instincts that man does; (2) that many if not most primitive peoples are migratory; $(3)$ that the tendency to run away is extraordinarily frequent among young children; and (4) that the adolescent period, when all instincts (and especially those in any way connected with sex) are brought to the surface, is perhaps the commonest period for running away. This evidence we slall consider in detail.

\section{THE WANDERING INSTINCT IN ANTHROPOID APES.}

That the chimpanzee and the gorilla are nomadic in their native forest and "seldom or never pass two nights in the sanle spot" is asserted by Garner (I 890 , p. 97), who has probably studied then at home more thoroughly than any other man. Of the gorilla he says 
further (p. 233) that it "is nomadic and rarely ever spends two nights in the same place. Each family roams about from place to place in the brush in search of food, and wherever they may be when night comes on there they select a place to sleep." The wanderings are frequently made in groups of as many as Io or I2. If a gorilla is met with "alone in the forest, it is usually a young male about reaching the state of manhood; it is probable that he has then set out for himself and that he is in search of a wife." All the facts that we have thus indicate that the group of animals to which the ancestors of man belonged were typical nomads.

\section{THE WANDERING INSTINCT AMONG PRIMITIVE PEOPLES.}

If we regard the Fuegians, ${ }^{1}$ Australians, Bushmen, and Hottentots as the most primitive men, then we may say that primitive man is nomadic. These nomadic peoples are hunters; it is frequently assumed that they are nomadic because they hunt, but it is more probable that their nomadic instincts force them to hunting rather than agriculture for a livelihood.

In some people that are less primitive the wandering instinct still persists. Many nomadic tribes live in Central Asia, alongside of cultivators of the soil, and some of these are here briefly referred to. "The Kirghiz-Kazak (Cossacks) of the plains between the Irtish and the Caspian, with the Kara-Kirghiz of the Tian-chan Mountains" are typical nomads (Deniker, I906, p. 376). "The Turkomans who occupy sterile lands from the Caspian Sea to Balkh and from the Oxus south to Herat and Asterbad in Persia" offer the purest Turkish type, since the desert in which they have lived for ages has protected them from contamination; some are settled, others nomads; "they recognize no chief; everyone is independent." The Mongols of Central Asia, whom Genghis Khan in the thirteenth century organized into a great empire, were, and their descendants still are, a wandering people. From Asia also came forth the Polynesians, the most remarkable nomads the world has seen. At about the beginning of our era they began to spread from India to Java, to Samoa, and to Tahiti, whence they traversed 2,000 miles of ocean in one direction to New Zealand, 2,500 miles in another direction to Hawaii, 2,500 miles in still another direction to Easter Island, and they went these vast distances over uncharted seas in open boats propelled by paddles!

In Asia also has originated the race of Gypsies whose nomadic traits have forced them upon the attention of the civilized world. The

1" Of the social relations of the Pecheré (Fuegians) *** little can be said. They have no villages and rarely any fixed abodes or houses or huts, but lead an unsettled life, which they spend mostly upon the water" (Kingsley, 1885, p. 264). "The free Bushmen are the Gypsies of South Africa, for they have an unconquerable desire for wandering and never become accustomed to fixed abodes" (Kingsley, 1885, p. 273-74). "Everything which the Hottentots have and do has the impress of their tendency to roam" (Kingsley, 1885, p. 281). 
Gypsies probably originated in India, since their language is akin to Sanskrit; some of them made their way into southeastern Europe, and in 1893 there were 275,000 of them in Hungary, of whom only about 9,000 were nomads. Rumania had over 200,000 in 1895; and the other southern countries had each some thousands. Referring to their early incursions into Central Europe, Gaster says: "Their inborn tendency to roaming made them the terror of the peasantry and the despair of every legislator who tried to settle them on land." "They have no ethical principles and they do not recognize the obligations of the ten commandments. There is extreme moral laxity in the relations of the two sexes and, on the whole, they take life easily and are complete fatalists; at the same time they are great cowards." "Their life has been set forth in fiction by Barrow, Leland, and others, and scientific archives (e.g., The Journal of the Gipsy Lore Society) contain important results of study.

Among the natives of America, also, numerous nomadic races appeared interspersed with the non-nomadic. Such are the Muras of the Amazon region, who "wander about on the banks of rivers and lakes catching fish and tortoises" (Kingsley, I885, p. 247); the Tupis, who are scattered about Brazil; and numerous other native tribes of South America. Many of the tribes of Indians of North America were nomadic, which is why the tepee was a favorite form of dwelling. Such are, or were, the Sioux, the Comanches, and other tribes of the plains and mountains.

A general consideration of the foregoing cases of nomadic tribes, only a portion of all, leads to the conclusion that a wandering tendencyan absence of fixed abode-is widespread over the globe. Indeed, it might be said that fixity of abode is a relatively recent acquisition, as yet found only in certain peoples in which the sedentary habit is highly developed; and that, consequently, it is not to be wondered at if even in a non-nomadic people like most of the Chinese, the French, or the Swiss, the racial trait of nomadism should persist in certain families or, after having been eliminated, have crept in again. In modem America, which has lured to itself the restless and tlose in whom the love of ancestral home is weak, we are not surprised to find many families showing the nomadic trait. It is such that lave yielded material for our study. For the most part individuals of our civilization who have the nomadic impulse are capable of inhibiting it to sone degree, since it is incompatible with the mores. But in certain individuals whose inhibitory mechanism is slightly developed and in others in whon it is readily paralyzed from time to time this nomadic tendency shows itself.

\footnotetext{
'In almost every case the nomadic tribes are characterized by a love of lunting - of the cluase; by fondness for horses, where they are avilable; and by a thieving propensity, or at least a lack of appreciation of property rights.
} 


\section{THE WANDERING INSTINCT IN CHILDREN.}

The tendency to rum away is extraordinarily common among young children. We have the testimony of G. Stanley Hall (1904, II, p. 376) that, since settled life is a recent development, "children, true to their function of revealing the past, sometimes almost as soon as they have acquired the upright method of locomotion, as if intoxicated by 'outof-doors,' start off and, by some inner impulse, go on and on with no idea of where or why, tempted by an open gate or by the instinct to follow a man or vehicle, or as a just-hatched chick follows any moving thing." Kline ( 1898, p. 58 ), who has carefully collected data on this subject, finds a maxim of runaways for the first decade of life at 5 years and a high frequency at 3 years, and he states that all children that run off from I to 3 do so impulsively.

\section{WANDERING IN ADOLESCENTS.}

At the adolescent period, when instincts are most highly developed, a strong impulse to migrate or wander is again shown. In Kline's (1898) collection of 50 r runaways the greatest number ( 52 cases) occurred at the age of 15 years, with high numbers at 13 and 14 years. In the wanderings of this period a "love of adventure" is the reason of tenest given. But this is only the individual's interpretation of the unrecognized first call of the mating instinct.

\section{THE FAMILY HISTORY OF NOMADS: IMPORTANCE, SOURCES, AND CLASSIFICATION.}

Admitting the universality in man of the fundamental wandering instinct, we have still to explain the variety of its forms, and particularly its frequent association with various psychoses. It is in the conviction that nomadism in man is a racial character that we turn to a study of family histories. Such histories will reveal, first, the manner of inheritance of the nomadic behavior in adult men and women of modern America, and secondly, the meaning of the association of the nomadic tendency with various psychoses.

The family histories that are deposited at the Eugenics Record Office afford a fair number of cases of nomadism in one of its protean forms. These histories are given in extenso here in order that the critical reader may judge of the value of the evidence upon which the conclusions of this paper are based. All histories are given; there has been rejection of none. It is to be noted that in nearly a third of the cases there is no knowledge of the parents, $i$. e., the history is fragmentary. These cases are included because the personal history is not unimportant and the traits with which it is associated in different members of the principal fraternity are of great interest. In these histories some of the words used by the recorder, which refer to nomadism, are given in italics. Occasionally italics are used to call attention to periodic 
phenomena in other menbers of the family. The source of the histories is very diverse; there have been about 40 contributors to the set, including 26 field workers trained to observe and describe, but wholly innocent of the presence of any law in the recurrence of traits in the family history they submitted. The other contributors have, for the most part, merely filled out a schedule of the traits of their own immediate families. It is to be said, moreover, in partial explanation of the fragmentary nature of many of the pedigrees, that in no case was it expected that they would be used in a study of nomadism; the presence of this trait was not particularly looked for nor inquired into; the information was gleaned incidentally in the course of conversations with parents and others concerning the family history. In a word, the data are recorded without possible bias.

The order in which the histories are liere given is one of convenience for further reference. The less complete listories are placed at the end. The reference numbers are to the files in the records of the Eugenics Record Office. Any statement can be immediately checked by this reference to the original source. The abbreviation $S x$ is frequently used as a symbol indicating uncontrolled eroticism, leading to various unsocial acts in the sex-realm.

The family histories considered in this section are 100 in number. They might, theoretically, be grouped into 9 classes, as follows: (A) father nomadic and mother either (I) nomadic, (2) non-nomadic but of nomadic stock, (3) non-nomadic and, so far as known, not of nomadic stock; (B) father non-nomadic, and, so far as known of nonnomadic stock, and mother either (4) nomadic, (5) non-nomadic of nomadic stock, and (6) so far as known of non-nomadic stock; (C) father non-nomadic, but of nomadic stock, and mother either (7) non-nomadic of nomadic stock, (8) of non-nomadic or unknown stock, (9) nomadic. Class 9 happens not to be represented in our histories. In arranging the histories those of class 5 are placed first, as they constitute the most numerous and typical class, containing about 40 per cent of all the fraternities described in the tables and more than three-fourths of the fraternities that are complete enough to give a fair record of the maternal side. Next in order follow classes $4,1,2,3,7,8$, and 6 , the last class being that which comprises the most fragmentary histories. 


\section{TABLES SHOWING DISTRIBUTION OF THE NOMADIC TENDENCY IN THE 100 FAMILY HISTORIES.}

\section{EXPLANATION OF THE TABLES.}

A table is a convenient and compact form for giving much information. But there is always danger associated with such compactness and conciseness; above all the danger of recording as equivalent (e.g., by the latter $W$, the symbol of nomadism) reactions that are really different. Especially in a statistical comparison of $W$ and Not-W, it is important to define what kinds of behavior are to be classed as evidence of nomadism. It is unreasonable to expect that field workers or volunteer collaborators shall always use the word "nomadism" or "wandering" and I have classified as such a number of traits that appear in individuals who, by hypothesis, may be expected to show nomadism; these are: hunter and fisher (Nos. 3, 5I ), sailor, sea-captain (No. I5), stage-driver (Nos. 4, 20, 38), tinkerer (No. 56), "ran away to go to war," "wandering while insane." Just as the nomadic races live by hunting and fishing, it is suggestive to find these occupations in not a few of the families with nomadism. While perhaps not all sailors have a wanderlust, conversation with seamen soon proves that a large proportion of them were lured to the sea in their youth by a love of travel. To a less degree the love of change of scene and moving about makes railroading (and even stage-driving) attractive to many of these strains; and just as the gypsies are often tinkerers, so we find among our nomadic families the term "peddler" and "tinkerer" employed. The attribution of any of these terms is prima facie evidence of nomadism in the subject; at least they can not be regarded as opposing the hypothesis.

In the tables attention is called to many cases of periodic behavior in individuals who do not show nomadism. Examples of such behavior are epilepsy, fits of absent-mindedness, dipsomania, migraine. These are important, since there is reason for believing that a tendency to periodicity is an inheritable trait and takes different forms in different individuals of different constitution.

The family number is given in the first column. This is repeated in several instances, because there are sometimes 2 fraternities in the same family that show nomadism. The classification of offspring follows; the first column gives the total number; the next column the number whose traits are unknown (x), then the number who died young or at an age before the nomadic trait is ordinarily noted. The following four columns give for males $\left(\sigma^{7}\right)$ and females ( $q$ ) respectively the number of nomadic (W) and non-nomadic (Not-W) individuals. Next is a column ( $F$ ) which records the father's traits that are related to nomadism or its absence, $(\mathrm{N}$, normal). The column $(\mathrm{M})$ does the same for the mother. Columns for a statement concerning brothers (M's bro.) and father (MF) of the mother are provided where necessary. 
The abbreviations used are as follows:
A. Alcoholic.
F. (n column) Feeble-minded. Ne. Neurutic
C. Criminalistic.
1. Insatue.
Pe. Periodic
Dip. Dipsomanic.
M. (at head of colnumn). Sx. Erotic.
E. Epileptic.
Mother.
Ecc. Eccentric. MF. Mother's father.
F. (at head of column) Father. MM. Mother's mother.
FM. Father's mother.
IF. Father's father.
M. (in column) Migraine.
N. Normal.
Tp. Temper.
W. Nonadic, showing wan-
derlust.
$x$. Unknown.
$\dagger$ yg. Died young.

TABLE 1.-Distribution of nomadism or wanderlust (W) in offspring when the father is not nomadic and belongs to a strain in which no nomadism is known, and the mother, though not nomadic, belongs to a family" showing nomadism; together with the distribution of nomadism in near male relatives of the mother (class 5).

\begin{tabular}{|c|c|c|c|c|c|c|c|c|c|c|c|c|c|}
\hline \multirow{3}{*}{$\begin{array}{l}\text { Fam. } \\
\text { No. }\end{array}$} & \multicolumn{7}{|c|}{ Offspring. } & \multirow{3}{*}{ Ji. } & \multirow{3}{*}{ M. } & \multirow{2}{*}{\multicolumn{2}{|c|}{$\begin{array}{l}\text { M's } \\
\text { bro- } \\
\text { thers. }\end{array}$}} & \multirow{3}{*}{$M F$. } & \multirow{3}{*}{ Remarks. } \\
\hline & \multirow[b]{2}{*}{ Tot. } & \multirow[b]{2}{*}{$x$. } & \multirow[b]{2}{*}{$\begin{array}{c}+ \\
y g\end{array}$} & \multicolumn{2}{|c|}{$0^{x}$} & \multicolumn{2}{|r|}{$q$} & & & & & & \\
\hline & & & & W & $\cdot \frac{3}{3}$ & $W$ & $\frac{1}{2}$ & & & W. & $\underset{3}{3}$ & & \\
\hline I & 3 & o & 1 & I & 1 & o & c & $\mathrm{N}$ & $\mathrm{M}$ & o & o & W & $\begin{array}{l}\text { Mother has } 2 \text { sisters of good repute; MI was a } \\
\text { Western desperado who married a good woman. }\end{array}$ \\
\hline 2 & 4 & $a_{1}$ & o & 1 & . & o & $b_{2}$ & $\mathrm{Ne}$ & $\mathrm{Sx}$ & $c_{2}$ & I & ${ }^{d} \mathbf{X}$ & $\begin{array}{l}\text { "At } 12 \text { "very unnanageable; "both highly erotic; } \\
c_{\text {one }} \text { "renoved to Texas," one is "away most } \\
\text { of the time"; } \mathrm{MM} \text { has an epileptic sister } \\
\text { whose son "went to sea." }\end{array}$ \\
\hline 3 & 4 & o & o & 2 & 2 & o & c & $\mathrm{N}$ & $N$ & o & 1 & ${ }^{a} \mathrm{~W}$ & $\begin{array}{l}\text { "MF has } 1 \text { brother who is a wanderer and } 2 \\
\text { about whom there is uncertainty. }\end{array}$ \\
\hline 3 & 6 & 2 & 2 & $\mathbf{I}$ & I & 0 & 0 & $x$. & $\mathrm{N}$ & o & I & ${ }^{a} \mathrm{~W}$ & ${ }^{a}$ A bear-hunter of note. \\
\hline 4 & 6 & o & 2 & 2 & $\mathbf{I}$ & $\mathbf{I}$ & 0 & $\mathbf{x}$ & $\mathrm{x}$ & $\mathbf{x}$ & $\mathbf{x}$ & ${ }^{a} \mathrm{~W}$ & ${ }^{a}$ A stage-driver. \\
\hline 5 & 6 & o & 3 & $a_{2}$ & I & o & 0 & A & ${ }^{b} \mathrm{~N}$ & 2 & o & $N ?$ & ${ }^{a}$ One is $\mathrm{l} ;{ }^{b} \mathrm{MMI}$ had $\mathrm{E}$. \\
\hline 6 & 2 & o & I & I & . & o & 0 & $\mathrm{Ne}$ & $\mathrm{E}$ & 2 & $a_{3}$ & $\mathrm{~N}$ & $\begin{array}{l}{ }^{a} \text { Born in Canada, one has removed to Wisconsin } \\
\text { and one to Minnesota. }\end{array}$ \\
\hline 7 & 5 & o & o & $a_{2}$ & $a_{3}$ & o & o & $x$ & A & I & 1 & A & $\begin{array}{l}\text { a"All wild and unmanageable," details inade- } \\
\text { quate; apportioned somewhat arbitrarily. }\end{array}$ \\
\hline 8 & 4 & o & o & 2 & I & o & $a_{1}$ & $\mathrm{~N}$ & $\mathrm{Ne}$ & I & $b_{1}$ & $\mathrm{x}$ & $\begin{array}{l}{ }^{a} \text { Has hysterical attacks and is } \mathrm{Sx} ;{ }^{b} \text { went from } \\
\text { Fingland to Anerica, returned; not heard } \\
\text { from since. }\end{array}$ \\
\hline 9 & 3 & o & o & $\mathbf{I}$ & I & o & $a_{\mathrm{I}}$ & A & I & o & o & W & ${ }^{a} \mathrm{E}:$ \\
\hline 10 & 4 & o & o & I & o & o & $a_{3}$ & $N$ & Sx & 2 & o & $N$ & ${ }^{a}$ One has fits of absent-mindedness. \\
\hline II & 8 & o & $\mathbf{I}$ & I & $\mathbf{I}$ & o & 5 & $\mathbf{N}$ & $\mathbf{M}$ & 1 & 2 & $\mathrm{~N}$ & \\
\hline 12 & 2 & o & o & I & $\mathbf{I}$ & o & c & $\mathrm{N}$ & $\mathrm{Ne}$ & 0 & o & ${ }^{a} \mathrm{~W}$ & ${ }^{a}$ Deserted from the army; went on sprees. \\
\hline 13 & 8 & o & o & $\mathbf{I}$ & 2 & o & $a_{5}$ & $\mathrm{Ne}$ & $\mathrm{Ne}$ & $b_{1}$ & o & $\mathbf{x}$ & $\begin{array}{l}\text { ane of these sisters, patient at State Hospital. } \\
b_{A} \text { sister was "inclined to wander away." }\end{array}$ \\
\hline 14 & 3 & o & o & I & o & o & 2 & $\mathbf{x}$ & $\mathrm{x}$ & $?$ & ? & ${ }^{a} \mathbf{W}$ & ${ }^{a}$ A canal-boat captain. \\
\hline 15 & 3 & o & o & 1 & o & o & 2 & $\mathbf{N}$ & $\mathrm{N}$ & 0 & 0 & ${ }^{a} \mathrm{~W}$ & ${ }^{a}$ A slip-captain. \\
\hline 16 & 8 & . & I & $a_{5}$ & I & . & I & $\mathbf{N}$ & $\mathrm{N}$ & 1 & $b_{2} ?$ & ${ }^{c} \mathbf{N} ?$ & $\begin{array}{l}{ }^{a} \text { No. I, a sailor; } 2 \text {, a traveling salesnuan; } 3 \text {, a } \\
\text { sailor and railroad man; } 4 \text {, a sailor and railroad } \\
\text { man; } 5 \text {, railroading; }{ }^{b} \text { loth now dead and not } \\
\text { well known; }{ }^{c} \text { navigator, W? }\end{array}$ \\
\hline 17 & I & o & o & I & o & o & o & $\mathbf{N}$ & $N$ & I & . . & ${ }^{a} \mathbf{W} ?$ & ${ }^{a}$ At one time an itinerant tinkerer $(\mathrm{N}$ ?). \\
\hline 18 & $\mathbf{I}$ & o & o & I & o & o & 0 & $\mathrm{Ne}$ & $\mathrm{N}$ & I & 2 & ${ }^{a} \mathrm{WV} ?$ & ${ }^{a}$ Travels through the country with artists (N?). \\
\hline 19 & 7 & o & 3 & I & 2 & o & 1 & Ne & $\mathrm{N}$ & 2 & 1 & $\mathrm{~N}$ & \\
\hline 20 & 4 & o & o & $\mathbf{I}$ & $\mathbf{I}$ & o & 2 & $\mathrm{x}$ & ${ }^{a} \mathrm{Ne}$ & 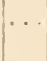 & $a_{2}$ & ${ }^{b} \mathrm{~N}$ & $\begin{array}{l}{ }^{a} \text { All depressed at times; }{ }^{b} \mathrm{MM} \text { liad } 2 \mathrm{~W} \text { (?) brothers } \\
\text { and I that was not W. }\end{array}$ \\
\hline 21 & I & o & o & I & o & o & 0 & $\mathrm{x}$ & Sx & o & o & $a \mathrm{WV}$ ? & ${ }^{a}$ A ship-carpenter. \\
\hline 22 & 7 & 2 & 2 & $\mathbf{I}$ & 2 & o & o & $N$ & $N$ & $a_{t}$ & 2 & $\mathbf{x}$ & ${ }^{a}$ Sailed away as a young man. \\
\hline 23 & 2 & o & o & I & 0 & o & 1 & $\mathbf{N}$ & $\mathbf{M}$ & 1 & $a_{1}$ & ${ }^{b} \mathrm{~N}$ & ${ }^{a}$ Restless; ${ }^{b}$ wife liad migraine. \\
\hline 24 & 4 & o & o & 2 & I & o & I & $N$ & $\mathrm{Ne}$ & 1 & 4 & $x$ & \\
\hline 25 & 9 & o & $\mathbf{I}$ & 3 & $a_{2}$ & o & $b_{3}$ & $\mathrm{~N}$ & 1 & o & 2 & ${ }^{a} \mathrm{~W}$ & $\begin{array}{l}\text { ane lias "absent" periods; }{ }^{b} \text { one is restless, does } \\
\text { not work as domestic long in one place; } \\
\text { "would follow one whim one moment and } \\
\text { another the next." }\end{array}$ \\
\hline
\end{tabular}


TABLE I.-Distribution of nomadism or wanderlust $(W)$ in offspring when the father is not nomadic and belongs to a strain in which no nomadism is known, and the mother, though not nomadic, belongs to a family showing nomadism; together with the distribution of nomadism in near male relatives of the mother (class 5)-Continued.

\begin{tabular}{|c|c|c|c|c|c|c|c|c|c|c|c|c|c|}
\hline \multirow{3}{*}{$\begin{array}{l}\text { Fam. } \\
\text { No. }\end{array}$} & \multicolumn{7}{|c|}{ Offspring. } & \multirow{3}{*}{ F. } & \multirow{3}{*}{ M. } & \multirow{2}{*}{\multicolumn{2}{|c|}{$\begin{array}{l}\text { M's } \\
\text { bro- } \\
\text { thers. }\end{array}$}} & \multirow{3}{*}{$\mathrm{MF}$. } & \multirow{3}{*}{ Remarks. } \\
\hline & \multirow[b]{2}{*}{ Tot. } & \multirow[b]{2}{*}{$x$. } & \multirow[b]{2}{*}{$\begin{array}{c}\dagger \\
y g\end{array}$} & \multicolumn{2}{|c|}{$\sigma^{\top}$} & \multicolumn{2}{|c|}{ 운 } & & & & & & \\
\hline & & & & W. & 莌 & W. & 荒 & & & W. & $\begin{array}{l}3 \\
1 \\
0 \\
2\end{array}$ & & \\
\hline 25 & $\mathbf{I}$ & $\ldots$ & $\ldots$ & $\mathbf{I}$ & o & $\cdots$ & ... & $\ldots$ & I & 0 & 2 & ${ }^{a} \mathrm{~W}$ & ${ }^{a}$ Same individual as in line above. \\
\hline 25 & 3 & o & o & $\mathbf{I}$ & 0 & o & 2 & $\mathbf{F}$ & $\mathrm{Ne}$ & o & 2 & ${ }^{a} \mathrm{~W}$ & ${ }^{a}$ Same individual as in line above. \\
\hline 25 & 2 & o & o & $\mathbf{I}$ & I & $\ldots$ & $\cdots$ & Dip & $N$ & o & 2 & ${ }^{a} \mathrm{~W}$ & ${ }^{a}$ Same individual as above. \\
\hline 26 & 4 & o & o & $a_{2}$ & 1 & 0 & $\mathbf{I}$ & $\mathrm{x}$ & $\mathbf{x}$ & o & o & ${ }^{b} \mathrm{~W}$ & ${ }^{a}$ Both educators in Japan; ${ }^{b}$ general in the army. \\
\hline 27 & $\mathbf{I}$ & o & o & $\mathbf{I}$ & 0 & o & o & ? & $\mathbf{N}$ & $\ldots$ & $\cdots$ & ${ }^{a} \mathrm{~W}$ & ${ }^{a}$ Escaped from slavery and ran away to Kansas. \\
\hline 28 & 4 & o & I & I & 0 & o & 2 & $\mathbf{N}$ & $\mathbf{N}$ & $a_{2}$ & 1 & ${ }^{b} \mathrm{~N}$ & $\begin{array}{l}\text { aOne is a "horse man," one enlisted in the army; } \\
{ }^{b} \mathrm{MF} \text { has one brother, who is not } \mathrm{W} \text {. }\end{array}$ \\
\hline 29 & I & o & o & I & 0 & o & $o$ & F & Sx & o & 2 & ${ }^{a} \mathrm{~W}$ & ${ }^{a} \mathrm{Had} 3$ brothers in the Civil War. \\
\hline 29 & 3 & o & o & $a_{1}$ & I & o & I & $\mathbf{N}$ & $\mathrm{Ne}$ & $\mathbf{x}$ & $\mathbf{x}$ & ${ }^{b} \mathrm{x}$ & $\begin{array}{l}{ }^{a} \text { Moved from Massachusetts to California; }{ }^{b} \mathrm{MF} \\
\text { had } 6 \text { brothers, one of whom showed W. }\end{array}$ \\
\hline 29 & I & $\ldots$ & $\cdots$ & 1 & 0 & $\ldots$ & $\ldots$ & $\mathbf{N}$ & Sx & I & 5 & ${ }^{a} \mathrm{~W}$ & $\begin{array}{l}{ }^{a} \text { Has been all over the world as soldier in British } \\
\text { army. }\end{array}$ \\
\hline 30 & 6 & 0 & 2 & 3 & 0 & o & I & $x$ & $N$ & 0 & 4 & W & \\
\hline 31 & 3 & 0 & o & 1 & I & o & I & $\mathrm{N}$ & F & $a_{1}$ ? & 0 & W & $\begin{array}{l}{ }^{a} \text { Served a term in State prison for arson and a } \\
\text { term for threatening to kill. }\end{array}$ \\
\hline 32 & 8 & o & 2 & 2 & I & o & 3 & $\mathbf{N}$ & $\mathrm{N}$ & I & 3 & $\mathrm{~N}$ & \\
\hline 33 & I & o & o & I & 0 & o & o & $\mathrm{Sx}$ & $\mathbf{N}$ & $a_{1}$ & 0 & $\mathrm{~N}$ & ${ }^{a}$ In Philippines. \\
\hline 34 & 3 & $\mathbf{I}$ & $\circ$ & 2 & o & o & o & $\mathrm{Ne}$ & $\mathrm{N}$ & o & 2 & ${ }^{a b} \mathrm{~W}$ & $\begin{array}{l}{ }^{a} \mathrm{MF} \text { had } 5 \text { brothers who did not show } \mathrm{W} \text {; } \\
{ }^{b} \mathrm{MFF} \text { went on sprees. }\end{array}$ \\
\hline 35 & 2 & o & o & I & 0 & o & I & $N$ & $\mathbf{x}$ & $a_{I}$ & $\mathbf{I}$ & & ${ }^{a}$ Lived in China. \\
\hline 36 & 4 & o & $\mathbf{I}$ & $\mathbf{I}$ & 2 & o & o & $\mathbf{N}$ & N & I & o & $\mathbf{N}$ & \\
\hline 36 & 2 & o & 0 & I & o & o & I & $\mathrm{N}$ & $\mathrm{N}$ & o & I & ${ }^{a} \mathrm{~W}$ & $\begin{array}{l}{ }^{a} \text { Fond of Indian out-door life and always used an } \\
\text { Indian blanket; descended from Pocahontas. }\end{array}$ \\
\hline 37 & 6 & I & 0 & I & 3 & 0 & I & $N$ & ${ }^{a} \mathrm{~N}$ & o & I & $x$ & $\begin{array}{l}{ }^{a} \text { The MM had a brother who wandered like his } \\
\text { great nephew, the propositus. }\end{array}$ \\
\hline 38 & 5 & 3 & I & I & o & o & o & $x$ & $\mathbf{x}$ & $a_{1}$ & I & $\mathbf{x}$ & ${ }^{a}$ Drives a stage. \\
\hline 39 & 8 & 3 & o & $\mathbf{I}$ & 3 & 0 & $\mathbf{I}$ & $\mathbf{N}$ & $\mathbf{x}$ & . & & ${ }^{a}$ Eicc & $\begin{array}{l}{ }^{a} \text { Migrated to the United States from Germany; } \\
\text { said to have been queer. }\end{array}$ \\
\hline 40 & 12 & o & I & $a_{4}$ & 2 & o & o & $\mathrm{Ne}$ & ${ }^{b} \mathrm{Sx}$ & $a_{1}$ ? & 2 & A Sx & $\begin{array}{l}{ }^{a} \text { One is a wanderer, } 2 \text { have run away, the youngest } \\
\text { is a constant truant; }{ }^{b} \text { of nomadic stock; } 1 \text { niece, } \\
2 \text { first cousins, and a great aunt are nomadic. } \\
{ }^{a} \text { Died in the army. }\end{array}$ \\
\hline 42 & 8 & o & 3 & o & 3 & o & 2 & A & $\mathbf{M}$ & o & I & W & $\begin{array}{l}\text { None of the } 3 \text { sons show nomadism, where I or } \\
2 \text { cases are expected. }\end{array}$ \\
\hline Total & 210 & 13 & 29 & 68 & 45 & I & 54 & & & 30 & 56 & & \\
\hline
\end{tabular}




\section{North C. Sale Librapy.}

Raleigh

NOMADISM, WITH SPECIAL REFERENCE TO HEREDITY.

TABLE 2.-Distribution of nomadism or wanderlust (W) in off spring when the father is not nomadic and belongs to a strain in which no nomadism is known and the nother is herself nomadic (class 4).

\begin{tabular}{|c|c|c|c|c|c|c|c|c|c|c|}
\hline \multirow{3}{*}{$\begin{array}{c}\text { Fam. } \\
\text { No. }\end{array}$} & \multicolumn{7}{|c|}{ Offspring. } & \multirow{3}{*}{ li. } & \multirow{3}{*}{ M. } & \multirow{3}{*}{ Remarks. } \\
\hline & \multirow{2}{*}{ Tot. } & \multirow{2}{*}{$\mathbf{x}$. } & \multirow{2}{*}{$\begin{array}{c}t \\
y g .\end{array}$} & \multicolumn{2}{|r|}{$\sigma^{7}$} & \multicolumn{2}{|c|}{ q } & & & \\
\hline & & & & W. & $\begin{array}{l}\text { Not- } \\
\text { W. }\end{array}$ & W. & $\begin{array}{c}\text { Not- } \\
\text { W. }\end{array}$ & & & \\
\hline 42 & 6 & 0 & o & $a_{3} \pm$ & $3 \pm ?$ & 0 & o & & W & a"Some of the 6 sons show wanderlust;" statement vague. \\
\hline 43 & 3 & $a_{1}$ & 1 & I & o & o & o & ${ }^{b} \mathrm{Ne}$ & ${ }^{c} \mathrm{~W}$ & $\begin{array}{l}\text { a } \text { Airl } 5 \text { years old; "subject to "spells;" cwandered while } \\
\text { deranged; one of her brothers goes away in "lapses:" }\end{array}$ \\
\hline 48 & 2 & o & o & $\mathbf{I}$ & o & o & $\mathbf{I}$ & $\mathrm{F}$ & W & another is a wanderer. \\
\hline Total & I I & $\mathbf{I}$ & $\mathbf{I}$ & $s^{ \pm}$ & {$[3 \pm]$} & o & $\mathbf{I}$ & & & \\
\hline
\end{tabular}

TABLE 3.-Distribution of nomadism (W) in the off spring when both parents are nomadic (class 1 ).

\begin{tabular}{|c|c|c|c|c|c|c|c|c|c|c|c|c|}
\hline \multirow{3}{*}{$\begin{array}{c}\text { Fam. } \\
\text { No. }\end{array}$} & \multicolumn{7}{|c|}{ Offspring. } & \multirow{3}{*}{$\mathrm{I}$} & \multirow{3}{*}{$M$} & \multirow{3}{*}{$M F$. } & \multirow{3}{*}{$M M$} & \multirow{3}{*}{ Remarks. } \\
\hline & \multirow{2}{*}{ Tot. } & \multirow[b]{2}{*}{$\mathbf{x}$. } & \multirow{2}{*}{$\begin{array}{c}\dagger \\
y g\end{array}$} & \multicolumn{2}{|c|}{$\sigma^{x}$} & \multicolumn{2}{|r|}{ ᄋ } & & & & & \\
\hline & & & & W & $\left\{\begin{array}{l}\text { Not } \\
\text { W. }\end{array}\right.$ & W. & $\begin{array}{c}\text { Not- } \\
\text { W. }\end{array}$ & & & & & \\
\hline 44 & 5 & o & o & $a_{4}$ & I & o & o & w & W & $\mathrm{x}$ & $\mathbf{x}$ & $\begin{array}{l}{ }^{a} \text { Field-worker's statement, which does not entirely } \\
\text { agree with details given in the description. }\end{array}$ \\
\hline 45 & 6 & o & 2 & 2 & o & $a_{2}$ & 0 & W & W & W & $\mathrm{N}$ & $\begin{array}{l}{ }^{a} \text { Of one of these we know only that she married her } \\
\text { music-teacher and lived in the United States and }\end{array}$ \\
\hline 46 & 1 & o & o & o & o & I. & o & W & W & $x$ & $\mathrm{x}$ & abroad. \\
\hline 47 & I & o & o & o & o & I & o & W & W & $\mathbf{x}$ & $\mathrm{x}$ & \\
\hline Total & 13 & 0 & 2 & 6 & I & 4 & o & & & & + & \\
\hline
\end{tabular}

TABLE 4.-Distribution of nomadism (W) in the offspring when the father is nomadic and the mother, though not nomadic, belongs to a nomadic strain, tagether with the distribution of nomadism in near male relatices of the mother (class 2).

\begin{tabular}{|c|c|c|c|c|c|c|c|c|c|c|c|c|c|}
\hline \multirow{3}{*}{$\begin{array}{l}\text { Fam. } \\
\text { No. }\end{array}$} & \multicolumn{7}{|c|}{ Offspring. } & \multirow{3}{*}{ F. } & \multirow{3}{*}{ M. } & \multirow{2}{*}{\multicolumn{2}{|c|}{$\begin{array}{l}\text { M's } \\
\text { bro- } \\
\text { thers. }\end{array}$}} & \multirow{3}{*}{$M F$. } & \multirow{3}{*}{ Remarks. } \\
\hline & \multirow{2}{*}{ Tot. } & \multirow[b]{2}{*}{$\mathrm{x}$. } & \multirow{2}{*}{$\begin{array}{c}\dagger \\
\text { yg }\end{array}$} & \multicolumn{2}{|c|}{$\sigma^{7}$} & \multicolumn{2}{|r|}{ 우 } & & & & & & \\
\hline & & & & W. & Not- & W. & $\begin{array}{l}\text { Not- } \\
\text { W. }\end{array}$ & & & W. & $\begin{array}{l}\text { Not- } \\
\text { W. }\end{array}$ & & \\
\hline 15 & 3 & o & o & I & I & 0 & I & ${ }^{a} \mathrm{~W}$ & $N$ & & & W & $\begin{array}{l}{ }^{a} \text { FF a ship-owner of retiring disposition; FMF, a } \\
\text { ship-captain. }\end{array}$ \\
\hline 49 & 7 & $\mathbf{I}$ & 5 & I & o & 0 & o & ${ }^{a} \mathrm{~W}$ & $\mathrm{~N}$ ? & $b_{1}$ & & ${ }^{c} \mathrm{~W}$ & $\begin{array}{l}{ }^{a} \text { A seaman in the summer; }{ }^{b} \text { one of mother's sisters } \\
\text { shows ambulatory automatisn; }{ }^{c} \text { skipper of a } \\
\text { fishing-vessel. }\end{array}$ \\
\hline 49 & 7 & 3 & o & 0 & I & I & 2 & ${ }^{a} W$ & $\mathrm{Ne}$ & ${ }^{b} I_{1}$ & I & ${ }^{c} \mathrm{~W}$ ? & $\begin{array}{l}{ }^{a} \text { Skipper of a fishing-vessel; }{ }^{b} \text { a seaman; }{ }^{c} \text { drowned } \\
\text { out of a dory. }\end{array}$ \\
\hline 50 & 5 & o & o & 2 & 2 & 0 & I & W & ${ }^{a} \mathrm{~F}$ & & & & $\begin{array}{l}\text { "Also the MII "races the conntryside } 5 \text { days out } \\
\text { of every week." }\end{array}$ \\
\hline $5 \mathrm{I}$ & 6 & o & I & 3 & I & o & I & ${ }^{a} \mathrm{~W}$ & $\mathrm{~N}$ & & & ${ }^{b} \mathrm{~W}$ & $\begin{array}{l}{ }^{a} \text { Has had several places of residence; his father } \\
\text { was a sea-captain; }{ }^{b} \text { pioneer, served in the war } \\
\text { of } 1812 \text {, was fond of fishing. an inventor. }\end{array}$ \\
\hline 52 & 7 & 2 & I & I & o & I & 2 & ${ }^{a} \mathrm{WV}$ & ${ }^{b} I$ & & & $x$ & $\begin{array}{l}\text { A nucherel fisherman in summer; }{ }^{b} \text { a sister had a } \\
\text { son who was for many years a teacher, then }\end{array}$ \\
\hline Total & 35 & 6 & 7 & 8 & 5 & 2 & 7 & & & & & & estate dealer. \\
\hline
\end{tabular}


TABLE 5.-Distribution of nomadism (W) in the offspring when the father is nomadic and on the mother's side no case of nomadism is known (class 3 ).

\begin{tabular}{|c|c|c|c|c|c|c|c|c|c|c|}
\hline \multirow{3}{*}{$\begin{array}{c}\text { Fam. } \\
\text { No. }\end{array}$} & \multicolumn{7}{|c|}{ Offspring. } & \multirow{3}{*}{ F. } & \multirow{3}{*}{ M } & \multirow{3}{*}{ Remarks. } \\
\hline & & & & & $0^{7}$ & & ㅇ & & & \\
\hline & & & & W. & W. & W. & W. & & & \\
\hline 12 & I & 0 & 0 & $y$ & 0 & 0 & 0 & W & $\mathbf{x}$ & \multirow{13}{*}{$\begin{array}{l}{ }^{a} \text { An itinerant tinker. } \\
{ }^{a} \text { Travels through the country with artists. } \\
{ }^{a} \text { Three of these were in the Civil War; }{ }^{b} \text { peculiar, went insane. } \\
{ }^{a} \text { A sailor; }{ }^{b} \text { the mother has no brothers to show the nomadism if } \\
\text { they possessed it; MF is unknown, as his wife early left him } \\
\text { account of his dissolute habits. } \\
{ }^{a} \mathrm{E} ;{ }^{b} \text { Only brother a constable in New Jersey; spent the latter } \\
\text { part of his life in Florida; MF went to the war and died soon } \\
\text { after. } \\
{ }^{a} \text { A brakeman; }{ }^{b} \text { one a wanderer and one on vaudeville stage. } \\
{ }^{a} \text { Tinkerer; }{ }^{b} \text { two are drinkers and one has an E daughter; }{ }^{c} \text { a } \\
\text { "rolling stone;", d"said to have been a good woman;" none } \\
\text { of her relatives known. } \\
{ }^{a} \text { "Of good reputation;" nothing more known about her or her } \\
\text { other relatives. } \\
{ }^{a} \text { Liked to travel, peddled notions; b" not restless;" her sibs } \\
\text { and parents unknown. } \\
{ }^{a} \text { A F brother and FF also W; bloves country walks, has an } \\
\text { erratic brother. } \\
{ }^{a} \mathrm{MF} \text { subject to sprees; mother's sibs unknown. }\end{array}$} \\
\hline 17 & 2 & $o$ & o & I & 0 & 0 & I & ${ }^{a} \mathrm{~W}$ & $\mathbf{x}$ & \\
\hline 18 & 6 & 0 & 0 & I & 2 & 0 & 3 & & $x$ & \\
\hline 29 & II & 4 & 1 & I & $a_{4}$ & 0 & $\delta_{I}$ & W & & \\
\hline 53 & 9 & 3 & I & 2 & 2 & $I$ & o & ${ }^{a} \mathrm{~W}$ & ${ }^{b} \mathrm{~N}$ & \\
\hline 54 & 12 & 6 & 3 & 2 & $a_{1}$ & 0 & 0 & W & ${ }^{b} \mathrm{M}$ & \\
\hline 55 & 8 & I & I & $a_{1}$ & $\circ$ & $b_{2}$ & 3 & W & $x$ & \\
\hline 56 & 5 & 0 & o & $a_{1}$ & ${ }^{b} 3$ & ${ }^{c} \mathbf{I}$ & o & W & ${ }^{d} \mathrm{~N}$ & \\
\hline 57 & 5 & 2 & o & I & o & o & 2 & $\mathrm{~W}$ & ${ }^{a} \mathrm{~N}$ & \\
\hline 58 & 3 & o & 0 & I & 1 & o & I & ${ }^{a} \mathrm{~W}$ & ${ }^{b} \mathrm{~N}$ & \\
\hline 59 & 2 & 0 & o & I & I & o & o & ${ }^{a} \mathrm{~W}$ & ${ }^{b} \mathrm{~N}$ & \\
\hline 60 & 9 & 1 & o & 3 & 2 & 1 & 2 & W & ${ }^{a} \mathrm{~A}$ & \\
\hline Total & 73 & 17 & 6 & 16 & 16 & 5 & 13 & $\ldots$ & & \\
\hline
\end{tabular}

TABLE 6.-Distribution of nomadism (W) in the offspring when the father and mother, while not nomadic themselves, are both of nomadic stock (class 7 ).

\begin{tabular}{|c|c|c|c|c|c|c|c|c|c|c|c|c|c|c|c|c|}
\hline \multirow{3}{*}{$\begin{array}{l}\text { Fam. } \\
\text { No. }\end{array}$} & \multicolumn{7}{|c|}{ Offspring. } & \multirow{3}{*}{ F. } & \multirow{2}{*}{\multicolumn{2}{|c|}{$\begin{array}{l}\text { F's } \\
\text { bro- } \\
\text { thers. }\end{array}$}} & \multirow{3}{*}{$\mathrm{FF}$} & & \multirow{2}{*}{$\begin{array}{c}\text { M's } \\
\text { brother. }\end{array}$} & \multirow{3}{*}{ MF. } & \multirow{3}{*}{ MM. } & \multirow{3}{*}{ Remarks. } \\
\hline & \multirow{2}{*}{ Tot. } & \multirow{2}{*}{$\mathrm{x}$. } & \multirow{2}{*}{$\begin{array}{c}\dagger \\
\text { yg }\end{array}$} & \multicolumn{2}{|c|}{$\sigma^{7}$} & \multicolumn{2}{|r|}{ q } & & & & & & & & & \\
\hline & & & & W. & W. & W. & W. & & W & W & & & W. W. & & & \\
\hline 61 & 4 & o & I & $\mathbf{I}$ & o & o & 2 & $N$ & 2 & 2 & $\mathrm{~N}$ & $\mathrm{~N}$ & $a_{1}$ & $\mathrm{~W}$ & ${ }^{\circ} \mathrm{N}$ & $\begin{array}{l}{ }^{a} \text { Ne? frequented race-tracks for a } \\
\text { time after his father's death; } \\
{ }^{b} \mathrm{MM} \text { brother followed the sea. }\end{array}$ \\
\hline Total & 4 & o & 1 & $\mathbf{I}$ & o & o & 2 & . & 2 & 2 & & & 1 & & & \\
\hline
\end{tabular}


TABLE 7.-Distribulion of nomadism (W) in the off spring when the father, though not himself nomudic. belong: to nomadic stock and on the mother's side of the house no nomadism is knou'n (class $\delta$ ).

\begin{tabular}{|c|c|c|c|c|c|c|c|c|c|c|c|c|c|}
\hline \multirow{3}{*}{$\begin{array}{l}\text { Fam. } \\
\text { No. }\end{array}$} & \multicolumn{7}{|c|}{ Offspring. } & \multirow{3}{*}{ Is. } & \multirow{3}{*}{ 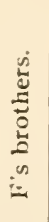 } & \multirow{3}{*}{ Fl: } & \multirow{3}{*}{$\sum_{\infty}^{\infty}$} & \multirow{3}{*}{ M. } & \multirow{3}{*}{ Renlarks. } \\
\hline & \multirow{2}{*}{ Tot. } & \multirow{2}{*}{$\mathbf{x}$} & \multirow{2}{*}{$\begin{array}{c}t \\
\text { yg. }\end{array}$} & \multicolumn{2}{|c|}{$\sigma^{7}$} & \multicolumn{2}{|r|}{9} & & & & & & \\
\hline & & & & W. & $\begin{array}{l}\text { Not- } \\
\text { W. }\end{array}$ & W. & $\begin{array}{l}\text { Not- } \\
\text { W. }\end{array}$ & & & & & & \\
\hline 29 & 2 & o & o & 1 & 1 & o & 0 & A & I W & WV & . & $x$ & Half fraternicies \\
\hline 29 & 3 & 0 & 1 & 1 & 1 & 0 & o & A & I W & W & & $\mathbf{x}$ & satr tratermuts. \\
\hline 36 & 1 & o & o & 1 & o & 0 & 0 & $N$ & $\ldots$ & W & & $\mathrm{x}$ & \\
\hline 40 & I & $o$ & o & 1 & o & 0 & o & ${ }^{a} \mathrm{~N}$ & 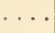 & $\cdots$ & & $x$ & ${ }^{a}$ Two sceond cousins ate nomadic. \\
\hline 40 & I & o & $\mathbf{o}$ & $\mathbf{t}$ & $\mathbf{o}$ & o & o & $a^{N}$ & 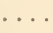 & & . & $\mathbf{x}$ & "Two first consins once removed are nomadic. \\
\hline 41 & $3+$ & o & o & $\mathbf{I}$ & $2+$ & o & o & $\mathrm{N}$ & $\because$ & ${ }^{a} \mathrm{~N}$ & . & $\mathrm{N}$ & ${ }^{a}$ A first cousin is nomadic. \\
\hline 62 & 6 & o & $\mathbf{t}$ & 1 & 3 & 1 & 0 & ${ }^{b} \mathrm{~N}$ & $1 \mathrm{WV}$ & $N$ & & ${ }^{a} \mathrm{~N}$ & $\begin{array}{l}{ }^{a} \text { Mother has no brothers; }{ }^{D} \text { probably nonadic. } \\
\text { (This family might better have been placed } \\
\text { in table } 5 . \text { ) }\end{array}$ \\
\hline 63 & 1 & o & o & 1 & $\mathbf{o}$ & o & o & $\mathrm{N}$ & I W & ${ }^{a} \mathrm{~N}$ & & $\mathbf{x}$ & ${ }^{a}$ A brother's son is nomadic. \\
\hline 63 & $\mathbf{I}$ & o & o & 1 & o & o & o & ${ }^{a} \mathrm{~N}$ & & $\cdots$ & & $\mathbf{x}$ & ${ }^{a}$ A brother's grandson is nomadic. \\
\hline 64 & 4 & o & o & 1 & $\mathbf{I}$ & o & 2 & $\mathbf{N}$ & $2 \mathrm{~W}$ & $\mathrm{~N}$ & & $\mathrm{Ne}$ & \\
\hline 65 & 7 & 3 & o & 1 & 2 & o & 1 & $N$ & $\cdots$ & $N$ & I W & $\mathrm{x}$ & \\
\hline 66 & 9 & I & 1 & 1 & 5 & o & 1 & $\mathrm{~N}$ & $1 \mathrm{~W}$ & $N$ & $\ldots$ & $N$ & \\
\hline 67 & 17 & 4 & 4 & 1 & 1 & o & 7 & N & ${ }^{a} \mathrm{~N}$ & $\cdots$ & & $x$ & ${ }^{a}$ One had a nomadic son. \\
\hline Total & 56 & 8 & 7 & 13 & 16 & $\mathrm{I}$ & II & & & & & & \\
\hline
\end{tabular}

TABLE 8.-Distribution of nomadism (W) in the offspring when the family history of each parent is litlle knoun or at least shows no other case of nomadism (class 6).

\begin{tabular}{|c|c|c|c|c|c|c|c|c|c|c|}
\hline \multirow{3}{*}{$\begin{array}{c}\text { Fam. } \\
\text { No. }\end{array}$} & \multicolumn{7}{|c|}{ Offspring. } & \multirow{3}{*}{ F. } & \multirow{3}{*}{$M$} & \multirow{3}{*}{ Remarks. } \\
\hline & & & & & $\sigma^{7}$ & & q & & & \\
\hline & & & & W. & Not= & W. & Not- & & & \\
\hline 49 & 9 & $\mathbf{I}$ & o & 4 & 3 & 0 & 1 & $\mathbf{x}$ & $\mathrm{x}$ & \\
\hline 68 & 5 & o & o & 2 & 2 & 0 & 1 & $\mathbf{N}$ & $\mathbf{N}$ & \\
\hline 69 & 9 & o & + & 1 & 2 & $o$ & 2 & $N$ & ${ }^{a} \mathrm{Pe}$ & $\begin{array}{l}{ }^{a} \text { Has depressed spells, like an uncle: also, one atunt has } \\
\text { migraine. }\end{array}$ \\
\hline 70 & 6 & o & o & 2 & o & o & $a_{4}$ & $\mathrm{~F}$ & F & ${ }^{a}$ One has migraine. \\
\hline 71 & 4 & o & $t$ & 2 & $a_{1}$ & $o$ & 0 & $A$ & $A$ & aShifted positions frequently. \\
\hline 72 & 8 & 2 & 2 & I & o & $a I_{1}$ & 2 & $\mathbf{x}$ & $\mathbf{x}$ & $\begin{array}{l}{ }^{a} \text { Wandered away from hospital; she had delusiuns of seeing } \\
\text { her father and wanted to go to him. }\end{array}$ \\
\hline 73 & 15 & 4 & 2 & 2 & $\mathbf{I}$ & o & 6 & $\mathrm{~N}$ & rp & Both parental strains show lack of inhibitions. \\
\hline 74 & 9 & 4 & o & 2 & 2 & o & 1 & $\mathrm{x}$ & $\mathbf{x}$ & \\
\hline 75 & 4 & o & o & 2 & 1 & o & $\mathbf{I}$ & $T_{p}$ & $\mathbf{x}$ & \\
\hline 76 & I & 0 & 0 & I & o & o & o & $x$ & ${ }^{a} \mathrm{Ne}$ & ${ }^{a}$ Two sisters are insine. \\
\hline 77 & 5 & o & o & 2 & 3 & o & o & $\mathrm{N}$ & $\mathrm{N}$ & \\
\hline 78 & 5 & o & o & 2 & $a_{3}$ & o & o & A & ${ }^{b} \mathrm{~N}$ & $\begin{array}{l}\text { "Two are insane; the third has an ugly temper; "a brother is } \\
\text { periodically exeited. }\end{array}$ \\
\hline 79 & 7 & I & o & 2 & 3 & o & 1 & ${ }^{b} \mathrm{~N}$ & $\mathbf{x}$ & ${ }^{a}$ Of bad stock. \\
\hline 80 & 10 & I & o & 8 & $a_{4}$ & 0 & 4 & $\mathrm{~N}$ & $N$ & ${ }^{a}$ Onc lives in Nurthern Mexico and one in Oklalsoma. \\
\hline $8 t$ & 8 & 2 & 2 & 1 & 2 & o & i & $N$ & $x$ & \\
\hline 82 & 6 & o & o & I & $a_{4}$ & o & 1 & $\mathbf{x}$ & $b_{x}$ & ${ }^{a}$ One is wild and gambles; ${ }^{b}$ one sister las headaches. \\
\hline 83 & 3 & I & I & 1 & o & o & o & $\mathbf{x}$ & $\mathrm{x}$ & \\
\hline 84 & 2 & o & o & 2 & o & o & o & $a_{A}$ & $\mathrm{x}$ & ${ }^{a} \mathrm{H}$ is wife left lim hecuuse of his drunkenness. \\
\hline
\end{tabular}


TABLE 8.-Distribution of nomadism $(W)$ in the offspring when the family history of each parent is little known or at least shows no other case of nomadism (class 6)-Continued.

\begin{tabular}{|c|c|c|c|c|c|c|c|c|c|c|}
\hline \multirow{3}{*}{$\begin{array}{l}\text { Fam. } \\
\text { No. }\end{array}$} & \multicolumn{7}{|c|}{ Offspring. } & \multirow{3}{*}{ Ii. } & \multirow{3}{*}{ M1. } & \multirow{3}{*}{ Remarks. } \\
\hline & \multirow{2}{*}{ Tot. } & \multirow[b]{2}{*}{$\mathbf{x}$. } & \multirow{2}{*}{$\begin{array}{c}\dagger \\
y g\end{array}$} & \multicolumn{2}{|c|}{$\sigma^{7}$} & \multicolumn{2}{|r|}{ q } & & & \\
\hline & & & & W. & $\begin{array}{l}\text { Not- } \\
\text { W. }\end{array}$ & W. & Not- & & & \\
\hline 85 & 7 & o & I & 2 & 3 & o & $\mathbf{I}$ & $\mathbf{E}$ & ${ }^{a} \mathrm{Ne}$ & ${ }^{a} \mathrm{~A}$ brother has dementia precox. \\
\hline 86 & 8 & 3 & $\mathbf{I}$ & I & o & o & 3 & $a_{\mathrm{N}}$ & I & ${ }^{a} \mathrm{~A}$ captain of State militia. \\
\hline 87 & $\mathbf{I}$ & o & o & $\mathbf{I}$ & o & o & o & $\mathrm{x}$ & $\mathrm{x}$ & \\
\hline 88 & 13 & 5 & 4 & 2 & 2 & o & o & $\mathbf{x}$ & $\mathbf{x}$ & \\
\hline 89 & 13 & o & 4 & 2 & o & o & 7 & ${ }^{a} \mathrm{C}$ & $\mathrm{Sx}$ & ${ }^{a}$ Part Indian; incarcerated for theft. \\
\hline 90 & $\mathbf{x}$ & o & 1 & o & o & o & o & ${ }^{a} \mathrm{~F}$ & $x$ & $\begin{array}{l}{ }^{a} \mathrm{~F} \text { and } \mathrm{M} \text { cousins; much insanity in the } \\
\text { common blood. }\end{array}$ \\
\hline 91 & 5 & $\mathbf{r}$ & $\mathbf{I}$ & $\mathbf{I}$ & o & o & 2 & A & $\mathrm{Ne}$ & \\
\hline 92 & 9 & o & $\mathbf{I}$ & 2 & 3 & o & 3 & A & $N$ & $\begin{array}{l}\text { Principal fraternity much subject to } \\
\text { "spells." }\end{array}$ \\
\hline 93 & 5 & $\mathbf{o}$ & o & 2 & I & 0 & 2 & $\mathrm{x}$ & $\mathrm{Ne}$ & \\
\hline 94 & 8 & 3 & I & I & I & 0 & 2 & A & $\mathrm{N}$ & \\
\hline 95 & I & o & 0 & I & o & 0 & o & $x$ & $T_{p}$ & \\
\hline 96 & 2 & o & 0 & I & o & I & o & $F$ & $x$ & \\
\hline 97 & 7 & 5 & o & I & I & o & o & $\mathrm{N}$ & $N$ & \\
\hline 98 & 7 & o & o & I & 2 & 0 & 4 & $N$ & $\mathrm{~N}$ & \\
\hline 99 & I & o & o & I & o & 0 & 0 & $\mathbf{x}$ & E; & \\
\hline 100 & 10 & o & 2 & I & 3 & o & 4 & $T_{p}$ & $a_{\mathrm{F}}$ & ${ }^{a}$ One of mother's brothers and the MF go \\
\hline Total & 214 & 33 & 28 & $5 \mathrm{I}$ & 47 & 2 & 53 & & & \\
\hline
\end{tabular}

\section{INHERITANCE OF THE NOMADIC TENDENCY.}

\section{HYPOTHESIS.}

The first outstanding fact that a study of the tables reveals is that nomadism is found prevailingly in the male sex. Thus in the principal fraternities of our tables there are i 68 cases of male nomadics to 15 of female nomadics. This fact leads one to formulate the hypothesis that nomadism is a sex-linked trait. Now, a simple recessive sex-linked trait fulfills the following conditions in heredity:

(I) The tendency is ordinarily traced through the maternal side; it is carried by the maternal germ-cells, though the mother may not show the trait somatically. But the tendency does show itself, usually, either in the mother's father or in the mother's mother's father, and, in the latter case, also in the mother's brothers.

(2) Half of the sons and none of the daughters derived from such a "tainted" mother married to a normal man will show the nomadic tendency.

(3) If the mother is somatically nomadic and the father not, all of the sons are nomadic.

(4) If both parents are nomadic, all of the children, both sons and daughters, are nomadic.

(5) If the father is nomadic and there are nomadic offspring, then half of the sons and half of the daughters are nomadic. 
(6) If neither parent of nomadic offspring is nomadic, half of the sons and none of the daughters are nomadic. This is the same as (2) above, for by hypothesis the mother is of nomadic stock.

(7) If the parents of nomads are unknown or slightly known it is to be expected that half of the male children and a few females will be nomadic.

\section{TEST OF THE HYPOTHESIS.}

Condition 2, which probably comprises condition 6 (and 7 in part), may be tested in tables $I, 6,7$, and 8 . From these tables we get the results as to offspring given in table 9 .

TABLE 9.

\begin{tabular}{|c|r|r|r|r|}
\hline \multirow{2}{*}{ Table. } & \multicolumn{4}{|c|}{ Offspring. } \\
\cline { 2 - 5 } & \multicolumn{2}{|c|}{ Males. } & \multicolumn{2}{c|}{ I.emales. } \\
\cline { 2 - 5 } & W. & Not-W. & W. & Not-W. \\
\hline I & 68 & 45 & I & 54 \\
6 & I & 0 & 0 & 2 \\
7 & 13 & 16 & I & 11 \\
8 & 51 & 47 & 2 & 53 \\
Total & I33 & 108 & 4 & I2O \\
\hline
\end{tabular}

Here, where "expectation" is an equality of nomadic and sedentary males, we actually get a marked excess of nomadics. 'This, however, is in accordance with a more analytical expectation. An inspection of the tables will show many families with only one son, and he is, of course, always nomadic. Now, there must be many other families of potentially nomadic sons in which the only actual son was non-nomadic. All such cases were excluded from our tables, however, for this is a study of the origin of nomads. Hence the total number of nonnomadics included in our tables must be too small, as we find is the case.

The occurrence of 4 nomadic females is also against "expectation," since, by hypothesis, these will be found only when the father is nomadic. First, it is to be observed that 2 of the 4 cases come from table 8 , where we lack details about the father as well as the mother and her stock. In the case from table I the father is wholly unknown and the fraternity is listed in that table only because of a probable nomadic tendency in the mother's stock. The case from table 7 (family 62) deserves detailed consideration. The affected daughter, a seamstress, is aged 23, is fond of out-door life, and public-spirited, but more decply interested in domestic life. At times she has a desire to roam. Her father was born in Germany in I864, came to the United States at 19 years, was in Missouri and Wisconsin, was successively mason, a general farmer, and a fruit grower, is very fond of nature and out-door sports, and a leader in public affairs. He has a brother who is a careless, carefree wanderer. 
Now in view of the facts (I) that the father emigrated shortly after adolescence from Germany to America, (2) that he changed his location in America from Missouri to Wisconsin, (3) that he changed his occupations three times, (4) that he has a love of nature and of out-doors so often associated with nomadism, and (5) that he had a brother who is a tramp, it seems probable that this case should really have been included in table 5. I leave the case in table 7 , however, in order to avoid the possible objection that I get agreement with the hypothesis by placing the cases arbitrarily in the different tables in such fashion as to secure agreement. The conclusion is, then, that there is no clear case of a nomadic daughter whose father is known to be non-nomadic.

The third criterion, that all sons of a nomadic mother are nomadic, may be tested by a reference to tables 2 and 3 . There are unfortunately only 7 fraternities to consider, comprising altogether 19 children. Concerning the sons in family 42 , we have only the brief statement "some of her (the nomadic mother's) 6 sons show it" (i.e., the wanderlust that the mother had). Whether this means that the field-worker knew only some of the sons, and that they were all nomadic, or that there were some known not to be nomadic (which is certainly not so stated), can not be decided from the statement quoted, but probably the former is the case, for the fraternity lived long ago and is only incidentally referred to. This family can not be cited as an exception. Family 44 seems to afford an exception. Of 5 sons of two "gypsy" parents, all but one are stated to have followed a business which had traveling in it. Of the exceptional son we have no data other than that he was a farmer and died unmarried. This case, too little known, should hardly be considered decisive against the hypothesis.

The next criterion is that all daughters of two nomadic parents should be nomadic. In table 3 there are 4 daughters, and all of these are clearly nomadic.

The fifth criterion-that half of the daughters and half of the sons of nomad-bearing fraternities of offspring of nomadic fathers should be nomadic - may be tested from tables 4 and 5 . The expected equality is indeed found in the sons, but not in the daughters. For there are only 7 nomadic to 20 non-nomadic, or as 1 to 3 , instead of 13.5 to 13.5 . If we examine all cases we find that in family 17 (from Stier) the fraternity is apparently not completely given; and family i 8 is from Stier's record, which was not based on field-work. In family $49 a$ we know only that one of the non-nomadic daughters always had bad nervous headaches and the other became demented in later life. Attention may be called to the great deficiency of daughters, which is in part due to the fact that many are not described at all and hence are represented in the unknown column, and it is probable that among the women of whom no description could be obtained there will be a disproportionately large number of nomadics. Considering the rarity of nomadic females 
in the population, the large proportion of nomadic females in tables 4 and 5 speaks strongly for the view that there is a single sex-linked determiner that makes for domesticity, and that only where it is absent from the germ-cells of both parents will the daughters be nomadic.

The large number of nomadic sons in tables 4 and 5 , where the father is nomadic, would seem to speak against the hypothesis that the father's germ-plasm does not influence the nomadism of the sons. But it must be remembered that our tables comprise only fraternities of offspring who show some case of nomadism. By reference to our family histories numerous cases will, however, be found where a nomadic father has no nomadic sons (e.g., families 3, 25, 29, 30 (4 children), 34, 36, 42, 61). But there is, I think, no case of a nomadic mother of more than 2 children of whom none is nomadic. Moreover, the great frequency of nomadic fathers of nomadic sons (not called for by the hypothesis) is quite certainly due to the circumstance that nomadic men are apt to marry women who either are nomadic themselves or belong to nomadic stock. The case of Borrow, who took up with the itinerant Isopel (Borrow, I85I), illustrates this tendency.

Alternative hypotheses to the one proposed above must be considered. Nomadism may be an essentially male characteristic and one which, like the beard of man, depends upon hormones elaborated by the male germ-glands. Against this hypothesis is the fact that nomadism is by no means confined to the male sex; in certain matings daughters as well as sons are nomadic. The distribution of the nomadic trait among the offspring is, then, a function of a particular mating.

The hypothesis has been urged that nomadism is less common among women than among men because it is less feasible for women to live a nomadic life. But no one who carefully examines the family histories here given, especially Nos. 53, 55, 46, 47, can seriously maintain this view. The fact that among gypsies, for example, women enter in to the life with the same inevitableness as men speaks against the hypothesis. On the other hand, the frequency of nomadic women among gypsies is easily explained by a consideration of their pedigrees. One finds on examination of such pedigrees as are published in the Journal of the Gipsy Lore Society that nomadic men and women commonly marry each other and, as our hypothesis leads us to expect, all the offspring are nomadic. Thus all the evidence supports the lypothesis that the nomadic impulse depends upon the absence of a simple sex-linked gene that "determines" domesticity. 


\section{NOMADIC OCCUPATIONS.}

The peculiar impulses of nomads lead them to choose occupations in the pursuit of which they are carried to new scenes and otherwise have satisfied their craving for travel and adventure. Among such occupations are: pioneer settler, cowboy, seaman, sailing-master, shipcook, marine, naval officer, traveler, explorer, naturalist, missionary, traveling salesman, itinerant bookseller, peddler, itinerant tinkerer and kettle mender, tramp, "beach-comber" of the South Seas, professional pedestrian, soldier (especially in times of peace), engineer, conductor, brakeman, train hand, lineman, chauffeur, stage or express driver, jockey, horse-racer. Such occupations are in contrast with clerk, factory hand, shop-keeper, domestic servant, small farmer, success in which requires sessility, stability, persistence, domesticity. Many ascribe the wandering traits often found in the first group to the nature of their occupation. Inquiry will frequently reveal the fact that the nomadic occupation has been selected because it accords with the innate tastes and impulses of the restless man.

\section{ASSOCIATION OF THE NOMADIC IMPULSE WITH PSYCHOSES.}

The first thing that strikes one in an examination of the family histories is the frequent association in the same family and even in the same individual of nomadism and various well-known aberrant nervous and mental states. Among these conditions that are extraordinarily common are: periodic psychoses, with depression and frequently suicide (e. g., Nos. 2, I 3, 19, ${ }^{2 *} 20,{ }^{8} 24,25,{ }^{6} 29,{ }^{2} 32,38,41,{ }^{3} 44,45,49,{ }^{3} 76,{ }^{2} 78$, $\left.85,{ }^{2} 89,{ }^{2} 92,{ }^{3}\right)$; fits of temper, including various explosive tempers (e. g., Nos. I $\left.3,{ }^{10} 20,{ }^{3} 24,{ }^{8} 25,,^{2} 41,{ }^{7} 54,{ }^{3} 62,{ }^{2} 73,,^{2} 95,,^{3} 98,{ }^{2} 99^{2}\right)$; migraine and periodic headaches (e.g., Nos. $3,{ }^{5} 23,{ }^{2} 42,{ }^{3} 49,58,69,80,{ }^{2} 85$, I00); epilepsy (e. g., Nos. $5,^{3}$ I I, 2 I $, 43,^{2} 50,{ }^{3} 54,{ }^{4} 65,85,99^{2}$ ); hysterical attacks (e.g., Nos. 8, 24, $\left.{ }^{3} 25,42,61,85,95\right)$; sprees (e.g., Nos. 1 2, 25, ${ }^{2}$ $\left.34,40,60,{ }^{2} 85,90,100^{2}\right)$; sexual outbreaks or general weakness of sex control (e.g., Nos. I $4,{ }^{2} 29,{ }^{2} 40,{ }^{4} 47,{ }^{2} 50,{ }^{2} 60,{ }^{3} 7 \mathrm{I},{ }^{5} 89,{ }^{5} 95^{2}$ ). These states are characterized above all by periodicity and lead to the conclusion that nomadism is a trait that belongs especially to families that are subject to periodic emotional disturbances.

This association in the same family of the nomadic impulse and numerous other periodic disturbances throws much new light, I think, on the significance of the nomadic impulse. The old view ascribes the impulse now to the epilepsy, again to the hysteria, and still again to the depression or to the sexual outburst. That is the meaning of the classifications, given at the outset of this paper, of the different sorts of fugues. But the family histories show that epilepsy, hysteria, depression, etc., may occur without the nomadic impulse, as the

*The exponent expresses the number of individuals in the history that shows the trait. 
nomadic impulse, in turn, may occur without the other psychoses. The student of epilepsy, finding nomadism often associated with it, concludes that nomadism is a symptom of epilepsy, or is sometimes "caused by" epilepsy. The student of hysteria is struck by cases of nomadism-occurring as "ambulatory automatism" - and ascribes them to hysteria. A student of the depressed similarly finds in that state the cause of the wanderings so often associated with it. Still other students consider the wanderings as incomplete inanifestations of epilepsy, hysteria, depression, as the case may be. Others classify them under the vague term "equivalents." The new light brought by our studies is this: 'The nomadic impulse is, in all the cases, one and the same unit character. Nomads, of all kinds, have a special racial traitare, in a proper sense, members of the nomadic race. 'This trait is the absence of the germinal determiner that makes for sedentariness, stability, domesticity. Under the influence of the mores-or social pressure-the nomadic impulse is often repressed for a considerable time, but periodically - due to the same sort of internal tension that in other individuals (especially other members of their families) leads to epileptic, hysteric, depressive, and sexual outbreaks - they are unable to inhibit the impulse and it breaks out. The individual becomes more and more restless as his inhibitions grow less and less effective, and finally he gocs off. It is probable that, without the periodic paralysis of the inhibitions, the nomadic tendency will generally reveal itself in a minor form of restlessness, such as our family histories frequently show. But nomadism is so often associated with other sorts of periodic behavior because, for extreme exhibitions of nomadism, it is not enough that the intelligent nomad should be without the sedentary trait; on the contrary, his inhibitions must be periodically paralyzed; he must belong also to a race of periodics. In such a race of periodics the nomadic impulse shows itself in fullest and most typical form.

One other class of nomads must be considered - the one that belongs to strains showing feeble-mindedness and dementia. Such nomads usually lack a normal development of the inhibitory mechanism, and in such the nomadism is less apt to be of the explosive type. To this class belongs many typical rolling-stones or ne'er-do-wells, some tramps, the gypsies, and the other nomadic tribes. Examples of such are seen in our family histories Nos. 4, 22, 29, 37, 44, 48, 50, 63, 66; also I 3.20 . $24,78,86,100$. These cases differ from those described in the last paragraph only in this, that the inhibitory mechanism is so poorly developed that the nomadic tendency shows itself without waiting, as it were, for the paralysis of the inhibitions. The relation between this class and the other is much the same as between the steady drinker and the dipsomaniac. There is so little resistance to be overconne in this latter case that one can no longer speak of an overwhelming inipulse. Representatives of this class roam about as naïvely as the chimpanzee or young children do. 
We see, then, that all cases of nomadism can be ascribed to one fundamental cause - that those who show the trait belong to the nomadic race. In addition, since the more intelligent representatives of that race are able in a measure under ordinary circumstances to inhibit their impulses, we find that with such people the unstable, wandering impulse is apt to be associated with a periodic disturbance which renders inoperative the inhibitory machinery. Of such disturbance, epileptic, hysteric, dipsomanic, erotic, depressive attacks are other symptoms; they are frequent concomitants, but not the fundamental cause, of nomadic impulses. They merely permit the nomadic impulses to appear.

\section{SUMMARY.}

( $\mathrm{I}$ ) The wandering instinct is a fundamental human instinct, which is, however, typically inhibited in intelligent adults of civilized peoples.

(2) Nomadism is probably a sex-linked recessive monohybrid trait.

(3) Sons are nomadic only when their mothers belong to nomadic stock.

(4) Daughters are nomadic only when the mother belongs to such stock and the father is actually nomadic.

(5) When both parents are nomadic expectation is that all children will be.

(6) The nomadic impulse frequently occurs in families showing various kinds of periodic behavior, such as depression, migraine, epilepsy, and hysteria. It is concluded that these periodic states are not the true cause of nomadism, but rather that, for the better inhibited part of the community, the nomadic tendency is released in the periodic state which paralyzes the inhibitions. The feeble-minded and demented may wander without going into a periodic state. The periodic psychoses are frequent concomitants, but not the fundamental cause, of nomadic impulses. They merely permit the nomadic impulses to appear.

\section{LITERATURE CITED.}

Borrow, G. I851. Lavengro: The Scholar-the Gipsy-the Priest. 3 vols. DENIKER, J. I906. The Races of Man. London and New York, xxiii+6i I pp.

Garner, R. L. I89o. Apes and Monkeys: Their life and language. Boston, xiii +297 pp. Gaster, M. I9IO. Gipsies. Encyclopedia Britannica, xir edition, vol. xir, pp. 31-43. HaLl, G. S. 1904. Adolescence. New York: Appleton, 2 vols., $x x+589$, vi +784 pp. Hamel, and R. Meunier. 1897. Vagabondage et folie. Congr. de med. mental, Toulouse. Jofrroy, A. and R. Durouy. I909. Fugues et Vagabondage. Ettude clinique et psychologique, Paris, $368 \mathrm{pp}$.

Kingsi,EY, J. T. I 885 . The Standard Natural History, vol. vi. Boston, xi+ 478 pp.

KLINE, L. W. I 898 . The Migratory Impulse $v s$. Love of Home. Am. Jour. Psych., X, $1-81$. MEUnier, R. 1908. Les vagabonds et le vagabondage. Rev. mod. de med. et de chir.

PARENT, V. 1909. Les fugues en psychiatrie, $\mathrm{xix}^{\mathrm{me}}$ Congr. des aliénistes et neurolgists de France, $145 \mathrm{pp}$.

STIER, E. I913. Wandertrieb und pathologisches Fortlaufen bei Kindern. Samml. zwangl. Abh. z. Neuro- und Psychopath. des Kindersalters, I Bd., Heft I-3, 135 pp. 


\section{APPENDIX.}

\section{ABSTRACTS OF 100 FAMILY HISTORIES OF NOMADS.}

(1) 'The propositus is a boy, now I 3 years old, whose career began when he was 3 years old. He then walked to the railroad, pushed the turnstile, boarded the train, and rode out 12 miles before he was discovered by the conductor. He has run away many limes since, despite the best of home influences. He would stay away from home nights; and from the institution where he was placerl he ran away i 3 times, and scrubbed in the "movies" to get money for food. His mother used to make Saturday a treat day, take a violin lesson with him downtown, and spend the afternoon in the public library, which he much enjoyed, but he would slip away from her and be gone until midnight. His parents exhausted every resource to help him. They took him to Europe when his father went abroad to study. All efforts were witlout avail. He lies and steals without reason, contracts debts for his father to pay, finally: committed a burglary and was sent to a reformatory. Sib: A 6-year-old brother is normal in every way-truth-telling and lovable. An only sister died at 2 years of tuberculosis meningitis.

The father is an intelligent physician, healthy and slender. His father was a Methodist preacher.

The mother is a small woman who had St. Vitus dance at i 2 years, was able to study only intermittently, is subject to frequent headaches. Has inusical ability, plays the violin. Has two sisters of good repute.

The mother's father was a Western desperado; drank hard at times and was involved in murder, etc. 'The patient does not know of this grandparent. Of the 3 grandchildren of this man the patient is the only one affected.

The mother's mother was a "very good woman." (3: 116.)

(2) The principal fraternity comprises 4 persons. Of the 2 males the elder is dissipated and good for nothing. At $I_{7}$ he ran away, joined the navy, deserled, and then joined one of the worst gangs in the city, and the younger, at 12 years, is very unmanageable. 'The elder of the 2 girls has been accustonied to run the streets and play truant, she is extraordinarily erotic and has been placel under State care; the younger sister is wild, highly erotic, and of a sensitive, shut-in disposition.

'The father, who is nervous, excitable, and hysterical, connes of a fine family of high culture. 'The father's father was captain in the Civil War; one of his brothers was epileptic, another went insane, and a sister, of brilliant intellect, had a high temper and deserted two husbands in succession.

The mother, who was of inferior stock to her husband, was very erotic. Her sister had manic-depressive attacks and loved excitement. Of her 3 brothers the eldest is a hard-working, honest man; he removed to Texus, but returned home on account of his health. 'The second is very alcololic. 'The third is of good repute; he lives with his parents "but is ac'ay most of the lime."

The mother's mother is of a helpless, complaining sort. She has a fecbleminded sister who is subject to epileptic fits and had, illeginately, a son who, after he grew up, went to sea.

The impulse to run away and join the navy seen in the boy of the principal fraternity has probably come from the mother's side, as a first cousin of this mother similarly went to sea. $\quad(9: 540$. 
(3) Patient, born i 885 , New Hampshire. At 2 years he had convulsions. As a child was very stubborn; if crossed became angry and screamed. $\mathrm{He}$ first left home at the age of about $I 7$, harvesting in the summertime, working his way from place to place. He has tramped over a good part of the United States, picking oranges in Florida and harvesting in the Middle West. He returned home for the winter and spent it in hunting and doing odd jobs. He is thrifty. In May I9I I he went off as usual, but came back in July and had no money with him, which was most unusual. He soon left, but returned in a week and said that he could not seem to work. In the fall of ig I he began to have headaches. Began to have ideas of superiority and would fly into a frenzy every time he was not given money. Made threats; ideas of grandeur increased; he had hallucinations. Sibs: $I-\sigma^{7}$ works for a farmer, in New Hampshire. 2- $\sigma^{\lambda}$, when 6 years old had a convulsion in school. Has been in the U.S. Navy since May I908, on cruiser California. Has a roving disposition but, together with the two younger brothers, was easy to manage as a child and thoughtful for his mother. $3-\sigma^{7}$, born 1889 , works on a farm.

Father.-Natural disposition is gentle and pleasant. He began to drink excessively some time before the birth of patient. When intoxicated becomes ugly and stubborn. His wife compares patient's natural disposition with that of his father when drunk. Father's sister.-born i 870 . Following her husband's death she had nervous prostration. She is troubled with "neuralgic headaches" and is rather frail; is a remarkably fine-looking woman, cultured and intelligent; is active in the dramatic productions of a local woman's club.

Father's father. - an unusually kind and pleasant man, worked for the railroad; was killed in an accident at the age of 45 . He and his brother had neuralgic headaches. Of his two sisters nothing is known.

Father's mother.--born 1846 , is a very nervous, high-strung woman. Sibs: $\mathrm{I}-q$, unknown; $2-q$ troubled with neuralgic headaches; $3^{-q}$ given to worry; $4^{-}$O , died of Bright's disease; $5^{-}+$was sensitive, apt to be pessimistic and to worry over little things, but her disposition was even and kind and generous; $6-0^{7}$, living in New Hampshire, has a daughter who is inclined to worry; $7-\sigma^{7}$, died of heart disease.

Mother.-Brought up by friends until 8 or Io, when her father took her to keep house for him, but because of hard work and isolation she was later sent to live with someone else. She is a quiet woman who takes things as they come without whining. Has a good-looking, intelligent face and a refined speech and manner. Her only sib is her brother (born r863), who still lives in his native State.

Mother's father.-Had his ro-year-old daughter keep house for him. Often left her alone in the house all night or till very late. He had roving tendencieswould go West and stay a year or so and return and then go again and return. Of three sisters all live nearby. Of three brothers one had a roving disposition, one went west to one of the Dakotas, and one is dead.

Mother's mother. - Was of a gentle disposition. She died of tuberculosis after the birth of her second child. Sibs: $1-\sigma^{7}$, farmer, had 3 children, none nomadic. 2- , normal, had one daughter, unknown. $3^{-0}$, deteriorated, had hallucinations; all three children died young. $4^{-}$으, had a bad temper; has one son who lives west. $5^{-}$, , easy-going; had 2 children who died in infancy, 2 other daughters of whom little is known, and 2 sons; one has a roving disposition, moved back and forth, east and west. 6- 9 , little known.

Mother's mother's father.—Was a bear-hunter of some note; was called Bthe Bear Hunter. (I I : I 72.)

(4) Propositus is a restless visionary. He has always been shifting from one position to another. Left home some monihs ago saying he was going IVest; has 
not been heard from since. Sibs: $\mathbf{I}-9$, died $1+$ years. $2-\sigma^{7}$, died in infancy. $3-\sigma^{7}$ works in a factory; is getting divorced. $4-\sigma^{7}$ has a roving disposition; is a nurse and companion; accompanies various patients on their trips for health. $5^{-\%}$ has long been lawless and violent in her actions; she ran away from home while in a commercial school; had been there only a few weeks when she got the principal to refund her tuition, which had been paid in advance; with this money she went to $\mathrm{L}$ - and became a telephone operator, later she ran away again to marry, and since her marriage she has run away; she loses her temper.

Father, unknown.

Mother, unknown. Sibs: I- $\sigma^{7}$, unknown; $2-\sigma^{7}$, drowned when 7 years old.

Mother's father.-Was a stage-driver between Salem and Boston and kept a tavern or "roadhouse" in what is now an outskirt of $\mathrm{L}$ _- Some of his descendants suggest that the wanderlust and frequently erratic character of his descendants comes through this ancestor.

Mother's mother, unknown. (12: I77.)

(5) Propositus, o7, born I89I; began to have epileptic convulsions at 18 months and became worse after 7 years. Committed to epileptic hospital because "he would go everywhere when at home and was indanger of being injured." Sibs: $1-\sigma^{7}$, born 1886 , has been away from home, in the army (?) until a few months ago; $2,3^{-\sigma^{7}} \sigma^{7}$, died in infancy; $4^{-}+$, died at 3 years; $5^{-7}$, born 1900 , is nervous, became badly burned one fourth of July.

Father, born 1860 , drank very hard and was nervous "in consequence." Sibs: $1-q$, died at 21 years of epilepsy. $2-\sigma^{7}$, born 1878 , has no steady $\mathrm{cm}$ ployment, is a hard drinker, and unmarried. $3-\sigma^{7}$ does not drink. $4-\sigma^{\top}$ drinks habitually; employed by the city.

Father's father. Born in Ireland, died in Massachusetts, fairly temperate.

Father's mother. Said to have been normal.

Mother, born 1867 , is intelligent and pleasant, makes a good appearance. Sibs: $\mathrm{I}-\mathrm{O}^{7}$ is something of a wanderer and has not been heard of for some years. $2-\sigma^{7}$, born about 1857 , is West somewhere, address not known. 3-o, always well.

Mother's father. Born I 829, died I 892 of tuberculosis.

Mother's mother. Born in Ireland, 1829, had epilepsy. (18: 199; III 5.)

(6) Propositus, born I880 in Canada, "a perfect whirlwind in his school work," the smartest boy in his classes at school. At 12 or I 3 ycars he began to act queerly and became very quiet, selected bad companions, and ran away from home and has not let his parents know where he is since (was for a while in Port Arthur, Canada); he was always subject to sick headaches. Sib: 1- $\sigma^{7}$, died at 19 years.

Father.-A very nervous man and very delicate; died from an overdose of poison.

Mother.-Well educated; had a fall; sent to hospital on account of insanity, and now an epileptic; nearly killed her nephew by choking him. Sibs: $1-\phi^{\prime}$, died in infancy. 2- $\sigma^{7}$, living on a ranch in Montana. $3^{-9}$, died, 7 montlis. $4^{-\sigma^{7}}$ died, 8 years, tuberculosis. $5-\sigma^{7}$, born 1858 , in U.S. A rmy and wounded twice in Spanish-American war; died of tuberculosis. 6-o, died in childbirth. $7-\sigma^{7}$, normal, edgeman in sawmill in Canada. 8- $\sigma^{7}$, a teamster and millwright in Wisconsin. 9- $\sigma^{7}$, lives in Minnesota. 1o- 0 , unknown.

Mother's father.-Of normal mentality, crippled with rheumatism.

Mother's father's father and Mother's father's mother.-Unknown.

Mother's mother.-Normal. (23:185; IV 22).

(7) The principal fraternity comprises 5 sons, "all wild and unmanageable." They were either cared for by organized charity or sent to a truant school. 
Some of them have gone into the navy and others have drifted away; they are considered worthless.

The father was drowned ro years ago and nothing is known about his characteristics.

The mother was a drunkard and sexually immoral. She left home saying she was about to take passage for Ireland. A few weeks later a body was found which was considered hers. She had 4 brothers; I died young, I died at 45 years, having been a hard drinker; another was alcoholic and an indifferent workman, who returned to Ireland once for a period of 7 years and then came back to America. The fourth is rather restless and has crossed the Atlantic 21 times seeking to improve his condition; his 3 surviving children are all doing low-grade work with fair satisfaction. Of the two sisters of the mother one was alcoholic and $S x$, and the other with her husband spends all they can get or beg for drink and does not care for her children.

Of the mother's parents it is known only that "both drank hard."

Here there is clear evidence that the restless traits of the principal fraternity are found also in the mother's strain. (24:17I.)

(8) In a fraternity of 4 is a man of 37 years who is dignified, sober, and intelligent. He has a wandering tendency; he went to the Philippine war and has traveled widely; is now a chauffeur; also a younger brother, badly treated at home, left at an early age, worked in a livery, and during the summer went freight riding, working now and then and stealing food from the farmers' gardens. Another brother left home early and has done well; he hates liquor. Thus 2 out of 3 male members of this fraternity have a wandering tendency. The only girl, now 26 years of age, has always been subject to hysterical attacks and is a gross $S x$ offender.

The father of the foregoing fraternity now lives in a public house, where he drives for the superintendent; has lost all interest in his family. His sister is quiet and respectable.

The mother is impulsive, emotional, and imaginative; is living with a paramour. One of her brothers went away into the navy, deserting his wife; the other brother came to America, returned to England, and has not been heard from since. 'The mother's father is unknown.

Here the nomadism of the brothers of the patient can be traced through the maternal line, appearing in the mother's brothers. (26:74.)

(9) Propositus, $\sigma^{7}$, born in Pennsylvania, I863, does not use alcohol to excess; is a reliable, respectable man. He has always roamed around until recently; has worked in different places in the West, East, and in Canada. No children. Sibs: $1-0^{7}$, born 1865 and died 1892 , was a machinist and single. $2-9$, born I866, had fits with loss of consciousness; showed symptoms of dementia precox.

Father.-A man of loose morals and a heavy drinker. One brother was an idiot and one sister a sex offender.

Father's parents unknown.

Mother.-Born I839; of bad moral reputation; was repeatedly admitted to State hospital with delusions (diagnosis of mania).

Mother's father.-Born in Ireland; had a gay, wild temperament which led him to desert the life of a priest, for which his parents had destined him, and go to America. Here he married in Pennsylvania, dirank, and was very inmoral; did some work at law, though never admitted to the bar. Tried farming, but found it distasteful. When last heard of he was in Nevada; it is not known whether he is still alive.

Mother's mother.-Probably feeble-minded. (28:816; IV 4.) 
(10) 'There are 4 in the patient's mother's fraternity. 'The only male, "reared in a respectable household, ran away at I 6 and eventually enlisied in the navy." He got into a fist-fight with a fellow-sailor and was imprisoned. He married in Cuba and had a daughter. Planned to marry bigamously on his last furlough. Of the 3 females of this fraternity, one is the mother. After her father's death she ran the streets at 12 with her mother's sister, stole, and was $S x$. 'The second was placed out in a good home, but left eventually to work in the factory; has fits of absent-mindedness; her 6-year-old son is restless and 11oisy in lis playing. 'The third is apparently normal.

'The mother's falher, a miner, is regarded as lionest and industrious. All 4 of his known sisters are $S x$, the only brother a drunkard and formerly $S x$.

The mother's mother "was $S x$; died from blood-poison." Of her 2 brothers one was married to several women at one time; became convicted of sin and went about preaching. The other brother secmed childish, ran off with another man's wife and they beg and forage together. One of the two sisters had clubfeet. The other has fits of absent-mindedness, and is easily angered. 'The mother's mother's father was "ignorant, poor, and lionest." 'The mother's mother's mother "was always dancing and singing."

In this case the nomadic tendency of the mother's brother seems to come through the maternal side, being seen in the peripatetic preaching of one of the brothers of the mother's mother and the tramp-like behavior of the other brother. Nothing critical is known about the behavior of the mother's - mother's father. (34:38.)

(11) Propositus, born 1895 , in Missouri, is (1914) a wanderer and has left home repeatedly and been away for months al a time, returning home for rest and clothes, then he goes away again; works some, but does not save or provicle for the future - a disobedient boy. Since leaving school in the fourth grade lie has done odd jobs in stores, factories, and restaurants. He does not like restraint but wants to do things his own way. Smokes a pipe and cigarettes, drinks whisky, and has used cocaine considerably. Is kind and generous and does not provide for himself; is easily persuaded by people who flatter him. Is irregular and uncertain in his habits, does not like to stay in one place long; likes to bum and tramp around to see the world. Is careless about his clothes, but likes commendation; tries to make a good impression on strangers; is a liar, a thief, and a drunkard. Has flat feet, crooked toes, crooked spine, and one shoulder is higher than the other. Sibs: $1-\sigma^{7}$, born 1894 , is now in the third year of high school and has a preference for mechanical drawing, oratory, political economy, history, and Ënglish; works in stores and factories during his vacations; has always been well, except for a spasm during inflammation of ear. He is studious and regular in his habits, very orderly and systematic, and neat in dress; earns his own expenses at school; is popular with lis classmates, honest, industrious, very positive in his statements, inclined to be arbitrary and commanding, but he has good self-control. He is an excellent reasoner and good debater, takes great pains to prepare for coming events, recognizes conventionalities, is punctual, has a persevering and pleasant personality, and wants to go to the university. Has crooked toes. $2-q$, died at 7 months of pnetmonia following exposure. $3-9$, born $1901,110 w(1914)$ in sixth primary grade, does best in arithmetic, music, granmar, and household work; has been well, except for an attack of malaria and diphtheria. Likes poetry, music, and literature, reads many books, magazines, and newspapers; is sociable, hospitable, and a good entertainer; is a good judge of human nature and easily detects shams; is loving, tender, and kind, likes to help people; is studious and desirous of improving; lias a pleasing personality 
and reading is a favorite pursuit. She writes good compositions and stories, recites poetry, and has a good memory; has large feet. 4 to 7 , $q$ \% , born I903-I9I3, all apparently normal.

Father.-Born, Ontario, Canada, I 868, educated for a year in college, then in business college; especially interested in sociology and is a social worker. Is impulsive, quick to think and act, persevering, conscientious and secretive, and shows a mixture of caution and impetuosity. Is a good judge of human nature, enjoys intellectual conversation; makes and retains friends easily; is thorough in his work and inclined to fret and worry because things do not move fast enough; is combative, quick-tempered, and fond of commendation, but easily detects and despises flattery; is a constant smoker, but does not drink liquor. Has crooked toes. Sibs: $\mathrm{I}-\sigma^{-7}$ is a good manager, successful in business, very sociable; two others died young.

Father's father.- Born in Ireland, i 824, a farmer and later a stock-dealer and market-man. I oved home life; kind, gentle, industrious, honest, conscientious, generous, and gave too much credit in business; of even temperament, seldom displayed much temper; seldom would openly resent an insult. Had good business ability. Drank a little, but not to intoxication. Smoked and chewed tobacco.

Father's mothcr.-Born in Canada, I826, literary, and read many books; very thorough in her work. A good "mixer," very sociable, made home pleasant; a good judge of human nature; constant at church and prayerful, tactful, and diplomatic. High temper when aroused in anger; would retaliate for an o injury.

Mother-Born in England, I870, educated through the fourth grade in primary school; subject to sick headache with nausea. Likes beautiful things, clothes, furniture, pictures, etc.; is incompetent in money matters. Is poetical and reticent; dislikes fancy work, but is a good cook. Generally of a good disposition, she is sometimes sarcastic and cutting in criticism, loves and hates strongly, but does not cultivate hatred. Is not very much given to social intercourse with neighbors. Has crooked toes like her father. Sibs: $1-\sigma^{7}$, born 1860 , a good manager; crooked toes. $2-\sigma^{7}$, born 1858 , a machinist, foreman in a shop, regular in his habits. $3 \sigma^{7}$, born 1865 , died at 22 years, liked music; was generous; traveled around on frcight trains.

Mother's father.-Born in England, i 836; had a limited education. Was an inveterate smoker, did not drink to excess, was slow and easy-going, very patient under injustice, a lover of home who seldom went to public ineetings, and did not easily make new friends.

Mother's mother.-Born in England, I837; was illiterate; had epileptic fits and died in one at the age of 73 years. Kind-hearted and philanthropic, industrious, energetic, easily irritated, very frugal in small matters and extravagant in important financial affairs, had poor business ability; was deceptive, untruthful, very vain, suspicious in small things, self-sacrificing for her family. Liked strong drink, became intoxicated sometimes; associated with other men than her husband. (Gra-r.)

(12) We begin with the patient's half-brother. He is feeble-minded. Placed in an institution he ran away and has becn a wanderer ever since; he seldon sticks to a job for more than a day or two and then goes to another locality; he is also very alcoholic. His brother is of good disposition and fine appearance; he stutters.

Father.-Normal intellectually, and moral.

Mother.-Was of a strong physique, good-looking, intelligent, and with common-sense in some directions. But she has had an uncontrollable temper 
and in her own household was rough in manner, profane, and, in her fits of temper, cruel. Also she lacked judgment in spending money; spent much on photographs, carriage-rides, and theaters for herself and skimped the family. By an intelligent but $S x$ man she had the violent and $S_{x}$ patient and another daughter just like her. Also a more normal daughter of 13 and a defective son. The mother had a feeble-minded brother.

Mother's father.-Was in the army and deserted, changing his name; he went on sprees; was strong, industrious, and could read and write; drawled lis words and was aphasic before his death. He first married a woman about whom it is known only that she already had an illegimate child, and had by her a son who was reckless, wild, and alcoholic, married, deserted his wife, wandered to the Pacific Coast, and settled among some cowboys in Texas, where he died. 'The mother's father had 2 brothers, of whom one was epileplic and one feeble-minded. There were also 5 sisters, of whom one went insane after her husband's death, one married a drunkard, and the others are lost sight of $(36: 187$.

(13) Propositus, $\sigma^{7}$, born I 878 ; as child was seclusive, stubborn, unambitious, very emotional, crying easily, grew more solitary. At i 7 years thought someone was trying to injure him. Walked from Springfield to II artford, Connecticut, in order to avoid enemies, but returned, as he found enemies there. Now in State hospital with dementia precox. Sibs: $1-9$, born i871, violent temper, impulsive, truthful, independent. $2-\sigma^{7}$, born 1872 , quick-tempered, irritable, quarrelsome, traded horses, drinks moderately. 3-q, patient at State hospital, stubborn, quarrelsome, acute mania. $4^{-9}$, seclusive, quick-tempered, wilful, in State hospital with dementia precox, now lives on farm in bad surroundings. 5-q, quick-tempered, moral; one of her sons is a weak character, easily influenced, does not work in one position long. $6-0^{7}$, born 1879 , dishonest, cunning, irritable, " a rogue." $7^{-\%}$, seclusive, irritable, quick-tempered, a good housekeeper.

Father.-Shiftless, irresponsible, immoral, intemperate, altogetler worthless, luas a streak of cunning, dishonest in business, stole chickens, has a violent temper. Sibs: $1-q$, born I855, disagreeable, stubborn, hateful, immoral. $2-q$, died at 20 years. $3-q$, died at 20 years of tuberculosis. $t^{-\sigma}$, died at 26 years of tuberculosis. $5-\sigma^{7}$, died at 26 years of tuberculosis. 6 , died in infancy. $7-q$, died at $1+$ years of tuberculosis. $S-q$, seclusive, sensitive, now in hospital with dementia precox. 9- $\sigma^{7}$, furtive, temper quick and uncontrolled, immoral, excessively alcolıolic.

Father's father.- Surgeon in the Civil War, had a disagreeable disposition, and quick, fiery temper.

Falher's mother.-Jealous, emotionally unstable; at childbirth temporarily insane.

Mother.-Jealous, quick-tempered, weak, fmally divorced. Sibs: 1-ণ", died in infancy. $2-\sigma^{7}$, died at 3 years. $3-\sigma^{7}$, born in Ireland, came to United States, said to have had an crratic, wandering disposition, went to. Monlunu, and has not been heard from since. $4^{-}+$, born $1 \$_{33}$, admitted to State liospital, 1863, 1875, 1879, "inclined 10 wander aw'ay"; ind hallucinations of hearing, destructive, apt to be violent toward other patients; died demented, iss 3 .

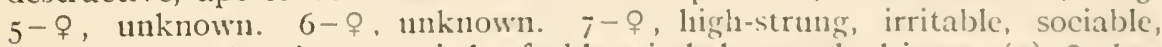
loquacious, and active; married a fecble-minded man; liad issue: (a) \& , las dementia precox, with lallucinations and delusions of persecution; $(b)$ \& unknown. 8-o , irritable, scelusive, later becance depressed and sad; by a man who was seclusive, a good worker, and a clriuker, she liad 7 children: (a) $\sigma^{7}$, irritable, alcoholic, self-controlled, steady worker, but without interest 
in work, at present a wood-cutter; (b) $\sigma^{7}$, shiftless, irritable, inefficient; (c) o , high-strung, irritable, suspicious, fault-finding, seclusive, discontented; (d) $\%$, went West with husband, no details available; $(e) \sigma^{7}$, irritable, shiftless, died; $(g) o^{7}$, seclusive, active, moral, quick-tempered.

Mother's father and mother both born in Ireland; no other data. (4I: I72; IV I27.)

(14) Propositus, $0^{7}$, born 1885 ; at the age of 17 lost an eye in a steelsmelting establishment and went West to his grandparents. Placed by them in an agricultural college, he ran up debts and disappeared. After 5 years he turned up again, destitute, having worked his way through Texas, California, Washington, Oregon, and the mountains, often riding on freight-cars or walking ties. He was given work on his grandfather's farm, but staid only a few months. He is a jolly, likeable fellow, good-natured and good-looking; has a hasty temper; is a spendthrift, untrustworthy. His one great passion is for music; has an unusually beautiful tenor roice and plays almost any musical instrument. Sibs: $1-q$, very capable but hard and selfish; $2-q$, inarried a ne'er-do-well.

Father.-A builder and mechanic. A man of coarse appetites, low and brutal passions, hard and selfish; a sexual offender who almost ruined his own daughters and nearly killed his wife for her interference. Sib: I - $q$, lived after her marriage in the same city; now in a "home."

Father's father.-A man of unusual mental powers, a student of law, and wellread generally. Was renowned for his wit, his vanity, his stories, and his varied learning.

Father's mother.-A notorious liar, mean and underhanded, contemptible, enjoyed causing suffering in others, had a violent temper, and was always restless and discontented. She was sexually uncontrolled, and it is thought that her children are not all her husband's.

Mother.-An effective woman who, after having left her husband, brought up all her 3 children. Sibs: I $-\sigma^{7}$, went to North Dakota as soon as he finished college. 2- $\sigma^{7}$, went to the Civil War. 3- $\sigma^{7}$, died at $2 \mathrm{I}$, planned "journeys" all his life.

Mother's father.-A pioneer in Western New York, a canal-boat captain, a dreamer, yet not impractical. (Ami.-1.)

(15) Propositus, $\sigma^{7}$, a student in medicine, is an introspective, reticent youth who hates social life. He is extremely fond of travel, of ships, and the sea. His "business ability is nil." Sibs: $I-\sigma^{7}$, a student in college, hates travel, but is fond of aquatic sports; he has excellent executive ability and a very social disposition. $2-q$ is fond of social activity.

Father.-Has great business ability and power of leadership. He is not introspective, stammers badly, and is passionately fond of travel and of the sea. Likes marine sports. Sibs: No evidence of $I V$ in two sisters or in either of their 2 sons or in the $\mathrm{I}$ brother.

Father's father.-A ship-owner; a retiring, self-contained, introspective man of good business ability.

Father's mother.- - Had a very social disposition and was not given to deep reflection.

Father's mother's father.-Was a ship-captain.

Mother.-A retiring, reflective woman with a fear of ships and the sea. There is no statement made that either of her sisters showed wancierlust.

Mother's father.-An erratic man of marked inventive ability, "evinced much wanderlust and traveled wide, especially at sea." His business ability was very slight. 
Mother's mother.-Was a "retiring woman of cogitative, poetical nature." Mother's mother's father.-A slip-builder. (Cor-3.)

(16) Propositus, $\sigma^{7}$, born in Georgia, I 875 ; formerly a suilor, then superintendent in ice-factory; now mechanical enrineer; interester in scientific farming. Sibs: I- $\sigma^{7}$, died in infancy. $2 \sigma^{7}$, born iS7S, traicling sulesman. 3- $\sigma^{7}$, sailor, railroad man. $\quad+\sigma^{7}$, formerly a sailor, then grocer's clert, tinen on railroad. $5^{-} \sigma^{x}$, bookkeeper, grocer, drug clerk, physician, a good manager. $6-\%$, dissatisfied disposition. $7-\sigma^{7}$, railroading.

Father.-Born in Georgia, $18+8$, a tinker, an inspector, and later a farmer; slow and solemn. Sibs: $1-q$, died in infancy. 2- $\sigma^{2}$, unknown. $3-q$, unknown. $4-0^{7}$, minister, studious. 6 others unknown.

Father's father.-Sawmill and grist owner; home-lover; religious; liked meclianical work.

Father's mother.-Homekeeper and church-lover.

Mother.-Dissatisfied disposition; dislikes poverty and work. Sibs: $1-\sigma$, left home and has not been heard of in Io years; 3 sisters; and 2 brothers (both now dead).

Mother's father.-Navigator, then merchant, millman, farmer.

Mother's mother.-Energetic, economical. (Qua-I.)

(17) In Stier's (1913, p. I06) case of Karl B, a nomadic boy had a normal father and mother, but the brother of the mother was constantly rumning away, even as a small boy, and remained away for days and weeks at a time; was in military service, deserted, fled to Sweden. The father of the mother was first a field seigeant, then head of the police guard, then became a tinkerer (itinerant), finally becane alcoholic, degenerated, and died blind.

(18) In Stier's (1913, p. IOS) case of Firnest F, the father was somewhat nervous and formerly drank a little; the mother and her 2 sisters are normal. A brother of the mother began at the age of Io years to run about, even at night, many times for a week at a time, when he has begged and stolen. Now, at $2+$ years of age, has quieted down. 'Two other brothers are normal. The father of the mother travels through the country with artists.

(19) Propositus, $0^{x}$, born 1964 , in Illinois. Had a sunstroke at 16 years, after which his mind was somewhat affected. He had led an erratic life for years, with frequent periods of excitement. In the summertime he would travel about the country. During these attacks he probably drank heavily; they lasted for 2 to 3 montlis. At the time of commitment to a Massachusetts State hospital he was an advertising agent. He escaped from the hospital twice. In 1880 he was inmate of an Illinois State hospital. The record states: "has been wandering around the country drinking, smoking, and sprecing for a month; a year later he entered the hospital again." For a month before commitment was wandering about, said he was a detective, and has delusions as to his great powers. Sibs: $1-q$, born 1865 , in Illinois; highly sexed; promiscuous before marriage; at 77 years had a nervous breakdown; has been at hospital for nervous persons three or four times, is classified as a manicdepressive. $2-\sigma^{7}$, highly sexed, dresses loudly, probably drinks. $3-\sigma^{7}$, born I 878 , harmless. 'Three other sibs died in infancy.

Father-Died at 70 years of nephritis; is said to lave gambled, drank heavily, and to have led a fast and loose life; divoreed from his wife; married a cheap "fortune-teller," with whom he had lived before his marriage. Sibs: $\mathbf{1}-\sigma^{7}$ has average health; $2-q$ living in Paris, France.

Father's father and mother.-Little known. 
Mother.-A well-balanced woman who has usually enjoyed good health. Sibs: $1-9$, no mental trouble. $2-\sigma^{7}$, became childish before death. $3^{-}+$, at I9 spent 3 months in an asylum; after an attack of typhoid fever she was left mentally disturbed and was sent to a State hospital. $4-0$, strong and healthy. $5^{-9}$, died at 72 in California. $6-9$, mentally and physically normal. $7-0^{7}$, at 5 years he ran away from home and joined the army, drank heavily, becoming ugly but not intoxicated; said to have been a very peculiar man; never talked about his family; did not know if they were living or their whereabouts when asked. 8- $0^{7}$, born I849, joined the army, was thrown from a horse, mental trouble followed, and he was eventually sent to a State hospital; on admission his occupation is recorded as sailor; he was imprisoned for theft; later in State hospital, occupation, cigar-maker; also in work-house, and again in hospital, where he died; diagnosis, dementia. 2 other sibs died in infancy.

MIother's father.-A high-strung nature, intemperate, but not strikingly abnormal mentally; no other knowledge of his behavior.

Mother's mother.-A wild sort of nature, but not demented. (I0:54, III 6.)

(20) Propositus, $\sigma^{3}$, drinks to excess; is an energetic worker, but is rattledheaded and does not stay long in one position; is sensitive, quick-tempered, and has ugly spells after drinking; wanders from place to place, and is generally known as a "ne'er-do-well." Sibs: I- $\%$, subject to bad "ugly blue spells" at times; otherwise, has a good disposition. $2-0$, in disposition irritable, domineering, of quick temper, and inclined to scold; showed signs of delusions of persecution at about 35; suffered from insomnia and was admitted to State hospital. $3-\sigma^{7}$, intelligent, capable business-man with quiet, kindly manner.

Father.-Unknown.

Mother.- Had bad "ugly blue spells;" for 20 years before her death did not leave the house; had a hypochondriacal tendency. Sibs: $1-q$, inclined to have "ugly blue spells." $2-9$, thought to be mentally and physically normal. $3-0^{7}$, suffers from occasional " blue spells," when he is irritable and unpleasant. $4^{-0}$, had an illegimate child; $5^{-\sigma^{7}}$, subject to depressed periods when he is irritable and unpleasant. $6-\%$, divorced, subject to depressed periods, when she is irritable and unpleasant. $7^{-0}$, always sickly.

Mother's father.-Easy to get on with; after a shock of paralysis became demented; his family "as a race are peculiar and have more or less trouble with their heads."

Mother's mother.-Domineering, irritable, disagreeable; last few years of her life had delusions that men wanted to marry her. Sibs: $1-\sigma^{7}$ died, probably in Louisiana, perhaps in Texas; went South at 20 and owned a cotton farm. 2 to 5 , I brother and 3 sisters unknown. $6-0^{7}$, suicide by cutting throat, owned stage-routes in different parts of the State. $7-q$, irritable, not subject to depression, had delusions that people wanted to get her property; at death "mind all gone." 8-9, a twin of mother's mother, went South to live with her brother (I) after having illegimate child; was domineering, quick-tempered, disagreeable, and tyrannical. $9-\sigma^{7}$, intelligent farmer.

Mother's mother's father.-Little known.

Mother's mother's father's father.-Lived in Connecticut and removed to Vermont. He was sergeant in the Revolution, then a lieutenant, and a captain; was a famous hunter.

Mother's mother's mother.-Nervous, depressed at times, finally demented. (10: $130, \mathrm{X}$ 29.)

(21) Propositus, $\sigma^{7}$, an illegimate son, has no power of concentration. He wanders about a good deal from one place to another. 
F ather-Unknown.

Mother.-Was S.x; used indecent and lewd tall: as a girl: Sib: $q$, died at 14 years. Half-sibs: $1-\sigma^{7}$, of good reputation. $2-\sigma^{7}$, of good reputation. $3^{-}+$, born in Massachusetts; not narried, but liv'ng witl a man in New Hampshire. $4^{- \text {o }}, S x$.

Mother's father.-Ship carpenter; reputation not bad.

Mother's father's father.-Born in New Hampshire and died in Massachusetts: a ship-carpenter.

Mother's father's mother.-Unknown.

Mother's mother.-Never had mental or nervous trouble; is in an almshouse.

Mother's mother's mother.-Little known; she had a sister who had "numb spells."

Mother's mother's mother's father.-Married and removed from Richmond, Virginia, to Massachusetts, died at the age of 45 from an accident at Boston wharf. (I0 : 320 ; VII 8.)

(22) Propositus, $\sigma^{7}$, born 1882 ; has always shown vagrant tendencies; when last heard of was working in a restaurant. Sibs: 1-o, unknown. 2-o, died at 7 years. 3 , died at 3 years. $4^{-\sigma^{7}}$, worked about at odd jobs; seems to show the family traits of dullness and thriftlessness. 5- $\sigma^{7}$, unknown. $6-\sigma^{7}$, works around "more or less" at odd jobs.

Father.-Was steady, but had little skill or anbition; always "jobbed round" for a living.

Mother.-Fairly vigorous, kindly, with very pessimistic ideas of things. Sibs: $1-\sigma^{\top}$, born 1834; sailed away as a young man and was last seen in Providence, Rhode Island; the boat was afterward lost. 2-07, died when 27 at Fortress Monroe during the war. 3-q, stupid, mean, and quarrelsome; had an illegimate cliild after her husband's death; is reticent. $4^{-0}$, married and died a violent death, probably at the hands of her husband. $5^{-}+$, died at 4 years. $6-9$, died at 8 years, brain fever. $7-q$, eloped with a worthless man. S- $\sigma^{7}$, shiftless, ignorant man; a petty thief. $9-\%$, the ablest of the family.

Mother's father.--Little known.

Mother's mother.-Belongs to a family of thieves. (24:36; V S6.)

(23) Propositus, ơ, has an adventurous, roving disposition, thongl he was a good student. Sib: $1-q$, is restless; lıad literary ability but can not do mathematical work.

Father.-Was a Latin and Greek scholar; liked poker. Sibs: 1- $\sigma^{7}$, had nuch mathematical and executive ability.

Father's futher.-A very religious man, interested in foreign 11 issions and reform.

Father's mother.-Musical, literary, and religious.

Mother. - Was subject to nerious headuches. Sibs: 1-or, was restless. $2-\sigma^{7}$, has a roving disposition and lacks concentration.

Wother's father. - A merchant and lawyer; a seliolar; deatli cantised by stoppage of bile-duct at 78 years.

Mother's mother. - Subject to severe sick heuduches; at 7 was totally deafened in riglit ear from searlet fever. (Cos-1.)

(24) Propositus, ơ, born in Massachusetts, 1SS2; quick-tempered and nervous; at i 4 left school, liaving made average progress; was restless; wanted to see the world; traveled from one place 10 another, working at odd jobs whenever he was in need of money; linally went to "l"exas and becance a cowbog:; 
staid a year or so; in 1912 had lumbago; returned home and died. Sibs: $\mathbf{I}-\sigma^{7}$, born $\mathbf{1 8 7 8}$, has led a very irregular life; quick-tempered and impulsive; had very little schooling; was an unustually good musician, and at an early age began to play in orchestra in a cheap theater in W-, Massachusetts; smoked, and at times drank excessively; at i 9 married an actress of 28 years; divorced in a year; since then has wandered about from one place to another, always a little dissatisfied with positions; is at present in California. 2-q, born I 882 , had convulsions when teething; apparently well afterwards, but frail; impulsive and emotional. $3-\sigma^{7}$, born 1885 , had convulsions when teething; quick-tempered and impulsive; married and has a child of 4 years.

Father.-A "normal man."

Mother.-A frail, nervous woman; worries a great deal; hypochondriacal; narrow interests; suspicious of inquiries. Sibs: $\mathrm{I}-9$, born $\mathrm{I} 85 \mathrm{I}$, nervous, hysterical, suspicious, seclusive, worries over trifles; married a "normal man of normal family"; had 2 sons and 2 daughters; both of the latter are "normal"; of the former, the first is nervous, worries easily, and is very sensitive; the second is seclusive, smokes and drinks moderately, a hard worker. 2- $q$, born I 853, a normal woman, a hard worker; of her 3 daughters there is little to note except that one married a Western man and lives in California; of the 4 sons, 3 are living in the same city near their birthplace, and I of frail health, went when young to California, and little of his after-history was learned, except that he married and when 30 years old died of consumption. $3_{-q}^{-q}$, born 1858 , frail, nervous, seclusive, and hypochondriacal; quick-tempered and easily irritated; married a "normal man" and had 2 sons and 2 daughters, none of whom showed marked restlessness. $4-9$, born I 86I, nervous, hysterical, seclusive, worried constantly, had nervous prostration at the menopause (40 years); had no children. $\quad 5^{--\sigma^{7}}$, born 1863 , a bright child, left school to work as a machinist; married at is; of a quick, nervous disposition; he smoked, but no venereal history is known; admitted to State hospital I 906, uneasy, restless, euphoric, paretic; none of his 7 children showed nomadic tendencies. $6-\sigma^{7}$, born I 864 , slow and easygoing; smoked and drank excessively. $7-\sigma^{7}$, born i 866, normal, a day laborer. 8- $\sigma^{7}$, born 1866 , nervous and sensitive, very seclusive, smoked excessively; none of his 4 children ( $\mathrm{I}$ son and 3 daughters) is nomadic. $9-\sigma^{7}$, born I S69, irritable, quarrelsome, violent-tempered; at times has moved about from place to place, never contented to stay long in one place; has not been heard from for the last few years, so his whereabouts are unknown; he married a neurotic woman and has I I children -4 daughters and 7 sons; of the daughters none are nomadic; of the sons the first has epilepsy, is sensitive, seclusive, and now in hospital with typical case of dementia precox; the second is quicktempered, is a clerk; the third started to go to school at 6 years, did not like it, was determined to run away and play with the "toughs" of the village; is now a wood-chopper, smokes excessively, drinks moderately; the fourth is quick-tempered, sensitive; has been committed to a State hospital for suicidal and homicidal tendencies; the fifth was an average scholar, is impulsive, now works in a shoe-store; the youngest two are at school and are sociable.

Mother's father.-Born in Vermont, 1826, and died 1907; he went to Massachusetts in 187 I and was employed as a shoemaker; nothing is known of his early life nor of his fraternity.

Mother's mother.-Nervous, quick-tempered, hysterical; would fly into a rage at the least disturbance; always moving her hands about. (4I : I33; III 71.)

(25) Propositus, $\sigma^{7}$, born I880; of a roving disposition; has worked in many different places; came back to Pennsylvania from Idaho after being 
West 4 years; of an easygoing temperament; handy with tools; aient on hard sprees occasionally; at the age of 32 was found dead. Sibs: $1-\sigma^{7}$, born 1871 ; taught school; went West 10 years ago; farming and lumbering; liad a youthful injury, and thereafter he would occasionally stand motionless, apparently wrapped in deep thought, and his attention could be gained only by calling loudly. 2- $\sigma^{7}$, I $\$ 72$, of average intelligence as a boy; at 25 "had a fever" and was sick for weeks; did not seen to recorer, but became nnclancholy and deranged mentally; had fits of erying and spells of self-accusation; asked lis uncle to burn some hay and put him in the blaze; admitted to the State hospital; his behavior characterized by restlessness, excitement, and a disposition to wander; for 4 months he was noisy, excited, destructive, at times urly and filthy; addieted to masturbation; discharged; married a lazy; unwilling woman, who left him to take care of their little son; now works on his [ather's farm. 3-9, born IS74; taught school; died IS94. 4- ${ }^{7}$, born 1876 ; naturally of a quiet, even disposition, at zo years became hypochondriacal, consumed great quantities of a patent medicine that is thought to have been largely strong whisky, became melancholy, and had fits of crying; [had fits of roing, for] "he went out hunting a good deal;" of ten heard voices up in the woods calling him and he would go up on the hills, sometimes remaining away over night; later became more restless and violent; got up and jumped out of the window; when brought back struggled to get loose; now in State hospital; has mania, fear of drowning and self-destruction. 5-q, born 1878 , lightheaded, silly, and of inferior intelligence; married in IS95; admitted to State hospital I899; removed clothing, tried to run away, and fought all who restrained her; discharged 1900; at times would be unusually restless and sometimes flighty; her husband was unfaithful and she separated from him February I9I I worked for various families, staying with each but a short time; visited her father, September I9II; was nervous, uneasy, restless; admitted to State Hospital November I9I I violent at times; removed clothing; mentally distressed; confused mentally. 6- $\sigma^{7}$, born I 882 and died i 898 of typhoid fever. $7-\sigma^{7}$, born $\mathrm{ISS}_{3}$; irresponsible, simple-minded, unreliable; a glass or two of liquor makes him noisy and hilarious. $S-q$, born $1 S_{4}$; decidedly feeble-minded; does not know right from wrong; has had 4 children illegitimately.

Father.-Born IS4O; a kind-hearted, genial old German farmer; has been well all his life, but can notwork as hard at 72 as he used to; drinks moderately; well thought of by the people in the village. Sibs, father's father and father's mother unknown.

Mother.-Born I $S_{53}$ and died I 885, at State hospital; always showed mental inferiority; neglected home and children; admitted to State hospital I $\$ S_{5}$; acute mania; tears clothing, is sometimes comatose, talks and eats little; she was always domestic. Sibs: $1-\sigma^{7}$, died in infancy. 2- $\sigma^{7}$, born 1855 ; had a hot temper; about 6 weeks before his death (in is 75 ) he had a slight injury; became restless and uneasy at night, $c . g$., went to his brother's in the middle of the night, roused him, and said he wanted to talk to him about business; 2 weeks later had an attack called brain fever; died 3 weeks later. $3^{-q}$, born I 857 ; little schooling; exceedingly hot-tempered; about i 897 became unusually irritable and unstable; went "crazy on religion; went from house to house distributing tracts; developed delusions; hypochondriacal;" had taken about a barrel of "Peruna;" had flight of ideas; admitted to State hospital, suicidal, confused, restless, apprehensive - an involutional melancholia; her only son, born I 893 , is conceited and boastful; left high school at i 5 years; s'ent to Cincinnati shorlly after this, working his way there and back, and has since worked in various places; is an operator with the railroad and wants a posilion as 
brakeman; gets drunk occasionally. 4- $\sigma^{2}$, died in infancy. 5- $\sigma^{7}$, born I $86 \mathbf{I}$, a powerful man weighing about 200 pounds; kind, gentle, and open-hearted; intelligent, sane; is in comfortable circumstances. $6-9$, born 1863 , naturally of a quiet and calm disposition, but subject to nervous and emotional disturbances accompanying the menopause; following influenza became excited, delirious, and was admitted to State hospital, April I910 and again in 1912; emotional, disoriented; has always had painful menstrual periods, frequent and scanty, always followed by a severe headache; for a period of 4 years she had convulsions every few weeks; no children. $7-q$, born i 866 , has a speech defect; gets words in wrong place; leaves out syllables, etc.; is open-minded, childish, emotional; by a consort of inferior mentality she has I son and 2 daughters; the son, born $\mathrm{I} 885$, is of a roving disposition and loose habits; lived with one woman for a while and now lives with another in the metropolis; works in a machine-shop. 8- $\%$, born 1868 , of an unstable nervous constitution, hypochondriacal; has children still young. $9-\sigma^{7}$, died in infancy. Io- o , born I 873 , calm, self-controlled, very religious and supersensitive; married a man who has sprees every month or two; these last for a week and he comes home a "raving maniac"; her eldest son, at $2 \mathrm{I}$, is a brakeman and drinks some because he likes to be "sporty;" the second son, at 20 , is working on his grandfather's farm; likes the taste of liquor, but drinks little, as it makes him sick; the other sons are under 9 years old.

Mother's father.-Born 1831 and died 1907 ; slow and dull; easily influenced; intolerant in religion and very fervid; became childish before he died; did not seem to know what he wanted; would follow one whim one moment and another the next.

Mother's mothcr.-Born 1833 ; an intelligent woman of good business ability and well-educated; nervous, high-strung; became insane in 1858 ("after a sunstroke"); voluble; would call people by Biblical names; bite the bedclothes, and try to tear herself loose; recovered in 6 months and never had a similar attack. $(28: 63$, IV I6.)

(26) Propositus, C. S. R.; is normal, married, and became president of a college in Japan. Sibs: $1-\sigma^{7}$, also married and became an educator in Japan. $2-\%$, married and lives in Pennsylvania. 3- $\sigma^{7}$, lives in Maryland.

Father.-Unknown. Sibs: three $\$$, unknown; father's parents, unknown.

Mother.-Unknown.

Mother's father. - A general in the army. (40:205.)

(27) Propositus, A. M., ơ , born 1899; errand-boy; has a peculiar disposition; runs away; when he comes back promises faithfully to be good; his mother can not control him; he is in an industrial school; was returned for breaking his parole.

Father.-Was in a military band in the Spanish-American war.

Mother.-A skilled needlewoman, separated from her husband.

Mother's father.-A slave; escaped from slavery and ran away to Kansas.

ITother's mother.-Excellent housekeeper and real Southern cook. (Sea-4.)

(28) Propositus, $\sigma^{7}$, born in Illinois, I $8_{5} 8$; is fond of reading and travel; as a boy liked running, wrestling, football; walking and nountain climbing in later years; would study in the very early morning; was prone to dream; abundant hair only slightly gray, though beard is white; appetite under control; irascible; was home missionary; is foreign missionary in China. Sibs: $1-q$, died at $1+$ months. 2-o, born 1862 , teacher in high school; scholarly, witty; strong preferences and dislikes. $3-\%$, born 1864 , teacher of 
drawing and music; social gifts; impulsive and erratic; mainly self-tanght; unreliable in many ways, but brilliant and capable when she tries.

Father.-Market-gardener, student, minister; genial, fond of children, quick-tempered; died of apoplexy.

Father's father.-A stern man; severe in discipline.

Father's mother.-Unknown.

Mother.-Social poise; good memory; sensitive; craved sympathy; inquisitive. Sibs: $\mathrm{I}-\sigma^{7}$, born $\mathrm{I} 829$; fond of horses and known as a horse man. $2-\sigma^{7}$, born I 838 ; very fine singer; remarkable business ability; too fond of women; never drank or smoked. $3-\sigma^{7}$, amiable and popular; got to drinking while in college; enlisted in the army and died of alcoholism while in it. $q^{-q}$, fine executive ability; a leader in church and charitable work. 5- $q$, energetic and capable; social gifts. $6-\%$, rather gay as a girl; married and had a son who was an energetic lawyer; a good speaker, not too scrupulous. By a second husband $6-q$ had another son, a successful business man; has been a sport, but stopped drinking years ago. $7-q$, fond of society; handsome, had issue: (a) $\sigma^{7}$, amiable but alcoholic, died of alcoholisin at 37 years; $(b)$ ㅇ, fine voice, cultivated abroad.

Mother's father.-Farmer, teacher, minister; of good business ability; jovial disposition, sympathetic, easily aroused, inquisitive. Sibs: $1-\sigma^{7}$, pastor of a large church for 30 years; of great influence. $2-q$, unknown; had a son who was a distinguished clergyman, and another pastor of one church for over 20 years.

Mother's mother.-Energetic and efficient; good disciplinarian and of extraordinary beauty. (Cam-1.)

(29) Propositus, $\sigma^{7}$, went to school at 7 years and remained 1 year; he was always a truant and troublesome; at Io years of age he ran arcay to see the couniry; could never keep a position on account of his wandering habits: set fire to a haystack; committed twice for vagrancy, and finally sent to State hospital; he escaped thence 5 or 6 times by picking a lock, and either returned voluntarily or was sent back by the police, having been arrested for intoxication; is now in the State hospital.

Father.-A ne'er-do-well.

Mother.-Became obese and a prostitute of the lowest order, drunken and subject to outbursts of violent temper. Sibs: $1-q$, born $1 S_{+} S$, committed to the State Hospital, 189I, as insane; was at first noisy and violent, soon became quiet, and now dill and listless; is profoundly demented; she married a man who is fat, stupid, and alcoholic; four of the children died in infancy; the fifth was queer and died at 19 years. 2 and 3 , two daughters who died at 21 and 19 years respectively. $4-\sigma^{7}$, born i 855 , has a violent temper, but is not nomadic; one of his 3 sons by a submental wife is in the United States Army, stationed in the Philippines; another is feeble-minded and has two feebleminded children. 5- $0^{7}$, born I 857 ; a very alcoholic piano-tuner; his wife divorced him and he drifted to Connecticut (from Massaclusetts), and into the State hospital for the insane. $6-q$, also became insanc. $7^{-\%}$, an obese woman who has never married.

Mother's father.-Born in Massacluusetts, i $8_{2} 6$, the sixtl child of his parents; a mechanical genius who was a periodic drinker and also a wenderer, who would disappear for months at a time on these trips, cleaning clocks or doing odd jobs and always drinking heavily; after wandering for a time he would return to his home; he disappeared for good 20 years ago. Sibs: $1-q$, born in Massachusetts, is I5 $_{5}$, a peculiar woman, who went insane at the birth of each of lier children, was committed to the State hospital in is +4 . had been suicidal; by 
her ineffective husband she had 5 children: (a) $q$, born I 848 ; nervous and somewhat secretive; by her farmer-husband she had a daughter (who is married and has a bright young son) and two sons, the elder of whom is very alcoholic and is an oculist in Los Angeles, California, while the younger is in a factory near home; $(b)$ 우, born 1840 , who became very obese; she married and had 12 children and a number of grandchildren, none of them nomadic; (c) 9 , born I $84 \mathrm{I}$; her marriage was a forced one; she grew very peculiar, but was never committed; she had 2 children by an alcoholic husband; the only one who survives has delusions; $(d) \sigma^{7}$, born $18_{43}$, is a shoemaker in Ohio, drank heavily, and had 6 children, none nomadic; (e) + , born i 846 , has prolonged depressed spells and has suffered an apoplectic shock. 2-0, born is 8 , was alcoholic; his children are little known. 3- 5 , born 1818 , died in 1839 from injuries received while clearing land. $4^{-}+$, born 1820 , died of tuberculosis in 1865 ; her only son was a druggist who died of tuberculosis at the age of 27 years. $5-\sigma^{7}$, born I 823 ; drank heavily; grew obese; was killed in the Civil War; by his wife, from Maine, he had 4 children: (a) $0^{7}$, born 1848 and died of tuberculosis 1867 ; was a shoemaker; $(b) \sigma^{7}$, born 1850 ; placed by his stepmother in the almshouse, he ran away; caught and bound out to a private family he ran away again; he has a great deal of mechanical ability, but he never sticks to anything; he wanders a great deal, doing odd jobs for several months at a time, but seldom remaining long in one place; he is a shoemaker, also a machinist, by trade; he has invented machinery used in the manufacture of shoes, also a "wheel crimper" for the edges of pies; by his cousin R- he had one child, a son, who is capable of good work, but who drinks very heavily and is at present in Canada. $5-\sigma^{7}$, by a second wife had 3 sons: $(a) \sigma^{7}$, born I 859; was a fine scholar; ran away from home and lived for some years with a hermit, occasionally peddling notions to get a few cents; he was never content to remain in one place, however, often taking trips to the surrounding towns, and finally ran away about 20 years ago and has since never been heard from; (b) $\sigma^{7}$, born $186 \mathrm{I}$; is said to be very peculiar and "too stingy to drink"; (c) died in infancy. 6- $6-\sigma^{7}$, born 1828 , was addicted to the use of alcohol; went to the Civil WVar, returned home, married, settled down, and has a son who is a weaver in a mill near by. $7-q$, born I 830 , died 1880 of tuberculosis, married a machinist and has a surviving daughter who is not nomadic and has a son who works near by. By a second husband, $7-9$, had 3 children who survived infancy: one son who is a shoemaker, one who is a motorman, and a daughter who has married and settled down near by. $8-\sigma^{7}$, born i 833 , was a shoemaker; went to the Civil War; received a pension and had poor health during latter part of his life; he had 9 children, none of whom were nomadic. $9-q$, while a child, was burned to death in a bush-fire. Io- $q$, born 1836 ; after the death of her husband fell into sexual irregularities; by her husband, who was a machinist, she had one son who grew up with little maternal care, ran away to sea and was not heard from for 9 years; was a British soldier for 5 years, and at last accounts was said to be keeping a light-house on the coast of Florida.

Mother's father's father.-Born in England, I773; was a soldier in the WVar of 1812 on the British side; he had been a soldier in the British army for some years, and his descendants say that he had been all over the world; whether his early life was responsible for the roving disposition which manifested itself later or whether he was naturally restless is unknown; his children were all born in different towns, which shows that his roving disposition lasted him throughout life; he was a shoemaker and a machinist and died in 1837 of tuberculosis.

Mother's father's mother.-Became very obese; weight over 300 pounds.

Mother's mother.-A bright, witty woman who had been a school-teacher; too fond of reading to make a good housekeeper. Sibs: $1-\sigma^{7}$ was a soldier in 
the Civil War and was killed in 1863; had 3 sons, 2 of whom worked on the railroad and I was an inspector for a loconnotive works in Philadelpliia. 2-0?, a foreman in steel works; he had 8 children, none nomadic. (38:33.)

(30) Propositus, $\sigma^{7}$, when a boy of 16 was kicked in the head by a colt and shortly afterward had epileptic seizures, which have continued throughout his life; when last seen he was "leading a hobo existence." Silss: $1-\sigma^{7}$, died in childhood from an accident. $2-\%$, died in infancy. $3-\sigma^{7}$, is now a ratleer garrulous old man; has becn quite successful in his business ventures; was a carpenter, then took up structural engineering in Mexico; servert as captain in Union army; for many years employed in Post Office Department at II asliington; he married, but notling is known concerning his consort; they had: (a) $\sigma^{7}$, at present farming in Wisconsin; is rather unstable and apl to change occupations frequently; $(b)$ o , married and lives in Seattle, Washington; (c) $\$$, little known; (d) $\sigma^{7}$, said to have had good liabits. 4-0 , died somewhere out West. 5- , married a ne'er-do-well, from whom she was divorced.

Father.-No data.

Mother.-Always a healthy woman. Sibs: I- + , never married. 2- , lived to be very old. $3-\sigma^{7}$, died at 19 in Michigan; $4-\sigma^{7}$, peculiar, committed suicide. $5-\sigma^{7}$, died at 2 years. $6-\sigma^{7}$, died of tuberculosis at $40.7-\sigma^{7}$, died young of tuberculosis. 8- $\sigma^{7}$, clied at 19 of tuberculosis. 9- $0^{7}$, when 15 ran away from home after a severe flogging; became very alcololic and was demented before death; he had a son who remained 37 years in one position.

Mother's father. - A man of violent temper; at times would disappear from his home and remain away for several days or weeks and his family never learned where he spent his time.

Mother's mother.-I,ittle known. (13:64, III II.)

(31) Propositus, $\sigma^{7}$, developed vicious traits; ran away at the age of $I f$, and has not been heard from since. Sibs: $1-\sigma^{7}$, unable to learn at school; lazy, licentious, and alcoholic. $2-q$, burned to death in a brush-fire.

Father.-A lazy, alcoholic negro.

Father's father and mother.-Unknown.

Mother.-Fairly quick in movements, but indolent and unambitious; can not tell her own age, and is completely illiterate-an imbecile. Sibs: $1-0^{7}$, lazy, licentions, vicious, alcoholic; he served a term in State prison for arson and a term for threatening to kill.

Mother's father.-A lazy, licentions man, who some time after his marriage disappeared for good.

Mother's mother. - A harlot with a wandering impulse that led her to tramp the roads. (E. R. O. Mem. No. 2, p. 18; VI 98b.)

(32) Propositus, born I 854 in New Jersey; he is an alcololic wanderer: wanders all over the $W^{\prime} e s l$; never succeeded at anything. Sibs: 1-q. normal mentally; lias one son who is a traveling salesman; the second is at the state university. 2-q, normal mentally; married a man of insane stock: lias one daughter who is melancholic. $3-q$, died young. $4^{-q}$, has heart trouble; has 7 cliildren: (a) of, lizes oul II est, married and separalcd: (b) o7. uninarried, normal; $(c) \sigma^{7}$, on staff of aviation magazine; $(d)$ q , musical; $(c) q$, stenographer. $5-\sigma^{7}$, died at 17 years of appendicitis. $6-\sigma^{7}$, superintendent, electric light company. $7-\sigma^{7}$, in mining business, Colorado.

Father.-A farmer of New Jersey.

Mother.-Normal mentally. Silos: $1-\sigma^{7}$, died of paralysis; $2-q$, died in infancy. $3-0^{7}$, storekeeper; $4-\sigma^{7}$, normal 11rentally; $5-9$, very bright, memory good. $6-9$, normal. $7-\sigma^{7}$, when old iedulered about one ciening and 
was found dead on the river-bank in the morning; had been depressed for some time. $8-0^{7}$, storekeeper, normal. $9^{-\%}$, never bright; queer, impulsive; a drug fiend.

Mother's father. - A tailor by trade; said to be normal mentally; had a sib who was called insane. (14:3849, III 34.)

(33) The principal fraternity consists of 2 boys; the elder ( 15 ) is welldeveloped; he joined the navy last Spring, lying about his age; the younger ( 13 ) also well-developed; has been restless since his birth; has frequently run away, is a truant from school, and was finally expelled for "bumming;" he selects bad companions and he lies so as to be quite undependable.

Father.-Had low instincts; gambled, was dishonest, drank, staid away much from home, and acquired venereal disease after the birth of his younger son; the father's father was good but peculiar; had a great gift for mathematics, but could not read nor write; was eccentric and very religious; the father's mother was fast and left her husband to go with another man.

Mother.-An intelligent, strong, fine woman, who, since her divorce, keeps a rooming-house; one of her brothers is in the automobile business, the other is a lieutenant in the Philippines; one sister was unruly for a time, but made good.

Mother's father.-We have only the record "good man, dead," and know nothing about the mother's mother's characteristics. (3:152.)

(34) Propositus, born I878; of roving disposition; now in the navy; unmarried. Sibs: $1-0^{7}$, born 1884 , died in Philippine war. 2-o, unknown.

Father.-."An oddity."

Mother.-Born I852; very bright; has a pleasing personality and a keen sense of humor. Sibs: $10^{7}$, born 1836 ; strong, healthy, energetic, conceited, arbitrary, separated from wife. . 2-0 $0^{7}$, born 1838 ; a hand-carver. $3-9$, born I 840 , was like her father's people. $4^{-}+$, born I 842 , unknown. $5^{-}+$, had puerperal mania after birth of sixth child. $6-q$, well and strong. $7-q$, a teacher, pleasing personality. S-o, unknown. 9-o, unknown.

Mother's father.-Was a dyspeptic and nervous; he became restless and unsettled, went from one child to another, and a few days before his death (of heart failure) he insisted on taking the journey from Pittsburgh to Doe Run, Chester County (about 275 miles). Sibs: I- 9 , unknown. 2-\%, had good health. 3-o, unknown. $4^{-\%}$, clear-minded. 5- $\sigma^{7}$, a man of prominence and wealth, not nomadic. $6-\sigma^{7}$, a blacksmith of fine character. $7-\sigma^{7}$, honorable and straightforward; lost his mind at the last. 8-o, nervous, whimsical, complaining. $9-\sigma^{7}$, respected Quaker physician; lost his memory toward the last. Io- $\sigma^{7}$, an opium-fiend, indolent, egotistical; memory failing.

Mother's father's father.-Born 1784 , was a heavy drinker on sprees; went around the country among the distilleries. ( $7: 283$, IV 6r.)

(35) Propositus, $\sigma^{7}$, was wild, wandering; brilliant but unbalanced; died insane in San Francisco. Sibs: $1-q$, a philanthropic woman; calm, brilliant; had imaginary ailments and nervous prostration; went insane; died of a clot on the brain.

Father.-Of a brilliant family with some insanity.

Mother.-Little known. Sibs: $1-\sigma^{7}$, bright, lived in China for years; a drinker. $2-\%$, mentally well. $3-\sigma^{7}$, editor in San Francisco. Others, little known.

Mother's father.-Died of paralysis; nothing known of his traits.

Mother's mother.-Unknown. (7:332, V iq.) 
(36) Propositus, $0^{7}$, could recite stories at 22 inonths; $110 w$, at to years of age, is in school, where he is inattentive, thongh scldom absent; he likes adventure, and goes away, without permission, with bad associates; lies sometimes, but will tell the truth if pressed to the point of punishment. Sibs: $1-\sigma^{7}, 19$ years, had a good mind and is studious. 2, died in infancy; $3-\sigma^{7}$, 15 years, is "bright and good."

Father.-A successful lawyer of strong character; no evidence of nomadism in his ancestry.

Mother.-A very intelligent woman of firm cliaracter. Sibs: $1-\sigma^{7}$, lefl home at I4 to seek life of adventure; reads much in books of travels; married unhappily, but has settled down. 2-o, married unhappily; is in business for herself.

Mother's father.-A good man, but very nervous; had no patience; was severe with his boy.

Mother's mother.-Comes from a staid Boston family of 14 children, all of whom turned out well; one of her brothers, a lawyer, who married beneath him, had a son who is a rover; has been in the navy and his present whereabouts are unknown.

Mother's mother's father. - Was a captain in the Black Hawk War; he went to Illinois in 1826 ; he was erratic, very fond of Indian out-door life, and always used an Indian blanket; at over 70 he swam the Mississippi; he traced his ancestry back to Pocaliontas. $\left(3: 95, \mathrm{IV}_{4}\right.$.)

(37) Propositus, ơ , born in New York, 1896 ; had convulsions at 2 years; was stubborn and unruly and would throw things at an offender. He had a tendency to wunder; he would leave home for days at a time and wander about the city, often bringing home a collection of things that, he said, people had given him, but his mother evidently suspected him of stealing. On his last absence from home he wandered about his native eity, hiding as much as possible and returning home at night to sleep in the coal-bin. Now in a State institution for defectives. Sibs: $1-\sigma^{7}$, born 1893 , a drummer in the theater; exceptionally bright and very musical; has a tubercular spinal trouble. $2-\%$, died at 2 years. $3-\sigma^{7}$, born 1898 , a junior at the academy; very talented along musical lines and plays cornet; is a well-known and popular actor. $4^{-7}$, born 1900, backward in school; dislikes study; fond of baseball and moving pictures. 5-9, born 1902; has remarkable histrionic ability and plays the violin well with little training.

Father.-Born 1867; died 1902, from an electrical accident; had a good mentality and was well thought of; liad 4 sisters, all normal, and 2 brothers, of whom one is normal and the other died at 28 years of spinal trouble; 2 other brothers died early.

Father's falher and his sibs: Normal, except one brother, who was not very bright.

Father's molher.-Fiormerly a bright woman, now suffering from loss of memory.

Mother.-Intelligent, talented, and of good character, lias kept the fanily together by giving music-lessons. Sibs: $1-q$, died at 2 years of spinal meningitis. $2-0^{7}$, died at 12 years of spinal trouble. $3-\varphi^{\circ}$, not cleseribed. $4^{-}$ㅇ , mentally normal. $5-\sigma^{7}$, bright; died at 45 of heart disease. $6-\%$, an attractive woman, living in her native town.

Mother's father.-Came to America from Ireland; died of a goitre (?). Sibs: $1-9$, remained in Ireland; of the renaining three sisters and two brothers there is little knowledge.

Mother's mother.-A bright woman; came to America from Ireland at the age of 7 years. Sibs: $1-q$, respectable and intelligent. $2-\sigma^{7}$, never con- 
sidered "right" mentally; undoubtedly feeble-minded; the patient's actions are said by his mother to resemble those of his great uncle; he was kept at home, but was never dependable and would go off on a tramp at any time; was never responsible and always had to have some one looking out for him. $3^{-0}$, normal. $4^{-9}$, bright. $5^{-0}$, normal. $6-9$, bright. $7^{-9}$, died at is years "of a fever." $(54: 23, \mathrm{~V} 5$.

(38) Propositus, $0^{7}$, born 1841 , has always been a wanderer; he is lazy, has frequent crazy spells, swearing and driving family out of house; has been a drinking man. Sibs: $1-9$, unknown; $2-\%$, died young. 3-o, unknown. $4-0^{7}$, unknown.

Father.-Unknown.

Mother.-Unknown. Sibs: $1-\sigma^{7}$, died of old age. $2-\sigma^{7}$, drives a stage. 3-o, unknown. $4-0^{7}$, drinks.

Mother's parents.--Unknown. (36:24I, III 16.)

(39) Propositus, $0^{7}$, died in Georgia; he was of a restless, roving disposition; never married. Sibs: $1-9$, very intelligent; she had: $(a) 0^{7}$, who was insane, mind now clear, expression dazed; $(b) o^{7}$, died at 67 years; $(c) o^{7}$, died of apoplexy; also 3 other girls and $\mathrm{I}$ boy unknown. $2-0^{7}$, very nervous, became insane. $3-0^{7}$, farmer. $4-0^{7}$, farmer, good-natured. 5 to 7 , unknown.

Father.-Was a farmer and a constable.

Mother.-Died in childbirth at 40 years.

Mother's father.-Came from Germany and is said to have been queer. (39: 473 , III I 5 .)

(40) In the principal fraternity $I-\sigma^{7}$ is a wanderer whose whereabouts are unknown; $2-\sigma^{7}$ goes off on sprees; $3-\sigma^{7}$ has run away; $4-\sigma^{7}$ was killed in a drunken brawl; $5-\sigma^{7}$ has gone away; 6 , probably died in infancy; $7-\sigma^{7}$ was constantly playing truant at school.

Father.-A notorious character; came of a long line of liars, thieves, paupers, and criminals.

Mother.-Is a member of a family which has had paupers for nearly $15^{\circ}$ years. She was very attractive and interesting as a girl, but has been lax in her morals. Sibs: I- 9 was quite lacking in the moral sense; her husband, who vied with her in immorality, at one time deserted her and drifted about from place, earning just enough to keep him alive; they have a daughter who was constantly running the streets and parks, ran away from the State home and was found in the metropolis; later she planned a runaway unsuccessfully. $2-O$ has a home that is a dive for the drunken and unchaste; by a drunkard and thief she had a daughter who at 14 is constantly running the streets. $3^{-9}$, an immoral girl of low mentality. $4-\sigma^{x}$, a thief and $S x \cdot 5^{-7}$, considered the worst of the family, was killed while drunk. $6-\sigma^{7}$, a thief, alcoholic, a fighter. $7-0^{7}$, a thief, grossly immoral. $8-0^{7}$, an immoral, thieving pauper. $9-0^{7}$, not as evil as his sibs.

Mother's father. - A man of very bad repute; a drunkard and thief and grossly sexulal; had capacity for but distaste of work.

Mother's father's sister's son.-Was a fair reputation, but has been known to steal hens; married a shiftless woman of undesirable reputation; they

a son who wanders about from place to place; the mother's father's brother's son, an industrious man, married a woman of good reputation; he has a wandering disposition and has had good situations but never keeps them long.

Mother's father's father's sister. - Was a fortune-teller who wandered away. (9:507.) 
(41) Propositus, $\sigma^{7}$, is of a roving disposition, never liking to stay long in one place; is quick-tempered. Sibs: $1-\sigma^{7}$, silent man, yet goes to cluturch and enters into any social life that is going on. 2- $\sigma^{7}$, very quick-tempered, but intelligent. 3- $\sigma^{7}$, no mental trouble. $4-q$, jovial, but has had attacks of mental trouble from time she was 16 , and the onset of these thouglit to liave been coincident with onset of menstruation; admitted to hospital as manicdepressive, is now fecble-minded. $5^{-} q$, has a quick, ugly disposition and fies in to a temper, subject to periods of mental trouble. 6- + , slow, even-tempered, unimaginative. $7-q$, of quiet, sociable disposition, though she does show temper at tines. $8-q$, lacking in intelligence. $9^{-q}+$, most intelligent and capable of her fraternity. $10-\%$, at 22 becane depressed, has regular periodical atlacks, displays sudden outbursts of temper. 'The eldest in this fraternity died in infancy.

Father.-Firm and determined; very obstinate; most of his sibs moved West years ago.

Father's father.-Born in New York, probably a pharmacist, died in Pennsylvania.

Father's mother.- Soon after the death of her husband she went to Wisconsin, taking most of her children with her.

Mother.-A very quick-tempered woman; died from stroke of paralysis. Sibs: $1-\sigma^{7}$, a quick-tempered farmer who died of an apoplectic stroke; his son married a sharp, decided, strong-minded woman and had several sons, one of whom has a roving disposition. 2- $\sigma^{7}$, a "shouting Methodist." $3^{-q}$,

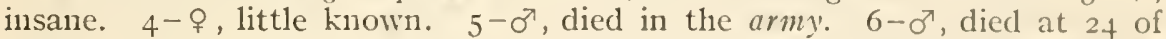
typhoid fever. 7 -o, no mental trouble. $S-q$, slow, practical, matter-offact.

Mother's father.-Quick-tempered; a very hard drinker.

"Mother's mother.-Strong-minded;" died in stroke of paralysis. (28:291. III-I9.)

(42) Propositus, II 20, $0^{7}$, born ${ }^{8} 8_{4}$, was a very peculiar man; he aundered about from place to place, never visiting his married children; his sister is extremely voluble; she shows that wanderlust that her brother had, to get from one place to another, and some of her 6 sons show it; they no more than get a house built to order in one place than they sell out and go to another to do the same thing over again; II 20 married a woman who belongs to a nervous fraternity, but is the least affected; she had the migraine that the others had, only to a less degree; there were $f$ children. 'The only son of II 20 was a blacksmith who abandoned that occupation on account of lis healel, he went to Europe for a while for his health; is now a janitor and has not missed a half dozen day's' work in 5 years; he is very nervous; his only child died in infancy. A daughter of II $20, \mathrm{E}-$ - born is 66 , is a dressmaker and single; had crying spells during involution, but is all right now, since a trip for I I weeks that she made to Oregon with her aunt. A sister, III 43 , is of a calm type, formerly subject to headaches; she married a drinking man and has had 8 children; of these one died in infancy and two others under 12 ; there remain 3 boys and 2 girls; the oldest boy, born 1 S92, left the eiglith grade in school when he was 16 and is working in a factory; the second, born isy6, left school in the seventh grade and runs an automatic engine in a box factory; the third, born 1897 , left school at $5_{5}$ and is learning printing; one of the two girls at 19 has St. Vitus dance; the other is working in a factory in an neigleboring town. There is no evidence in the record of nomadism in any of these children (although expectation is that one or two of the boys would show their mother's father's restlessness). Finally, III 45, the youngest danghter, lias 
migraine and nervous trouble, winks constantly, and has attacks of melancholy; she has only 2 young daughters. (22:242, II 20 .)

(43) Propositus, a 7 -year-old boy, goes off by himself and not with other boys; at 6 years he was in the second school year; plays truant; works well except during his queer spells; writes 6 to 8 letters a day to his mother; is intelligent and able; he "knows what is going on at a distance" and anticipates questions; is obstinate and self-willed; runs away and says he does not know why he does so; when spells of going off come on him his whole expression changes; his face seems to bloat, lips get thick, eyes bloodshot, and, if angry, he growls; he is usually fond of neat, clean clothes, but when the spells come on the worse he looks the better he seems to feel; his mother has accused him of taking things. Sibs: $1-\sigma^{7}$, died at 9 months of pneumonia. $2-\%$, a bright girl, probably about 5 years old.

Father.-Born in Sweden, a Methodist minister; is very selfish, has an ungovernable temper, and has abused his son frightfully after he had run away; he goes to brothels and lives at a hotel because, he says, his wife "gets on his nerves." Sibs: Five survived infancy; of these 4 are not described; one is "very erratic."

Father's father.-A soldier, very erratic and superstitious; used to walk in a graveyard at Christmas time and perform incantations.

Father's mother.-Unusually strong and intelligent for her type.

Molher.-32 years old; as a child anemic, neurotic; 5 years ago had an attack of nervous prostration; before birth of her last child she had mental derangements with blank periods; she wandered in the park, thinly clad, for 7 hours; she has definite spells when she does not know her husband, and after such spells she does not remember what occurred in them. Sibs: i to 3, 우의, not described. $4^{-}+$, has a peculiar love for animals and keeps a small menagerie of monkeys, etc. $5-\sigma^{7}$, normal. $6-\sigma^{7}$, exceedingly erratic; not vicious, but has occasional peculiar lapses when he will jaunt off; once, after he was a married man with a family, a train came by where he was resting, he suddenly jumped on the train and was away for a month. $7-\sigma^{7}$, exceedingly erratic; always a wanderer and, as a lad, served time in a penitentiary; despite active attempts to locate him he can not now be found.

Mother's father.-Deserted his family about the time the "Mother" was born and nothing is now known about him. The family was broken up and the different members taken in charge by different friends. This father was erratic, but probably not a drunkard.

Mother's mother.-Unknown. (3:100.)

(44) Principal fraternity: I $-\sigma^{7}$, a farmer who died an old bachelor. $2-\sigma^{7}$, a traveling salesman, unmarried. $3 \rightarrow 0^{7}$, lives in Chicago, is a photographer. $4^{-\sigma^{7}}$, a farmer, unmarried. $5^{-\sigma^{7}}$, a traveling man in the West. (The field worker remarks that all but one of these brothers followed a business which had traveling in it.)

Father.-Married and moved out West. They traveled all through the West like gypsies, in a camping-wagon. They never had a home and the father never would settle down and work any length of time. He enjoyed absolute laziness, sitting all day and smoking his pipe. Sibs: $1-\sigma^{7}$, unknown; he had 5 children: $(a) \sigma^{7}$, a harness-maker; (b) $\sigma^{7}$, an old bachelor and a drunkard; (c) $\sigma^{7}$, very alcoholic, separated from liis wife; they had 3 sons, none of whom married; the first is an actor traveling with a theatrical company, the second is a ne'er-do-well, the third smokes, drinks, and is worthless; $(d)$ o , unknown; (e) + , undescribed; one of her daughters has nervous headaches. 2-0 
normally nervous, irritable, stuttering, and peculiar; originally a tailor, he took to house removing; was a steady worker; at times showed a manic tendency; was for a time fond of horses, but dropped this interest; having quarreled with a neighbor, he built a high fence against this neiglibor's lot; married a highly neurotic, unrefined woman, who deteriorated mentally, and they had one daugliter (who was a self-willed child, committed to a State hospital on account of dementia precox), and another daughter who is irritable, unsocial, and stutters; also 2 sons, of whom one has defective speech and the other died at 4 years. $3-\sigma^{7}$, a farmer, not nomadic. $4-\sigma^{7}$, became depressed. $5-\sigma^{7}$, little known. $6-\sigma^{7}$, kind and lovable, died at 20 years. $7-\sigma^{7}$, died unmarried. $8-\sigma^{7}$, was unsocial and disliked.

Father's father.-Always restless, trying new schemes; started up silkworm industry only to let it fail when he lost interest.

liather's mother.-Normal.

Mother.-Traveled with her husband like gypsies.

Mother's father and mother.-Unknown. (21 :29.)

(45) Propositus, $q$, is a wanderer and has been traveling abroad for a number of years; she comes back to this country, but after being here a while bccomes restless and has to move on. Sibs: I, died in infancy. 2-or, born in Pliladelphia, lieutenant of revenue-cutter in California, married and divorced twice. 3- $0^{7}$, died in infancy. $4^{-9}$, married her music-teacher and lived in Unitcd States and abroad. 5- $0^{\pi}$, at 16 ran away from home (father had threatened to whip him if he attacked his sister), and nothing was heard of him for several months; placed in State hospital, he eloped 7 times; has been in the army 3 times and in the navy (surreptitiously); while out of hospital he keeps a job but a month or two and then wanders off to another place; is restless, will not stick to anything; went to western Canada to begin life anew, but came back in 2 months.

Father.-Formerly was an army officer; now retired; formerly took some trips abroad; largely "to gratify his wife." Sibs: $1-\sigma$, died in infancy.

Father's father.-An eminent New York surgeon and physician.

Father's mother.-A patient woman.

Mother.-Always wunted to be on the go and went away to visit, leaving her babies with the father and a nurse-girl; becante insane. Sibs: $1-\sigma^{7}$, very nervous. $2-\sigma^{7}$, mildly insane. $3-\sigma^{7}$, always caused his family much trouble and expense by his wandering over the country. $4^{- \text {o }}$, frenzied, suicidal, cpipcltic. $5-\sigma^{7}$, normal.

Mother's father. - Left England ut 12 y'cars of age, wenl to Spain. Africa. South America, and Australia; landed at l'cei Jork ubout 1840 with $\$ S 00$ savings; went near South Bend and started a fontudry; 10 years later sold out and went to Cleveland.

Mother's mother. - I woman of excellent connections. (25: IOS, III 7.)

(46) E's father and mother a'ander about the country, the mother with a peddler's basket and the father with an numbrella-1naker's ontlit. I: has violent outbursts of temper. At Christian Home she ran wa'ty and when placed by them in private families she ran aiv' $y$. Sometimes she would only run a short distance, be satisfied, and return. When locked in her room she would climb out of her windoi', run a short distance and come back. She is the only child of her parents. (34: 100.)

(47) Propositus: "At times she has an irresistible inclinution to run aw'uy." She has 110 full sibs. 
Father.-Is content to commit himself as a vagrant and remain in the local jail during the winter, but as soon as spring comes he must be on the open road. He has held positions in quarries and mills, but not for long, always setting off again as a "socker" or umbrella mender; can make $\$ 4$ to $\$ 6$ a day, but it is all dissipated in drink; every spring he and his wife declare that this time things are to be different; they will take care of their money, and in the fall get a room somewhere; but every fall they turn up at the local jail.

Father's father.-Unknown.

Father's mother.-Unknown.

Mother.-Immoral as a girl; since she married patient's father she has been traveling around the country with him, carrying a huge peddler's pack on her hip; she gets drunk a great deal; every fall she gets herself committed to the local jail as a vagrant and spends the winter there. Sibs: I- $q$, born 1863 ; a prostitute, has been in jail several times; answers advertisements by Western men seeking wives and asks for money to go out, then keeps the money and doesn't go. $2-q$, was married and divorced, was a prostitute. $3-i$, conduct unknown. $4^{-0}$, went insane.

Mother's father.-Behavior unknown.

Mother's mother.-Died of a stroke; had four brothers, of whom 2 drank themselves to death. (39: 100.)

(48) Propositus, ㅇ , married first a tramp and ran away and tramped with him. She is probably nomadic. Later she married a feeble-minded man who is not a tramp and by him had two children.

Children.- $1-0^{7}$, born 1876 ; is married, but did not support his wife, and finally ran away; has no home; tramps and won't work if he can help it; drinks. $2-q$, born 1875 , is feeble-minded, vicious, and ugly; has a violent temper, but is not nomadic, so far as the evidence goes. (32:163.)

(49) Propositus was a shoemaker and of a roving disposition; traveled back and forth between New England and Mexico, where he was interested in some mines. He had a brother who died suddenly, apparently in a convulsion, was temperate and had a peculiar twitching of one eye and has a child with the same. A sister died of tuberculosis at 25 years; 5 other sibs died at 14 or younger ( 3 in infancy).

Father.-Was a shoemaker and a seaman, according to the season of the year.

Mother.-Died of tuberculosis in childbirth. Sibs: $1-\sigma^{7}$, a shoemaker, extremely epileptic; lie developed many mannerisms, such as wearing his bandana handkerchief protruding from his pocket; grew very eccentric and died demented. $2-q$, an industrious, energetic young woman of very excellent character; was much in demand as a seamstress; grew demented at 73 years, at times violent. $3^{-\%}$, had always bad nervous headaches. $4^{-\%}$, has long suffered from recurrent melancholia with suicidal tendencies; once wandered in a half-dazed condition for a half mile from the hospital; on one occasion when her infant was only a few weeks old she walked with it in her arms, in the spring of the year, a distance of 7 to 8 miles, when the roads were deep with mud; her cousin saw her coming down the street toward the cousin's home, a shawl over her head, her dress wet, muddy, and frayed, and with the look of a tramp about her; when questioned she could give no reason for her conduct, so the matter was not discussed by the family; has two sons who seem steady and loving. 5- $\sigma^{7}$, little known. 6- 9 , tubercular; died of pneumonia.

Mother's father. - Was a skipper of a fishing-vessel; he was a quick-tempered, capable, energetic man. Sibs: $1-\sigma^{7}$ was a cooper and a "Millerite" who believed that the world was soon to end. 2-ol, nothing known about his 
behavior, 3- $\sigma^{7}$, a cordwainer and cooper. + $\sigma^{7}$, as a young man "went cook" to sea and saved $\$ 3,700$, which he put in the bank; he was very close, conceited, egotistical, garrulous, stubborn, and not alcoholic. 5- 5 , a short man, served in the Civil War, was a sea-captain at one time and when an old man was "ship-keeper" for ships in port. 6-o", a sea-going man who died unnarried at 25, went to the "Banks," and went on trips to study navigation. $7-\sigma^{7}, a$ shoemaker; went to the Civil War "under age," took a lively and valiant part in the battles on the sea waged by the Monitor; after the war, had melancholic attacks; he was not alcoholic, but quick-tempered and dicel demented. 8-q was very exacting and "finicky".

Mother's father's father.-A cooper.

Mother's father's mother.-Died of tuberculosis.

Mother's mother.-Always notably a great worrier, particularly over her numerous sea-going relatives, for fear that someone would be lost at sea. Sibs: $1-\%$, died of cancer. 2- $0^{7}$, a seamun. 3-q, died at 5 years. $4^{-q}$, upright, exceedingly stern woman; became a man-hater; died demented, stubborn, childish. 5- $\sigma^{7}$, a shoemaker, rough in manner, lives with his sister (4); has never married. 6 , died at 2 years.

Mother's mother's father.-Drowned out of a dory. (12:21, V 73.)

(50) The principal fraternity of 5 comprises + men, of whom one now "wanders about," childless; another "has shown a "agrant tondency, little feeling of responsibility and large imagination all his life;" a third was epileplic in his youth; and a fourth is an honest, sober, but ineffective man. 'Thus two are nomadic and two are not. Of the sister we only know that she is "fairly educated and highly respected in her community and church."

Father.-Ilandering, alcoholic, thrown into convulsions by whisky; of a strain showing much vagrancy, alcoholism, epilepsy, and imbecility.

Mother.-A feeble-minded but moral woman of defective German stock.

Mother's father.-D. H. (E. R. O. 24:299). He was without sense of number and proportion, and although he went to school for several years was never able to learn anything. He was too feeble-minded to plan his work carefully or successfully and too careless and slack to do well what was planned for hinl. The land which he did not sell fell into disuse, and his neighbors, ont of pity, nsed to have him do simple tasks for thenl, but he conld not be relied upon to use even the hoe properly.

Mother's mother. - Was very wild and dissolute as a girl; the common property of the dissolute young men of the neighborhood. She has preserved her reputation for licentiousness througliout lier married life. Her house is never clean nor the food well-cooked; everything goes without plan or purpose, while the mother races the countryside 5 days out of every week, retting entertainment for herself and her children from anyone whom she can impose upon. Of the forbears of this woman we are told only $(24: 300)$ "her immediate family were of fairly good repute, thrifty, poor, liardworking, but belonging to a strain showing lack of sex-control. (24:30S.)

(51) Propositus, o7, was a high-spirited man who was fond of the ute'nturous life of the sailor and was lost at sea when but 20 . Sibs: $1-q$, was a schonl teacher before marriage. $2-q$, died in infancy. $3-\sigma^{7}$, is a marine cngineer, lias mechanical ability, is fond of trued. $+-\sigma^{7}$, is a clergyman and teacher; he is fond of natural history, fishing, and of chess; he is a great aidker, is fond of nature study, and is very "set" in opinion. 5- $\sigma^{\text {" }}$, is an imarnative, brilliant, affectionate, and religions man.

Father.- Has had severul places of residence, was a splendid business man, and had excellent judgment. Sib : $1-q$, a very jolly, lumorous woman. 
Father's father.-Was a sea-captain sailing to the West Indies.

Father's mother.-No especial data.

Mother.-Was a skilled needlewoman, fond of flowers, music, and children; was religious; she was bedridden for 3 years.

Mother's father: Was a pioneer; he served in the War of $I \delta 12$; he a'as fond of fishing, was musical, and a successful inventor.

Mother's mother.-Died of consumption at 22; was fond of music, painting, and fine needle-work; was religious. (Bat-2.)

(52) Propositus, $\sigma^{7}$, died at 2 I years, of an abscess on the brain. He was a restless, wandering lad and man. Sibs: $\mathrm{I}-\%$, is very nervous; rapid and nervous in speech; stammers noticeably when excited; is liable to nervous abstraction. 2-q, had nervous prostration; nervous exhaustion. $3^{-\%}$, died at 25 years of bone tuberculosis (?). $4-\sigma^{7}$, died at I 7 years of diphtheria. $5-9$, married and gone to Mexico, not heard from in a long time. 6-, , unknown.

Father.-A shoemaker in winter and mackerel fisherman in summer; he also owned a farm of 18 acres that he cared for; never voted, as he mistrusted the government.

Father's father and mother.-Unknown.

Mother.-Had manic depressive insanity in both elated and depressed forms; had delusions of persecution. Sibs: I- + , active and bright as a young woman; had severe headaches; went insane a month or two before her death; a careless housekeeper, not orderly but fairly clean; had a son (III-I22) who was for many years a teacher, later a lumberman, and a farmer and a real estate dealer. 2 and 3 , unknown.

Mother's father.-Not known. (12:127, III-43.)

(53) Principal fraternity: $\mathrm{I}-q$, born $\mathrm{r} 890$. When $\mathrm{I}_{5}$ years of age slie left home suddenly, without her parents' knowledge. She went to Baltimore and brought up at the house of a kind-hearted woman who kept her for a couple of days. She was very nervous, cried, and, at first, refused to tell who she was or where she had come from. After much questioning her benefactress learned her mother's whereabouts and brought the girl back. She remained home a few weeks and again disappeared. The mother made no effort to find her on this occasion and accepted the situation philosophically. She later returned home to see her mother, but did not remain. She again returned home at the end of three years from her first runaway, and informed her parents that the doctor had said she had tuberculosis and she wanted to come home to die. Her father asked her why she had run away from home when they were so anxious to keep her and her reply was "Papa, I couldn't help it-something just made me go." She died 3 months later of tuberculosis. $2-\sigma^{7}$, aged 2O; shows none of the defect of his sister and is regarded as a normal and a good boy. $3-0^{x}$, aged 17 years; at school played truant frequently because he did not like school and at i 3 refused to attend any longer. About this time he began to run away from home, remaining away at first only a few days. His mother states that at these times he would be found in the parks or out in the country, hiding behind bushes, hungry, and with clothing torn. At one of these times he remained away a month and was arrested at the end of that time at the instigation of his mother and was committed to a reformatory for 6 months. Once during this period he made an unsuccessful attempt to run away. At the end of his term he was returned home and remained at home for almost a year. He did no work, as his mother thought he was too young. She sent him back to school, but he resumed his old habits of truancy. Finally, he ran away again and his father offered a reward for his return. One 
day a huckster asked him to carry sone apples to a lady's house. 'l"he lady gave $\lim$ a $\$ 5$ bill with which he departed. He was arrested and sent to a reform school. After $2 \frac{1}{2}$ years he was paroled and returned home, whice lee remained about a year and again ran away from home and went to work in Washington, D. C. He states that he ran away from home because he did not like it then, but can not state the cause of his dislike. Scut to an asylunn for the insane, he was discharged as not insane. Is an intelligent negro boy. $4-\sigma^{7}$, aged 15 . 'This boy is beginning to show the sane tendency as his sister and brother. He plays truant frequently and has remained da'dy from home all night on several occasions. His mother, however, attributes this to a dislike for school and fear of punishment at home. 5- $\sigma^{7}$, aged 9, a sehool-boy, well behaved and quite normal. $6-\sigma^{7}, 7$ years, normal. $7-\sigma^{7}$, died at 1 year of tuberculosis. $8-9,2$ years old. $9-\sigma^{\top}, 2$ weeks old.

Father.- "His wife could give no information concerning his family and therefore could throw no light on the probable heredity of the wanderlust from that source. As the man, however, is a sailor by occupation, it is fair to assume that he himself has been possessed of this more or less uncontrollable desire to wander which has exhibited itself in different degrees in three of his children. He is fairly steady in habits, quite as much so as the arerage negro.'

Mother. -42 years old; robust and in fairly comfortable circumstances; slie is of a pessimistic nature, with very little faith in her family. Sibs: $1-q$, normal, no children. $2-\%$, no description.

Mother's father. - His wife left him early on account of his dissolute habits, so she can tell nothing about him. Died of tuberculosis.

Mother's mother.-No description. (1 $3: 21$.)

(54) Propositus, born I 852 ; was a fairly strong young man. In 1872 he married a woman who "likes to travel, so they have becn all over the country." They were married in New Jersey and have since lived in I I places, and not long in any one place. In 1882 when he was living in Kansas, he had typhoid malaria, upon recovery from which he lost all memory of past events and became mentally confused; his mind is now feeble. He has liad repeated blue spells; he would be so depressed that he would, supported by a doctor's advice, pack up and travel for a year. At four different periods he became disoriented and lost his memory during the period of depression. Sibs: $I-q$, died at 1,5 years. $2-\sigma^{7}$, died at 16 years from a gunshot wound while hunting. 3- $\sigma^{7}$, died at 2 years from convulsions. $4-q$, died at 6 years; she had frequent epileptic convulsions. 5- $\sigma^{7}$, has had cpileptic convilsions; is fecble-minded and quick-tempered.

Father.-Showed wanderlust three times and each time wandered off in a confused state; once he went to Kansas to find his son and becane mentally confused and was lost; was then committed to an asylun with senile dementii. Sibs: He had one brother, about whom nothing could be learned.

Father's father.-Quick-tempered, easy-going, had speech defect.

Mother.-Had chronic sick headaches and fainting spells; deternined, energetic, stern, quick-tempered, very religious. Sibs: $1-q$, little known. $2-\sigma^{7}$, a strong, portly man, constable in a New Jersey town for many years; spent the last part of his life in Florida and died there.

Mother's father. - Went to war, got clironic diarrhea, and died, shortly after the war, of tuberculosis.

Mother's mother.-Had fainting spells. (21:232.)

(55) Propositus, 우, born 1875; a big strapping girl; disappeared when 17 years old and never found; a wanderer. Sibs: 1 , died in infancy. 2- $\%$, kind- 
hearted; decent but disorderly and untidy. $3-q$, once a vegetable cook at Waldorf-Astoria hotel, good worker, quick temper. 4-o, unknown. 5-q, queer, nervous, and excitable. $6-\sigma^{7}$, brakeman. $7^{-q}$, was vegetable cook and later on vaudeville stage; now in domestic service.

Falher.-Drank, won a great reputation in walking matches, ran several saloons, deserted wife and large family and lost track of for I I years; had married again.

Mother.-Died under operation for rupture. 'Traits unknown. (36:4I, V 6.)

(56) Propositus, 우, a drinker, formerly ran around a good deal; had a child illegitimately before marriage and another one since; a rolling stone. Sibs: $1-\sigma^{7}$, a feeble-minded tinkerer who helps at various jobs. 2- 5 , a prosperous man who is quick-tempered and has an epileptic daughter. $3-\sigma^{7}$, a heavy drinker. $4-0^{2}$, a drinker.

Father.-A wanderer, tramped widely, worked at anything.

Mother.-Said to have been a good woman. (34:152.)

(57) 'The principal fraternity is that of the patient's mother. None of the 4 women of this fraternity are said to be nomadic, although details are lacking about 2 of them. The only man is a wanderer and a heavy drinker.

Father.-Was a wanderer and inclined to desert his family. He went to war and did not return.

Mother.--Is "of good reputation"; nothing more is known about her or her other relatives. $(36: 50$.

(58) Propositus, $\sigma^{7}$, born 1859 . I,ikes traveling, trading, seeing strangers; now a promoter of newspaper circulation. Sibs: I- + , born I 858; has overpowering headaches two or three times a year, relieved only by discharge of bile from stomach by vomiting. 2-ot, not nomadic.

Father.- "Always liked to travel and said up to his death that if a young man again he would keep traveling"'; occupation, traveling dealer in notions, etc.

Father's father and mother.-Unknown.

Mother.-Not restless; her sibs unknown.

Mother's father and mother.-Unknown. (Col-3.)

(59) Children: $1-\sigma^{7}$, born 1887 ; extravagant, wants to become a bridge engineer. $2-\sigma^{7}$, born I880; good speaker, has wanderlust.

Father.-Improvident; has wanderlust and repressed Bohemian tastes. Sibs: 1- $0^{7}$, improvident, wanderlust.

Father's father.-Wanderlust.

Father's mother.-Domineering, vain, mercenary; at 76 likes jolly companions and dancing.

Mother.-Care of flowers, love of country walks. Sibs: $1-\sigma^{\top}$, erratic. $2-\sigma^{7}$, domineering, resourceful in emergencies.

IIother's father.- Inventive and mechanical.

Mother's mother.-Vain, giddy, superficial, morose, suspicious. (Nas-1.)

(60) The principal fraternity of 9 includes 5 boys and 4 girls. Of the boys, 3 may be regarded as probably having nomadic tendencies. Thus one was "always wild, running about; married, deserted his wife, and has now gone West. He was alcoholic." Another "would work well for a time and then spend all his money, he has now gone II est; is somewhat alcoholic." 'The third is a 
good worker, but a reckless spender; he, too, has gone $\|^{\circ}$ est; is somewhat alcoholic. Of the other two boys one "works steadily, but drinks after liours; quarrels with his alcoholic wife." Since he has renained at lome he probably has no nomadic tendency. "lhe youngest brother is "lazy and a loafer," but there is no evidence of any restlessness. Of the 4 girls one (now is years old) may be regarded as having a vagabond tendency. Very early "she ran out with disreputable girls and stayed out late at night." Arrested for drunkenness and jailed for 3 weeks, she and a companion, securing the aid of some workmen, escaped, but were captured. 'Two sisters apparently have no nomadic tenderscy. one was a sex offender before marriage, but has been studious since and was temporarily insane; the other was very $S x$; driven from her lome by lier husband she keeps house for another man. The remaining daughter is too young to show her traits.

Fother.-Was violently abusive toward his family; sold his wife's farm and ran off with the proceeds; would go on sprees with disreputable women and failed to support the family. I judge him to be nomadic.

Mother.- Is a good factory worker, drinks, and is $S x$. 'The mother's mother was respectable, but the mother's father is "subject to sprees." 'The mother's father is thus a periodic at least; but further details are lacking. (34:362.)

(61) Propositus, E. B., $\sigma^{7}$, born I 887 , finished grammar-school and begged then to be allowed to go into the navy, having a desire to travel and see something of the world. This request being refused, he went to work at telephone repairing; at the age of 20 he entered the nary as an ordinary seaman, worked ont enlistment, was honorably discharged, but has neier since been able to sellle dow'n in one place. He is now working for the Bell lelephone Company, repairing overhead wires, and in this way is able to gratify lis spirit of resllessness and desire to travel; his disposition is quiet and peace loving; he has never married. Sibs: $\mathrm{I}-$ o , born 1884 , completed grammar-sclıool; normally of a high-strung disposition, after a disappointment in a love affair she became depressed, had hysterical attacks, and was finally committed to a State hospital. She has periods of excitement, when she breaks dishes and ornaments; had delusions regarding her proposed marriage (dementia precox). $2-q$, born $1 S S S$, a stenographer of gentle, bright disposition. $3-0^{7}$, born $1 S S 9$, died at $2 !$ years.

Father.-Born 1862 , a printer, proficient in his craft, a good business man, rather nervous. While never a wanderer he is excedingly restless and is never content to remain in one spot for very long; does not spend evenings at liome (but home not congenial). "His manner does, however, suggest restlessness." Sibs: $1-0^{7}$, born in lingland, 1847 ; was of a rowing disposition and as soon as he was old enough took passage on a steamer for Australia in the capacity of assistant steward; he remained in Australia for a number of years and engaged in sheep-raising; lse came to America later and did not remain long, returning to England for a visit; finally he returned to America to make it his home; has been more or less alcoholic in his habits since lis early manhood; never married. $2-\sigma^{7}$, born in London, $1 S_{+7}$; came to this conntry with lis parents and was not content to remain long in one place during his carly manlood; made several trips to England, but finally settled in Olio; a jewcler of cquable disposition and morals; has never married. $3^{-7} \sigma^{7}$, born in London, $1 S_{51}$; canne to the Lnited States with his parents; lias 5 danghters and 1 son, none of whom show nomadism. 4-q, born in London, is 56 ; came to the Inited States with her parents and spent much of her life in Brooklyn; narricel a printer who had a government position in Washington and is now in Newark. She is of a nervous disposition and plays well; leer $;$ datughters and 1 son are not nomadic. 5-9, born in England, is 58 ; came to Anerica with lier parents and has lived in Prooklyn ever since; is nervous but of good disposition: 
married a printer; no children. $6-\sigma^{7}$, born in London, 1863 , is in the realestate business, musical, normal, and of even temper; has two sons, one a little restless and one has had an attack of melancholia. $7-9$, born in London, 1870; nervous but of good disposition; married a printer, childless.

Futher's father.-IV 6, born in London, I8I7; health always good; equable in temper and of good character; emigrated to America and was a printer in Brooklyn; had artistic and literary ability; died of paralytic stroke, I89 I. Sibs: $1-\sigma^{7}$, unknown. $2-\sigma^{7}$, clerk. $3-\sigma^{7}$, printer, born and died in London.

Father's mother.-Born in London, 1831 ; is a charming, well-preserved, intelligent old lady who, at 82 , is quite capable of traveling alone; writes poetry easily.

Mother.-Born in Brooklyn, I864, is of a nagging, fault-finding disposition; has had fits of depression when she would not talk; not very intelligent. Sibs: $I-\sigma^{\top}$, a mechanical engineer by profession, pretty level-headed and of good disposition; after his father's death he "splurged" a good deal with the money left, frequented race-tracks, drank some, but later settled down; has two sons and a daughter who seem to be stable; the other sibs of the mother all died young.

Mother's father.-Born in Vermont of French Huguenot ancestry; quarreled with his father in early manhood, left home, took a new name in order to sever connection with his family; was of a morose disposition, very stern, obstinate, anc a hard taskmaster, fairly successful in business.

Mother's mother.-Born in England, 1833; suffered from "salt rheum" or "scurvy;" was not very quick mentally; after her husband's death she developed melancholia and soon died. Sibs: $1-0$, unknown. $2-q$, very obese. $3-9$, unknown. $4-\sigma^{7}$, plumber, very alcoholic. $5-\sigma^{7}$, printer. $6-\sigma^{7}$, alcoholic. 7-9, died of typhoid. 8- $\sigma^{7}$, followed the sea, drank heavily. $9-0$, has spells of despondency. I $0-\sigma^{7}$, unknown. I I- 9 , egotistic, self-assertive. (13:328, VI 20.)

(62) Propositus, 우 born I 889 ; seamstress, fond of outdoor life, greatly interested in art and music, mild disposition, public-spirited, but more deeply interested in domestic life. At times has a desire to roam. Sibs: $\mathrm{I}-\sigma^{7}$, born I 890, agriculturist, sedate, slow to anger, of clean habits, good memory, fond of good literature. $2-\sigma^{7}$, born 1892 , mechanic, had convulsions until about 4 ycars of age. Slow but certain in action, practica land dependable, athletic. 3- $\sigma^{7}$, born I 894 , agriculturist, quick, alert in action, has a violent temper; is a general favorite among his companions; has keen sense of humor and an easy, care-free disposition; works well under command; has a strong body and good inemory; strong desire to wander; fond of athletic sports, music, and art. $4-\sigma^{7}$, died at 3 years of brain fever. $5-\sigma^{7}$, born i 899 , prefers nature-study and manual training to securing an education; slow but certain in action; loves work with machinery; affectionate and loving, but strong willed; cheerful disposition.

Father.-Born in Germany, I864. Came to the United States at i 9 years; was in Missouri and Wisconsin; was a mason in youth, general farmer, now fruit grower; very fond of outdoor sports, artistic, very fond of nature; a kind disposition; leader in public affairs, keen sense of humor, and fine intellect. Sibs: $1-\sigma^{7}$, born 1 866, sensitive, weak physically. 2- $q$, born 1862, unknown. 3-o, born 1867 ; an unconquerable will. $4-0^{7}$, born 1869 , a careless, care-free wanderer, not very strong intellectually. $5^{-0}$, born 187 , considered a clairvoyant, also very superstitious. $6-\sigma^{7}$, born 1873 , a nervous, quick temperament, a violent temper, easily subdued. $7^{-} \uparrow$, a very cheerful disposition. 
Father's father.-Born I 830 , fond of gay society and somewhat inclined to alcoholism; athletic and a good marksman; remarkable memory. Inclined to be selfish, even brutal, toward members of the fannily and others under his authority.

Father's mother.-Born 1834 and died at 78 years; very energetic; loyal and devoted to all, generous to a fault; a good memory; somewhat superstitious. slow to anger, very brave.

Mother.-Born i 868, very decisive; practical ideas; energetic, public-spirited, courageous; has a desire to be useful to others, and is a lover of nature. Sils: $\mathrm{I}-$ o , unknown.

Mother's father.-Born I 837 , quick in action but of a quict disposition, fond of children, proud of work well done, very practical-minded.

Mother's mother.-Born 1839 , very keen intellect, strong pliysique; just and upright character. (IVic-I.)

(63) $\sigma^{7}$, is an alcoholic of a roving disposition and when last heard from was in the navy.

Father.-Drives an express wagon. Sibs: $1-\sigma^{7}$ was killed in a skirmish witl Indians when 22. $2-\sigma^{7}$, at the age of 20 disappeared from home and has not been heard from since. 3-9, apparently steady. $4^{-0}$, after typhoid fever was for a time maniacal and admitted to State hospital three times; used alcohol excessively; was $S x$; case diagnosed as dementia precox. 5- $0^{7}$, alcoholic. 6-9, little known.

Father's father.-Frequently had delirium tremens. One of his brothers, who married a woman born in Ireland, has a son who is alcoholic and shiftless and never slicks at any one occupation for any length of time. Another brother was erratic in behavior, never stuck to anything for very long; became insane.

Father's father's father.-Probably born in England; was very austere and strict.

Father's father's mother.-No data.

Father's mother.-Deteriorated mentally.

Mother.-Unknow11. (13:124, IV 43.)

(64) Propositus, $\sigma^{7}$, about 50 years of age. Left home at over 20 years and was last heard from in New York City. Had a happy-go-lucky nature, with an adventurous spiril. Sibs: $1-\sigma^{7}$, has a genial, social nature, not irritable, but tense when talking about distressing subjects; not alcolıolic. $2-9$, sociable, fond of a good time; married, but does not live with her husband; talks rapidly and rather jerkily. $3-q$, possibly has neurotic tendencics covered by selfcontrol.

Father.-Has an even disposition; was not irritable or subject to moods; drank some. Sibs: $1-\sigma^{7}$, was in command of ressel and died young at sea. $2-\%$, little known. 3- $\sigma^{7}$, born in Maine, went to Pennsylvania. $t^{-q}$, little known. 5- $\sigma^{x}$, capable farmer of good reputation. $6-9$, not irritable, but over-religious, yet uncharitable and revengeful; langhed "nervonsly." $7^{-}$, never nervous or irritable; clied of tuberculosis of the bowels. $S-\sigma^{7}$, jovial, never down-hearted or depressed, sociable, ligh-strung; at one time was principal of a school, then went on a trading cxpedition to Africa; again a principal, then connected with a publishing-louse and then local manager of a land deal in Kentucky; after wife's deatl drank more and was found dead, possibly a suicide.

Falher's father.-Steady, mucli-respected man.

Father's mother.-No data. 
Mother.-Slightly "nervous;" died at about 55 years of inflammatory rheumatism.

Mother's father and mother.-Unknown. (I0:28I, XI I3.)

(65) Mother's father went into the army but deserted and his mother then gave him some money to get away. He went West, but was captured and returned to the army. Sibs: $1-\sigma^{n}$, not $W .2-\sigma^{7}$, in army and in prison. $3-\sigma^{7}$, steady; his son received stolen goods, but does not seem to be a wanderer; his wife of weak origin; their children: $(a) \sigma^{7}$, steady; $(b) \sigma^{7}$, is very obstinate; left home to become a cowboy at the age of $I 7$ (born I89I); from there he enlisted in the army; is now in Alaska; $(c)$ \& , steady; $(d) \sigma^{x}$, works in a mill; $(e)$ o , I3 years; $(f)+,(g)$ o , young. $4-\sigma^{7}$, not $W .5-\sigma^{7}$, not $W .6-\sigma^{7}$, not $W .7-q$, not $W .8-\sigma^{7}$, was not $W$ but was epileptic. (34:59.)

(66) Propositus, born I 884. Tramp; "drinks like a fish." Sibs: I- $\sigma^{7}$, a tailor for 60 years; deserted wife, was alcoholic and erotic, now of good habits; a weak character. $2-\sigma^{2}$, died in infancy. $3-q$, alcoholic, drank by herself at home, a dressmaker until recently; respectable, orderly, but got "sporty" at times; went out of town with questionable people to hotel dinner-parties, champagne, etc.; may have been sexually immoral. $4-\sigma^{x}$, died of throat tuberculosis, was alcoholic. $5-0^{7}$, about 36 years old, a drug-clerk, very alcoholic, wild. $6-\sigma^{7}$, "simple-minded." $7-\sigma^{7}$, about 40 years old; came to house of brother (2), demanded money, was refused because of drink, broke door of house and left. $8-\sigma^{7}$, died at 25 years (1902) of typhoid; dreamer, imaginative, nervous, weak, erotic, had little resistance to temptation, showed maudlin sentimentality, had a bad color; was a worker in a mill, but was not efficient; made artistic sketches; drank habitually.

Father.-Was a tailor, had a good mind and physique, was never sick, did not drink, was excitable and would quarrel over an argument. Sibs: $1-\sigma^{7}$, neurotic, would easily flare up; was argumentative and active; unnecessarily neat, and drank some; a tailor. $2-\sigma^{7}$, was droll and quiet, had a sense of humor; drank some; was a cooper. $3-\sigma^{7}$, always a rover, had a good mind; was out West near Pike's Peak at time of war; went into the army; was jolly good company. 4-9, married and went West. $5^{-}+$, of sound health; grew deaf as she grew older; died of an accident. 6-9, had a good mind, was active to the day of her death; she had one son living near home, aged 55 .

Father's father.-Was a happy old man.

Father's mother.-A fine Christian woman.

Mother.-Proud, high-minded, lived up to her means; her mind was clear, became senile; was said to have had "cancer." Sibs: I- $\sigma^{7}$, normal. $2-q$, a dressmaker, had tuberculosis. $3^{-9}$, had a good mind. $4^{-9}$, died of tuberculosis at 30 years. $5^{-\uparrow}$, had a good mind; died of hasty tuberculosis. $6-9$, had a good mind; died at 63 years of cancer of the breast.

Mother's father and mother.-Unknown. ( $7: 356$.)

(67) In the (patient's mother's) fraternity of 17 there are 5 males; very little is known about 3 of them, except that they are living on a ranch in Canada. Of the others one has heart trouble and is very thin and excitable and the other was wilful and adventurous as a boy, settling to no definite occupation; always crazy over women, whom he fascinated and brought to ruin; married and moved to a large city, where he lived with his wife for I 2 years, continuing, in the meantime, to seduce young girls. After his wife had borne him 8 children he deserted her and went to California. Of the 12 sisters, 4 died young, one is very imperfectly known, and there is no evidence that any of the 7 others had wanderlust. 
Of the father of the preceding fraternity it is stated that he was quichtempered and domineering, like most of his stock. His 2 brothers appeared to be steady, but one of them had 2 sons, of whom one, after a very irregular life, married an attractive girl of 20 and by her had a son who was migratory and died in Idaho, his body being brought home by a woman of the chorusgirl type who said she was his wife.

Of the mother's fraternity the 4 brothers are all dead and their traits unknown. Of the 6 sisters little is known; there is no evidence of restlessness.

This history is very imperfect. Outside of the principal fraternity there is one nomadic male who is on the father's side of the house, but he is only a grand-nephew of the father and it is quite possible that the tendency came into his fraternity from another source than that of the principal fraternity. $(24: 78$.)

(68) Propositus, $\sigma^{7}$, born in Massachusetts, 1879 , has a wild, roing disposition, wandcring about from one place to another, said to drink excessively at times. Whereabouts unknown at present. Sibs: $1-\sigma^{7}$, born I889; like his brother he wanders aimlessly from one place to another; said to drink excessively and considered altogether worthless. 2- $\sigma^{7}$, born i $88_{4}$, normal. $3-0$, normal. $4-\sigma^{r}$, normal and sociable.

Father.-Born in Massachusetts, 1859; normal man; a Methodist minister; sociable, highly respected; even disposition. Sibs: $1-9$, normal, sympathetic; even disposition. 2- , sociable, highly contented. $3-\%$, sociable, affable, even disposition.

Father's father.-Of even disposition, sociable, well-liked, moved frequently from place to place, but not regarded by the family as unusual.

Father's mother.-A Shaker; quiet, retiring woman.

Mother.-"Normal." (4I : 240, V I.)

(69) Propositus, ơ , born 1888, was constitutionally inferior; would not finish the eighth grade in school, but dereloped wild traits, smoked cigarettes, ran away, would not stay at home, and when he was at home was cross and ugly. On one occasion, at 5 years, he wis gone for oier a month; he had tramped from central New Jersey to Easton, Pennsyliania. Ile has trateded all over the country, has been to Europe, Italy, France, four times. Since 1907 he has been in the army. Sibs: 1 to + died in infancy. 5- $\sigma^{7}$, was ambitionless and did not go through school; was a flagman for the railroad at the time of his death. 6-07, did not graduate from high school; has much musical ability; is learning the electrical business. $7-q$, born 1899 , normal. $8-q$, born 1900, normal.

Father.-Born 1855; unambitious, alcolnolic, mentally inferior; ancestry unknown.

Mother.-Born 1963; did not do well in school; in middle life had depressed spells. Sibs: $\mathrm{I}-9$, died of brain fever at 2 vears. $2-q$, little know11; had 3 clitdren, of whon the son was a "black sleep," had a bad disposition, got in with a bad lot of boys, and died at 20 of tuberculosis. $3-q$, born 1897 ; normal. Six clildren died in infancy.

Mother's father.-Born is 38 , lived constantly near his birthplace; had a strong impulse to drink; was miserly and irritable; hid his money in the cellar of lis house, where it was found after his deatl.

Molher's mother.- Not pliysically strong; lost temper easily, died of tuberculosis. Sibs: $1-q$, nervous, even-tempered, religious, ncighborly. $2-q, a$ sleep-walker, and in childhood constantly falling down-stairs; had migraine at monthly period, with depression. 3-o', had a common-school education; was 
wayward and married young; he drank heavily, became depressed, and committed suicide. (2 I : 570 , VI I 53.)

(70) 'The mother's fraternity comprises 2 males and 4 females. 'The elder brother is a wanderer who goes on sprees; his whereabouts are unknown now. The other brother is also a vanderer, went to the Spanish War, deserted, lived with his wife off and on for 8 years, and in the intervals with other women; is highly neurotic and suspicious and has constantly with him a bottle of whisky. Of the 4 sisters one (the "mother") has migraine and lives steadily at home. She married a restless man ("not a lover of work; is away from home a great deal on outings of various kinds") and had 8 children. None of the 4 sons show wandering tendencies, though two of them are troublesome and lazy, the other two being industrious. One of the 4 daughters is only ro years old, but the other three already show grossly erotic behavior.

The father of the above fraternity (patient's mother's father) is dirty, alcoholic, feeble-minded; he has a brother who lost his mind before his death and had a paranoiac daughter.

The mother, of illegimate origin, is feeble-minded and highly erotic. Nothing is known of her father or sibs. (34:125.)

(71) Propositus, $\sigma^{\nearrow}$, submental, left home when very young and has wandered from place to place. In January igi 4 he was in Portland, Oregon, but letters addressed there in February or March I9I4 were returned unclaimed, so that he had probably gone to some other place since. Sibs: $1-\sigma^{7}$, born I878, and died 1907 of tuberculosis; health poor, so he shifted positions frequently; drank excessively and was $S x .2-\sigma^{7}$, idle, restless disposition, quick-tempered and disagreeable; drinks excessively and is more or less intoxicated half the time. Has lived with 8 different women as their husband. 3- $0^{7}$, died in infancy.

Father.-Born $185 \mathrm{I}$ and died 1907; alcoholic, $S x$, illiterate, intoxicated at least once a week.

Father's father.-Alcoholic, $S x$, violent temper.

Mother. - Sx and alcoholic, unambitious, bold and forward, unrefined, dishonest, untruthful. Sibs: $1-\sigma^{7}$, alcoholic, $S x$, and unambitious. $2-$ o , $S x$ and alcoholic.

Mother's father and mother.-Unknown. (4I : I59, IV 43.)

(72) Propositus, $\sigma^{7}$, came to this country from Ireland; said to have had an erratic, wandering disposition; went to Montana and has not been heard from since. Sibs: $1-\sigma^{7}$, died in infancy. $2-\sigma^{7}$, died at 3 years. $3-q$, jealous, quick-tempered, weak; eventually divorced and married again. $4-q$, in State hospital; dull, obstinate, inclined to wander away; said she saw her father and other friends and wanted to go to them. She is destructive, suspicious, periodically excited. 5 and 6 , $q$ ㅇ, unknown. $7-q$, sociable, loquacious, active, high-strung, irritable.

Father and mother of the above are unknown. (4I: 167.$)$

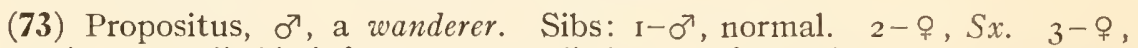
normal. $4-\sigma^{7}$, died in infancy. $5-q$, died at 17 of abortion. $6-q$, a prostitute. $7-\sigma^{7}$, a wanderer and a criminal. $8-\%$, normal. $9-\%, S x$. 10- $q$, irresponsible, has a violent temper. 'There were also 2 sisters and 2 brothers unknown.

Father.-An industrious and amiable man, but weak morally. He has been committed for larceny. Comes from a strain showing criminality and alcoholism and, on his mother's side, of stock showing pathological nervous trouble.

Mother.-Violent temper, not strong mentally; comes from a lax, easy-going strain and one showing lack of judgment. (8: I.) 
(74) Propositus, o7, born in Russia. He served in the army and there is a suspicion that he deserted. As journeyman carpenter, he has wundered over large portions of Germany, Switzerland, and Austria. Came to America 22 years ago and has settled down. By an erratic, hysterical consort he has several children, of whom one, an $S x$ offender, after marriage ran away with another girl for a week. Sibs: $1-\sigma^{7}$, a civil engineer who shows some tendency to wander. $2-\%$, little known. $3-\sigma^{7}$, a physician. $4-\sigma^{7}$, well-to-do leather merchant. $5^{- \text {o }}$, married well. 6 to 8 , little known.

Father.-Born in Russia; served in the army 23 years.

Mother.-A fairly strong woman. (24:74, II 15.)

(75) Propositus, $\sigma^{7}$, born in England and died in Penusylvania. He was a drunken tramp, and no one ever knew where he was. Sibs: $1-q$, born in England; in spite of the fact that her husband is a worthless drunkard, she is kind and pleasant to him. 2- $\sigma^{7}$, born in England, became a heavy drinker rather late in life; before that was pleasant, but is now irritable and disagreeable; at present is in Detroit. $3-\sigma^{7}$, born in England; married and went West and all track of his whereabouts have been lost.

Father.-Born in England and died in Pennsylvania. Ugly temper; did not work for many years before his death, though comparatively healthy.

Mother.-No data, except born in England. (28:43I, II I 5.)

(76) Propositus, $\sigma^{7}$, restless, dissatisfied, always roving away from home; a wanderer. He would stay away for months. Finally a position was secured for him in the U.S. Navy, where he is at the present time, a petty officer.

Father.-Unknown.

Mother.-Neurotic, always nervous from childlood, but otherwise normal. Sibs: I- + , had Huntington's chorea and developed manic-depressive insanity. $2-\%$, became insane during mellopause.

Mother's father.-Unknown.

Mother's mother.-Had Huntington's chorea and became melancholic; liad periodic attacks of insanity. (15:520, XI I 56.)

(77) Propositus, or, born I86I; at 24 began to lose ambition and would not work; seemed melancholy, and had hallucinations of sight and hearing. He would masturbate continually. He would wander away from home and stay days at a time, exposed to all kinds of weather and to hunger. Is now in State hospital for the insane; is very suspicious. Sibs: $1-\sigma^{7}$, very nervous, alcoholic, and in his youth $S x .2-\sigma^{7}$, always quite normal and very intelligent. 3- $\sigma^{7}$, ran away from home when a young boy and has never been heard from since; said to have been incorrigible. $4-\sigma^{\pi}$, seemingly normal, though very alcoholic.

Father.-Always normal, but rather alcoholic.

Mother.-Not in any way neurotic. Is alive at present at the age of $\mathrm{S}_{5}$ and is physically and mentally strong. (25:179, VIII 52.)

(78) Propositus, or, present residence not known. He is a tramp and a worthless drunkard. Sibs: $1-\sigma^{7}$ (patient), at it months was paralyzed; was alcoholic; when admitted to State hospital statement was made: "for several years has wandered around and been unable to look ont for himseli:" $2-\sigma^{7}$, first symptoms of mental disturbance at 19; becane very restless: adnitted to State lospital (cause, dementia prccox). 3- $\sigma^{7}$, unpleasant and ugly. $+\sigma^{7}$. became insane (chronic mania); has religions delusions; inclined to be vicions.

Father.-Born in Ireland and died in Penusylvania; a heavy and continuous drinker. 
Mother.-Health good; not thought to be nervous, yet thought to be a "household shrew." Sibs: I- $\sigma^{7}$, born in Ireland and died in Pennsylvania; health and habits good. $2-\sigma^{\gamma}$, died in Ohio, a fireman. $3-\sigma^{7}$, admitted to State hospital; had short periods of excitement, when he was cross and profane. 4- $\%$, sharp and decided. 5- $\%$, no data.

Mother's father.-Born in Ireland and died in Pennsylvania. Came to the United States in I860.

Mother's mother.-Little known. (28:487, III 5.)

(79) Propositus, $\sigma^{7}$, is a wanderer. Sibs: $1-\sigma^{7}$, a quiet, sober painter for the railroad. $2-9$, a quiet, neat, hard-working woman. $3^{-9}$, no data. $4^{-\sigma^{7}}$, is a driver, drinks and abuses his family. 5- $\sigma^{7}$, a gardener. 6- $\sigma^{7}$, a machinist who lives in the West.

Father.-Honest and agreeable. Died of tuberculosis; belonged to bad stock.

Mother.-Died of typhoid pneumonia and hemorrhage. (34:51.)

(80) Propositus, or, born I864; address unknown; a wanderer. Sibs: $\mathrm{I}-\mathcal{Q}$, died of tuberculosis. $2-\sigma^{7}$, born in Ohio; has a good business ability; he married a strong woman who was born in Ohio. Her sibs: (1) $q$, married and lives in Iowa; (2) 우, died of typhoid fever at $23 ;(3)$ 우, died at 39 of locomotor ataxia; (4) 9 , died at 2 I of typhoid fever; (5) 우, died of erysipelas at 39; (6) $\sigma^{7}$, a wanderer; (7) 우, lives in Iowa; (8) $\sigma^{7}$, died of tuberculosis at 20 ; (9) $\sigma^{7}$, nervous; (10) + , subject to headaches, very nervous; ( I 1) o $\sigma^{7}$, a financier. Her father born in Ohio; at 16 removed to Illinois, where he remained until he was 26 ; spent rest of his life in Iowa; was a carpenter and joiner and a farmer. Her mother was strong physically-children: $(a) \sigma^{\gamma}$, about 25, who has severe headaches; $(b)$, not very strong physically, married and lives in Kansas. 3-q, very fleshy, married and lives in Nebraska. $4^{-q}$, mathematical ability. 5- + , fleshy; married and lives in Nebraska. $6-q$, fleshy; married and lives in Iowa. $7-\sigma^{7}$, died of kidney trouble; had business ability. $8-\sigma^{7}$, lives in Oklahoma. $9^{-7} \sigma^{7}$, lives in Northern Mexico. In addition there were 4 stillborn.

Father.-Born in Ohio; at 27 moved to Iowa; was a farmer all his life.

Mother.-Born in Ohio; ambitious for wealth; very fleshy, but strong and healthy. (Dud-r.)

(81) Propositus, $\sigma^{\top}$, engaged in farming and lumbering. Has a roving disposition and is not much of a lover of home. Sibs: $1-q$, very industrious. $2-\sigma^{7}$, a farmer, who has a "fierce temper," but is a great lover of home. $3-\sigma^{7}$, a farmer and school-teacher; a home-lover. $4-q$, died in infancy. $5^{-0^{7}}$, no data. $6-\sigma^{7}$, died in infancy. $7-9$, no data.

Father.-Industrious farmer. None of his sibs stated to be wanderers.

Father's father.-Farmer and miller all his life; had excellent memory.

Father's mother.-I,ittle known.

Mother.-Little known. Sibs: $1-\sigma^{7}$, stammered. 2- $\sigma^{7}$, very pugnacious, died of paralysis. $3^{-\sigma^{7}}$, died of apoplexy.

Mother's father.-Farmer and school-teacher.

Mother's mother.-Died of an abscess on the liver. ('Tra-2.)

(82) Propositus, ơ; unmarried and wild; ran away with the circus. No other data given. Sibs: $I-\sigma^{\top}$, age 30 , a mechanic, is wild and gambles. $2-\sigma^{7}$, lives on a farm; is unmarried; is like an old man. $3-\sigma^{7}$, is unmarried, lives on a farm. $4^{-}+$, was always wild and $S x$. 5-8, "nicest of the lot;" a strong character. 
Father.-A liquor-dealer.

Mother.-Died of tuberculosis at 57. Sibs: $1-\sigma^{7}$, went to war and was confined in Libby Prison; he could endure no liquor; naturally a steady man and a good worker. 2- $\%$, has headaches and rheumatism. 3-q, died of apoplexy at 59. $4-\sigma^{7}$, died in infancy. $5-\sigma^{\top}$, age 59. 6- $\%$, a good respectable woman who had goitre. $7-0$, died in infancy. $8-\sigma^{7}$, lives on farm and drinks some. $9-\sigma^{7}$, a hard drinker. 10-\%, had a fall when a young girl; goes from one subject to another; has no judgment. I I $-q$, strong and well-looking.

Mother's father.-Moderately alcoholic; died of paralysis and dropsy.

Mother's mother.-A strong, hard-working woman, who was very much against liquor. $(7: 347, \mathrm{~V} 45$.

(83) Propositus, $0^{7}$, has gone off. Sometimes they do not know where he is. Has separated from his wife. Sibs: $1-q$, no data. 2, died in infancy.

Father.-In piano business.

Mother.-No data. Sibs: I- $\sigma^{7}$, a farmer. 2- , died of apoplexy. $3-\%$, burned to death. 4- 4 , an inventor of driven wells. $5-\sigma^{7}$, an inventor of a plow for railroad, "always just going to do great things." $6-\%$, died at 35 of tuberculosis. $7-\%$, died at 55. 8- $\sigma^{7}$, a clergyman, became insane.

Mother's father.-An inventor; died in a railroad accident.

Mother's mother. - A spiritual woman, much beloved. (7:379, VI 21.)

(84) Propositus (patient's brother), is an alcoholic, roving sailor; his address is never known. Sib: $I-\sigma^{7}$ (patient), says he came to this country at 14 with a man cousin of his mother; as he is an acknowledged "liar," it is difficult to take his word; he is a hopeless drunkard; has threatened suicide; goes roaming about at night.

Father.-It is stated that the mother separated from him because of his drunkenness.

Mother.-Born in England; little data; died in the United States of cancer; none of her sibs stated to have been wanderers, but one brother was alcoholic.

Mother's father.-A miller in England.

Mother's mother.--Respected. (7:394, III I.)

(85) Propositus, was quict, but always of nervous temperament and formerly had nervous exhaustion; wonld wander off whenever lie felt like it. Is seldom heard from by the family; wanders from place to place, tramping it. Sibs: $1-q$, born 1869 , in Massachusetts, suffers from nervous exhaustion and hypochondriasis; has dizzy spells. $2-\sigma^{7}$, born 1870 ; precocious at school; became quiet, uncommunicative; at 20 began to worry about affairs at home, as his father had died; did peculiar things; would go off into the woods and stay a day at a time; for 2 years before commitment would rarcly answer questions nor notice his sibs; he would go out into the yard and run round and round a post-this he would do 2 or 3 times a day. 3-9, dicd at 16 ycars of tuljerculosis. $4-\sigma^{7}$, born I877; worries over small things; is of average intelligence and ambitious to rise in trade of shocmaker; he goes from one company to another. thus hoping to improve his standing. $5-\sigma^{7}$, born 1879 ; checrful, sociable, self-sacrificing. $6-\sigma^{7}$, born 1887 , at home, donestically inclined: always rery ambitious, regretted that he could not get a better education; worried about not getting work; had hallucinations and delusions of personality.

Father.-Born about i 842 ; at 19 years, in Civil War, began to drink, thereafter had drinking spells of from I to 2 weeks' duration, at intervals of about 6 months. Epileptic scizure while in war. At fo years had another convilsion, and thereafter about once a year; in last 3 or 4 years of life 3 to 4 times 
a year. Had blue spells. Killed on track by express train. Sibs: $1-\sigma^{7}$, deliberate, worried; was more or less of a shut-in personality; obstinate; a daughter and a son have sick headaches. 2- $\sigma^{\top}$, drank heavily. 3-\%, of an even disposition; made friends easily; was capable.

Father's father.-Drank and had shaking-spells thereafter.

Father's mother.-Good health.

Mother.-Worries about family affairs; has reserved manner and average intelligence. Sibs: $\mathrm{I}-\mathrm{O}^{7}$, farmer; depressed at 40 ; gradually became eccentric, suspicious, and had delusions of persecution; talked to himself; preached when alone in the fields; dementia precox developed.

Mother's father and mother's mother.-Unknown. (Io : I IO, III ir.)

(86) Father of patient: born 1840 : at I 4 ran away to sea and went around the world. After several years he was found and brought back by lis father, but soon left again and went to California via Panama (in those days a dangerous journey), where he worked in the mines; then he went to war; since the war he has been subject to violent headaches. He worked in the mills, but has done nothing the last 15 years. He married at 25 and has hardly left his New Hampshire village since. Says he has seen all there is to see. His time is spent at home in the house, usually doing nothing; sometimes he will sit for 3 hours in the woodshed with his chin in his hands. He often sits silent a whole afternoon. He will not ride in a train, but walks 8 or 10 miles to surrounding towns if he is summoned in case of death of a relative or some equally important matter. His daughter (patient) had dementia precox, and of her brother, a clergyman, the hands tremble violently, especially if excited. He is high-strung, determined, egotistical, selfish.

Fat'ler's sibs: $\mathrm{I}-\mathrm{O}^{x}$, died in Civil War, unmarried. 2-o, unmarried. 3-9, married and died in childbirth; had one daughter who died in the West, leaving I child. 4-o, several children; lives in New Hampshire; she was eccentric, silent, submental; became infatuated with a drinking, good-fornothing man, ran away with him, and died. $5-\sigma^{x}$, died at 16 years of typhoid. $6-\%$, married and had one son, a good reliable worker; drinks some, but is not overcome. $7-\%$, married, but had no children.

Father's father.-Captain of the State militia; a man of strong character and personality.

Fcther's father's sibs:-1- $\sigma^{7}$, a shoemaker; considered eccentric because he always stayed at home and was uncommunicative. $2-\%$, died at ig years. $3^{-\sigma^{7}}$, a mechanic; died at 78 years. $4-q$, died at 61 of dysentery. $5^{-q}$, died at $60.6-\sigma^{7}$, living. $7-\sigma^{7}$, died young.

Father's mother. - Was admitted to the State hospital in 1843 at 35 years of age; became noisy and violent, is now still and melancholy; sits or stands as she is placed; does no work; has attempted suicide; had a brother, unknown; her father was insane. (I I : 7.)

(87) J. M., used considerable liquor by spells; has an uncontrollable restlessness, a sort of inability to stay with work and his family and neighbors. (Ancestry unknown.) (I $2: 86$, IV 25.)

(88) Propositus, $\sigma^{7}$, a good deal of a vagrant, but seems to be fairly bright; married, and with his family moves from place to place. Sibs: $1-\%$, died in infancy. 2- $\sigma^{x}$, born 1859 ; lives alone; unmarried. $3-\sigma^{7}$, unknown. $4-\sigma^{7}$, not bright. 5- $\sigma^{7}$, drowned at 9 years. 6-q, unknown. $7-\sigma^{7}$, odd, but a money-maker. $8-q$, died at I year of measles. $9^{-} q$, died at 8 years of diphtheria. 10-9, unknown. II $-\sigma^{7}$, wanders around the country; married, but living apart from wife. $12-\sigma^{7}$, is a farmhand and drives a milk-wagon. 
Father.- "Not very bright."

Mother.- "Not very bright."

(Of 5 children of propositus, 4 boys and I girl, none are recorded nomadic.) (14:33, IV 23.)

(89) Principal fraternity: I $-q$, born I 852 ; committed suicide, which lier son also is impelled to do. $2-\%$, was the town prostitute; married, untruthful. 3- + , stayed at home; probably licentious. 4-o , self-controlled. 5- , prostitute. $6-q$, died at I year of infant diarrhea. $7^{-q}+$, lias a reputation for immorality. 8- $\sigma^{7}$, drank heavily, had a wandering lendency, and was erratic like his brother. 9-9, a dwarf; had periods of being very nervous. 10- $\sigma^{7}$, extremely erratic; his early life spent in wandering from place to place in the I'est, does odd jobs; has exaggerated opinion of his oratorical powers. I $1-q$, died at I I years of diplitheria. I $2-q$, died at 9 years. $13-\sigma^{7}$, died in infancy.

Father.-Born I826; was part Indian; a farmer; stingy, stole honey, and was committed to State prison therefor.

Mother.-Born 1834 ; a prostitute, even after marriage.

Mother's father.-Died in the Civil War.

Mother's mother.-Unknown. (14: I 12.)

(90) Propositus, or, has periodic spells of drinking and wanderlust. He is a mechanical genius, indolent, and careless in providing for his family.

Father.-Born I8I8, has a mild, even temper and a rather weak intellect. Sibs: $\mathrm{I}-\%$, choreic and insane. $2-\sigma^{\top}$, alcoholic and insane.

Mother (cousin of father) born 1822 and died of pneumonia. Sibs: $1-q$, unknown. 2-o, feeble-minded; had a son who is a hermit and refuses to meet anyone. $3^{-\%}$, insane. $4^{-\%}$, choreic and insane. $5-0^{7}$, choreic and insane; has a religious mania. $6-\sigma^{7}$, nervous. $7-q$, unknown. $8-q$, miserly. $9-0^{7}$, unknown.

Mother's father. - "Born I 787 , died I $\$_{42} ; "$ was probably choreic. Disposition unknown.

Mother's mother.-Cousin of some grade of her husband. (15:654, VIII 105.)

(91) Propositus, H. '1'., o', born 1863; excessively alcolıolic; a wanderer. Sibs: I - 9 , had nervous prostration I I years ago; still on edge of nervous breakdown. 2-o, unknown. 3- + , normal. $4-\sigma^{7}$, died in infancy of water on brain.

Father.-Works in navy-yard, musical, high-strung, excitable, excessively alcoholic.

Mother.-Nervous temperament. (17:729.)

(92) Propositus, J. W., o7, shoemaker; very alcololic; never worked steadily nor told the truth; always worthless. Is wandering now. Is also peddling, it is thought, though the family has lost sight of him. Sibs: $1-\sigma^{7}$, born 1859, died in infancy. 2- $\sigma^{7}$, born 1861; developed delusions; now in State hospital for insane. $3-q$, a domestic, lier word is unreliable; sle is changeable. 4- $\sigma^{7}$, was always wortlless and dissolute; ran aic'a from home when young, came back with a wonnan whon he clained as his wife; was always alcoholic; shot and killed himself. $5-5$, very alcoholic and worthless; hanged himself, probably while under the influence of alcohol; was "very queer." $6-9$, a nun, is very nervous. $7-q$, bright young woman of small stature, subject to spells of depression. $8-\sigma^{7}$, has spells of sitting, looking off into space; queer delusions, easily led, probably syplititic. 
Father.-Born 1835; shoemaker, drank to excess before his death in 1886 ; was very peculiar. Sib: $\mathrm{I}-\mathrm{O}$, always thought queer by the family.

Father's father.-Somewhat alcoholic.

Father's mother.-Unknown.

Mother.-Very strong.

Mother's father and mother.-Unknown. (17 :2362.)

(93) Propositus, or, a prospector. Went to Cape Town, South Africa, and not heard from in years. Sibs: $1-\sigma^{7}$, went to Mexico, not heard from since. $2-\sigma^{\top}$, in news business; killed by a train. $3-q$, in State hospital for insane. 4-o , deaf.

Father.-Unknown.

Mother.-Lost memory, refused to eat; of nervous temperament; religious. $(17: 2563$.

(94) Propositus, o7, has always been alcoholic, drinking whenever he got the chance. Now at 73 he has developed insane ideas, of which one is to travel all over the country on a bicycle. He is active, restless, and on the go all of the time. When not riding his bicycle, he will walk for hours at a time. He has 2 sons, neither nomadic, but one alcoholic. Sibs: $1-q$, born 1827 , is nervous, quicktempered, determined, no special sickness. $2-q$, died of cancer. 3- $q$, died of consumption. $4-q$, died in convulsions at 7 years, of congestion of the brain. 5- $\sigma^{7}$, a nervous man, not worth much, without energy, and yet he was married three times. 6- $q$, unknown. $7-q$, a nervous, cranky woman; deformed on account of infantile paralysis (?).

Father.-A poor, worthless drunkard; submental; froze to death.

Mother.-Well and strong, lived to be 88 years old. (2 I : 19, II 21.)

(95) 'The father, born 1865 , left home early, has wandered almost continuously and has not often communicated with his relatives. After leaving school he worked at various things, but never stuck to anything. By his own statement has at various times worked on the railroad in different capacities; also at carpentering and soldiering. After his first wife died he began to wander more than ever; has been in every State of the Union except three; also in Europe and Australia. He enlisted in Cuban $W a r$. He is $S x$ and has a violent temper.

Father's mother.-Was peculiar, subject to fits of temper and hysteria.

Mother.-An $S x$ and filthy woman.

Mother's father.-Alcoholic.

The children of the above father and mother: I- $\sigma^{7}$, born 1899; fond of school, but lazy and quick-tempered like his father. 2-o', born I903; at asylum school. $3-q$, born 1907; at orphan asylum. 'Two others still young. $(32: 170$.

(96) Propositus, $\sigma^{7}$, born $18_{55}$; of a roving disposition. Lived with a woman, deserted her to live with another in Buffalo (home in northwestern Pennsylvania). Sib: 우, ran away from home and got married at 14 ; broods. Father.-Worthless; worked at farming, maintaining a squalid home.

Mother.-Entirely unknown. (28:71, IV 39.)

(97) Propositus, $\sigma^{7}$, is of a roving disposition. Sibs: $1-q$, married, not a wanderer. $2-0^{7}$, farmer. 3 to 7 not $W($ ?).

Father.-A prosperous farmer. Sibs: 1-q, died young. 2- $\sigma^{7}$, unknown. $3^{-}+$, lived in Kansas. $4-\sigma^{7}$, lives in Pennsylvania. $5^{-0}$, died at 18 montlis. $6-\sigma^{7}$, died at 3 years. $7-\sigma^{7}$, miner. $8-9$, died at $2 \frac{1}{2}$ years. 
Mother.-A strong-minded woman. Her sibs and parents unknown. (28:297, IV 33.)

(98) Propositus, when 18 or 19 left home and nothing was learned of him for 4 years, when a letter was received from South Americu. Nothing more was heard for 20 years, when he returned to the United States with a wife and family, having lived in South America for most of that period. Sibs: $1-\sigma^{7}$, born I 824; was a periodic drinker, but temperate in last years of life. 2- 9 , born 1832 , healthy. 3-o , nervous, subject to outbursts of temper, soon over. $4-\sigma^{7}$, drank to excess, always nervous, drank between jobs when he was out of work. 5-o, born 1842 , calm, even-tempered, frank. 6-q, born 1821; healthy, without nervous disorder; married a lazy, shiftless man, who was abusive and incompetent; there were 3 children who survived infancy: (a) $\$$, born I 855, unsocial, unreliable in statements, violent in her judgments; had an epileptic child. (b) o , born I 857 , erotic, fraudulent, higlsly untruthful, ugly. (c) ơ, born I853, big, blustering man, who says he works pretty steadily except 3 or 4 months of the year; decidedly untruthful; tells imaginary tales; not nomadic.

Father.-Stonemason; quiet.

Mother.-Healthy, without mental trouble. (28:788, II 4.)

(99) Propositus, $\sigma^{7}$; illegitimate son of his mother. Is a fireman, has always been of a roving, discontented disposition.

Father.-Unknown.

Mother.-Born in Germany, I862; epileptic; seizures always introduced by an outburst of temper. Sibs: $\mathrm{I}-\sigma^{7}$, born 1857 , farmer; las worked for one man a number of years, is steady and thrifty. $2^{-}+$, unknown. $3^{-q}$, quicktempered but well liked; I son, steady.

Mother's father.-Born in Germany, 1828 , and died, 1894, in Pennsylvania; always a heavy drinker, became intoxicated occasionally; was a laborer both on the farm and on the railroad.

Mother's mother.-Epileptic. (28:1284, III 16.)

(100) Propositus, $\sigma^{7}$, born in Pennsylvania, 1S78; as a child, stubborn and difficult to manage; never got along very well with teachers and pupils at school, and finally left against his parents' wishes, but was not considered backward. He learned the blacksmith's trade, but never reully' stuck to that or any other occupation for any length of time. He was naturally of a rosing. restless disposition, and the desire to cut loose from his family and wander off somewhere manifested itself particularly in the spring. 'The sister told an incident to show how inevitable this feeling was. One day as a friend of the family stood near the window he observed casually that spring must be coming, for he could hear the bullfrogs croaking; a sister of the patient immediately" spoke up and said, "I hope to goodness WVilliam doesn't hear them, for he'll be off immediately if he does." IVilliam has not lived at home for to years. He often became intoxicated. For a time he lived with lis sister in $\mathrm{E}$ - - but he went IVest and nothing has been lieard of him since. Sibs: $1-\sigma 7$ (patient), neurasthenic ideas, delusions of an autopsychic nature; frequent migruine: his disposition changed; he gained delusions of influence, becane a dementia precox, is now in State hospital. $2-\%$, died in infancy. $3-q$, born 1850 , normal. $4-\sigma^{7}$, of temperate habits, not nervous. $5-\sigma^{7}$, died in infancy. 6-9, normal. 7- 7 , born I889; feeble-minded since birth; is irritable and disagreeable at all times. $8-q$, born 1892 ; seems normal. 9 - + , normil. 
Father.-Irritable and moody; liable to outburst of temper; gets depressed; is never intoxicated. Sibs: $1-9$, normal. $2-\sigma^{7}$, born 1846; school-teacher; no evidence of neurasthenic traits. 3-q, little known.

Father's father.-Temperate.

Father's mother.-Health good.

Mother.-Born I 852; not mentally quick; has loving and good disposition; occasionally confused. Sibs: $1-q$, died at 30 years, little known. $2-\sigma^{7}$, a hard drinker until 25; now abstaining. 3-9, good health. 4-9, normal. $5-\sigma^{7}$, occasionally drinks, sometimes to excess. 6- $\sigma^{7}$, a periodic drinker, indulging rather heavily for 2 or 3 days every 2 or 3 months, but taking little or nothing between times. $7-9$, little known. $8-9$, had chorea as child, but now normal. $9-\sigma^{7}$, an occasional drinker, sometimes to excess.

Mother's father.-Occupation a molder; until rather late in life he would go on sprees which lasted about a week; these occurred once or twice a year. Full of fun and loved to tell amusing stories.

Mother's mother.-Normal; childish and forgetful in recent years. (28:1312, III-6.) 


\title{
INHERITANCE OF TEMPERAMENT
}

\author{
With Special Reference to Twins and Suicides
}





\section{INTRODUCTION.}

In this paper an attempt will be made to analyze the distribution in families of temperament or its expression in mood; and to test the hypothesis that it is dependent upon hereditary factors.

We recognize a certain average of normal temperament, and that, in many persons, the mood is often associated with an increased activity and elated emotional tone; in others with a decreased activity and lowered emotional tone; while still others pass through alternating cycles of hyperactivity and depression. Let us consider these states in greater detail and seek to define them. ${ }^{1}$

\section{DEFINITION.}

\section{THE HYPERKINETIC STATE.}

This is an emotional state in which one or more of a series of elements of behavior are shown, of which the following list has been given by Southard (1914, p. 630): đestructiveness, exaltation, homicidal acts and threats, irritability, psycho-motor excitement, and violence. Whether all, or only some, and then which, of these clements shall actually appear in the subject's behavior depends no doubt upon inheritable differences in the nervous mosaic. Now, what the intrinsic cause of hyperkinesis is we do not know, and indeed, we have no ground for assuming that there is any one cause. Southard has pointed out that in nearly every case of reduced optic thalamus the patient has showed hyperkinesis, but it does not follow that this structural peculiarity is always found in cases of hyperkinesis. As Southard say's:

"It is conceivable that somebody will show that simple functions (atrophies, aplasias, agenesias) of the spinal and bulbar gray matter can be correlated with hyperkinesis. Again, somebody may prove that cortical simplifications, either on the impressive or on the expressive side of the apparatus, are correlated with hyperkinesis. 'The fact would probably remain that an entirely normal nervous system-i.e., intrinsically normal-would also permit hyperkinesis under various chemical, physical, or other conditions."

Such other conditions have, indeed, been found, since hyperkinesis is usually associated with reduced blood-pressure. Thus, Dawson (I900) concludes that "the characteristic feature of the general circulation in excitement and probably in exaltation is low arterial tension

\footnotetext{
'The material upon which this paper is based is that deposited at the Fingenies Recurd Oflice founded by Mrs. Ji. H. Harriman and located at Cold Snring Harbor. Jong Island. New York. Many of these data were furnished voluntarily by members of the fanilies enncerned. By far the greater part, fowever, is derived from the reports of specially traised "engenics field-worhers" placed with State institutions through an arrangenent for which funds were given by Mr. Julu 1 ). Rockefeller. Only througl the aid of both Mrs. Marriman and Mr. Rockefeller has this study been possible. Mention should he marle also of the assistance of Miss Mabel l.. larke. who supptied all of the abstracts of the cases on twin infueritance, and of Mise Mary" Thender, who prepared the cluarls and legends ancl checked all caleulations
} 
which helps to maintain, if it does not cause, the mental state." And the blood-pressure, we know, is in turn influenced by fluctuations in the amount of certain internal secretions in the body, especially "suprarenin" or "adrenin" from the suprarenal glands. ${ }^{1}$

Rosenfeld (I9I3), who has gone rather thoroughly into the matter of the relation of somatic disturbances to manic depressive insanity, finds disturbances of emotions "due to arteriosclerosis, Buedon's disease, vaso-motor neuroses, blood-gland disease, disturbances due to vagotonia, heart trouble, and the circulation psychoses." Evidently the normal mood must be conditioned within very narrow limits, so that the remarkable thing is that so many have the normal mood, not that so few have. However, the important point is that all of these conditions-small thalamus, reduced blood-pressure, and the restacting in an hereditarily predisposed organism, produce, as a more or less periodic end result, an absence of the normal inhibitions; so that the individual reacts with unwonted or extraordinary violence to a given stimulus.

Such a hyperkinetic tendency is frequently associated in the same individual with depression; and hence arises the so-called manicdepressive psychosis, of which more anon; but the important point for us now is that this association is by no means universal or even the usual thing. Repeatedly, do we find in ordinary life persons who show constant elated traits; they are very busy, restless, ambitious, scheming, original, sociable, talkative, "always jolly," enthusiastic. In more extreme cases they are erratic, "changeable." For example, the father in No. 2 "never stuck to anything very long and was constantly sinking money in one line of business or another, never making anything of it." They are often braggarts, conceited, profane, hypererotic, brutal, and have fits of violent temper. In a word, they show in some degree the characteristics of the feebly inhibited.

Such persons are not always in the elated state; they may for longer or shorter periods be quite average in their reactions, at times they may even show a depression; but the prevailing mood is a hyperkinetic one and their ordinary depressed state is typically that of calm, quiet, and tractableness which is usually regarded as more desirable from a social standpoint.

\footnotetext{
${ }^{1}$ Upon the subject of adrenin and blood-pressure Cannon and his pupils have recently made a series of most important studies, admirably summarized by Cannon, 19r5. It is shown that under einotional stress impulses are discharged along sympathetic pathways, of which the effect must be to stimulate the heart to more rapid action; and the discharge of adrenin tends to heighten these effects. Every physician is aware of the danger of excitement to persons with degenerated and weakened arteries, doubtless due to their walls giving way under increased pressure. There seems, at first, to be a conflict between the suggestion of Dawson that low arterial tension may cause mania and the findings that high arterial tension follows excitement. It is to be kept in mind, however, that the excitement of mania seems to be mainly of endogenous origin as contrasted with induced excitement in "normal" persons. It is conceivable that low artcrial pressure is the endogenous cause of a state (excitement) which has this end result that it tends to restore the normal blood-pressure, though it actually often causes an excessive pressure. The subject of blood-pressures before, during, and after maniacal attacks seems to require further study.
} 
It will be convenient for us to distinguish two grades of the hyperkinetic temperament, a lesser and a greater, and we may apply to them the two terms which were used in the older psychology but seem to be, at the present time, almost abandoned. The less of these grades is called nervous (sometimes sanguine), the more developed grade is called choleric. To give again and in summary some more or less precise notion of the content of these terms as used in this paper, I may say that the nervous person is active, energetic, irritable, excitable, ambitious, given to planning, optimistic, usually talkative, and jolly. 'The choleric person is over-active, starts on new lines of work before completing the old, brags, is usually hilarious, hypererotic, often profane, liable to violent fits of anger, brutal, destructive, assaultive, and even homicidal.

\section{THE HYPOKINETIC (DEPRESSED) STATE.}

This is an emotional state in which the elements of behavior are on the whole the opposite of those shown in the hyperkinetic state. This state is characterized by psycho-motor retardation; all movements are slow and made with difficulty. The hypokinetic individual seems unable to initiate movements, or does so with difficulty. Thought and action are retarded; the emotions (in contrast with those of the hyperkinetic) are unbroken and stable, but relief is often in tears. Anxiousness, brooding, worry over trifles, fear of organic disease and of impending death, and other painful mental states are present. A sense of self-insufficiency and unworthiness and deep sinfulness often develops, with or without hallucinations. There is usually a high blood-pressure. If the hyperkinetic seem to lack inhibitions so that the mental machine runs wild, the hypokinetics are over-inhibited. The brakes are on too hard, and the emotional machine can hardly work at all. This state, like the hyperkinetic, is frequently (usually in young persons) a transitory one; and in the course of days or months the normal mood is restored.

As with the hyperkinetic, so with the hypokinetic, two states, borrowed from the old psychology, may be recognized. The phlegmatic temperament is characterized by quictness, seriousness, conservativeness, pessimism. The person of melancholic temperament is unresponsive (often mute), lachrymose, given to worry, weak and incapable, feels life a burden, often longs for death as a relief.

\section{THE ALTERNATION OF HYPERKINESIS AND HYPOKINESIS}

It is common to find persons whose mood varies greatly, from grave to gay. At one time they will be very active and sociable, jolly and self-confident; at another they will be plunged into the slough of despond and feel quite incapable of doing anything. Examples of this type are found among men of genius as well as among others. I'or example, the first biograply I pick up is a life of Harriet Beccher Stowe (Fields, I $\varepsilon_{9} 8$ ). At the age of 16 years she wrote her sister: "I 
don't know as I am fit for anything and I have thought that I could die young, and let the remembrance of me and my faults perish in the grave. *** You know how wretched I often feel, so useless, so weak, so destitute of all energy." At other times she was extremely energetic and effective.

Very clear is the description given by Geoffroy (I86I) of a member of the Institute of France who shows the two moods. In the hypokinetic phase he enters the room of the Institute "without saying a word to his colleagues, goes to his place, appears sad and downcast, indifferent to all that is said and never speaking." When, on the contrary, he is in the hyperkinetic phase "everyone notices his entrance, he talks to all, goes from place to place, speaks at each instant, constantly makes objections. After he has reached his home his activity continues. He writes continuously and dictates numerous memoirs to two or three secretaries whom he has under orders." Here the alternation is from a phelgmatic to a nervous mood.

When the moods are extreme we have typical manic-depression or circular insanity. One example is cited by Hammond (I883, pp. 57 I, 572). A man patient of his, 27 years old, "when suffering from melancholia, took no interest in his affairs, but left everything to his partners to manage. It was impossible to rouse him sufficiently to get him to look into matters, and, when his advice was asked, he either gave the first reason that occurred to him or declined to express an opinion." But in the elated state "he was meddling in all departments of the business, suggesting this thing and the other, making extensive purchases without consultation with the partners, and selling things at less than cost. He even rented an adjoining building, so as to be ready for an extension of the business, which he proposed to make in a short time. At home, there was fully as great a change noted." Here the alternation is between states which, while not extreme, approach the melancholic and choleric. Under the influence of Kraepelin, "manic-depressive insanity" has come to be regarded as an entity in psychiatry; but in so far as this classification assumes that the two moods are fundamentally associated, it would seem to be a departure for the worse from the old ideas of mania, melancholia, and circular insanity.

\section{4. "NORMAL" MOOD.}

"Normal" may be regarded as a state, which is certainly not more common than all the other states, in which the possessor is uniformly cheerful without being boisterous, easy-going, calm, sensible, wellbalanced, and en rapport socially. The possessor works and plays moderately, laughs quietly, does not weep easily, feels little drive, and on the other hand is always responsive and coöperative. 


\section{GENERAL FACTS OF HEREDITY.}

An examination of the family histories of the hyperkinetic and hypokinetic indicates that in some families there is a prevailing tendency for the one condition, in other families for the other, while still other families show the mixed state or a stable mood scattered among the other moods. Examples of these families are given in the pedigree charts. Attention may be drawn to Nos. I, 3, 22, 31, 35, and 45 as examples of prevailing hyperkinesis, and Nos. $25,34,36,52$, and 80 as of mixed or circular types, while $17,55,58,61,65$, and 74 show a large proportion of stable or near-stable individuals.

\section{HYPOTHESIS AS TO HEREDITY.}

How can we bring under one general scheme the inheritance of these various types of mood? After several preliminary trials the following hypothesis was selected for detailed testing:

There is in the germplasm a factor, E, which induces the more or less periodic occurrence of an excited condition (or an exceptionally strong reactibility to exciting presentations) and its absence, $e$, which results in an absence of extreme excitability. There are also the factor $C$, which makes for normal cheerfulness of mood, and its absence, $c$, which permits a more or less periodic depression. Moreover, these factors behave as though in different chromosomes, so that they are inherited independently of each other and may occur in any combination.

What the nature of these factors is, whether they affect primarily the development of certain parts of the nervous system or the secretions of certain glands, is not known and is not involved in the hypothesis. It is even conceivable that each state may be due to more than the pair of factors here suggested; but if the hypothesis fits the facts it would indicate that in the factors $\mathrm{E}$ and $\mathrm{C}$ we have the predominating influences that control mood.

\section{TEST OF THE HYPOTHESIS.}

1. METHOD.

The general method employed in the test of the hypothesis is as follows: From the family histories available for the study of mood, S9 were finally selected as sufficiently full for the purpose. There was no selection of these family histories because it was foreseen that they would supply facts fitting the hypothesis, and 110 rejections of any histories because they afforded statements opposed to the hypothesis. In these 89 family histories were fonnd 146 matings that could be used because the mated pair, their parents (usually), and certain of their offspring were sufficiently described for the purposes of the test.

Let us consider, first, the case where a person of pure, excitable strain $\left(\mathrm{E}_{2}\right)$ marries one of a pure unexcitable strain $\left(\mathrm{e}_{2}\right)$. The ganetes are respectively $\mathrm{E}, \mathrm{E}$, and $\mathrm{e}, \mathrm{e}$, and the zygotes are $\mathrm{E}$ e. 'This is the 
$\mathrm{F}_{1}$ generation. If two persons who are simplex in the excitation factor mate, we have the possible zygotic combinations in generation $F_{2}$ : $\mathrm{E}_{2}, \mathrm{Ee}$, and $\mathrm{e}_{2}$, of which the middle term will be as frequent as the first and last together. Similarly, where a pure cheerful (C) and a depressed (c) strain are mated, in the $\mathrm{F}_{2}$ generation, $\mathrm{C}_{2}, \mathrm{Cc}$, and $\mathrm{c}_{2}$ combinations will be found. If, finally, the mating be made between the Ee hybrids and the $\mathrm{Cc}$ hybrids, we may get in a hybridized population no less than 9 combinations. These are listed in table A, which gives the zygotic formula and with each a coefficient indicating roughly its relative frequency, also a term which indicates the extremes of fluctuations of mood of the person with the zygotic formula. One notes that, in table $\mathrm{A}$, it is assumed that there is typically a difference in the mood of a person with two doses or only one dose of a determiner; that two doses of the $\mathrm{E}$ factor produce the choleric temperament, while only one dose results in the nervous temperament; that two doses of the $\mathrm{C}$ factor result in a normal, cheerful state, while if only one dose is present the individual has a tendency to appear phlegmatic, and if $\mathrm{C}$ is wholly absent, to appear melancholic. This difference in the expression of a trait according as it depends on a duplex or simplex condition of the determiner has been repeatedly noticed and is perhaps the general rule. Yet all students of genetics are aware that in some cases the traits arising from the simplex and the duplex conditions of the determiners are indistinguishable, while in some other cases in the simplex condition the trait may even fail to arise. These experimentally observed facts have to be taken into account in comparing observed behavior with probable zygotic constitution.

TABLE A.-Zygotic formula of descendants of a mixture of excited and depressed strains.

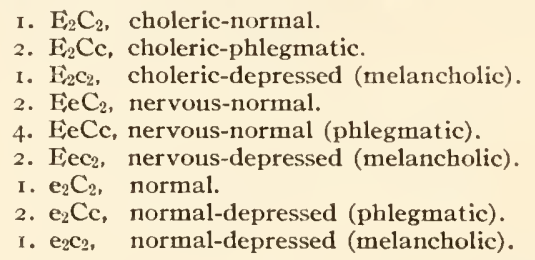

It is assumed, also, that the mixed or alternating states are due to the concurrence of the presence of the excited and the absence of the cheerful factors. It seems probable that, as experience shows, these two states should not occur simultaneously, but should alternate. However, as psychiatrists know, the separation in time of these opposing traits varies greatly, and not a few cases are known where the elated and depressed states seem to appear in an intimate mixture. This mixed condition is fully described, for example, by Stransky (I9I I, pp. 57-65). It appears in transition from the elated to the depressed phase, but also wholly independent of such transition. The mixture may be a very intimate, strictly simultaneous one, $i . e$., at the same 
time manic and depressed components are interwoven, or such connpo nents may follow one after the other in quick succession.

The next step is to see whether, upon applying the 111ost probable zygotic formulæ to various pairs of parents, the distribution of inood as found in the offspring is such as would be called for by the liypothesis. From our family histories I 46 matings were chosen on the basis of such fullness of knowledge that the probable zygotic constitution of parents and offspring could be inferred.

The criteria of suitability of the zygotic formula are these: First, the zygotic formula is ordinarily one that corresponds to a set of characters found in the individual, as summarized in table A. Thus, if the person is liable to periods of marked excitement (without corresponding periods of depression) he is assigned the zygotic formula $\mathrm{E}_{2} \mathrm{C}_{2}$. For example, the formula is applied in mating $\mathrm{s} a$ to a man who is "a great fighter of ugly, disagreeable disposition." In I6, to a man who was of a surly, disagreeable disposition; would beat his children, was hypererotic and brutal to his wife. In mating 3 , to a man who would periodically roar and screain and struggle violently. In mating 8 , to a woman who at 46 years began to have violent spells of laughter and rage and to want to shoot her friends; at the hospital she was disagreeable and profane; discharged at the age of 50 years, she is now disagreeable when crossed and has fits of unreasonable laughter.

When the non-excited state shows certain elements below the normal the formula $\mathrm{E}_{2} \mathrm{Cc}$ is applied. Thus, in mating 2 the mother is subject to attacks of mania, is violent, nomadic, and has hysterical spasms. But she has been, at times, depressed and emotional. The prevailing fabric in her attacks is violent, restless, emotional; but this is mixed with a religious and depressed thread.

When the patient shows at times a clear alternation of elated and depressed states of approximately equal degree, the zygotic formula $\mathrm{E}_{2} \mathrm{c}_{2}$ is applied. Thus, in mating $8 \mathrm{o} b$, the father, in a State hospital, had unsystematized, exalted, morbid ideas; becane homicidal, sleepless, restless; at times dull, confused, resistive; at others, exalted, talkative, silly, and violent. This is a nearly typical picture of the manic-depressive. His daughter, when she "came out" at I9, was the belle of a southern city and for 2 years led a very gay life: was attractive to men and became engaged to two of them; smoked 40 cigarettes a day; took a good deal of champagne and one cocktail after another. At a summer house-party she became suddenly depressed and homesick and returned home, keeping in the house, reading and sewing. until December, occasionally saying she wished slie were dead. Again, after a slight operation, she broke off her engagement and was depressed for a year. The next year at the seashore she becane noisy, screaning, using bad language, and "turkey-trotting" in public places; in the house, tore down curtains, and at the lospital was over-active and 
over-talkative; had a rhyming tendency, a flight of ideas, and a desire to dance.

The normal-depressed condition to which the formula $\mathrm{e}_{2} \mathrm{c}_{2}$ is applied is exemplified in the mother of mating $86 \mathrm{c}$. She is apt to worry and brood, but never to speak of her troubles; she is permanently depressed even when well, and, after the birth of her last child, she began to talk incoherently and to entertain delusions; her mind became confused; she spoke of suicide and asked to be hung. Her mother (mating 86b) was a nervous, quiet woman, who cried easily and worried constantly. At the age of 25 years she had a spell of exceptional depression and acted and talked wildly; she is said to have been poetical.

To the normal individual is assigned the formula $\mathrm{e}_{2} \mathrm{C}_{2}$. This formula is frequently applied to a person of whom we have only the statement that he was normal. It is properly applied to a person who has no extremes of mood. Such, e. g., is the father in mating I 5. For many years he taught school; he has a generous disposition; is religious but not narrow; he liked the country best, but moved to the city for his wife's sake; after her death he returned to the country and engaged in farming. Again, mating 2, the father is a hardworking farmer, eventempered, industrious, temperate, and patient with his wife.

There are, of course, numerous intermediate grades, and to these the various formulæ in table $\mathrm{A}$ are applied, as seem most apt.

But a second criterion has also to be observed. As is well known, persons may carry in their germ-cells determiners for "recessive" traits that they do not show. Hence "ancestry," including collaterals, must be considered to learn the probability that such recessive trait is carried. Since, by hypothesis, the depressed condition is due to the absence of the $\mathrm{C}$ determiner and is thus recessive, likewise since a normal state, e, is recessive to $\mathrm{E}$, such determiners for recessive conditions must be looked for in the family history. If the antecedent family history is sufficiently complete, it may absolutely fix the zygotic composition of the individual in question, and so his gametic composition becomes precisely known. Repeatedly, in our table, we have cases of children to whom a zygotic formula has been applied based on probable parental gametes. These are parents in another mating, where that same zygotic formula has served well to interpret the conditions found in their children. These cases are too numerous to cite. They will be found in most cases where 2 matings in the same family have been included in table $\mathrm{C}$.

Moreover, in assigning a zygotic formula to a parent, especially if the ancestry of the parent is imperfectly known, some account may, occasionally, be taken of the progeny. This is done only with caution, as it tends to test the hypothesis by a bit of circular reasoning; and yet it is justifiable to employ the method to a limited extent where progeny furnish the only clue to gametic composition of the parent. 
The kinds of offspring and the proportions of each that are to be expected from each mating are set forth in table B. 'I'his shows, for example, that when one parent is choleric-cheerful and the other the same, all children will be of this type; but if the other parent is nervousphlegmatic, the children will be of the four classes: choleric-cheerful, choleric-phlegmatic, nervous-cheerful, and nervous-phlegmatic. The greatest variety (including all types) of offspring is derived from the mating of two nervous-phlegmatic parents.

TABLE B.-Most probable distributions of temperaments in the off spring corresponding to each combination of temperamental zygotic make-up of the parents. Assumed number to the fraternity, 8 .

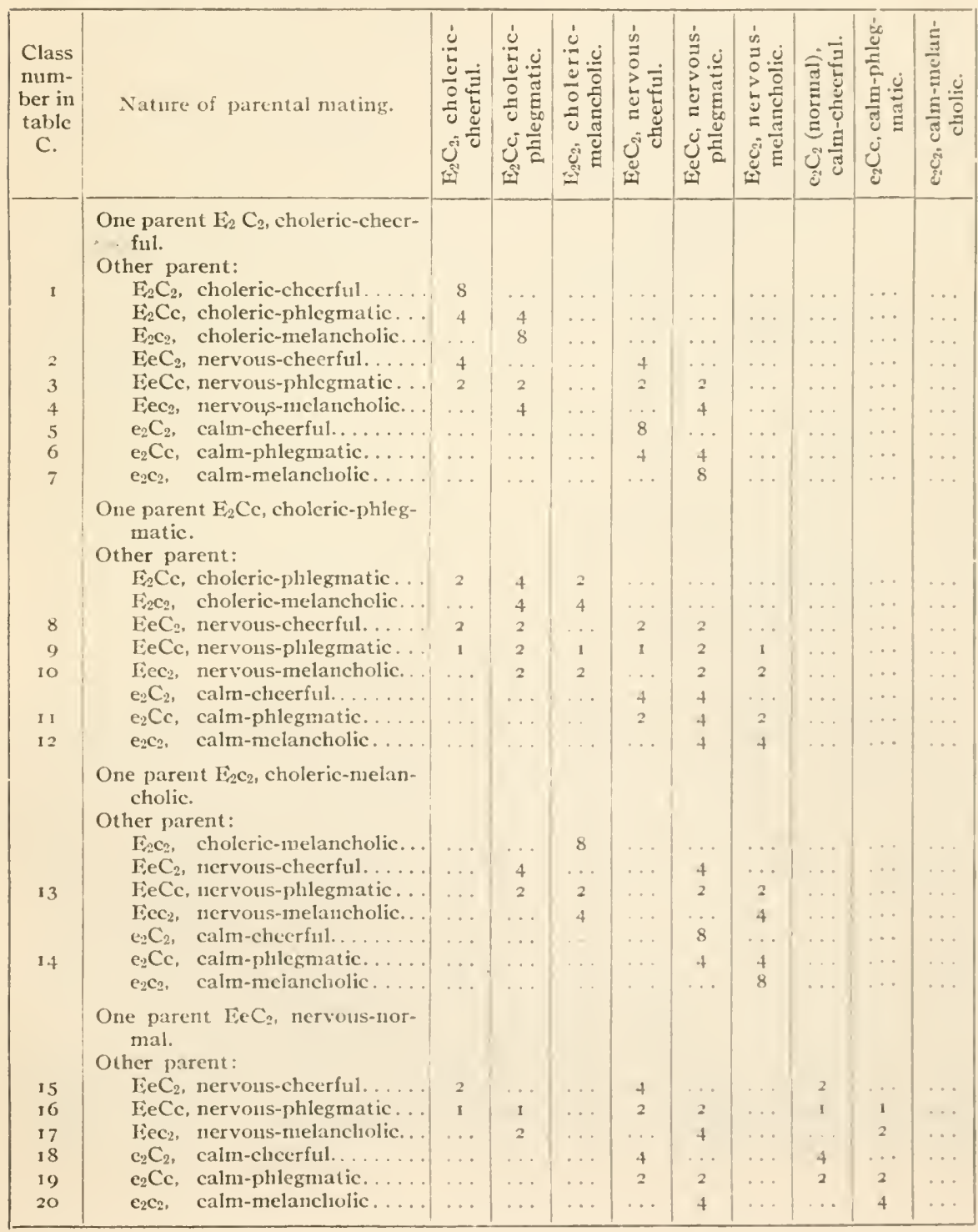


TABLE B.-Most probable distributions of temperaments in the offspring corresponding to each combination of temperamental zygotic make-up of the parents. Assumed number to the fraternity, 8.-Continued.

\begin{tabular}{|c|c|c|c|c|c|c|c|c|c|c|}
\hline $\begin{array}{c}\text { Class } \\
\text { num- } \\
\text { ber in } \\
\text { table } \\
\text { C. }\end{array}$ & Nature of parental mating. & 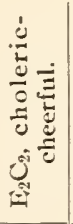 & 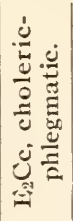 & 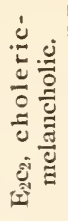 & 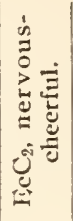 & 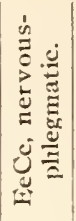 & 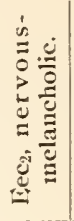 & 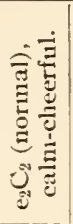 & 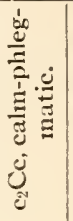 & 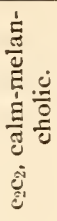 \\
\hline $\begin{array}{l}21 \\
22 \\
23 \\
24 \\
25\end{array}$ & 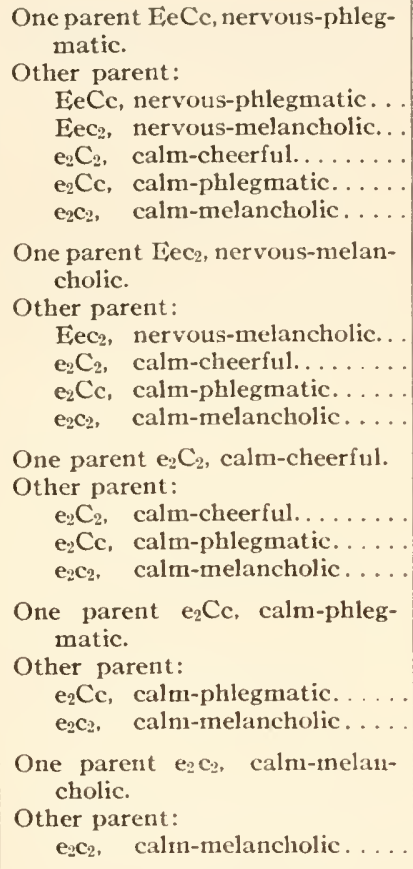 & $\begin{array}{l}\frac{1}{2} \\
\cdots \\
\cdots \\
\cdots \\
\cdots\end{array}$ & $\begin{array}{l}I \\
1 \\
\cdots \\
\cdots \\
\cdots\end{array}$ & $\begin{array}{l}\mathrm{I}^{\frac{1}{2}} \\
\ldots \\
\cdots \\
\cdots\end{array}$ & $\begin{array}{c}\mathrm{I} \\
\ldots \\
2 \\
\mathrm{I} \\
\ldots\end{array}$ & $\begin{array}{l}\cdots \\
\cdots \\
\cdots\end{array}$ & $\begin{array}{l}1 \\
2 \\
\cdots \\
1 \\
2\end{array}$ & $\begin{array}{l}\cdots \\
\cdots \\
\cdots \\
\cdots\end{array}$ & $\begin{array}{l}\ldots \\
4 \\
2 \\
\cdots\end{array}$ & $\begin{array}{l}\frac{1}{2} \\
1 \\
1 \\
2 \\
2\end{array}$ \\
\hline
\end{tabular}

It may be objected that any hypothesis may be proved by the foregoing method, and that any parentage can be made to fit any fraternity of offspring. But this is not true. For example, if either parent is choleric then all of the children will be choleric or nervous. If either parent is steadily "cheerful," then none of the children will be depressed. If both parents are steadily calm then none of the offspring will be choleric or nervous. If both parents are melancholic, then none of the children will be cheerful. Among the 629 progeny the unexpected temperaments do, as a matter of fact, appear only exceptionally. Each exception is referred to in detail. There have, indeed, been not a few cases where additional details were greatly desired. In a few cases it was practicable, by special inquiry, to secure additional data, but the great expense of the special trips required for the purpose limited such inquiries. 
I am quite free to confess that the descriptions afforded were by 110 means always all that could be desired. I will not deny that, in more than one mating, I was somewhat "put to it" to account for the conditions in the progeny, given on the "face of the returns," by the most probable zygotic condition of the parents. This is necessarily so from the nature of the data, which are not quantitative. Indeed, no satisfactory method of measuring emotions has yet been devised. Nevertheless, the difficulties are the exceptions and, on the whole, agreenent of findings with hypothesis was striking.

\section{RESULTS.}

Let us now turn our attention to table C, which constitutes the real test of the hypothesis. This table gives the frequency of each class of temperament in the progeny, corresponding with the different combinations of zygotic constitution of the parents. All the matings in which the parents have the same (probable) zygotic formulæ are grouped together, and these matings are arranged in order, proceeding from the combinations containing the greatest proportion of the $\mathrm{E}$ factor down to the combination containing the greatest proportion of the $c$ factor. Reciprocal matings are bunched together, since careful comparison of matings in which they were separated showed no difference; in other words, there is no evidence of sex-linkage. 'The columns corresponding to the different types of offspring are arranged from left to right, primarily in order of decreasing amount of the E factor and secondarily of increasing amount of the c factor. The assignment of one of the offspring to a particular column is made prinarily on the basis of the description of his behavior and mood recorded by the fieldworker, who, of course, had no idea that the descriptions she secured would be used for any such study as this. It is not to be wondered at, then, that in many cases there is no description of the mood of the individual. Such individuals are marked $X$ in the pedigree charts and are not included in the table. In a number of cases offspring are recorded as "stated to be normal," not having been seen by the recorder. In a few cases such persons are assigned to the column $\mathrm{e}_{2} \mathrm{Cc}$ (or calm-phlegmatic), but, usually, to the column $\mathrm{e}_{2} \mathrm{C}_{2}$, or strictly normal. The justification for this is that, theoretically, a person of zygotic formula $\mathrm{e}_{2} \mathrm{Cc}$ may occasionally behave exactly like a person of zygotic formula $\mathrm{e}_{2} \mathrm{C}_{2}$ and, secondly, that, even though there were a slight departure in behavior from the theoretical normal, this would often be not popularly recognized. For this and other reasons the column of strictly normal $\left(\mathrm{e}_{2} \mathrm{C}_{2}\right)$ offspring contains a disproportionately high number of individuals. Usually the offspring are assigned to just those columns where the account of their behavior indicates they belong, and this results, as the inspection of the separate lines shows, in an occasional appearance of an offspring in a class where it is not 
expected. But this departure is never a large one and may readily be due to an imperfection in the record of the mood, either of one of the parents or of the child in question.

Finally, that all the facts may be available to the most critical reader, enabling him to judge for himself of the value of our comparisons, the legends of the 89 pedigree charts give the essential recorded facts concerning the mood of each of the persons indicated, so far as practicable, in the terms in which they were recorded.

In the table the entries in the "offspring" columns are summed at the bottom, and this column of sums is compared with hypothetical expectation. In general, a fairly close parallelism may be noted between calculated and observed. Where an individual has been placed in a column which should show no member by calculation, the "expectation" entry is a full-faced zero. These conspicuous zeros are a warning of failures of actual to agree precisely with expectation. Though there are several zeros (12), yet they amount to only I.9 per cent of all cases. The best test is afforded by the totals in the summary of table $\mathrm{C}$ that is afforded by table $\mathrm{D}$.

The observed and expected totals in table D run fairly close, except that there is an excess of normals $\left(\mathrm{e}_{2} \mathrm{C}_{2}\right)$ and also of the nervous-cheerful $\left(\mathrm{E}_{2} \mathrm{C}_{2}\right)$. These excesses probably arise from a tendency on the part of members of the family to call normal or only slightly nervous some who are really more disturbed. Also, the excess of manic-depressives $\left(\mathrm{E}_{2} \mathrm{c}_{2}\right)$ is to be attributed to the fact that we started with State hospital inmates and hence have selected many families just because they showed (in abnormal proportions) the manic-depressed conditions. Otherwise a comparison of the observed and expected totals speaks for itself.

TABLE C.-Distribution of progeny' of the varions matings compared with hypothetical expectation.

CLASS I. - $\mathrm{E}_{2} \mathrm{C}_{2} \times \mathrm{E}_{2} \mathrm{C}_{2}$.

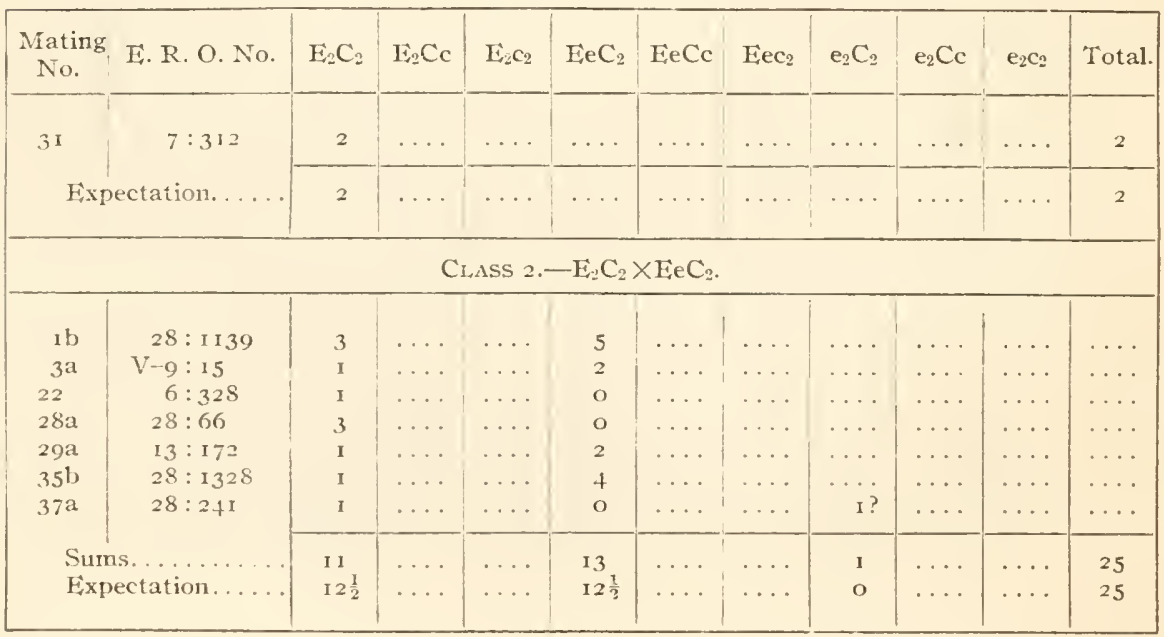


TABLE C.-Distribution of progeny of the various matings compared with hypothetical expectation-Continued.

Cl.Ass 3.- $\mathrm{F}_{2} \mathrm{C}_{2} \times \mathrm{I}$ : CC.

\begin{tabular}{|c|c|c|c|c|c|c|c|c|c|c|c|}
\hline $\begin{array}{c}\text { Mating } \\
\text { No. }\end{array}$ & E. R. O. No. & $\mathrm{E}_{2} \mathrm{C}_{2}$ & $\mathrm{~F}_{2} \mathrm{CC}_{\mathrm{C}}$ & $\mathrm{E}_{2} \mathrm{c}_{2}$ & $\mathrm{EeC}_{2}$ & $\mathrm{IeCc}$ & liec 2 & $\mathrm{e}_{2} \mathrm{C}_{2}$ & $\mathrm{e}_{2} \mathrm{Cc}$ & $e_{2}$ & Total. \\
\hline $82 \mathrm{~b}$ & $28: 1361$ & 2 & I & $\ldots$ & $t$ & $\ldots$ & $\ldots \ldots$ & & & $\ldots$ & + \\
\hline Exp & ectation & I & I & $\ldots$ & $\mathbf{I}$ & 1 & . & & $\ldots$ & & 4 \\
\hline \multicolumn{12}{|c|}{$\mathrm{ClASS}_{4}-\mathrm{Fi}_{2} \mathrm{C}_{2} \times \mathrm{Iiec}_{2}$. } \\
\hline \multirow{2}{*}{$\begin{array}{r}43 a \\
\text { Exp }\end{array}$} & \multirow[t]{2}{*}{$28: 625$} & $\ldots$ & 2 & $\ldots$ & $\ldots$ & & & & . & . . & 2 \\
\hline & & . & 2 & $\ldots$ & . & & & & $\ldots$ & $\ldots$ & 2 \\
\hline
\end{tabular}

Ciass 5.- $\mathrm{F}_{2} \mathrm{C}_{2} \times \mathrm{C}_{2} \mathrm{C}_{2}$.

\begin{tabular}{r|c|c|c|c|c|c|c|c|c|c|c}
\hline $27 \mathrm{C}$ & $21: 404$ \\
Expectation..... & 1 & $\ldots$ & $\ldots$ & $\ldots$ & 1 & $\ldots$ & $\ldots$ & $\ldots$ & $\ldots$ & $\ldots$ & 2 \\
\hline
\end{tabular}

Class 6.- $\mathrm{F}_{2} \mathrm{C}_{2} \times \mathbf{e}_{2} \mathrm{Cc}$.

\begin{tabular}{|c|c|c|c|c|c|c|c|c|c|c|c|}
\hline $1 a$ & $28:$ I 139 & I & $\ldots$ & $\ldots$ & 3 & I & $\ldots$ & .. & $\ldots$ & $\ldots$ & \\
\hline $25 \mathrm{f}$ & $8: 185$ & $\cdots$ & $\ldots$ & $\ldots$ & I & o & $\ldots$ & . & $\ldots$ & .. & \\
\hline $27 \mathrm{~b}$ & $21: 404$ & $\cdots$ & . & & 0 & $\mathrm{t}$ & $\ldots$ & & & $\cdot 1$ & \\
\hline $82 c$ & $28: 1361$ & $\cdots$ & & . & 2 & I & $\ldots$ & 1 & & & \\
\hline \multirow{2}{*}{\multicolumn{2}{|c|}{$\begin{array}{l}\text { Sums. } \\
\text { Expect }\end{array}$}} & $t$ & & . & 6 & 3 & $\ldots$ & I & . & $\ldots$ & it \\
\hline & & o & & & $5 !$ & $5 \frac{1}{2}$ & . . & 0 & & & II \\
\hline
\end{tabular}

$\mathrm{Cl}$..1Ss $7 .-\mathrm{E}_{2} \mathrm{C}_{2} \times \mathrm{e}_{2} \mathrm{C}_{2}$.

$53 a \quad 43: 159$

Expectation

\begin{tabular}{|c|c|c|c|c|c|c|c|c|c|c|}
\hline \multicolumn{11}{|c|}{$\mathrm{Cl}_{\text {LASS }} 8-\mathrm{E}_{2} \mathrm{Cc} \times \mathrm{EcC}_{2}$. } \\
\hline i $7 a$ & $10: 353$ & $\ldots$ & $\ldots$ & I & 1 & $\ldots$ & $\ldots$ & $\ldots$ & $\ldots$ & $=$ \\
\hline \multicolumn{2}{|c|}{ Expectation..... } & $\frac{1}{2}$ & $\frac{1}{2}$ & $\frac{1}{2}$ & $\frac{1}{2}$ & $\ldots$ & $\ldots$ & $\ldots$ & $\ldots$ & 2 \\
\hline
\end{tabular}

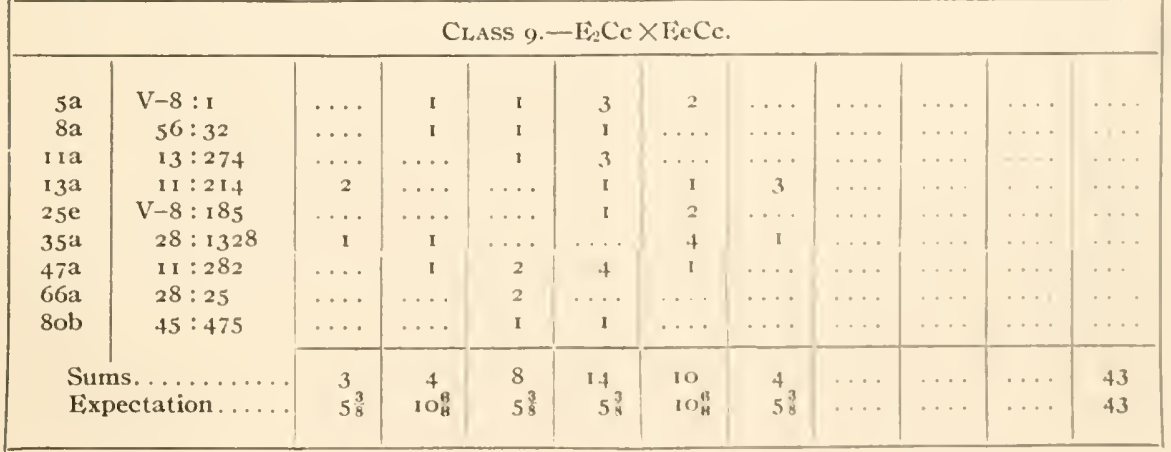


TABLE C.-Distribution of progeny of the earious matings compared "ith hypotheticul expectation-Continued.

Class 10.- $\mathrm{E}_{2} \mathrm{Ci} \times \mathrm{E}_{\mathrm{ec}}$.

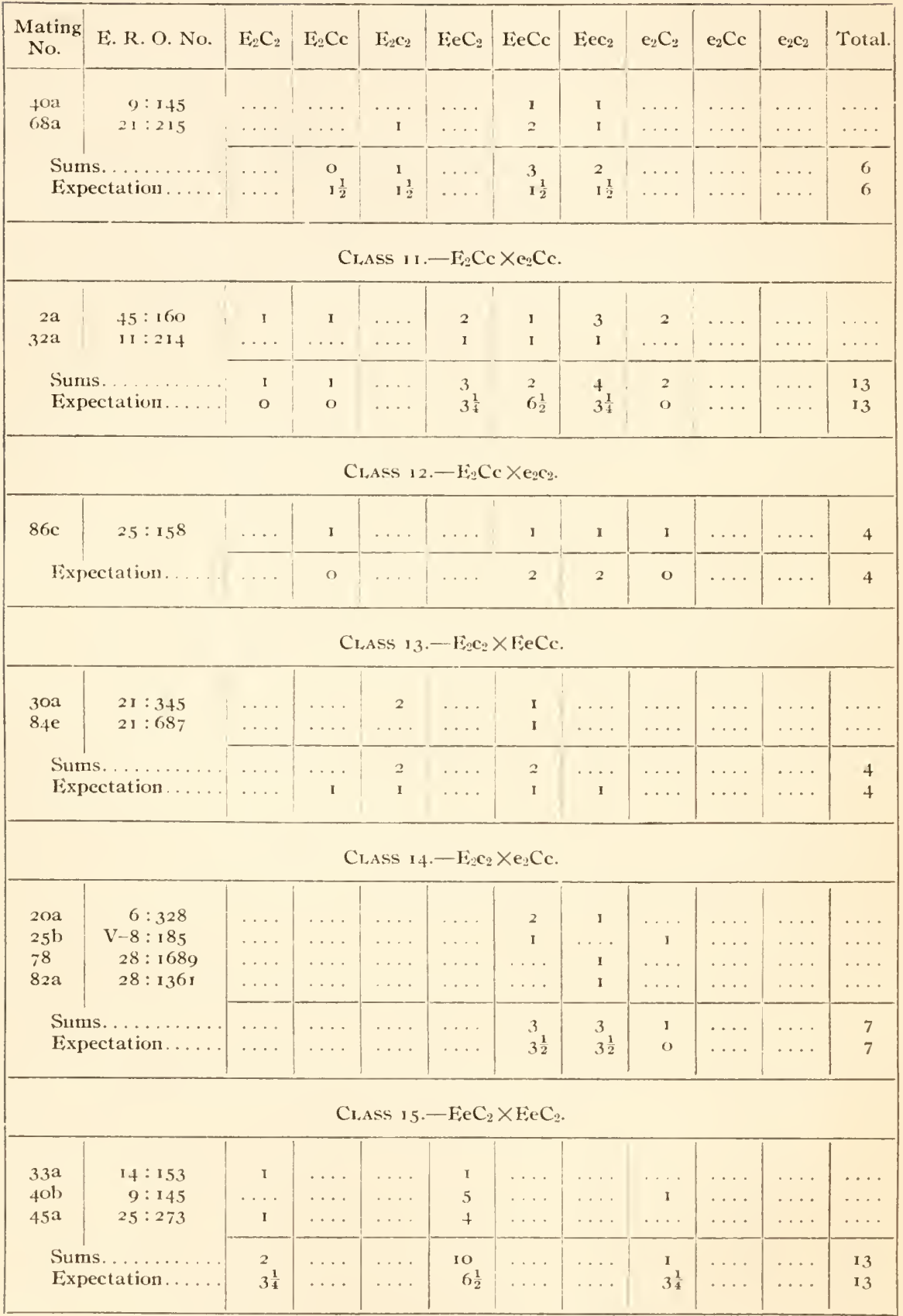


TABLE C.-Distribution of progeny of the a arious malings compared with hypolhelical expeclation-Continued.

Chass 16. $-\mathrm{EeC}_{2} \times$ I:eCc.

\begin{tabular}{|c|c|c|c|c|c|c|c|c|c|c|c|}
\hline $\begin{array}{c}\text { Mating } \\
\text { No. }\end{array}$ & E. R. O. No. & $\mathrm{E}_{2} \mathrm{C}_{2}$ & $\mathrm{E}_{2} \mathrm{Cc}$ & $\mathrm{r}_{2} \mathrm{c}_{2}$ & $1: \mathrm{eC}_{2}$ & $\mathrm{FeCc}$ & $\mathbf{E e c}_{2}$ & $\mathrm{e}_{2} \mathrm{C}_{2}$ & $\mathrm{e}_{2} \mathrm{Cc}$ & $\mathrm{C}_{2} \mathrm{C}_{2}$ & Total. \\
\hline $9 b$ & $21: 118$ & I & $\ldots$ & $\cdots$ & $\cdots$ & I & $\ldots$ & . & & 1 & \\
\hline $12 a$ & $28: 1740$ & 2 & $\ldots$ & $\ldots$ & 4 & 1 & $\ldots$ & +1 & in & 1. & 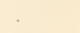 \\
\hline I3d & $41: 25$ & 2 & $\ldots$ & $\ldots$ & 2 & $\ldots$ & $\ldots$. & $\ldots$ & . & & 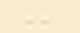 \\
\hline I $6 a$ & $21: 594$ & $\ldots$ & I & $\ldots$ & 3 & 2 & $\ldots$ & 2 & 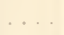 & . . . & \\
\hline $18 \mathrm{a}$ & $45: 76$ & 2 & 1 & $\ldots$ & 2 & $\ldots$ & $\ldots$ & $\ldots$ & & & \\
\hline $24 c$ & Smi. & $\ldots$ & $\ldots$ & $\ldots$ & 2 & $\ldots$ & $\ldots$ & $\ldots$ & - & $\ldots$ & \\
\hline $25 c$ & $V-8: 185$ & $\ldots$ & $\ldots$ & $\ldots$ & 4 & $\ldots$ & $\ldots$ & 2 & 1 & $\ldots$ & 1 \\
\hline $27 a$ & $21: 404$ & I & $\ldots$ & $\ldots$ & I & $\ldots$ & $\ldots$ & $\ldots$ & 3 & $\ldots$ & . \\
\hline $42 a$ & $5: 127$ & $\ldots$ & $\ldots$ & $\cdots$ & 2 & 2 & $\ldots$ & 2 & $\ldots$ & $\cdots$ & $\ldots$. \\
\hline $42 \mathrm{~b}$ & $5: 127$ & $\ldots$ & $\ldots$ & $\ldots$ & 2 & 3 & $\ldots$ & 2 & I & $\ldots$ & . \\
\hline $46 a$ & $25: 189$ & 2 & $\ldots$ & $\ldots$ & 2 & $\ldots$ & $\ldots$ & 4 & I & $\ldots$ & \\
\hline $80 a$ & $40: 475$ & $\cdots$ & 3 & $\ldots$ & 3 & $\cdots$ & $\cdots$ & 2 & . & $\cdots$ & . \\
\hline \multirow{2}{*}{\multicolumn{2}{|c|}{$\begin{array}{l}\text { Sums. } \\
\text { Expect }\end{array}$}} & 10 & 5 & $\cdots$ & 27 & 9 & $\cdots$ & 18 & 6 & $\cdots$ & 7.5 \\
\hline & & 08 & $0 \frac{3}{4}$ & & 184 & $188_{4}^{3}$ & $\cdots$ & $0:$ & 98 & $\cdots$ & 75 \\
\hline
\end{tabular}

C1.ASS 17.- $-\mathrm{EeC}_{2} \times \mathrm{Eiec}_{2}$

\begin{tabular}{|c|c|c|c|c|c|c|c|c|c|c|c|}
\hline $7 \mathrm{c}$ & $22: 252$ & $\ldots$ & I & $\ldots$ & $\ldots$ & $\ldots$ & $\ldots$ & $\ldots$ & 1 & $\ldots$ & $\cdots$ \\
\hline $23 a$ & $14: 173$ & $\ldots$ & $\ldots$ & $\ldots \ldots$ & $\ldots$ & 3 & $\ldots$ & $\ldots$ & I & $\ldots$ & \\
\hline $32 \mathrm{~b}$ & $11: 214$ & $\ldots$ & I & $\ldots$ & $\ldots$ & $\ldots$ & $\ldots$ & $\ldots$ & $\ldots \ldots$ & $\ldots$ & . \\
\hline $60 a$ & $41: 59$ & $\ldots$ & 1 & $\ldots$ & $\ldots$ & $\ldots$ & $\ldots$ & $\ldots \ldots$ & $\ldots$ & $\ldots$ & - \\
\hline \multirow{2}{*}{\multicolumn{2}{|c|}{$\begin{array}{l}\text { Sums....... } \\
\text { Expectition }\end{array}$}} & $\ldots$. & 3 & $\ldots$ & $\ldots$ & 3 & $\ldots$ & $\ldots$ & 2 & $\ldots$ & 8 \\
\hline & tation. & $\ldots$ & 2 & $\ldots$ & . & 4 & $\ldots$ & $\ldots$ & 2 & $\ldots$ & 8 \\
\hline
\end{tabular}

Cr.ASS 18. $-\mathrm{FeC}_{2} \times \mathrm{e}_{2} \mathrm{C}_{2}$.

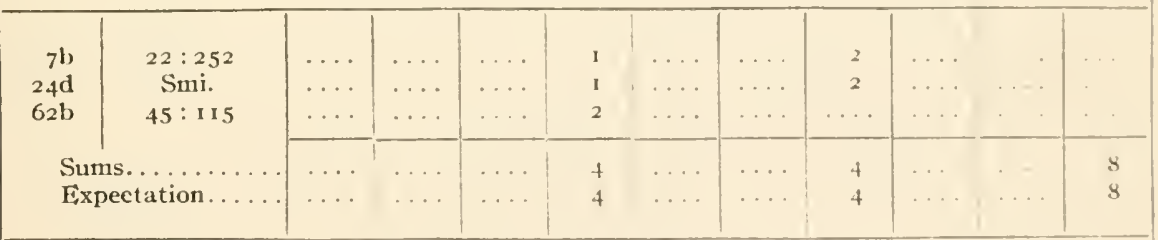

Crass 19.- $\mathrm{IeC}_{2} \times \mathrm{e}_{2} \mathrm{Ce}$.

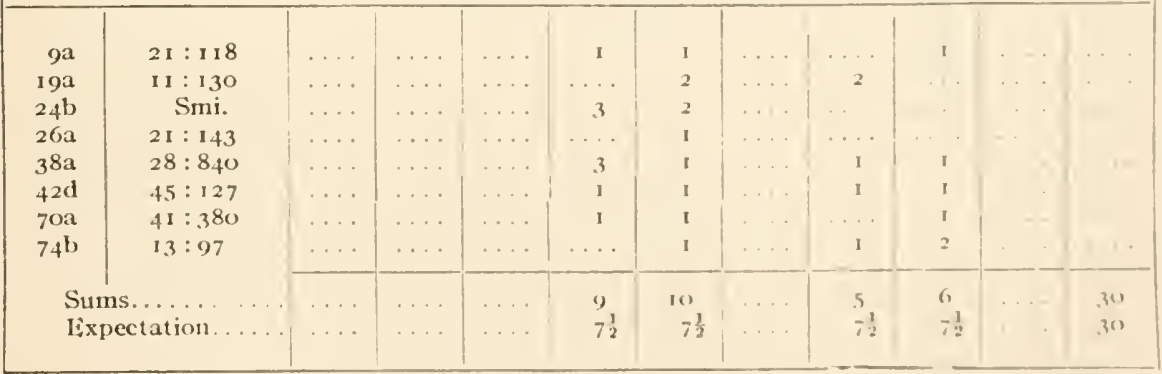


TABLE C.-Distribution of progeny of the various matings compared with hypothetical expectation-Continued.

Class 20.- $-\mathrm{EeC}_{2} \times \mathrm{e}_{2} \mathrm{C}_{2}$.

\begin{tabular}{|c|c|c|c|c|c|c|c|c|c|c|c|}
\hline $\begin{array}{l}\text { Mating } \\
\text { No. }\end{array}$ & E. R. O. No. & $\mathrm{E}_{2} \mathrm{C}_{2}$ & $\mathrm{E}_{2} \mathrm{Cc}$ & $\mathrm{E}_{2} \mathrm{C}_{2}$ & $\mathrm{EeC}_{2}$ & $\mathrm{EeCc}$ & $\mathrm{Eec}_{2}$ & $\mathrm{e}_{2} \mathrm{C}_{2}$ & $\mathrm{e}_{2} \mathrm{Cc}$ & $e_{2} c_{2}$ & Total. \\
\hline $58 \mathrm{a}$ & $7: x 53$ & $\cdots$ & $\ldots$ & $\ldots$ & $\ldots$ & I & . & $\cdots$ & I & $\cdots$ & $\ldots$ \\
\hline $87 a$ & I I : I 89 & $\ldots$ & $\ldots$ & $\ldots$ & . & $\ldots$ & $\cdots$ & $\cdots$ & 3 & $\cdots$ & $\cdots$ \\
\hline \multirow{2}{*}{\multicolumn{2}{|c|}{$\begin{array}{l}\text { Sums . . . . . . . . . } \\
\text { Expectation.... }\end{array}$}} & $\cdots$ & $\ldots$ & $\ldots$ & & I & . & . & 4 & $\cdots$ & 5 \\
\hline & & $\cdots$ & $\ldots$ & & & $2 \frac{1}{2}$ & . & & $2 \frac{1}{2}$ & $\ldots$ & 5 \\
\hline
\end{tabular}

\begin{tabular}{|c|c|c|c|c|c|c|c|c|c|c|c|}
\hline \multicolumn{12}{|c|}{ Class 2 1. - FeCc $\times$ FeCc. } \\
\hline $4^{a}$ & $45:$ I 98 & $\ldots$ & $\ldots$ & 1 & 5 & 3 & 1 & $\ldots$ & 2 & $\ldots$ & $\ldots$ \\
\hline $7 a$ & $25: 252$ & $\ldots$ & I & $\ldots$ & 1 & $\ldots$ & 3 & $\ldots$ & 3 & $\ldots$ & $\ldots$ \\
\hline 2 I & $40: 795$ & $\ldots$ & $\ldots$ & I & 1 & 2 & $\ldots$ & 2 & $\cdots$ & $\ldots$ & $\ldots$ \\
\hline $25 a$ & $V-8: 185$ & $\ldots$ & 2 & $\mathbf{I}$ & $\ldots$ & 1 & $\ldots$ & $\ldots$ & 3 & $\ldots$ & $\ldots$ \\
\hline $26 b$ & $21: 143$ & I & $\ldots$ & $\ldots$ & $\ldots$ & $\ldots$ & I & $\ldots$ & $\cdots$ & $\ldots$ & $\ldots$ \\
\hline $34^{a}$ & $28: 293$ & $\cdots$ & $\ldots$ & $\ldots$ & $\ldots$ & 3 & I & 2 & $\cdots$ & $\cdots$ & $\ldots$ \\
\hline $34 \mathrm{~b}$ & $28: 293$ & $\ldots$ & $\ldots$ & 3 & $\ldots$ & 4 & $\ldots$ & 3 & $\ldots$ & $\ldots$ & $\ldots$ \\
\hline $36 a$ & $28: 1604$ & $\ldots$ & I & $\ldots$ & I & $\ldots$ & I & $\ldots$ & I & $\ldots$ & $\ldots$ \\
\hline $4 \mathrm{Ib}$ & $28:$ I 509 & $\ldots$ & I & $\ldots$ & $\mathbf{I}$ & I & $\ldots$ & I & I & $\ldots$ & $\ldots$ \\
\hline $42 c$ & $45: 127$ & $\ldots$ & $\ldots$ & I & $\ldots$ & 2 & $\ldots$ & $\ldots$ & $\ldots$ & $\ldots$ & $\ldots$ \\
\hline $46 b$ & $25: 189$ & $\ldots$ & $\ldots$ & $I$ & $\ldots$ & $\ldots$ & $\ldots$ & $\ldots$ & $\ldots$ & $\ldots$ & $\ldots$ \\
\hline $49 a$ & I $2: 228$ & $\ldots$ & $\ldots$ & $\ldots$ & $\ldots$ & $\ldots$ & $\ldots$ & $\ldots$ & I & 3 & $\ldots$ \\
\hline $58 \mathrm{~b}$ & $7: 153$ & $\ldots$ & I & $\ldots$ & 3 & I & $\ldots$ & I & 1 & $\ldots$ & $\ldots$ \\
\hline $74 c$ & $13: 97$ & $\ldots$ & $\ldots$ & $\ldots$ & $\ldots$ & $\ldots$ & I & $\ldots$ & $\ldots$ & $\ldots$ & $\ldots$ \\
\hline $76 a$ & $9: 257$ & $\ldots$ & $\cdots$ & $\ldots$ & I & $\ldots$ & I & $\ldots$ & $\ldots$ & I & $\ldots$ \\
\hline $79 a$ & $44: 475$ & $\ldots$ & $\ldots$ & 2 & $\ldots$ & $I$ & $\mathbf{I}$ & 2 & $\cdots$ & $\cdots$ & $\ldots$ \\
\hline $83 a$ & $34: 77$ & $\ldots$ & $\ldots$ & $\ldots$ & $\ldots$ & $\ldots$ & $\ldots$ & $\ldots$ & 3 & $\mathbf{I}$ & $\ldots$ \\
\hline $84 d$ & $21: 687$ & $\ldots$ & $\ldots$ & $\ldots$ & 2 & $\ldots$ & $\ldots$ & $\ldots$ & 2 & $\mathbf{I}$ & $\ldots$ \\
\hline $85 b$ & $4 I: 32 I$ & $\ldots$ & $\ldots$ & $\ldots$ & $\ldots$ & $\ldots$ & $\ldots$ & $\cdots$ & $\ldots$ & $\mathbf{I}$ & $\ldots$ \\
\hline $86 d$ & $25: 158$ & $\ldots$ & $\ldots$ & $\ldots$ & $\ldots$ & $\ldots$ & I & $\ldots$ & $\ldots$ & $\ldots$ & $\ldots$ \\
\hline $86 f$ & $25: 158$ & $\ldots$ & $\ldots$ & $\ldots$ & 2 & $\ldots$ & 1 & 2 & $\ldots$ & $\ldots$ & $\ldots$ \\
\hline $89 a$ & $9: 78$ & $\ldots$ & $\ldots$ & I & $\ldots$ & 2 & $\ldots$ & $\ldots$ & $\ldots$ & $\cdots$ & $\ldots$ \\
\hline \multirow{2}{*}{\multicolumn{2}{|c|}{$\begin{array}{l}\text { Sums... . . . . . . . } \\
\text { Expectation. . . . }\end{array}$}} & I & 6 & I I & 17 & 20 & 12 & 13 & 17 & 7 & 104 \\
\hline & & $6 \frac{1}{2}$ & 13 & $6 \frac{1}{2}$ & I 3 & 26 & 13 & $6 \frac{1}{2}$ & 13 & $6 \frac{1}{2}$ & 104 \\
\hline
\end{tabular}

\begin{tabular}{|c|c|c|c|c|c|c|c|c|c|c|c|}
\hline \multicolumn{12}{|c|}{ Ci.ass 22. $-\mathrm{EeCc} \times \mathrm{Fec}_{2}}$. \\
\hline $5 b$ & $V-8: \mathbf{I}$ & $\ldots$ & $\ldots$ & $\ldots$ & $\ldots$ & 3 & I & ..... & . . . & 2 & . \\
\hline $6 a$ & $V-8: 93$ & $\ldots$ & I & $\ldots$ & $\cdots$ & 1 & I & $\cdots$ & I & I & $\cdots$ \\
\hline $39 a$ & $28: 984$ & $\ldots$ & $\ldots$ & $\ldots$ & $\ldots$ & $\ldots$ & 2 & $\ldots$ & I & 5 & $\ldots$ \\
\hline $68 \mathrm{~b}$ & $21: 2$ I5 & $\ldots$ & $\ldots$ & I & $\ldots$ & 2 & I & $\ldots$ & $\ldots$ & $\ldots$ & $\ldots$ \\
\hline $71 a$ & $44: 435$ & $\ldots$ & $\ldots$ & 2 & $\ldots$ & 2 & 2 & $\ldots$ & $\ldots$ & $\ldots$ & $\ldots$ \\
\hline $7 \mathrm{Ib}$ & $44: 435$ & $\ldots$ & $\ldots$ & I & $\ldots$ & I & $\ldots$ & $\ldots$ & I & $\ldots$ & ... \\
\hline $73 a$ & $56: 40$ & $\ldots$ & 1 & 2 & $\ldots$ & $\ldots$ & $\ldots$ & $\ldots$ & $\ldots$ & $\ldots$ & $\ldots$ \\
\hline $84 \mathrm{~b}$ & $21: 687$ & $\ldots$ & $\ldots$ & I & $\ldots$ & I & $\ldots$ & $\ldots$ & I & $\ldots$ & $\ldots$ \\
\hline \multirow{2}{*}{\multicolumn{2}{|c|}{$\begin{array}{l}\text { Sums........... } \\
\text { Expectation...... }\end{array}$}} & $\ldots$ & & 7 & $\ldots$ & IO & 7 & $\ldots$ & + & 8 & 38 \\
\hline & & $\ldots$ & $4 \frac{3}{4}$ & $4^{\frac{3}{4}}$ & $\ldots$ & $9^{\frac{1}{2}}$ & $9 \frac{1}{2}$ & $\cdots$ & $4 \frac{3}{4}$ & $4 \frac{3}{4}$ & 38 \\
\hline \multicolumn{12}{|c|}{$\mathrm{Cl}_{\text {ASS }} 23 .-\mathrm{E} \mathrm{eCc} \times \mathrm{e}_{2} \mathrm{C}_{2}$. } \\
\hline $15 \mathrm{a}$ & $40: 741$ & $\ldots$ & $\ldots$ & $\ldots$ & $\ldots$ & 2 & $\ldots$ & 3 & $\ldots$ & $\ldots$ & $\ldots$ \\
\hline $24 a$ & Smi. & $\ldots$ & $\ldots$ & $\ldots$ & 2 & I & $\ldots$ & I & I & $\ldots$ & $\ldots$ \\
\hline $86 \mathrm{e}$ & $25: \mathbf{I} 58$ & $\ldots$ & $\cdots$ & $\cdots$ & $\ldots$ & $\mathbf{I}$ & $\cdots$ & 3 & $\cdots$ & $\cdots$ & $\cdots \cdots$ \\
\hline \multirow{2}{*}{\multicolumn{2}{|c|}{$\begin{array}{l}\text { Sums............ } \\
\text { Expectation... . . }\end{array}$}} & $\ldots$ & $\ldots$ & $\ldots$ & 2 & 4 & $\ldots$ & 7 & $\mathbf{I}$ & $\ldots$ & 14 \\
\hline & & $\ldots$ & & $\ldots$ & $3 \frac{1}{2}$ & $3 \frac{1}{2}$ & $\ldots$ & $3 \frac{1}{2}$ & $3 \frac{1}{2}$ & $\ldots$ & 14 \\
\hline
\end{tabular}


TABLE C.-Distribution of progeny of the various malings compared with hypothetical expectation-Continued.

$\mathrm{Cl}$.ASS 24.- $\mathrm{HeCe} \times \mathrm{e}_{2} \mathrm{Cc}$.

\begin{tabular}{|c|c|c|c|c|c|c|c|c|c|c|c|}
\hline $\begin{array}{c}\text { Mating } \\
\text { No. }\end{array}$ & E. R. O. No. & $\mathrm{I}_{2} \mathrm{C}_{2}$ & $\mathrm{I}_{2} \mathrm{Cc}$ & $\mathrm{E}_{2} \mathrm{C}_{2}$ & $\mathrm{EeC}_{2}$ & Eecc & $\mathrm{Iec}_{2}$ & $\mathrm{e}_{2} \mathrm{C}_{2}$ & $\mathrm{e}_{2} \mathrm{Cc}$ & ex: & rotal. \\
\hline $25 d$ & $8: 185$ & $\ldots$ & $\ldots$ & $\ldots$ & $\ldots$ & 3 & $\ldots$ & I & $\ldots$ & $\ldots$ & \\
\hline $41 a$ & $28: 1509$ & $\ldots$ & $\ldots$ & $\ldots$ & 1 & I & $\ldots$ & $\ldots$ & $\ldots$ & 2 & $\ldots$ \\
\hline $48 a$ & $11: 148$ & $\ldots$ & $\ldots$ & $\cdots$ & 2 & $\ldots$ & $\ldots$ & $\ldots$ & $\ldots$ & I & $\ldots$ \\
\hline $50 a$ & $28: 933$ & $\ldots$ & $\ldots$ & $\ldots$ & $\ldots$ & 2 & 2 & 3 & 2 & $\ldots$. & $\ldots \ldots$ \\
\hline $52 a$ & $40: 764$ & $\ldots$ & $\ldots$ & $\ldots$ & + & 1 & I & $\ldots$ & $\ldots$ & $\ldots$. & $\ldots \ldots$ \\
\hline $56 a$ & $13: 39$ & $\ldots$ & $\ldots$ & $\ldots$ & 2 & I & $\ldots$ & $\ldots$ & 4 & 2 & $\ldots$. \\
\hline $57 \mathrm{a}$ & $22: 42$ & $\ldots$ & $\ldots$ & $\ldots$ & $\ldots$ & 4 & 2 & $\ldots$ & $\ldots$ & $\ldots$. & $\ldots$. \\
\hline $57 \mathrm{~b}$ & $22: 42$ & $\ldots$ & $\ldots$ & $\ldots$ & $\ldots$ & 2 & I & I & 1 & $\ldots$ & $\ldots$ \\
\hline $59 a$ & $40: 5$ I 4 & $\ldots$ & $\ldots$ & $\ldots$ & I & 2 & $\ldots$ & 1 & $\ldots$ & $\ldots$ & $\ldots$ \\
\hline $59 \mathrm{~b}$ & $40: 514$ & $\ldots$ & $\ldots$ & $\ldots$ & $\mathbf{I}$ & I & $\ldots$ & $\ldots$ & 2 & 4 & $\ldots$ \\
\hline $61 a$ & $41: 373$ & $\ldots$ & $\ldots$ & $\ldots$ & $\ldots$ & $\ldots$ & 1 & 1 & $\ldots$ & $\ldots$ & $\ldots$ \\
\hline $63 a$ & $12: 113$ & $\ldots$ & $\ldots$ & $\ldots$ & $\ldots$ & I & $\ldots$ & 1 & I & 1 & $\ldots$ \\
\hline $64 c$ & $22: 74 \ldots \ldots$ & $\ldots$ & $\ldots$ & $\ldots$ & $\ldots$ & 1 & $\ldots$ & $\ldots$ & 1 & 1 & $\ldots$ \\
\hline $65 a$ & $45: 210$ & $\ldots$ & $\ldots$ & $\ldots$ & $\ldots$ & 1 & $\ldots$. & $\ldots$ & $\ldots$ & $\ldots$ & $\ldots$. \\
\hline $65 \mathrm{~b}$ & $45: 210$ & $\ldots$ & $\ldots$ & $\ldots$ & $\ldots$ & 3 & 2 & 2 & 2 & 1 & $\ldots$ \\
\hline $72 b$ & $22: 118$ & $\ldots$ & $\ldots$ & $\ldots$ & $\ldots$ & I & $\ldots$. & $\ldots$ & 2 & $\ldots$ & $\ldots$ \\
\hline $75 a$ & $44: 288$ & $\ldots$ & $\ldots$ & $\ldots$ & 1 & $\ldots$ & I & $\ldots$ & $\ldots$ & $\ldots$ & $\ldots$ \\
\hline $81 a$ & $21: 314$ & $\ldots$ & $\ldots$ & $\ldots$ & I & 1 & $\ldots$ & $\ldots$ & $\ldots$ & 1 & $\ldots$ \\
\hline $85 a$ & $41: 321$ & $\ldots$ & $\ldots$ & $\ldots$ & 3 & 2 & $\ldots$ & I & $\ldots$ & 1 & $\ldots \ldots$ \\
\hline $86 a$ & $25: 158$ & $\ldots$ & $\ldots$ & $\ldots$ & I & 1 & $\ldots$ & 3 & I & $\mathbf{I}$ & $\ldots$ \\
\hline \multirow{2}{*}{\multicolumn{2}{|c|}{$\begin{array}{l}\text { Sums....... } \\
\text { Expectation }\end{array}$}} & $\ldots$ & $\ldots$ & $\ldots$ & 17 & 28 & 10 & 14. & 16 & I 5 & 100 \\
\hline & & $\ldots$ & $\ldots$ & $\ldots$ & $12 \frac{1}{2}$ & 25 & $12 \frac{1}{2}$ & $12 \frac{1}{2}$ & 25 & $12 \frac{1}{2}$ & 100 \\
\hline
\end{tabular}

\begin{tabular}{|c|c|c|c|c|c|c|c|c|c|c|c|}
\hline \multicolumn{12}{|c|}{$\mathrm{Cr}_{1} \mathrm{ASS} 25 .-\mathrm{FeCc} \times \mathrm{e}_{2} \mathrm{C}_{2}$. } \\
\hline $6_{3} b$ & $12: 113$ & $\ldots$ & $\ldots$ & $\ldots$ & $\ldots$ & I & 2 & $\ldots$ & 2 & 3 & $\ldots$ \\
\hline $64 a$ & $22: 74$ & $\ldots$ & $\ldots$ & $\ldots$ & $\ldots$ & 2 & $\ldots$ & $\ldots$ & 1 & 1 & $\ldots \ldots$ \\
\hline $64 \mathrm{~b}$ & $22: 74$ & $\ldots$ & $\ldots$ & $\ldots$ & $\ldots$ & 1 & $\ldots$ & $\ldots$ & 3 & $\ldots$ & $\ldots$ \\
\hline $67 a$ & $28: 20$ & $\ldots$ & $\ldots$ & $\ldots$ & $\ldots$ & 2 & $\ldots$ & $\ldots$ & I & 2 & $\ldots$ \\
\hline 69 & $23: 262$ & $\ldots$ & $\ldots$ & $\ldots$ & $\ldots$ & 1 & I & $\ldots$ & $\ldots$ & 2 & $\ldots$ \\
\hline $7 \mathrm{ob}$ & $41: 380$ & $\ldots$ & $\ldots$ & $\ldots$ & $\ldots$ & $\ldots$ & I & $\ldots$ & I & $\ldots$ & $\ldots$ \\
\hline $84 c$ & $21: 687$ & $\ldots$ & $\ldots$ & $\ldots$ & $\ldots$ & $\ldots$ & I & $\ldots$ & $\ldots$ & $\ldots$ & $\ldots$ \\
\hline $86 b$ & $25: 1.58$ & $\ldots$ & $\ldots$ & $\ldots$ & $\ldots$ & 6 & $\ldots$ & $\ldots$ & 1 & 1 & $\cdots$ \\
\hline \multicolumn{2}{|c|}{ Sums......... } & $\ldots$ & $\ldots$ & $\ldots$ & $\ldots$ & 13 & 5 & $\ldots$ & 9 & 9 & 36 \\
\hline \multicolumn{2}{|c|}{ Expectation... } & $\ldots$. & $\ldots$ & $\ldots$ & $\ldots$ & 9 & 9 & $\ldots$ & 9 & 9 & 36 \\
\hline
\end{tabular}

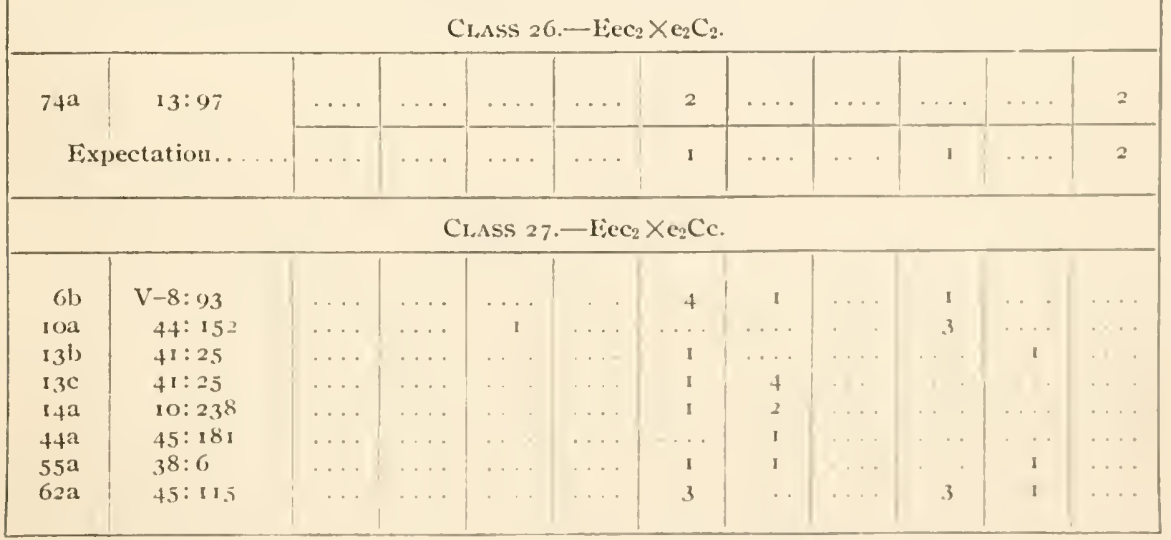


TABLE C.-Distribution of progeny of the varions matings compared with hypothetical expectation-Continued.

$\mathrm{Cl}_{1}, \mathrm{SSS} 27 .-\mathrm{Lec}_{2} \times \mathrm{e}_{2} \mathrm{Cc}$-continued.

\begin{tabular}{|c|c|c|c|c|c|c|c|c|c|c|c|}
\hline $\begin{array}{c}\text { Mating } \\
\text { No. }\end{array}$ & E. R. O. No. & $\mathrm{E}_{2} \mathrm{C}_{2}$ & $\mathrm{E}_{2} \mathrm{Cc}$ & $\mathrm{E}_{2} \mathrm{c}_{2}$ & $\mathrm{E}_{\mathrm{eC}}$ & $\mathrm{EeCe}$ & $\mathrm{Eec}_{2}$ & $\mathrm{e}_{2} \mathrm{C}_{2}$ & $\mathrm{e}_{2} \mathrm{Cc}$ & $\mathbf{e}_{2} \mathrm{c}_{2}$ & Total \\
\hline $72 a$ & $22: 118$ & $\ldots$ & $\ldots$ & $\cdots$ & $\ldots$ & I & 2 & $\ldots$ & I & $\ldots$ & $\ldots$ \\
\hline $77 \mathrm{a}$ & $34: 161$ & $\ldots$ & $\cdots$ & $\ldots$ & $\ldots$ & I & 3 & $\ldots$ & I & $\ldots$ & $\ldots$ \\
\hline $84 a$ & $21: 687$ & $\ldots$ & $\ldots$ & $\ldots$ & $\ldots$ & 5 & I & $\ldots$ & $\ldots$ & $\ldots$ & $\ldots$ \\
\hline $88 a$ & $44: 316$ & $\ldots$ & $\ldots$ & $\ldots$ & $\ldots$ & I & I & $\ldots$ & I & $\ldots$ & $\ldots$ \\
\hline \multicolumn{2}{|c|}{ Sums....... } & $\begin{array}{l}\ldots \\
\ldots\end{array}$ & $\ldots$ & $\begin{array}{l}\text { I } \\
\text { o }\end{array}$ & $\ldots$ & $\begin{array}{l}19 \\
12 \frac{1}{4}\end{array}$ & $\begin{array}{l}16 \\
12 \frac{1}{4}\end{array}$ & $\ldots$ & $\begin{array}{l}10 \\
12 \frac{1}{4}\end{array}$ & $\begin{array}{c}3 \\
12 \frac{1}{4}\end{array}$ & $\begin{array}{l}49 \\
49\end{array}$ \\
\hline \multicolumn{12}{|c|}{$\mathrm{CLASS}_{\text {28. }}-\mathrm{e}_{2} \mathrm{Cc} \times \mathrm{e}_{2} \mathrm{Cc}$. } \\
\hline \multirow{2}{*}{$\begin{array}{l}54 a \\
65 \mathrm{c}\end{array}$} & $40: 625$ & . & & $\ldots$ & & $\ldots$ & . & \multirow[b]{2}{*}{2} & 3 & \multirow{2}{*}{ I } & \multirow[b]{3}{*}{$\begin{array}{l}14 \\
14\end{array}$} \\
\hline & $45: 210$ & $\cdots$ & & & $\ldots$ & $\ldots$ & $\ldots$ & & 3 & & \\
\hline \multicolumn{2}{|c|}{ Sums....... } & & & & & & & $\begin{array}{l}6 \\
3 \frac{1}{2}\end{array}$ & $\begin{array}{l}6 \\
7\end{array}$ & $\begin{array}{l}2 \\
3 \frac{1}{2}\end{array}$ & \\
\hline \multicolumn{12}{|c|}{ ClaAs $29 .-\mathrm{e}_{2} \mathrm{Ce} \times \mathrm{e}_{2} \mathrm{C}_{2}}$. \\
\hline \multirow[t]{2}{*}{$5 \mathrm{ra}$} & \multirow[t]{2}{*}{ I8: $17 \mathrm{I}$} & $\ldots$ & $\ldots$ & & $\ldots$ & $\ldots$ & $\ldots$ & $\cdots$ & 2 & 2 & 4 \\
\hline & & $\ldots$ & . & $\ldots$ & $\ldots$ & $\ldots$ & $\ldots$ & . & 2 & 2 & 4 \\
\hline
\end{tabular}

3. DISCUSSION OF TABLE C; THE APPARENTLY UNCONFORMABLE CASES.

Class I: When both parents are liable to excited spells without corresponding depressed spells, children of the same sort are expected. Only one mating of this kind was available. The father was subject to sprees and killed himself by drinking poison (probably, but not certainly, in an excited state). The mother had acute mania, was noisy, violent, and destructive. The son is very alcoholic, hypererotic, and choreic - the eroticism and chorea being dominant traits. The daughter is also hypererotic, restless, and subject to choreiform twitchings. This brief history is one of prevailing dominant excitement and lack of emotional control in all members.

Class 2: In this class of matings a person of choleric temperament is mated to a person of nervous temperament. There are seven matings of this sort. All but one follow the expectation of being either choleric or nervous, and he is recorded as "normal." His mother was in a hospital on account of "chronic mania," and the father was hypererotic. The daughter was also an institutional case with a history of excitement (with epilepsy). Of the son we have only the record that he was reliable and slow. I enter him as normal with much doubt.

Classes 3 and 4 require little comment. Class 5 is that of the mating of a man of terrible temper with a good-natured woman; of their children one is quick-tempered and became violently insane and suicidal, 
factor, even though simplex. The case of $82 c, I V-4$, who is stated to be even-tempered and well-poised (despite the extreme excitement of his mother), is exceptional; but this result will occasionally appear when the hyperkinetic parent, though very excited, is actually simplex. I have let the case stand in this class in order to avoid the charge of manipulation to make observations agree with expectation.

Classes 7 to 10 offer no special difficulties. In class I I, mating $2 a$ demands consideration. The eldest son (III-I) of a maniacal mother, is less excited than she, but still so excitable as to threaten suicide; so he is charted and tabulated as being duplex in the exciting factor, doubtless the complete dominance of the single dose. However, in this fraternity are 2 other individuals that have to be recorded as normal. III-3, who is "cordial and coöperating;" III-II, who is "thrifty, sociable, and kindly;" and possibly III-9, who is recorded as good-natured, pleasant, and generous, but these adjectives suggest a rather expansive temperament. Rather than to force the first two cases into the nervous group (to which by hypothesis they belong), they are recorded as (exceptionally) normal individuals.

In class 12 we have probable complete dominance of the simplex condition; but also a normal person, "calm, dignified, and reserved," when none is expected.

In class 14 the son of a manic-depressive is "temperate, agreeable, pleasant, and kind." This son is still young and his mother first showed her traits in exaggerated form relatively late in life. This may be only an apparent exception.

Class $2 \mathrm{I}$ is the largest of all except class 24. The relation of observed and expected is fairly close in most of the divisions, except that there is a striking deficiency of the cholerics and a corresponding excess of the normals and the manic-depressed. Some, if not all of these deviations from expectation may be chance. In class 24 the relations are fairly close.

To sum up, out of 629 offspring we have 6 normals recorded where they are not expected by hypothesis. All other exceptions (5) are of the order of complete dominance of a simplex determiner for excitement. The proportion of non-conformable cases is thus 0.95 per cent. It seems to me that a hypothesis that fits the facts so closely has a very high degree of probability in its favor. At any rate, it meets the pragmatic test; it works! Actually, of the I33 offspring of a manic parent all are excitable except the 6 normals. When neither parent is excitable none of the children are excitable (classes 28 and 29, I 8 offspring, I 2 more or less depressed). When neither parent shows depression the children rarely do (classes I, 2, 5, 8, I5, and I $8 ; 5^{2}$ children). When one parent shows melancholia and the other carries no depression, then none of the children suffer from melancholia (classes 4 , $7,17,20$, and $26 ; 21$ offspring). While we may grant that the number 
of cases is unfortunately small, still the results are clear-cut enough to justify drawing conclusions as to the danger or innocuousness to offspring of given matings.

Though the hypothesis that we have applied seems to fit the facts satisfactorily, it is desirable to consider other possible hypotheses.

First, we may consider the hypothesis that there are no inheritable factors in temperament, but that family resemblances are due to imitation or suggestion. The principal fact that seems to nullify this hypothesis is the great dissimilarity of the children of one fraternity under certain conditions; $e . g$., of class 21 or class 24. Again, if this hypothesis were true, we should expect some of the children of a melancholic parent mated to a non-hypokinetic to show melancholia themselves; actually, the influence of the suggestion of the melancholic parent is not sufficient to overcome the opposing lereditary tendencies.

Second, there is the hypothesis that temperament, like "criminality" or "insanity" (in its broadest sense), is too complex a thing to be explained by any possible laws of heredity - is an end-result due to numerous dissimilar canses - a mixture of heredity and environmental factors. This may be called the popular view; it is a view that I was prepared to accept if no simple heredity hypothesis would fit the facts. Even yet I find it difficult to get rid of the prejudice that example, teaching, experience, and state of health may do much to modify one's behavior. Behavior is, indeed, reaction to stinuli; conditions modify reactibility, irritability; the nature of the stimulus determines (within limits) the reaction. An habitually constipated person is, we are told, apt to be a gloomy person; also one person may work off by hard labor or walking a hyperkinetic tendency that in a more sedentary person shows itself in violent behavior. Also, the social pressure for selfcontrol is much stronger for persons of a certain social status than for others.

Certain facts must, however, be regarded in appraising these considerations:

First, immediate "causes" of depression or excitation, such as constipation or suprarenal hypersecretion, probably depend in part upon an hereditary factor.

Second, a life of muscular activity as opposed to one of sedentariness is also determined in part by an hereditary factor. It is not morcly the necessity of earning a living that keeps the clerk chained to his desk; he earns in a month as much as a tramp does in a year; but he has no desire to wander the other I I months, if the hereditary nomadic tendency is absent. And, again, while the importance of social pressure is not to be neglected, experience indicates that it does not keep from depression, melancholia, or suicide, nor repress the jovial, garrulous disposition. As Galton (I8S9, p. 237) says: "Persons liighly respected for social and public qualities may be well known to their relatives as 
having sharp tempers under strong but insecure control, so that they "flare up' now and then." As a matter of fact, it is commonly recognized that temperament is largely inborn and is prevailingly determined by heredity.

Third, admitting the hereditary factor in temperament, various hypotheses are tenable. Galton's (I 899, p. 235) statistical discussion is not interpretive and can not be translated into modern biological language. I sought originally to fit a simpler set of factors to the facts than those here employed, but nothing simpler would meet the conditions satisfactorily. But perhaps our hypothesis is too simple; there may be more hereditary factors than I predicate. There is an a priori probability in this hypothesis. Let us consider it.

If there is only one gametic factor for excitation, $\mathrm{E}$ (its allelomorph being e), then when both parents are simplex for this factor the factors should appear in the children in the proportion of I duplex, 2 simplex, and I nulliplex. An inspection of classes 15, 16, 17, 21, and 22 shows that of the offspring there are 47 duplex, I I 5 simplex, and 76 nulliplex, or nearly the ratio of $1: 2: 1 \frac{1}{2}$ or 68 per cent with the excitation factor and 31.9 per cent without; this is a considerable departure from the expected $3: \mathbf{I}$; being about $2: \mathrm{I}$.

Similarly, if there is only one gametic factor for $\mathrm{C}$ ( $\mathrm{c}$ being its allelomorph) in each parent, we should expect the condition of $\mathrm{C}_{2}, \mathrm{Cc}$, and $\mathrm{c}_{2}$ in the offspring to be in the ratio of $\mathrm{I}: 2: \mathrm{I}$, or $\mathrm{C}$ to no $\mathrm{C}$ in the ratio of $3: \mathrm{I}$. Actually we get $9 \mathrm{I}: \mathrm{I}$ IO : 73 , or 73.3 per cent to 26.6 per cent, or close to the ratio of $3: 1$. In some respects this is a better fit than with the excitation factor but in other respects not so good.

In the matings $\mathrm{C}_{2} \times \mathrm{Cc}_{\mathrm{c}}$ we expect $5^{\circ}$ per cent normal duplex and $5^{\circ}$ per cent simplex; actually the numbers are 89 cheerful to 45 phlegmatic; but doubtless many "cheerful" are really simplex, but appear as normal because of complete dominance. In the matings $\mathrm{Cc} \times \mathrm{c}_{2}$ the ratio is $79 \mathrm{Cc}: 68 \mathrm{c}_{2}$, which is fairly close to the expected $\mathrm{I}: \mathrm{I}$ ratio. If we combine the "back-crosses" of simplex-excited on duplex-excited and on nulliplex-excited, we get an approach to the ratio of equality.

Now, although in many of these tests the observed ratio is not close to expectation, yet this ratio is more closely approached than any other simple ratio. Thus the ratio e to $\mathrm{E}$ and $\mathrm{c}$ to $\mathrm{C}$ in $\mathrm{F}_{2}$ never approaches $\mathrm{I}$ in $\mathrm{I} 6$. It is fairly close to $\mathrm{I}$ in $4(i . e ., \mathrm{I}: 3)$.

While I do not wish to insist that the hypothesis which fits so surprisingly well tells the whole story of the hereditary factors involved in temperament (and the whole story can be known only after much more and more analytical data have been analyzed), still it can not be denied that it fits the facts approximately, and no other hypothesis that has been tested serves anything like so well. 


\section{THE BEHAVIOR OF THE CHOLERIC.CHEERFUL.}

To illustrate the criteria used in assigning an individual to a zygotic class there are brought together in this section all descriptions of parents and children assigned to the class, choleric-cheerful. Similar tables may easily be drawn up for each zygotic class from the legends accompanying the charts; but it seems scarcely worth while to publish the tables.

$31 a, \mathrm{~F}$. Subject to sprees; suicided with poison.

M. Had acute mania; violent and destructive.

Son. Sx; restless and twitches.

$1 b$, F. Surly and disagreeable; was hypererotic and brutal to wife and children.

Son. Has a swaggering air and manner; ran away from home; put in a reform school for rape.

Son. Wild and hot-tempered; profane and ugly toward his wife; takes whisky regularly to forget his business worries.

Son. Jailed at it years for rape; hung himself.

$3 a$, M. Rough and uncouth; easily excited, passionate; has fits of temper.

Dau. Was Sx; attempted to hang herself; flew into fits of temper; was slovenly, seclusive, indecent; at 32 had delusions of being poisoned; threw herself out of window.

$22, \mathrm{~F}$. Cut his throat with a razor.

Son. Cut his throat as his father did.

$28 a$, M. Garrulous; jumps from one topic to another; las sudden emotional changes; said to have attempted suicide.

Dau. Had a nẹrvous breakdown twice; is very hot-tempered; jumps from one topic to another.

Dau. Had delusions of persecution; threatened her neighbors; had hysterical attacks.

Dau. Attempted suicide at 16; was disturbed and hysterical at 19; had suicidal impulses.

29a, F. Excessively alcoholic; Sx; assaultive; killed himself by lianging.

Son. Excessively alcoholic, suicidal, and homicidal; cut his throat twice; stabbed at landlady; was excitable and violent.

$35 b, F$. Alcoholic; at 48 became excited, talkative, expansive; had schemes for making money, and was emotional; wanted to shoot someone and was noisy and assaultive.

Dau. Became irritable, violent, restless, destructise; at hospital very flighty and destructive; diagnosis: mania.

$37 a$, M. At 20 had delusions; was noisy and quarrelsome; at fo (fourtls admission to hospital) was very excited and made threats of violence; diagnosis: clironic mania.

Dau. Epileptic in youth; at 46 was delusional and hallucinated; at one time excited, restless and appreliensive.

$82 b$, F. Alcoliolic in youth; became maniacal, chased family out of doors, flourished a razor, tried to shoot his wife; had a religious mania.

Dau. Hot-tempered, violent, excited, religious; threatened to cut her own throat and shot herself.

Son. Violent, confused, and later demented.

$43 a, \mathrm{~F}$. A shiftless, wortliless epileptic, at times riolent and resistive; ugly and jealous, threatening his wife. 
$27 c, \mathrm{~F}$. Very nervous and cross; has a terrible temper.

Son. Subject to convulsions; had violent outbreaks of temper; was brutal to animals; became violently insane and suicidal.

r $a$, F. A great fighter; of ugly, disagreeable disposition.

Son. Became wild and reckless; reproached by his sister, he said he would not stand that, took some "Rough on rats," and died at 19 years.

I $3 a$, Son. Was easily excited; lively; not depressed; hanged himself.

Dat. Quick-tempered; musical.

Dau. Bright and happy, but a little peculiar; committed suicide at 35 .

$2 a$, Dau. Became violently insane at I 7 ; put broken glass in a pie that was being baked for the family; recovered; naturally jolly and kind.

$9 a$, dau. An actress who is obstinate, irritable, and passionate; after childbirth she became deranged and is now obstinate, silly and shameless; has attempted suicide.

I $2 a$, dau. A great talker; at 3 I became violent, restless, noisy; developed delusions and hallucinations and threatened to commit suicide.

Dau. Contrary and stubborn; hyper-religious; became noisy, restless, sullen, and had delusions.

I $3 d$, son. Impulsive, irritable, and passionate; became excited; attempted to shoot himself.

Dau. Quick-tempered; at 32 became excited; had acute mania.

$18 a$, son. Alcoholic, cross, irritable; at 37 threatened suicide; was excitable; had delusions and hallucinations.

Son. Quick-tempered, had delirium tremens and hallucinations.

$27 a$, son. Sulky and impatient as a boy; drank; quick-tempered, homicidal, and suicidal; has hallucinations and delusions.

$46 a$, dau. High-tempered, extravagant; became insane and jumped out of window, killing herself.

Son. At 20 became erratic, silly, irresponsible; wanted to travel and follow girls.

$26 b$, dau. Obstinate, irritable, and passionate as a child; became hysterical and tried to hang herself and kill her child.

NoTE.-A considerable range in kind and degree of behavior will be noted in the foregoing list; in a few cases the classification may be said to be in doubt, but in such cases it is (for the testing of the hypothesis) immaterial. Taking all things into consideration, the assigned classification seemed the most reasonable.

\section{CONCLUSION.}

It is morally certain that temperament in man is "determined" by a pair of hereditary, germinal factors, namely, a factor for-excitation whose allelomorph is absence of excitation or placidity; and a factor for normal cheerfulness whose allelomorph is absence of cheerfulness or depression; that these factors may be inherited independently of each other; that dominance is ordinarily imperfect, so that two doses of a factor give a more pronounced result in the offspring than only one dose; that (with rare exceptions) the offspring of two manic parents are excitable; of two placid parents are not excitable; of a depressed and a non-depressed are not depressed; of two depressed are all depressed. 


\section{DISCUSSION OF EARLIER STUDIES ON HEREDITY OF TEMPERAMENT.}

The earliest and, so far as I know, the only previous attempt to analyze the hereditary factors in temperament in general was made by Galton (1 889, pp. 226-238). But his group of "bad temper" included such opposite moods as "choleric," "decisive," "fits of anger," "headstrong," and "impetuous" on the one hand, and "gloomy," "morose," "sullen," on the other. His group of "good temper" includes not only calm, equable, placid, self-controlled (our "normal"), but also "amiable" and "buoyant" (our "nervous"), and also submissive and timid (probably phlegmatic). With such an unfortunate association of dissimilars it is not strange that he did not get clear-cut results. Where both parents are "good-tempered" 30 per cent of the children were "good-tempered" and Io per cent bad-tempered; the rest (6o per cent) being of neutral temper. Where both parents were "bad-tempered," 4 per cent were good and 52 per cent bad-tempered, 44 per cent being neutral. Just what neutral means is not explained; probably it includes two groups-those of mixed temperaments and those whose temperament is not fully given. On the other hand, many studies have been made on emotional insanity, $i$. $c$., of the manicdepressive group. That insanity of the emotional group is inherited has long been recognized. Burrows (I S2O, p. 9) says:

"There certainly is no physical error in accounting insanity hereditary. Had the knowledge of this fact merely led to a closer inquiry respecting those with whom a connubial union is contemplated, it would be a commendable foresight, often conducing to the preservation of domestic bliss now too frequently interrupted by the development of this dreadful affliction in the object, perhaps, of our tenderest affections."

Lucas (I850) devoted a considerable part of his work to heredity of mental disorders, and in the latest edition of his Psychiatrie, Kraepelin (r 909) devotes over Io pages to heredity, and gives a brief bibliography of writings on the subject from $\mathrm{I} \$ 93$ to 1907 . Kraepelin observes that:

"The various forms of mental ailment are influenced in very different degree by the hereditary factor. Its action is naturally most evident in those disturbances that arise from internal causes. Here belong manic-depressive insanity, the epileptic and hysterical mental disturbances, moreover, nervousness, obsessions, impulsions, sexual perversions, the different forms of diseased personalities; finally, also, paranoia."

The circumstance that manic-depressive insanity is regarded as being more "influenced by heredity" than dementia precox would suggest that it, or some of its elements, are dominant. Rosanoff and Orr (I9II) entertained the hypothesis that the so-called functional psychoses may be considered to depend upon a single heredity factor, and their data seem to support strongly the hypothesis. The paper marks a great advance because of the quality of the data and the method of analysis. Rosanoff reached the conclusion that the func- 
tional psychoses are dependent on a recessive factor, and Rudin (I9I I) confirms this conclusion for certain forms of dementia precox in certain families, but thinks many manic-depressive disturbances in many families suggest a dominant method of inheritance. Jolly (1913, p. 27o) finds that for affective psychoses, the hypothesis of a simple, dominant heredity must be rejected; but it seems to him that a sexlinked heredity is not excluded, also it is possible that there may be a recessive method of heredity; and for dementia precox a simple recessive heredity may hold. Wittermann (19r3, p. 264) concludes that the predisposition to dementia precox is recessive. That there is a difference in the nature of the hereditary factors in emotional and demential psychoses is indicated by many additional facts. Thus Jolly (19I3) finds that a manic-depressed parent is twice as apt to have insane offspring as a schizophrenic parent. In 7 "manic-depressive" families studied by Schuppius, in which at least one parent was known, one parent was "insane" in I case; "depressed," 2 cases; inclined to suicide, I case; peculiar, I case, and a senile dement, I case. Also in the instance where a parent was "insane," 2 manic children had 3 "insane" offspring. In a case studied by Albrecht (I9I2, p. 564), mother and daughter both have manic excitation; in another family a "queer" mother has a restless, litigatious son who, by a neurasthenic wife, has a nomadic, excitable daughter who has occasionally epileptic attacks; in another family the mother shows hypomania and later full mania and her daughter had a marked manic attack; in another family (p. 566) the mother at 58 broke out, sang, prayed; in the hospital she had impulsions to move and talk; she tore up laundry, heard the voice of Jesus, etc. ; her daughter, at $2 \mathrm{I}$, ran from the house crying; prayed and heard voices. Mobius (I884) gives several pedigrees like this: first generation, man died of delirium tremens at 50 years. His daughter was excitable, energetic, somewhat fantastic. Of her 4 children who grew up, $\mathrm{I}$ is excitable, fantastic; $\mathrm{I}$ has fits of temper and melancholic spells; and I other (a son) has a bad temper. Of the latter by an hysterical woman 2 out of 4 children had convulsions in childhood, and I of them died in the fits. Again, an intelligent but peculiar, nervous, choreic man by a normal woman of neuropathic stock has $(a)$ an hysterical daughter who has 2 "hysterical" and I nervous-excitable children; $(b)$ an hysterical daughter whose daughter in turn is nervous; and $(c)$ a son of variable mood, all three of whose children are nervous, one also "excitable," and one with a tendency to melancholia. Again, a man, who had anxious attacks, by a normal wife had $(a)$ a peculiar daughter who had 3 nervous children (I with mania); also (b) a nervous daughter who married her nephew and had a daughter who is chronically insane. In all these cases we have to do with nervousness that does not skip a generation-and it is of the dominant type, $i$. $e$., hysteria and mania-either simple or combined with depressions. In Wittermann's work there are some families with 
hereditary hyperkinesis. Thus (p. 233) in family $\mathrm{F}_{2}$ the grandmother after the death of her insane sister was greatly agitated and filled with self-reproaches. Her daughter had periods of great excitement after some irritating incident. This daughter's daughter is somewhat nervous; has spells when she can not sleep well. Again (p. 235), in family L, the great grandfather accumulated grcat riches; his son was very excitable and married a woman who had involutional melancholia. This son's son, Johann, was very frivolous, haughty, erotic, boastful. Admitted to a hospital, he was unusually active, wrote countless letters, was euphoric and boastful. The Wasserman test was negative and the patient was eventually discharged improved. This man married a woman of normal stock, so far as known, and his son, Johann, became (at about i 8 years) excitable and delusional. In hospital, rose early, wrote many letters, composed verses, was very divertible. 'The brother of this Johann $2 \mathrm{~d}$ married L. ; was attacked with motor unrest, wandered about. Admitted to the hospital, he had delusions of having made great discoveries, showed an elated mood, but soon recovered and was discharged. In all these cases the clated mood is repeated in each generation without a break. All these cases, then, support the view that hyperkinesis depends on a dominant factor.

The inheritance of hypokinesis is not, from the nature of the case, so clear as that of hyperkinesis. By hypothesis, the hypokinetic factor is recessive to normal or to hyperkinesis. So we may expect hypokinesis to appear in the children when it is not shown by either parent. Under such circumstances it should affect only a small fraction of the children; but, on the other hand, evidence of the hypokinetic tendency should appear in the close relatives on both sides of the house, as, indeed, it usually does. It appears probable that the reason for the contrast between Rudin's findings and those of Rosanoff and Orr lies in the fact that the hypokinetic state is inherited differently from the hyperkinetic. For Rudin finds that, in some manic-depressive families, inheritance of the psychosis is of the dominant sort as we find is the case with mania, while Rosanoff and Orr find the manic-depressive tendency to be recessive, as we find is the case with depression. But while, on the whole, the data presented by Rosanoff and Orr (1911) speak for the recessive nature of the psychoses that they deal with (largely dementia precox and depressions), yet some families show the dominant inheritance of hyperkinesis. Thus in their chart 39 the grandfather had a violent temper, became violently insane, had to be tied down; his son had a violent temper, "always fighting," and of his children, in turn, 3 have a bad temper. In chart 68 the grandfather was insane, his son eccentric, high-strung, and 3 of this son's 4 children are easily excited or friglitened. In chart $7 \mathrm{I}$, the grandmother was "ecentric," probably insane; her daughter ececntric, miserly, probably insane; and their daugliter's daughter miserly, "like her mother," had spells of yelling; insane. "This case, then, illustrates the sane rule of dominance of lyyperkinesis. 
An examination of the literature of insanity reveals much indirect evidence of this difference in inheritance of hyperkinesis and hypokinesis, and some authors have duly appreciated the fact.

Thus Stelzner (1906), in an analysis of the inheritance of 200 suicidal women, finds that in 65 cases of suicide with melancholia, one parent of the suicide is insane or depressed in 4 cases or 6.I per cent, while, on the other hand, in the 32 cases of suicides with an hysterical psychopathic constitution at least one parent is insane or psychopathic in 14 cases (in one case for 2 generations) or 44 per cent. In the first group "heredity" is unknown or doubtful in 47 out of 65 cases (or 70 per cent), while in only 15 out of 32 in the latter group is heredity unknown or doubtful (or 47 per cent). These differences are what one expects between a trait with indirect and one with direct heredity.

Let us now consider, seriatim, some special family studies of the manic-depressions, to see how they bear upon our conclusion. Berze (rgo9) studied the family $H$. The propositus (child $\mathrm{I}$, born in $\mathrm{I} 843$; married I 870) was in later years repeatedly of such disordered mood that she could not attend to her domestic duties. She was admitted to the hospital in 1892 with a chronic delusion which had probably long pre-existed. During the 16 years that she was under observation at the hospital her condition underwent no intermission or remissionthere was no change of mood from gay to grave, but she was constantly happy, euphoric. In later years she had a slight inclination to a condition of anxiousness, and, when free from it, to a certain angry irritability. She shows many hallucinations - the confabulations but not the systematization of delusions; she shows absence of emotions and profound impairment of psychic behavior; is disoriented and permanently deteriorated. Her brother, child 2 (born I 847), shows a typical alternation of mania and depression and has undergone these changes 7 times. $3-0^{7}$, died at 4 years of diphtheria. $4^{-9}$, shows repeated loss of mood, but is not in an institution. $5^{-\%}$, born $185^{\circ}$, at 22 years had a depression; in I 888 she showed great excitement, talked much, tore her clothes, was cruel to the maid (who left), and was sleepless and restless at night. At the hospital she showed clear mania, was restless, threatened others, complained a great deal, and became excited in the next few weeks. In August and September she was confused, noisy, aggressive; in October quieter; in December still better, and was discharged in February. This woman has two daughters, of whom the elder at 25 years was hyperkinetic in the summer of 1907 , melancholy in the autumn, then hyperkinetic in the spring. The other daughter shows a prolonged hypomanic condition, with the picture of "moral insanity." 6- 9 , born I $85^{2}$, in her twenty-sixth year was disturbed in mood and died 3 years later. $7-q$, born 1856 , first showed mental symptoms in 1875 . In the hospital in February with maniacal excitation, she cried, laughed incessantly, was irrational in speech, dis- 
arranged her hair, tore off her clothes, and was erotic. In April sle was more orderly; in May quieter. She married in 1876 a man who states that she has a "very lively temperament." In December 1882 she appeared to overdrive; in March she went to the hospital; the mania increased, she declaimed, made faces, and gesticulated. After a fit of temper she was theatrical, tore her hair, threw furniture about, threw food and china at attendants. In May the excitement diminished, and she was discharged in September. $8-\%$, died at 18 years of heart trouble. $9-\sigma^{7}$, born $185^{s}$, is somewhat inferior mentally, at times very coarse and given to drink. The inferiority shows itself not so much in intelligence as in insane, almost brutal, pranks. Io- $\sigma^{7}$, born 1862, in I 888 became infected with syphilis; in I894 showed hyperkinesis; placed in an institution in I 895 with melancholia; in the hospital was sad, tearful, depressed, and died in 1896 with a diagnosis of circular insanity.

In discussing this family Berze says: "Thus we see that of the 8 psychiatric sibs, 7 are more or less certainly to be considered manicdepressive." The exception ( $\mathrm{I}$ ) is discussed and the conclusion reached (p. 287) that "certain accidental personal causes are able to displace or rather to overshadow the influence of the inherited disposition to such an extent that psychoses arise which can not be regarded members of the same hereditary group."

Of the foregoing family the mother was repeatedly insane and also repeatedly in a private sanitarium for the insane; she was sometimes elated, sometimes sad ("circular insanity"). The mother's mother was a maniac. The father and the father's father were mentally sound. Note that, in this case, the insane tendency can be traced back for three generations, as is typical of the ancestry of the hyperkinetics.

Nitsche (1910) described I 2 cases of chronic mania and gives the parentage of some of them. Of No. I the mother has violent temper, is very loquacious and vindictive. Of No. 2 the father liked to undertake new enterprises, was dogmatic, stood $n$ contradiction, frequently threatened suicide, and finally lost all his property. Of No. 3 the father was insane. No. 4 was of illegitimate origin, parents unknown; so, too, No. 5. Of No. 6 the mother is insane. Of the family of No. 7 little is known. Of No. 8 the father is a neurasthenic and very excitable. Of Nos. 9 and io the family is said to show no other insane members, but no details are given. Of No. i the father is a well-known poet. Of No. I 2 the father has a very lively temperament, is very energetic, etc. Thus of the I 2, 7 have a hyperkinetic parent (if we may include the poet!), and details are lacking about the other 5. Nitsche's study thus supports the view of the dominance of lyperkinesis.

Thus the studies of others confirm our conclusion that lyyperkinesis is dominant in heredity, while hypokinesis is recessive. ${ }^{1}$

'Confirmatory also are the results of Verkes (191.3) on hyl,ricls ixetween savage and tame rats. 


\section{EVIDENCE FOR HEREDITY OF TEMPERAMENT DRAWN FROM STUDIES OF IDENTICAL TWINS.}

Since temperament is inherited, we can understand the cases, so often cited, of similar mood in members of the same fraternity, and especially in twins. Thus, Chatelain ( $188_{3}$ ) tells of twin sisters who resemble each other to a striking degree and have lived together for 74 years. In 1872 one of them lost her husband. Both were seized at the same time with the same form of melancholia, and recovered at the same time. Last spring the husband of the second died, and the same seizures occurred again.

Gill (1883) describes twin sisters who were extremely alike in personal appearance, in manner, style, and speech, so that they were easily mistaken for each other. They had similar illnesses at the same time, even on one occasion when they were far apart and had not communicated with each other.

The sisters kept a lodging-house together. One, Mary, looked after the domestic affairs; the other, Alice, was a milliner. Their two brothers are feeble-minded and one has had an excited attack. An elder sister has periodic depression and a younger sister is willful, ungovernable. On November 20, I879, Mary was admitted to the hospital, restless and loquacious; then highly erotic in her delusions, talking of men and marriage and alleging assault on the part of one of her lodgers. Symptoms diminished until December 29, when excitement increased, with violence, destructiveness, and increased delusions; after January 5, I880, Mary showed improvement; was flighty again in May, and discharged recovered in October 1880 . In December I 880 she was readmitted in a very depressed state, which was later replaced by violence; she also had some sort of an unconscious spell. She improved until November I88I, when she became very talkative and liked to decorate herself; was convalescent in March I882; was maniacal in July $\mathbf{I} 882$, and has continued so until the time of reporting in November 1882 .

Alice was admitted to the hospital on December 29, 1879, suffering from exactly the same form of mental disorder as her sister; has many delusions of assault and persecution. She dressed fantastically, laughed, sang, shouted, and acted erotically. In March I880 the patient was discharged recovered. On September 13, I88I, Alice was readmitted with an attack of well-marked hysterical mania, the symptoms of which were very much like those of her first attack, only worse. She improved until November 2I, when she again had a very maniacal attack, from which she began to recover, with short relapses, and was discliarged October I6, I882.

The nature of the two disturbances experienced by the sisters is thus remarkably similar; but those of Alice had a shorter period. 
The following account (from Fflintoff, i 883) of imbecile and excitable male twins, aged 40 , is given in parallel colunns. There was a great mental resemblance between them. Their father was insane, but 110 insanity was learned of on the other side of the house.

$$
\text { A. 1). }
$$

Very childish in manner, is easily led and induced by others to do wrong; is very cumning, mischievous, and takes a great delight in committing petty acts of theft. His memory and judgment are very defective, and he can not form an opinion on any subject with which he is not familiar, nor has be any idea of his age; but he converses a little and knows the people with whom he associates daily. When not allowed to do as he wishes he frequently becomes very passionate and can scarcely control himself; usually he is quiet and fairly well behaved.
II. II

Not so ethildish as his l,rutler. lunt witer sulks, is very dejraved ansl vicions, and more cumning than the other. He frectuently commits petty acts of theft. Ilis mentury is weish and his judgment defeclive, ant he ean not give an opinion on a sulject with which he iv not familiar, nor does he knuw his age, but lie can converse in a simple way and knows the people with whon he associalcs. He is irritable and very passionate and uccassionally. when thwarted, gives way to fits of ungovernable rage, amounting nearly to sliort maniacal attacks, but he is usually fairly well hehaved.

In I884, Fflintoff described a case of sinilar twins who showed a similar melancholic attack.

Moreau (quoted by Euphrat, i 888) described twin brothers who are outwardly so alike that they are easily taken for each other. Their characters are no less alike. Both are persecuted by the same fiends who are planning to work their ruin by the same means. Both have the same hallucinations of hearing. They sit in the same corner of a room, melancholy and silent, and respond only with difficulty to questions which are put to them. They never communicate with each other. At irregular intervals of 2 to 3 months both rouse up at the same time, often on the same day, from their stupor, make the same complaints, and beg the doctor for their discharge. This is all the more noteworthy, as they are many kilometers apart, the one at St. Anne, the other at Bicêtre.

Savage (1883) describes two sisters who are very much alike in personal appearance. Both patients are typical cases of melancliolia with stupor. They stand about unoccupied, and without care or attention to appearance or to necessities. There has been 110 case of insanity in the family as far as can be ascertained, and the causation of the taint is unknown. Since admission the cases have been placed in separate wards, but still the progress has been very sinilar in both; at present both are beginning to look about then and to say a word now and then. The two women had left their parental home, and had homes of their own. Details of these sisters are as follows:

"Case I.-A. S. U., 28. Admitted Angust 14, 1SS2. A farmer's wife. Three cliildren; youngest, 10 montlis. Iijirst attack; duration, two weeks. The supposed inciting cause is the slock of seeing her sister suffering from melancholia. Stated to be suicidal, but not dangerous. Sober and welleducated. 'lemperament, quict. Iarliest symptoms: excitcment and talkativeness, crying out that God has taken her lieart, and that slie lias sinned very grievously against Him. Present condition: Is never found sitting; 
stands with her hands in front of her for hours, never speaking; is with difficulty induced to take her food.

"Case II.-E. G. W., 28. Admitted August I7, 1882. An architect's wife. Three children; youngest, 8 months. First attack: duration, 9 weeks. Neither suicidal nor dangerous. Sober and well-educated. 'Temperament cheerful, placid, and industrious. Earliest symptoms: Had a fainting fit, and was semi-unconscious for a week, when she came to herself very depressed and melancholy. Present condition very much the same as sister; does not sit down or speak; has to be fed by spoon."

Cockayne (1911) treated homologous twins for the same, rather rare, symptoms of lienteric diarrhea. They were both quick and excitable and ate voraciously and rapidly. Under better conditions of eating and resting they both improved.

Cullère (I9OI) describes twin sisters, Célestine and Prudence, who both began to attract attention because of excitement at the age of 20 years. They were slow in learning to walk and to speak. At 17 both had terrible nightmares and hypochondriacal ideas. Célestine was the more active, with the greater impulsions to violence. In Prudence, who showed similar symptoms at about the same time, they had a more morose cast. Célestine felt that everyone was hostile and accused her falsely, and she especially cursed her mother for urging her to marry contrary to her choice. She would have crises of despair and weep. Prudence felt that the cure had bewitched her; that her uncle wished to force her to marry; that her mother did not love her. Like Célestine she would assault viciously; but would have crises of despair accompanied by tears and melancholy ideas. Both have gradually demented slightly.

Hasse ( 1887 ) describes homologous twin sisters of 26 years, one married, the other not. Both suffer from melancholia with great anxiety and a pronounced hysterical tendency, and a strong impulse to suicide. Both have hallucinations of hearing and sight.

Ostermayer (1890) treated identical twins, Emil and Arnold (born about i 870), whom he describes in great detail. From childhood they were most intimately tender toward each other; but they were illhumored, irritable, refractory, and never appeared happy. They were diligent at school, brought home the best of reports, kept away from their schoolmates, and tended to overestimate themselves. After finishing their studies both went to work; they showed themselves very ambitious, but unstable. In the late summer of I 887 Emil imagined the daughter of his employer was in love with him, and when this was demonstrated to be false he attempted suicide by poisoning, but was saved. He became melancholy and accused his mother with being the cause of his failure to marry the girl. Arnold, who was also out of employment, suspected his brother of taking a poison and secretly gave him antidotes. Einil entered employment again, but everywhere felt himself injured and persecuted, until he withdrew from aftairs and he and his brother deroted themselves with zeal to the study of languages, 
having determined to go to America. Meanwhile the idea developed in both that the mother was beginning to persecute them. Arnold left home to work in the metropolis; but here he suspected his landlady of pilfering money from him, and he grew suspicious of the soups that were especially prepared for him. He did not succeed in getting a place and suspected that his commercial teacher was working against him. Arnold returned home and found Emil now eating only cooked vegetables and fruit to avoid being poisoned. In January 1889 Arnold went to help his widowed sister; here he suspected his sister of sprinkling poison on his food, and one day secretly exchanged his portion for hers; and the poison demonstrated its power, to his mind, in that his sister after taking it boxed her children's ears. Returning home, both brothers devoted themselves to warding off impending disasters, especially poisoning. At length, towards the end of 1889 , Emil's suspicions were directed against Arnold, also; he grew more and more restless and expansive, and thought more of the work of the "cabalists." In February 1890 Arnold also developed a delirium of persecutory ideas and became also hyperactive. At last they were brought to the hospital in a state of mania, with paranoia. At the time of reporting, Emil had improved, but Arnold, whose development lags a few months behind his brother's, is still paranoical.

The following case (Schïtz, 1886) shows the similar alternation of mood in twin sisters (born about I846), of illegitimate origin.

Helène, in 1868, while visiting the hospital to see her sister, appeared strongly predisposed; was of a lively nature. In September 1870 she became melancholy and attempted suicide; married in October. 13y March 1871 she became more talkative and was normal by June. Shortly after became very exeited, had anger fits, extreme motor restlessness, eroticism, committed (1) to hospital, July $187 \mathrm{I}$. Became quiet and discharged in November. Child born March 1872. September 1872 excited and erotic again; committed (2) ; became more normal in December and discharged March 1873 .

September 1873 committed (3), discharged May $187+$; same course. Second child. A 1 ri $\}$ 1874 .

May 1875 committed (4), discharged August 31, 1875; same cause.

Between 1875 and 1878 same periodic variation of mood. In September 1878 she was separated from husband and became a man's mistress, was extravagant and restless; committed (5) to hospital September 1879 in a maniacal condition. By February 1880 she had become quieter; then becane depressed, and was discharged March 1883 .

In March $88 .+$ she becisme livelier, excitable, extravagant. Conmitted (6) to hospital.
Agnes, irritable as a child. Had a nervous fever in 1865 , with delirium, followed by degression. In $\$ 866$ became delirious for is time. At IEaster, 1868. she became excited. delirious and wis committed (t) to a hospital. She was loud and noisy; by June 1868 had become quiet and was discharged in July. In March 1872 she became excited and was conmuited (2). She was violent and delusional; but became quiet by December 1872 . and a nionth later depressed, with self-accusations. Discliarged June 1873 .

Again, April 1877, ower-exeited and noisy; she was connutted (3); broke winclow panes; beeame quiet by July 1877 , then depresserl. and was discharged in November.

Again excited in Angnst 8 878 and committed (4); violent, fantastic. 1)epressed in Jannury: and discharged April 1870 .

In March 188, again exciterl; commited (5); flighty: (quieted by July; depressed. selfaecusative; diseluarged in Ninvenuler

Admitted (6) in Octoleer 1882 with excitement. melancholia followedl. and recubery

Commitfed $(7)$ April is8. with sane his. tury.

Readmitted (s) Julv Iss.5. sanne history; now (Jaunary 1886 ) recoveriug from a depression.

It is to be noted that the sisters lived apart from each other and under very different conditions. Nothing is known of the parents. It 
is to be noted, further, that Agnes shows much deeper depression than Helène, who was always of a livelier nature.

Smith (1912) gives an account of twin sisters (Annie and Jane, born I 848) who became depressed, and eventually demented in late life. Annie married at 24 and Jane at 26 years; both were of a quiet, retiring disposition; their physical resemblance was marked. In I 892 Jane's husband fell desperately ill, she became depressed and was admitted to the hospital with melancholia, persecutory ideas, and auditory hallucinations. After 2 years she returned home improved; but was returned in 1904 deteriorated, and died there, I9II. Annie began to worry in I 895 (as her husband became unfaithful to her), but she was not committed. In 1904 she became deeply depressed; was placed in the hospital with delusions of persecution and of reference; a few months later she was discharged improved. She died in 1906.

In another case of two like twins, Mary and Ellen, both had a simple, shallow disposition, and both were religiously inclined. They graduated from the public schools and both became sales-girls. Ellen had depression with suicidal tendencies in November 1895 at the age of 22 years. She was admitted to hospital; later became excited, then quiet and was discharged in August I898. Was readmitted in an excited state in December 1898; discharged recovered, April I901; readmitted, maniacal, May I, I90I.

Mary first passed into a depressed state in 1896 , a year after Ellen had her first depression. This recurred in 1897 to a degree that led to her commitment. Later she became excited (flippant, stubborn, combative); then followed stupor and restoration to a normal mood, so that she was discharged in I90I. In 1904 a pretext was offered for another deep depression and she spent 3 months at the hospital. In 1907 she again became depressed and committed suicide at her home by inhaling illuminating gas. (Note the suicidal impulses in both Ellen and Mary.)

Tissot (1909) describes twin sisters (Angelina and Josephine, born 1849) who were admitted to the asylum on the same day. A sister of the father was ill-balanced, a brother of the mother was simple-minded. The twins have always lived side by side and their physical and intellectual life have been practically the same. Infantile diarrhea appeared in both at the same time at $2 \frac{1}{2}$ years; menstruation began in both on the same day at 16 years; periodic return was regularly at the same time, and both reached the menopause at 5o years. Educated only at home, they could give exactly the dates of birth, death, and principal events in the life of each member of the family. Their ideas are right, showing good judgment and especially good sense. Their intelligence did not develop normally, but reached the same degree in both. They had the same temperament, identical ideas, memories, and sentiments. Their physical resemblance was no less striking. 
Wendt (I 887) studied a case of identical twin sisters who became ill about the middle of their third decade with a slight mania. One of them was placed in a hospital and after 8 or 9 months discharged recovered. The second sister was shortly afterward brought to the hospital. In the symptoms of her illness, as in her outward appearance, she showed such a close resemblance to her sister that one might have been taken for the other.

Baume (1863) tells of the twin brothers, Martin and François, who lived, the former at Lorette and the latter 2 leagues away at Quimper. On about the $15^{\text {th }}$ day of January the twin brothers, who had placed their savings in a common box, were robbed of 300 francs. During the night of January $23^{-24}$, at 3 o'clock in the morning, they had the same dream. Each awoke with a start, exclaiming that he had caught the robber and that his brother was being hurt; and both danced and jumped on the floor in the same extravagant fashion. Martin, who lived with his grandson, attacked the latter, fixing upon him as the robber; his excitement was progressive; he complained of violent pains in his head; at 4 o'clock on the afternoon of the 24 th he went out and tried to drown himself in the river, but was prevented by his son; at 7 that evening he was received into the asylum, where he died on the morning of the 27th. Meanwhile François spent the day seeking for the robber; at 6 in the evening he came upon his brother struggling with the gendarmes; became much excited; complained of a violent pain in his head, and on the same day drowned himself in the river at the same place where Martin, unknown to him, had attempted suicide a few hours before.

The foregoing histories of twins, which are quite in line with, and doubtless largely inspired by, Galton's (1883) essay on the "History of Twins," bring out in clear light the almost complete dependence of temperament upon internal, hereditary factors. Since the same emotional peculiarities develop in twins who are separated from each other by miles or even oceans, $i$. $e$., who have undergone very dissimilar experiences, we are forced to admit that of the factors that determine mood the internal are the most significant. If a loss causes in me a profound depression, that is my specific reaction to sucli a loss. 'The loss is not the "cause" of the depression, but it permits my reaction to such a situation to show itself. A rat causes one reaction in a fox terrier and a different reaction in a collie dog. If the rat were the "cause" of the reaction both dogs would act alike. The rat merely starts a train already laid in the terrier; it starts nothing, because there is no train laid, in the collie. Similarly must we account for the differences in the reaction to the same outward event made by two persons. The hereditary predisposition is always determinative. The great weakness of the Freudian as a general explanation of emotional psychoses is that it lays too little stress on the constitutional factor. 


\section{SELECTION OF TEMPERAMENTS IN MARRIAGE.}

Of the 29 classes of matings recorded in table $\mathrm{C}$, some contain many more entries than others. Thus classes I, 3, 4, 5, 7, 8, 12, 26, and 29 include each only one mating, while classes 2 I and 24 contain 22 and 20 respectively. Why this inequality in the frequency of matings in the several classes? There are various hypotheses that are tenable. Thus (a) since, as table A shows, in random matings certain gametic combinations will probably be less common in the whole population than others, such rare factor combinations may be expected to occur rarely in mating combinations. Such relatively rare combinations are $\mathrm{E}_{2} \mathrm{C}_{2}$, $\mathrm{E}_{2} \mathrm{c}_{2}, \mathrm{e}_{2} \mathrm{C}_{2}$, and $\mathrm{e}_{2} \mathrm{c}_{2}$; obviously the union of two individuals, both of whom are of these least common types, should be least common. Of the 9 classes which contain only I entry each, 3 are of matings of these relatively rare combinations. May not the variations in frequency of matings in the various classes be fully accounted for by a difference in frequency of the parental zygotic combinations? The test of this hypothesis will be found by noting if all matings of parents belonging to classes of equal frequency are equally common or nearly so. This comparison of theoretical and actual frequency of matings has accordingly been made and results are given in table $\mathrm{E}$.

Table E demonstrates, indeed, as might have been anticipated, that matings occur more rarely between two persons who carry the rarer zygotic combinations than between those that carry the commoner combinations. Indeed, except for the fact that group $\mathrm{x}$ in table $\mathrm{E}$ has an unexpectedly small number of matings and group 5 a somewhat unexpectedly large number of matings, the number of the matings in the different groups is proportional to the product of the numbers I, 2, 4, which are the most probable frequency-proportions of the least, mid, and greatest frequency, respectively, of the given zygotic combinations as shown in table $A$. Perhaps the most striking fact is that the mating $\mathrm{e}_{2} \mathrm{C}_{2} \times \mathrm{e}_{2} \mathrm{C}_{2}$, or both parents calm-cheerful (or normal), is not represented once in our 146 matings. This is, however, easily understood when the nature of our material is considered; the great mass of it starts with institutional cases of excitement or depression (or both), and a search was made in the volunteer records of such as showed such extremes of emotional disturbance. The zygotic factors of both parents of the disturbed persons are, by hypothesis, not normal.

When, now, one examines the relative frequency of matings inside of one group, in place of the expected equality of the frequency one finds great diversity. Part of this is chance; some of it strongly suggests a selection in mating based on temperament. Thus in group 2 the mating $\mathrm{EeC}_{2} \times \mathrm{E}_{2} \mathrm{C}_{2}$ (nervous-cheerful mated to choleric-cheerful) is far the commonest, the mating of a choleric-cheerful to a nearly normal $\left(\mathrm{e}_{2} \mathrm{Cc} \times \mathrm{E}_{2} \mathrm{C}_{2}\right)$ and of a nearly normal to a choleric-melancholic (manic-depressive) are next in order. 
In groups 3 and 4 the mating nervous-melancholic by calm-phlegmatic is the commonest, and nervous-phlegmatic by calm-melancholic and nervous-cheerful by calm-phlegmatic come next. Certain expected combinations, such as both parents calm-melancholic, do not occur. In group 5 the mating nervous-phlegmatic by calm-phlegmatic is much more frequent than expected.

TABLE E.-A comparison of the actual frequency of various matings with expected frequency on the assumption of mating at random.

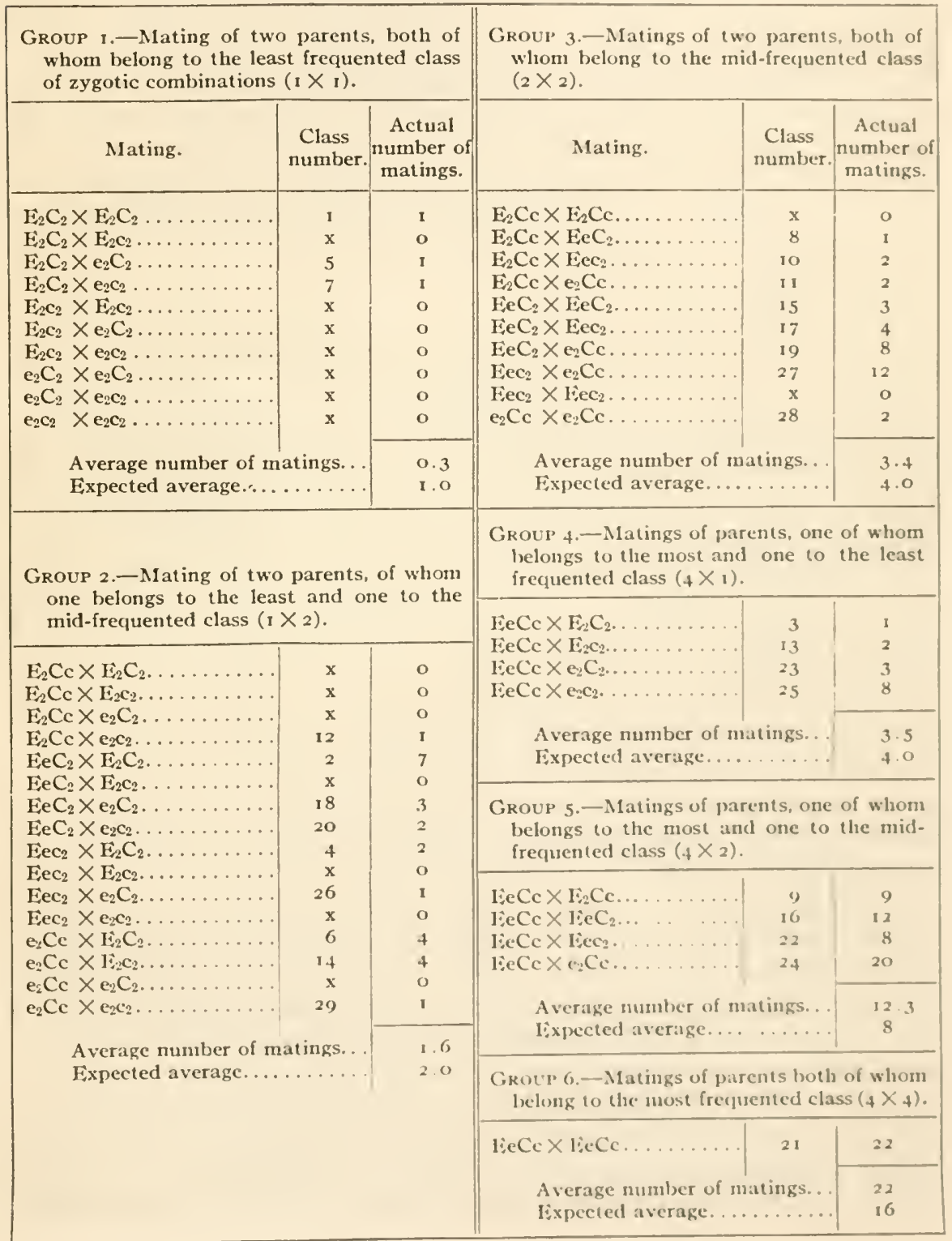


Summarizing, we find the following 7 matings whose frequency is much greater than expectancy;

$\begin{array}{lll}\mathrm{EeC}_{2} \times \mathrm{E}_{2} \mathrm{C}_{2} . & \mathrm{Eec}_{2} \times \mathrm{e}_{2} \mathrm{Cc} . & \mathrm{EeCc} \times \mathrm{e}_{2} \mathrm{c}_{2} . \\ \mathrm{e}_{2} \mathrm{Cc} \times \mathrm{E}_{2} \mathrm{C}_{2} . & \mathrm{EcC}_{2} \times \mathrm{e}_{2} \mathrm{Cc} . & \mathrm{EeCc} \times \mathrm{e}_{2} \mathrm{Cc} . \\ \mathrm{e}_{2} \mathrm{Cc} \times \mathrm{E}_{2} \mathrm{c}_{2} . & & \end{array}$

It will be observed that in none of these matings are the zygotic formulæ of both parents the same; in 6 cases the choleric or nervous temperament is mated with the absence of excitability; likewise, though melancholics marry, they have not (in this table) married melancholics. Also table E shows no case whatever of the mating of two melancholics, and only one mating, out of the 146 , of two cholerics. In table $\mathrm{E}$ no case occurs of the marriage of two nervous-melancholics nor of two choleric-phlegmatics (though they are common in the population as a whole). In general the table supports strongly the conclusion that there is a marriage selection against similar temperaments and a preference in mating for those of more or less markedly dissimilar temperaments.

\section{SUICIDE IN RELATION TO TEMPERAMENT.}

\section{INTRODUCTION.}

To the average man in normal health and with emotions undisturbed his own life is the most precious possession, to be protected at all hazards. The strong instinct of self-preservation has its clear biological value when found in normal persons who have not passed the reproductive period, since it tends to keep them alive until the next generation has been produced. And if it lingers for some years after the climacteric the fact finds its justification in the utility to the race of the knowledge and experience of older persons. On the other hand, it is clear that under certain conditions a strong love of life is a perversion. It is clearly such in those who are infirm with advanced age; and, indeed, it is not commonly found with such. The strong love of life is, in a degree, a perversion when associated with an incurable and painful disease, although there is a slight biological justification for this association dependent on the fact that there is hardly a disease, even tuberculosis and cancer and paresis, but that may in certain strains and under certain conditions in the prime of life heal itself. From one point of view the love of life in any young person who carries the determiners for an antisocial trait in his soma or his germ-cells is a perversion, for if it were absent the strain would be brought to an end, perhaps before the reproductive period, and the race would be purified. But, first, social ideals change so rapidly that nature has not, as it were, had time to make the adjustment; and secondly, it would be difficult always to say (and it is difficult for "Nature" always to determine) just what strains should be ended by this method. 
Despite obvious difficulties in the situation, we find a natural loss of the instinct of self-preservation under certain conditions where it nay be regarded as biologically fortunate and under others where it is less clearly so. Weakening of the instinct of life is shown, first, as stated, by many old persons, especially if infirm, and second, by persons in the prime of life who suffer great physical pain, as sometimes in cancer. In proportion to the number living, according to Prussian statistics, the frequency of suicides is relatively great after to years of age, and steadily increases to over 80 years.

Two classes remain for consideration, and these include the vast majority of suicides. Although there is a widespread view that suicides occur chiefly, if not wholly, in a depressed state, such is not at all the case; and, indeed, we must recognize that hyperkinctic suicides are quite as common as, if not more frequent than, the hypokinetic. We may consider these two classes separately.

\section{SUICIDES IN HYPERKINETICS.}

As an example of this type I may take a case which I had an opportunity to interview at Kings Park State Hospital, Dr. W. A. Macy, superintendent. The patient was introduced to me as showing the Korssakow syndrome; he was a German of a hyperkinetic type; he spoke brusquely and rapidly. He admitted that when he drank he threatened his wife. On one occasion, in the basement of one of the hospital buildings, an associate taunted him with being in for life; he cried, "Better dead!" and rushed head-on to the stone wall, but recovered from the impact. He admitted no depression, nor had he planned the suicide in the least degree.

Another case of hyperkinetic suicide is quoted from the records of the Eugenics Record Office. A man (13:314:III-34), born I 833, was as a youth very studious and ambitious to specialize in languages in order to teach them in college; his father, however, could not afford this, but offered to advance him in the law; but the boy was stubborn, and later entered the army toward the close of the war. In is65, lie was admitted to a State hospital; was noisy and destructive, and would not wear clothing. After ro years he was transferred to another hospital, where he had periods of excitement alternating with periods of tranquillity. During the former he would roar like a bull, stating that he was the "Asylum bull," was noisy, abusive, and obscene in language. When quiet would spend most of his time in his room. reading or writing; his language in the ward was most obscene. He was inclined to be quarrelsome at times and always nutidy in his appearance; he refused to wear shoes or stockings. In IS8, he connplained of the consequences of masturbation. Had bizarre delusions in I886; suffered keenly from them and begged the physician to giv'c him poison to put him out of his miscry: felt the authorities meant to 
chain him up and burn him, etc. April 1889 he was found dead in his room, having cut his throat with a table knife which the attendant failed to miss from the table the evening before. (Diagnosis: recurrent mania.)

Another Kings Park case is that of C. M., female, who has always been nervous and laughed easily. At 19 she began to lead an irregular sexual life. At 23 she married and became confined with child in July 1907. A few days later she became restless, excited, fearful, and tried to climb out of the window. Placed in a State hospital, she expressed remorse and anxiety. Later she grew excited, jumped out of bed, tried to escape by the window; said she felt like tearing herself to pieces. In March 1913 was actively disturbed, noisy, restless, assaultative, hallucinated, and in July apparently attempted suicide by strangling herself.

Another patient, C. M., male, about 17 years old, on December 22 made vicious assaults, kicked, growled, shouted, and on the $24^{\text {th }}$ attempted to strangle himself with a sheet. On other occasions when he was disturbed, excited, assaultive, he showed suicidal tendencies. And, again, a woman of 32 , always nervous and excitable, in a particularly disturbed period impulsively smashed windows and attacked those about her; said she heard voices telling her to kill herself; and on one occasion attempted to strangle herself with a part of her skirt.

Hammond (1883, p. 538) cites the case of a middle-aged man who rather suddenly developed hyperkinetic periods with quieter intervals. In one of these periods he attempted to cut his throat. The suicidal attempts of many alcoholics are of this type. And of this type is the propositus in our history 3. One December she became noisy and talked loudly, accused her mother-in-law of poisoning the baby, and threw herself out of the window. In our history No. I, the mother's brother, having been reproached by his sister, said he wouldn't stand that, threatened to kill himself, and took some "Rough on rats" and died at the age of 19 years. In these cases, apparently, concomitantly with the rising hyperkinetic condition, there is a complete loss of inhibitions and the instinct of self-preservation is thereby rendered impotent. The strong emotion induces vigorous action and as the machine is now running quite wild, it frequently destroys itself.

Here belong the impulsive suicides that seem to have no sort of motive.

Thus (family 4) the father's father's father at 70 withdrew his money from the bank, tied it in a bag, threw it into the pond, and jumped in after it, determined to drown himself. He was rescued. Nine years later he was seen to leave his plow and run toward the barn, where lis body was later found hanging from a rafter. In family i i, the patient complains of a certain round of thoughts going through his mind over and over again. The last evening he spent with his fiancée he seemed 
normal and happy; however, he did not return to his home, but hung himself in the wood, some distance from his mother's house. A sister of this man gives us a good idea of these impulsions to suicide, which she, too, has often experienced. After her husband's death she struggled constantly with suicidal thoughts. She is not subject to depressions.

A man in Kings Park Hospital (9472), while working as usual, suddenly grasped a pot of white paint and drank several ounces of it. He said voices told him to kill himself.

Needham (1872) has recorded the following case: In September I 858 a lady who was admitted into the York Lunatic Hospital at her own request, had the following history: Born in Italy, she early displayed excellent abilities and a lively and volatile disposition. Her education was carefully attended to, and she made rapid progress in her studies. At the age of 28 she was attacked by what was called brain fever, which left her, after an illness of some duration, with considerable mental irritability. She still, however, persevered with her duties, which were scholastic, and acted as governess in several families of distinction. This continued until she was about 43 years of age, when, her health having become somewhat inpaired, she was suddenly seized with the impulse, at sight of a razor or knife, to commit suicide or murder. She struggled against this feeling strenuously, and in the course of a few weeks it disappeared completely, and did not recur for more than 5 years. When it did recur she came voluntarily to the asylum and begged to be admitted. She was laboring under great mental distress lest her admission should be refused, and she expressed her decided conviction that she had reached the end of her self-control, and must give way to the impulse if she were not taken care of at once. She was apparently perfectly free from delusion, and conversed rationally and cleverly upon general subjects, manifesting, indeed, remarkable shrewdness and knowledge of the world. She was received into the asylum, and within a few weeks the impulse disappeared. A few weeks later an impulse to strangle herself appeared, but this, too, disappeared, and after a residence in the asylum of over 4 months she was discharged quite well. About 4 years later she once more presented herself at the asylum for admission, and was then found to be exactly as she had been when previously admitted. On this occasion she stayed in the asylum for 7 or 8 months, but recovered completely, and was discharged a second time. "The peculiar feature of this case," says Needham, "was that, from first to last, under careful daily observation, there was never the smallest trace of delusion or any other evidence of mental derangement than that which was afforded by the very decided suicidal impulse. The patient, on the contrary, was sensible, clever, and well-conducted."

Strahan (I893, p. 124) recorded a case very similar to the foregoing under his care for a time. In this case the patient, a married woman, 
felt impelled to murder her only child or herself. She told her husband of the impulse, and begged him to have her sent to an asylum "before something terrible would happen." One night her husband woke up and found his wife making a noise in the darkness by fumbling in a drawer which contained knives, spoons, etc. She was then, at her own request, and by the advice of her medical attendant, sent to an asylum; from which, after a residence of 6 months, she was discharged, improved, to the care of her friends.

In these cases a vivid idea, perhaps frequently if not usually, of the nature of an hallucination appears, and, in the absence of inhibitions, such a presentation is reacted to, again without reference to the instinct of self-preservation; for this instinct is chiefly an inhibitory instinct, and it is, by hypothesis, not operative. If the impulsive idea and the condition of feeble inhibition coincide in time self-destruction will follow, as in the propositus of No. I I, but if the idea is presented while inhibitions are active, as in his sister, suicide will not actually occur.

In this same group belong certain, if not most, cases of threats of suicide. The strong emotion is present; it is accompanied by violent action, emphatic language is used, furniture is perhaps destroyed, and the pati nt threatens to take the life of various convenient persons, including his own-as the extremest motor representation of his emotion-but, actually, the inhibitions are usually too strong and the homicide and suicide exist only as threats. In family history No. I 2 the propositus illustrates this pretty well. She was a continual talker; "talked all from her nerves;" became, under a certain stress, violent, restless, and noisy; developed delusions and hallucinations; threatened suicide, but never made the attempt.

In some cases it is less in anger or great excitement than in a condition of extreme vanity or amour propre which has been wounded by some slight that the threat is made and sometimes carried out. A physical attack may be fully reacted to by a show of force; but an injury to one's pride is to be repaired by forcing an apology from the insultor, and as this is not practicable directly for the young or subordinate person, the instinct is to do something that will make the other regret his insult, and the worse that thing the better. Suicide in consequence of the insult readily occurs to one as the limit, and the feeble inhibition interposes no sufficient obstacle to carrying out the suggestion. Here seem to belong the suicides of adolescence. The immediate "cause" is often given as "fear" of an impending punishment (properly the idea of putting the punisher in the wrong); disappointments in love (to put the rejector in the wrong); low school-report or failure to be promoted, and so on. Insult, blame, shame, reclamation directed toward the patient are once and for all wiped out or fully avoided by his suicide and the tables are turned on the offender or threatened offender, who is filled with regret, remorse, and self-accusation. Ado- 
lescence is apt to be a time of weakened inhibitions, and so suicides occur among school-children in great numbers. Thus Eulenberg (1914, p. 4) states that in Prussia the suicide-rate for persons under 20 years is, per 100,000 persons of the corresponding agres, from 6.6 to 8.6 in different years. Actually in Prussia, in 1905, 603 persons under 20 (403 male and 200 female) committed suicide. The large number appals us and we seek to secure its reduction, and yet the eliminated individuals are a highly selected and not the most desirable part of the population; they are selected on the basis of feeble inhibition.

\section{SUICIDES IN HYPOKINETICS.}

Suicides occur in these over-inhibited individuals as truly, though apparently not as frequently, as in the sub-inhibited. The mental anguish of the feeling of insufficiency and unworthiness secks relief, and the idea of death as a sure way out and the only way out is an alluring one. Here belong many cases of suicides accompanying arteriosclerotic depression (Gaupp, 1910, p. 23).

Examples of such suicides appear in the records of every hospital. I cite some from the Kings Park records. No. 6837 I, born I859, married happily, but was childless. July 1910 depression began; "she had crying spells daily and felt that nobody understood her case or cared for her." Admitted to the hospital the same month, she was depressed and moody; worried a great deal and did not sleep well $* * *_{*}^{*}$; asked her husband not to leave her alone, as she might harm hersclf; at times she showed considerable agitation. Remored 9 months later to a private sanitarium, she obtained a rope, climbed to the top of a fence surrounding the grounds, threw one end of the rope over a treelimb, fastened the other end to her neck, and then stepped off. This case well illustrates the deliberateness and certainty often shown in suicides of the depressed as opposed to the common (but not universal) precipitousness of the attempts of the liyperkinetic, which are frequently only shallow threats.

A patient at the hospital, an Irish girl, had been admitted 6 months before my interview. She stated that she had been unfaithful to her husband, who was a good and forgiving man, but she had sinned at a time when "things were dark to her" and she had no clear insight, and some days after that, on attending mass, she heard words spoken by the priest which deepened her depression; she was overwhelmed with remorse, and on her return home she went into the bath-room and turned on the gas, but was found before life was extinct. She continued to show marked depression up to the time of the interview, but had not been suicidal while at the hospital.

Our family histories give many instances of suicidal tendencies during depression, but often lack details. In family A (34:77) the propositus is easily discouraged, gets very much depressed, thinks no one 
cares whether she lives or dies, and, on one occasion, she had to be watched all night lest she take her life.

In family B (13:39) the propositus had an unfortunate love affair, worried over her two insane sibs, lost sleep, and became depressed. She made one attempt on her life and threatened another. One day she wandered away from home and was found lying in the snow trying to freeze; she was sent to a hospital and seemed greatly depressed.

In family I3 (4I:25) we have more than one case of suicide connected with depression. A successful man about 35 years old, a millionaire whose business was prospering, whose family affairs were devoid of difficulties, and who had no physical complaint, became depressed for days at a time. Finally he tried to take his life by hanging, but was found in time and was thereafter kept under constant watch. His father had also attempted suicide. A brother of this father, a leader in every good town movement, when past middle age became sad at times with no apparent cause and would remain in a depressed, quiet state for days at a time. Though carefully watched, he escaped one day and, lying face downward in a pool of water, drowned himself. Such histories are very common among men of past middle age suffering from melancholia.

The cases cited in the preceding paragraph are instructive, since they illustrate the condition that is frequently found of alternating hyperactivity and depression in the same individual at different times in his life. It is, indeed, conceivable that the same individual should at one time attempt suicide while in a hyperkinetic state, and later, in a depressed state, actually kill himself. But the suicide occurs in one state or the other, or in an hysterical, impulsive state that is allied to the hyperkinetic.

\section{THE INHERITANCE OF THESE TWO TYPES OF SUICIDES.}

We have just seen that usually suicides occur in particular states and probably only in such, either in an impulsive or hyperkinetic state or, on the other hand, in a depressed state. The state permits the suicide, but does not absolutely control it. In some families, to be sure, like No. 13 (4I:25), it seems as though a specific tendency to suicide is inherited. However, since it is impossible to consider as inheritable units all the different shades of success or failure of suicidal attempts, we shall do best, I think, to consider the inheritance of the states themselves in which the impulses occur.

Inheritance of the Thandency to Commit Sutcide while in the Hypirkinetic State.

An examination of 40 histories of families in which the prevailing mood is, for most persons in the family, one of hyperkinesis, shows that the hyperkinetic disposition rarely skips a generation. It can not infrequently be traced back through three generations, and this is about as far as the memory of man extends. In the case of family I I (I3:272) 
we have a girl who tried to drink carbolic acid; her father was suicidal and homicidal; her father's father is less well known, he was unsuccessful in business, and his father committed suicide.

In family $\mathrm{C}(7: 376)$ a young man who is hyperkinetic kills himself by inhaling gas; his mother was queer, absent-minded, and, at 60 , wanted to starve herself to death; of the mother's father we know only that he was "insane." In family D (40:734) a woman, who, indeed, has short spells of depression at the monthly period but who is markedly hysterical, gets restless, and has swallowed carbolic acid, set fire to her clothing, jumped overboard, etc., always unsuccessfully and obviously in a shallow fashion. Her mother was also emotional and at the age of 7 I was so excitable she had to be locked up. 'The mother's father, in turn, at 5 I attempted suicide by drowning.

Out of the 40 families, in 18 cases one of the parents of a suicide actually committed suicide. There is no clear case where neither parent was not excitable, with the possible exception of family 19 (I I: I30), where the mother of the hysterical and suicidal daughter is said to be "now suffering rheumatism and peevish and melancholy." In this case the mother's fraternity is full of hyperkinesis and suicide; and the mother's father committed suicide by lianging.

'Thus we see that in suicides that occur in the hyperkinetic state the state can be traced back through two or more generations without a break and very frequently also the tendency to suicide (probably, although naturally rarely demonstrably) in the same state.

This fact was remarked upon three-quarters of a century ago by Cazauvieilh (I840, p. I6), as quoted by Lucas (I850, p. 780). The reference is as follows: "la transmission séminale du suicide est d'autant plus á craindre, que les ascendants sont devenus aliénés, ou ont été partés à la mort voluntaire, sans motif appréciable, ou pour une cause légère ou imaginaire;" $i$. $e$., suicide is the more apt to be hereditary as the suicide of the ancestors (ascendants) is of the hysterical or hyperkinetic type. Naturally, dominant inheritance is more easily recognized as inheritance than the recessive type. Moreau de 'Tours (1906) states that evidence of direct heredity (i.e., without skipping of generations) of the suicidal impulse is too clear to be doubted for an instant, and he cites the case of a young girl of 15 years who is a prey to dark ideas and whose father and grandfather both committed suicide.

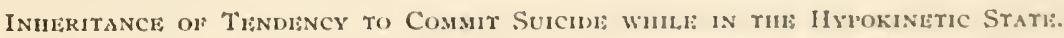

The inheritance of the tendency to commit suicide is less clear in the hypokinetic class of cases, because, from the nature of the cases, less easy to trace. But the suicidal tendency certainly recurs in the hypokinetics, as well as the hyper-hypokinetics and in the manic-depressives. Suicide following ateriosclerotic depression probably tends to run in families, as the arteriosclerotic basis is well known to do. 


\section{THE SPECIFICITY OF THE SUICIDAL IMPULSE.}

We have seen that "suicide" is not inherited, but only a tendency to an impulsion that leads to suicide; and we find that suicides arise out of two quite different soils. It might be concluded that there is nothing specific in the impulsions to suicide. It is, on the other hand, conceivable that, though only a general vague tendency to suicide is inherited, yet, when suicide occurs, it may not always be due to a diffuse impulsion to destruction, using the first means at hand, but it may be, in some cases, an impulse to do a specific act-to throw oneself into the water, or out of a window, or to cut one's throat, or to hang oneself. Indeed, there is no a priori reason for thinking that an impulsion to throw oneself out of the window is more closely related to the desire and purpose to hang oneself than it is to no impulsion at all.

The impulse is, indeed, quite distinct from the act. Only a small proportion of those who have the impulse to throw themselves from a height actually do so. Most persons inhibit the impulse; it is the feebly inhibited who give way to it. A fine insight into the nature of a suicidal impulse is given by a woman (45: I I5) whose brother suddenly hanged himself without any assignable cause, but in consequence of a long-standing idea of suicide. His sister, who has long been subject to impulsions toward suicide and homicide, after her husband's death "struggled constantly with suicidal thoughts. It seemed to her that she could hear the river calling to her to come, and she could imagine herself running gladly out into the water and lying down in its arms. The joy of the thought was so intense that it was almost like an ecstasy, and it was all that she could do to keep from answering the river's call." This lady is naturally of a happy, cheerful disposition and not subject to depressions. There is, doubtless, here a sexual longing mixed up with a self-destructive impulse like that shown by other members of her family. Hammond ( 1883, p. 447) has evidently cases of this sort in mind when he says:

"In some cases of emotional morbid impulse to suicide, the contemplation of the act is attended with feelings of pleasure. A man kills himself because he wishes to do so, and because of the satisfaction to be derived from gratifying his impulse. His intellect is not necessarily deranged; he acts with a full knowledge of what he is doing; and, if the circumstances require it, he employs the most systematic and recondite stratagems in order to accomplish his purpose. He is neither governed by delusions nor by logical reasons. He is simply actuated by a passion which it is pleasant for him to gratify."

Many writers have been struck by the fact that several suicides of a family often use the same means and often at about the same age. One of the most renarkable instances is given by Hammond (I883, p. 79) as having occurred in his own experience.

"A gentleman well to do in the world, but with a slight hereditary tendency to insanity, killed limself, in the thirty-fifth year of his age, by cutting his 
throat while in a warm bath. No cause could be assigned for the atct. He had two sons and a daughter, all under age at the time of his dcath. "The family separated, the daughter marrying. On arriving at the age of 35 the eldest son cut his throat while in a warm bath, but was rescued ere life was extinct. At about the same age the second son succeeded in killing himscif in the same way. 'The daughter, in her thirty-fourth year, was found dear? in a bath-tub with her throat cut. Her son, at the age of $2 \pi$, attempted to kill himself by cutting his throat while in a batlı at his hotcl in Paris, but dicl not succeed. Subsequently, at the age of 30, he made a similar unsuccessful attempt, but was again saved. A year afterward he was found in lis bath by his servant, with his throat cut from ear to ear."

Our own histories show, in some families, a tendency to self-destruction by one and the same method. 'Thus in No. I3 (41:17) the propositus, his brother, sister, two father's brother's sons, and a father's brother attempted suicide by hanging and succeeded in all but 2 of the 6 instances. It niay be added that, in the same family, are I case of suicide by drowning, 3 unsuccessful attempts by other methods, and 2 suicides of which the method is not described, or 12 in all.

In family $22(6: 328)$ brother and father cut their throats with razors and a sister had impulsions to do the same. In family 23 (14:169) a woman drank carbolic acid and her son did the same at the same age. In family $60(4 \mathrm{I}: 59)$ the propositus suicided by shooting, his brother attempted suicide by shooting (but failed, was shut up in a hospital, and there killed himself by drinking poison); the mother's father committed suicide by shooting. In family 49 (12:22S) the propositus cut his throat, and so did a brother and the mother's brother. Among the father's sibs death occurred by lianging and drowning. In family 7 I $(44: 435)$ a brother had an impulse to go into the water and a brother's son threatened to drown himself or to hang himself. 'Three others in this family had suicidal tendencies not fully described.

The foregoing cases of a similar form of suicide in several members of one family are striking; but it must not be forgotten that, first, one and the same person may, at different times, slow an impulsion to different forms of suicide; and, second, that it is more common to find different members of one family using different methods of suicide than to find all employing the same method; and, third, in one case we have a father's father's son and a father's mother's brother (thus, unrelated) both committing suicide by jumping ont of the window. As to the first, in a family of our records (40:730) the propositus at different times took carbolic acid, set her clothes on fire, jumped ont of the window, and tried to choke herself with a breaderust, clearly showing the alsence of a specific impulse in her case. As an illustration of the second point we have fanily i I $(13: 273)$, where the propositus tried to drink carbolic acid, the lather intended to kill hinself with a revolver, and the father's father attempted to drown himself and later actually hung himself; thus in the three generations four fuite different methods are employed. I think we must admit that while in cer- 
tain families there is an inherited impulse to a particular suicidal act, in other cases the impulse is less specific. Nevertheless, it is to be noted that the common forms of suicide are rather few, namely, "drowning, hanging, firearms, wounds, poisoning, falls from a height, and asphyxia" (Morselli, I882, p. 314), and, therefore, it would not be strange to find 2 or 3 members of a family by chance choosing the same mode (as two unrelated members have chosen it). Also a knowledge of the method of suicide in one member may act suggestively upon another. Still, we can not overlook the fact that 6 hangings in one family in the direct line, 3 cases of impulsions to cut the throat in each of two other families, a case of mother and son who drink carbolic acid at the same age a quarter of a century apart in time, and the case given by Hammond (described above) can not be chance merely; and a present suicide is not influenced by the conscious memory of one that occurred a generation or two ago. It is probable either that the choice is determined by the resurrection of a repressed memory or that there is an hereditary bias toward one form of self-destruction. Thus, hyperkinetics are more apt to use any means which is near at hand, and which is often inadequate, such as jumping out of the window or choking with a string; while hypokinetics use methods which require greater deliberation and are usually effective, such as shooting and hanging.

\section{REMARKS ON THE CATEGORIES OF FUNCTIONAL INSANITY.}

As we have seen, psychiatrists are prone to speak of mental troubles not only of the "organic" type but also of the functional, as diseases. And, though there have not been wanting those who have warned against this view, it seems to be current practice to so regard them. We note the great importance laid in the staff meetings of State hospitals upon diagnosis. Yet a study of hospital records shows, first, that a large proportion of patients do not fit either of the main functional types; so that the diagnosis is given, for instance, as dementia precox with melancholia. On one occasion when I was invited to attend a staff meeting of a State hospital, not one of the 6 cases of functional insanity that was presented clearly belonged to either of the two types of functional insanity. Again, it is not uncommon to find that a patient who is admitted a second or third time to a State hospital has received a different diagnosis each time. Now, where there is so much doubt as to how the "diseases" are to be differentiated, it is fair to doubt if they are entities. Indeed the conclusion is forced upon one that we are dealing with complexes of behavior, with syndromes.

Not only are the functional insanities not disease entities, but it is fair to doubt if the term "disease" is properly applied to them. Disordered, incompatible with the highest requirements of organized 
society, they doubtless are; but those requirements are, after all, rather narrow and rigid, and it would be strange if, amid the vast range of human characteristics, many combinations did not occur that are far from ideal. If a person shows periodic excitement but has intelligence enough to put himself during the outburst where he will do no harm, society can easily tolerate him; but another who has similar outbursts and is not intelligent enough to segregate himself or work off the excitement by other methods, but who assaults, breaks furniture, and yells, has to be confined. It is doubtful if the latter is more truly diseased than the former; but his complex of traits is less social. Similarly, the classical dementia precox in its earlier stages shows a complex of traits that are constitutional, and that separably are not unknown in some degree among persons who pass for normal, but together are quite incompatible with efficiency and a proper standing in society. Studies in inheritance of the elements of intelligence, or resistance to mental stress and of disposition, seem to point clearly to the conclusion that the functionally insane are mosaics of chance, accidental associations of socially undesirable, hereditary traits. As a corollary it seems probable that the Kraepelinian or any other classification of the functionally insane is rather harmful than otherwise, since it distracts attention from the principal points, such as periodicity, temperament, inhibition, the destruction of neurones in the cerebrum, and the specific control of behavior by internal secretions. When we analyze behavior, when we seck to find upon what neural or visceral differences each elementary trait of behavior depends, then we may make progress toward a knowledge of real causes and toward such improvement of conditions by physiological-chemical means, or others, as may be possible.

\section{THE HYPERKINETICS AND THE HYPOKINETICS IN THE POPULATION-THE ROMANTIC AND THE CLASSIC TYPES.}

We have seen that at one extreme of the population are to be found overactive, jolly persons; at the opposite extreme the exceptionally quict and sad. Of course between these extremes lie the vast majority of people who are more or less intermediate or mixed, but many of them show a clear inclination toward the one or the other condition. These two types have been recognized before. One of the most interesting treatments of them as they occur among geniuses is that of Ostwald (1909) in "Grosse Männer." He separates them into the romantics and the classics, and says they differ in the rapidity of their reactions. The classics are the slower, the romantics the swifter. And these types he correlates with the four temperaments of the older psychology, in that the sanguine and choleric are the quickly-reacting temperaments; the phelgmatic and melancholic the slowly-reacting temperaments; and of these the choleric and melancholic represent 
the extreme types. The romantics are characterized by precocity, the classics are more retarded in their development. The romantic men of science produce rapidly and much and require surroundings which afford them a stimulus. They are fill of ideas and readily impart them to others. They attract students and impart their enthusiasm to them. They become famous teachers, like Louis Agassiz in America. They have a wealth of ideas, plans, and problems with which their pupils are kept busy. They are of ready assistance to their pupils, being full of suggestions to help them in their difficulties. The classics, on the other hand, work better alone. They are of little use to any but their profoundest pupils, and they publish relatively little, but what they publish is philosophical and finished. Helmholtz was of this type. He was always a poor teacher, despite his vast knowledge, his extensive experience, and his creative genius; for he reacted not on the spot, but only after some time. If a student in his laboratory laid a question before him he promised to think over it, and gave his answer some days later and of ten so elaborately and fully wrought out that the pupil could see no relation of the reply to his problem. One thinks also of the great physician, Rowland, of Johns Hopkins University, who, when asked what he proposed to do with his students, said, "I shall neglect them." Such men of science thrive best in comparative isolation. These two types thus depicted among men of science are really to be found in the general population. In business, the bold, energetic, dashing promoter and the solid, conservative, thrifty merchant; in law, the emotional jury-lawyer and the learned judge; in medicine the skillful operator in difficult cases and the skilled diagnostician and consultant; in divinity, the magnetic evangelist and the profound theologian or exegetist; in war a dashing Sheridan and a solid, quiet Grant. The romantic and the classic type-the hyperkinetic and the hypokinetic, the radical and the conservative, the feebly-inhibited and the strongly-inhibited constitute a dualism that runs through our whole population; and this difference will, I predict, prove to be due to hereditary factors, even as proves to be the case in the manic-depressive syndrome.

Finally, it is interesting that the old popular nomenclature of temperaments-choleric, nervous, phlegmatic, melancholic-should prove so suitable to our case and to fall so in line with the findings of heredity. Owing to the circumstance that all behavior is colored by other factors than simple temperament, and that experience, no doubt, introduces modifications, all persons who fall into the same one of our 9 classes do not react in precisely the same way. For instance, some drink and others do not; some tend to run away and others to stay at home; some show violent temper, others have sick headaches, others are highly erotic, and so on. But, wending its way through the forest of hereditary factors in human behavior is the well-marked trail of the hereditary 
influence that makes for a greater or less display of emotional qualities in the individual. Just what we shall have an impulse to clo is determined by numerous factors; but the general nature of our reactions, whether violent or repressed - this is determined by the hereditary nature of our temperaments.

\section{SUMMARY.}

Problem.-What hereditary factors determine constitutional temperament and its expression in mood? What factors determine that one person shall be prevailingly elated, another depressed, and another still show, at different times, both of these conditions?

Definitions. - The condition of activity above the average is called "hyperkinesis;" that below the average is called "hypokinesis;" and each occurs in two grades. From the old psychology is borrowed the terminology of temperament-choleric, nervous, normal (calm and cheerful), phlegmatic, melancholic; and any one of these may be combined with any other.

Hypothesis.-The following hypothesis is proposed: There is in the germ-plasm a factor, $\mathrm{E}$, which induces the more or less periodic occurrence of an excited condition (or an exceptionally strong reactibility to exciting presentations); its absence, e, results in an absence of extreme excitability. (calmness). There are also a factor $\mathrm{C}$, which makes for normal cheerfulness of mood, and its absence, c, which permits a more or less periodic depression. Moreover, these factors behave as though in different chromosomes, so that they are inherited independently of each other and may occur in any combination.

The method is the study of the progeny of 146 matings of two persons who are fairly well described themselves and of whom the temperaments of the parents usually, and of certain of their children always, are known. To these parents are ascribed the most probable zygotic formulæ based on their behavior and the most probable gametic formulæ of their parents; then from the parental formulx is calculated (table B) the probable frequency of the temperaments in the offspring, and a comparison is made between the calculated and the observed frequencies (tables $\mathrm{C}$ and $\mathrm{D}$ ).

Results.-The hypothesis is supported by the following evidence:

(I) By the close relation between the actual and the calculated frequency of the various classes among the offspring of parents of known zygotic constitution (tables $\mathrm{C}$ and $\mathrm{D}$ ). The two series follow each other fairly closely, except for an excess of actual normals and ntearnormals, and an excess of manic-depressive offspring probably due to the fact that our material was selected to secure as large a proportion as possible of them (p. 89).

(2) By the fact that only 0.95 per cent of the offspring do not conform to hypothesis; that the lyypothesis works! Actually, of 133 off- 
spring of a manic parent, all are excitable except 6 "normals." When neither parent is excitable, none of the children are excitable; when neither parent shows depression the children rarely do; when one parent shows melancholia and the other carries no depression, none of the children suffer from melancholia (p. 90).

(3) None of the other three hypotheses that may be applied to the facts of family distribution of temperaments works nearly so satisfactorily as the hypothesis suggested (pp. 9I-92).

(4) In manic-depressive insanity the manic and the depressed tendencies are inherited differently. This corollary of "the hypothesis" serves to harmonize the different views as to the inheritance of functional insanity. Also, there is much evidence from the literature that this distinction has been dimly seen (pp. 95-99).

(5) The evidence of similarity of temperament of "identical twins" supports the view of the specific inheritableness of the type of temperament (pp. 100-105).

In marriage selection it is quite certain that unconscious temperament plays an important part. Thus the mated pair rarely have the same zygotic temperamental formula. Two choleric or nervous persons preferably do not marry each other. Two melancholics rarely intermarry. There is, in marriage, a selection against similar temperaments and a preference for those of more or less markedly dissimilar temperaments (pp. 106-108).

In suicides the same two types of the hyperkinetic and the hypokinetic can be distinguished (pp. 108-115).

A family tendency to suicide by the same method is evident; but it is uncertain whether this is due chiefly to subconscious suggestion or to an hereditary bias (pp. I i 6-i i 8).

The functional insanities are regarded as syndromes whose elements are separately inheritable (pp. I 18-119).

Just what we shall do, in any situation, is determined by numerous factors; but the general nature of our reactions, whether violent or repressed-this is determined by the hereditary nature of our temperaments (pp. I 20-I $2 \mathrm{I}$ ).

The romantic and the classic types, the hyperkinetic and the hypokinetic, the radical and the conservative, the feebly-inhibited and the strongly-inhibited, constitute a dualism that runs through our whole population (p. I2O). 


\section{LITERATURE CITED.}

AlbRLCIT (Treptow a. Riga). 1912. Gleichartige und ungleichartige Vererbung des Geisteskrankheiten. Ztschr. f. d. ges. Neur. u. Psychiat. Orig., Bd. XI, Hft. 5. $540-580$.

BALL, B. 1884. De la folie gémellaire ou aliénation mentale chez les jumeaux. I,éncephale, IV, 385-400.

BAUME, I. C. 1863. Singulier cas de folie suicide chez deux frères jumeaux-coincidences bizarre. Ann. médico-psycholog. (4), 1, 312, 313.

BERzE, J. I909. Die manisch-depressive Familie H-. Monatschr. f. Psychiatrie u. Neurologie, Xxvi, 270-288.

Burrows, G. M. 1820. An Inquiry into Certain Iirrors relative to Insanity and their Consequences, Physical, Moral, and Civil. Isondon.

Cannon, W. B. 1915. Bodily Changes in Pain, Hunger, Ficar, and Rage. An account of recent researches into the function of emotional excitement. New York, Appleton, $311 \mathrm{pp}$.

Cazauvieil.h, J. B. 1840 . Du suicide.

Chatelain, M. I883. Folie à deux. Rev. méd. de la Suisse romande, IV, 348.

Cockayne, E. A. 1911. Disease in Homogeneous Twins. Brit. Jour. of Children's Diseases, viII, 487-491.

Cullère, A. 1901. Deux nouveaux cas de folie gémellaire. Archives de neurologie (2), XI, 97-114.

DAVENPORT, C. B. 1915. The Feebly Inhibited. III. Inheritance of Temperament; with special reference to Twins and Suicides. Proc. Nat. Acad. Sci., I, 456-459. Aug.

Dawson, W. R. I900. The Rôle of the Blood Supply in Mental Pleasure and Pain. Dublin Journ. of Med. Sci., cIX, 126-149.

EULENBERG, A. 1914. Kinder- und Jugendselbstmord. Sammlung zwangloser Abh. a.d. Gebiete d. Nerven- u. Geisteskr., Bd. x, Hft. 6, 34 pp.

EUPHRat, H. 1886. Ueber das Zwillingsirrescin. Allg. Ztschr. f. Psychiatrie, XLiv, 197.

FFLINTOFF-Micki,e, A. 1883. Twins in Similar States of Imbecility. Jour. Mental Sci., $\operatorname{xxrx}, 400-401$.

Fields, ANnie. I898. Life and Letters of Harriet Beecher Stowe. London, Low, Marston, $406 \mathrm{pp}$.

GaLToN, F. 1883. "History of Twins," in Inquiries into Human Faculty and its Development. Reprinted in "Everyman's Library." London, Dent; New York, Dutton.

Gal,Ton, F. 1889. Natural Inheritance. New York, Macmillan, 259 pp.

GaUPP, R. 1910. Ueber den Selbstmord. München, Gmelin., 32 pp.

Geofrroy, A. E. I $86 \mathrm{I}$. De la folic à double forme. Thèse de Paris, 103 pp. (cited by Hammond, 1883, p. 57 I).

GrL, C. 1883. Twins Suffering from Mania. Journ. of Mental Sci., xxvir, 540-544.

Hammond, W. A. I883. A Treatise on Insanity in its Medical Rclations. New York, Appleton, $767 \mathrm{pp}$.

HASSE, J. P. 1887. [Insanity in twins.] Allg. Ztschr. für Psychiatric, Xliv, 489.

Jol, Y, P. 1913. Die Heredität der Psychosen. Arch. f. Psych. u. Nervenkrankheiten, Bd. $52,283 \mathrm{pp}$.

KRAEPELIN, E. I909. Psychiatrie, 8 Aufl., Leipzig, Barth, I Band, xiv +676 pp.

LucAs, P. 1847-50. Traité philosophique et physiologique de l'hérédité naturclle. Tome I, 625 pp. (I 847 ); Tome II, 935 pp). (I 850 ).

Moenbius, P. J. 1884. Ueber nervöse Familien. Allg. Ztschr. f. P'sychiatrie, xt, pp. $228-243$.

MOREAU, J. (de Tours). I859. La psychologie morbide dans ses rapports avec la philosophie de l'histoire, etc., Paris, Masson, xu1 +576 pp.

MOREAU DE TOURS. 1906. Du suicicle chez les enfants. Thèse pour le doctorate en médicine. Fàc. de méd. de Paris.

MORSELL.1, H. I882. Suicide: An Essay on Comparative Moral Statistics. Internat. Sci. Ser., xxxvi. New York, Appleton, $x i+388$ pp., 4 pls.

Nefedham, F. 1872. Homicidal Impulse. Journ. of Mental Sci., July, pp. 212-216.

Nitsche, P. 1910. Ueber chronisch-manische Zustände. Ally. Ztschr. f. Psyehiatrie, LXVII, 36-I33. 
Ostermayer, N. I 890 . Zur Lehre vom Zwillingsirresein. Arch. für Psychiatrie, xxiI, 88-III.

Ostwald, W. 1909. Grosse Männer. Leipzig, ix+424 pp.

Rosanoff, A. J., and FloRENCE J. ORR. 1911. A Study of Heredity of Insanity in the Light of the Mendelian Theory. Amer. Jour. of Insanity, LXVIII, 221-261. Also Eugenics Record Office Bull. No. 5 .

Rosenfeld, M. I9I3. Ueber die Beziehungen des manisch-depressiven Irreseins zu körperlichen Erkrankungen. Allg. Ztschr. f. Psych. u. psych.-gericht. Med., Lxx, 185-204.

RÜDIN, E. 1911. Einige Wege und Ziele der Familienforschung, mit Rücksicht auf die Psychiatrie. Ztschr. f. d. ges. Neurologie und Psychiatrie, vII, Hft. 5, pp. 487-585.

Savage, G. H. 1883. Twins Suffering from Similar Attacks of Melancholia. Journ. of Nerv. and Mental Disease, xxviIr, 539-540.

Scrï̈r, H. 1866. Beitrag zur Casuistik der Zwillingspsychosen (folie gémellaire) und des inducirten Irreseins (folie à deux). Charité-Annalen, XII, 42 1-446.

Smirh, P. 1912. Psychoses Occurring in Twins. New York Med. Journ., Xcvi, 12681272.

SoUThARD, E. E. 1914. The Association of Various Hyperkinetic Symptoms with Partial Lesions of the Optic Thalamus. Journ. Nerv. and Mental Dis., XLI, 6r 7-639.

StelzNer, H. 1906. Analyse von 200 Selbstmord-fällen nebst Beitrag zur Prognostik der mit Selbstmordgedanken verknupften Psychosen. Berlin, S. Karger, r 24 pp.

Strahan, S. A. K. 1893. Suicide and Insanity. London, 228 pp.

Stransky, E. 1911. Das manisch-depressive Irresein in Aschaffenburg. Handbuch der Psychiatrie, Spec. Teil., 6 Abth., Leipzig, Deuticke, 272 pp.

Tissor, F. 1909. Imbécillitè gémellaire. Arch. de Neurol. (6), II, pp. 8-12.

WENDT (Berlin). 1887. [Insanity in Twins.] All. Ztsch. f. Psychiatrie, XzIV, 488-489.

Wittermann, E. 1913. Psychiatrische Familienforschung. Ztschr. f.i. d. ges. Neurologie u. Psychiatrie, Bd. xx, Hft. 2, pp. $153-278$.

YERKES, R. M. I9I3. The Heredity of Savageness and Wildness in Rats. Jour. Animal Behavior, IIr, pp. 286-296, August. 


\section{APPENDIX.}

\section{PEDIGREE CHARTS OF THE 89 FAMILIES STUDIED; AND DESCRIPTIVE LEGENDS.}

\section{DESCRIPTION OF FIGURES.}

The figures are pedigree charts of the families studied. In these charts the earlier generations are placed above, the younger ones below. Square symbols represent males; circles females. Fraternities of full brothers and sisters are connected by a horizontal line lying above the symbols. The longer vertical lines connect parents with the fraternity of their offspring.

Most of the symbols are marked to indicate the probable zygotic constitution of their temperaments. $\quad N$ indicates normal temperament $\left(i . c ., e_{2} \mathrm{C}_{2}\right.$ ); $\mathrm{X}$ indicates lack of knowledge concerning temperament; d.inf., died in infancy; d. $y g$., died young; $A$, alcoholic; $E$, epileptic; $F$, feeble-minded; $I$, insane; $W$, wanderer. Underscoring implies that the individual was in an institution. The index ( of symbol implies that the exciting factor is simplex; a broad band, exciting factor duplex. A narrow black band in lower part of symbol means cheerful factor simplex; a broad black band, cheerful factor nulliplex, or entirely absent. Thus, a wholly black figure implies exciting factor duplex and cheerful factor nulliplex; or, the individual is a manic-depressive. The broken band implies the probability of a simplex cheerful factor without clear corresponding somatic manifestations.

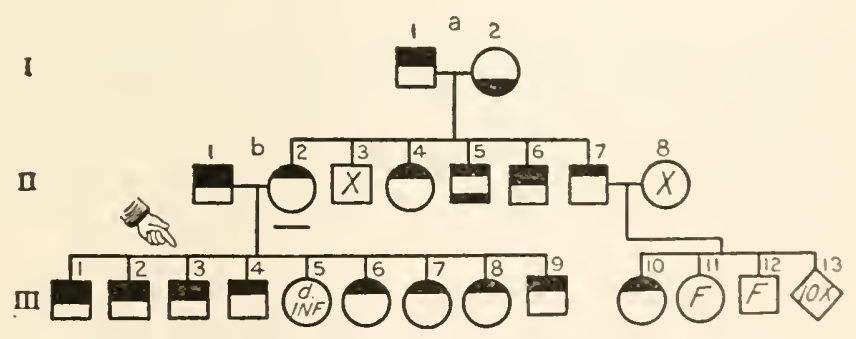

FIG. I.

Fioure I.-I-1, a great fighter; of ugly, disagreeable disposition. I-2, of a pleasant disposition and healthy, except for sick headaches. II-1, surly and disagreeable; was hypererotic and brutal to his wife and children. II-2, somewhat mentally defective; had an illegitinate child at 13, and convulsions with loss of consciousness from 17 years. At 50 was restless. excited, profane for a month; at 54 was dull, stupid, apathetic; lial periods when she would be noisy, excited, destructive, and abusive, alternating with periods of yuict, contentment, and cheerfulness. At 55 and 58 a period of depression is notet. II-3, a roamer. II-4. somewhat hot-tempered. II-5, emotional and morose. II-6, hecarne wild and rechless; reproached by his sister, he said that he would not stand that, took some "Romgh on IRats" and died at 19 years. II-7, garrulons and unreliable; near end of life he hat "blind șrells." when he recognized nobody. II-8, of fair reputation. III-1, has a swaggering : manner; ran away from home; was put in a reform seloool for rape. III-2, will and hot. tempered; profane and ugly toward his wife; takes whisky regularly to forget his business worries. III-3, jailed at 14 years for rape; hung limself. III - + , inclined to be disagreeable and distant; jealous of his wife and made false accusations. III-6. erotic, slovenly, lazy. III-7. epileptiform spelis; nervous and easily worked up. III-8, nervous; apparently" impossible for her to sit still. III-9, a braggart, bull-headed and stubluorn. III- 10, a prostitute. (28:1139.) 
Figure 2.-I-2, kindly. I-3, always peculiar; showed a strong religious trend; wandered of hunting. II-1, even-tempered, temperate, and patient with his wife. II-2, subject to attacks of mania, when she was violent and wandered from home; had hysteric spasms and despondent and religious attacks. III-1, is nervous, excitable, and rather peculiar; disappointed in love at 21 , he attempted to poison himself and threatened to kill his rival; is ugly after drinking heavily. III-2, had terror "spells" at night; naturally cheerful, but subject to depressions. III -3 , cordial and coöperating. III-4, quiet and kindly; nagged by his wife, he shot himself. III-6, full of fun. III-7, unsociable, excit-

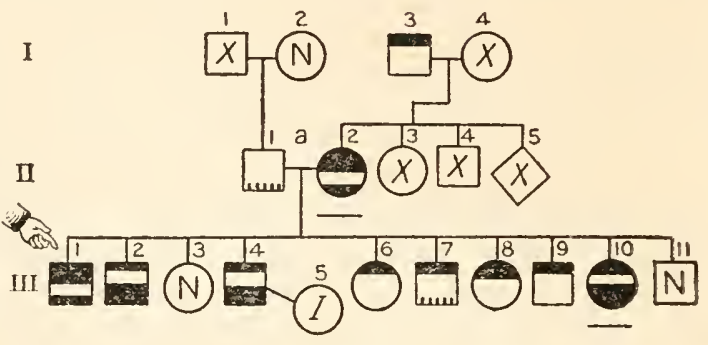

Fig. 2. able, shuns the opposite sex. III-8, became violently insane at 17 ; put broken glass in pie that was being baked for the family; recovered; naturally jolly and kind. III-9, goodnatured, generous, pleasant.

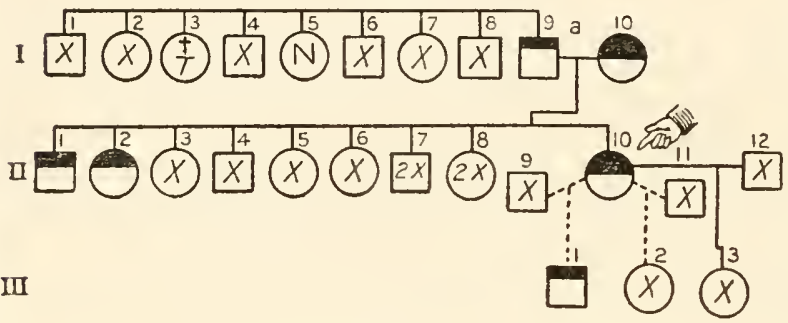

FIG. 3. III-ro, before birth of her first child had crying spells; before birth of the second imagined she was going to die; tried to commit suicide by poison and choking and throwing herself downstairs; had self-accusations, hallucinations of hearing; became despondent periodically; had ideas of reference and persecution at 25 . III-11, thrifty, sociable, and kindly. (45:160.)

FIgURE 3.-I-9, of good disposition, even-tempered and affectionate; in spells which he did not recall and which grew more frequent he would roar, scream, and struggle violently. I-10, rough and uncouth; easily excited, passionate; has fits of temper. II-1, nervous. II-2, has epileptic spells like her father, but more often. II-6, has monthly sick headaches, II-10, was $S x$; attempted to hang herself; flew into fits of temper; was slovenly, seclusive. indecent; at 32 had delusions of being talked about and of her baby being poisoned; became noisy and quarrelsome; threw herself out of the window. III-1, ugly, stubborn, and wayward. (V-9:15.)

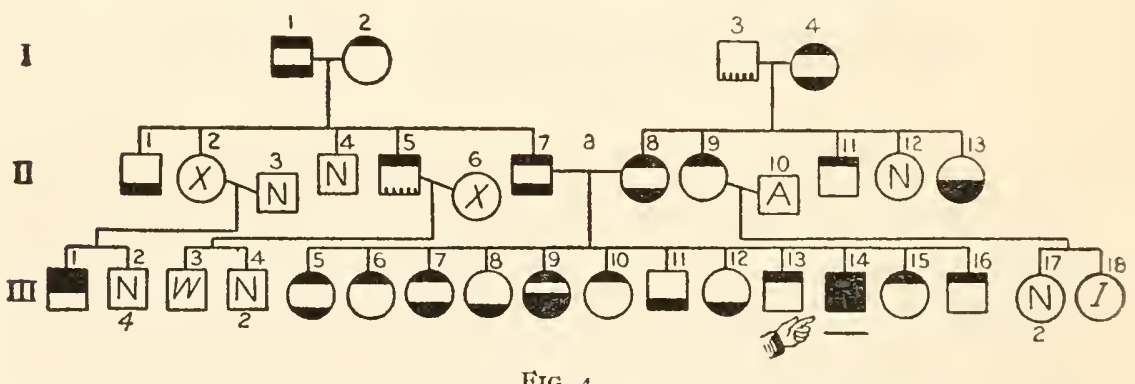

Fig. 4 .

FIGURE 4.-I-1, of a strong, roving disposition, but cheerful and pleasant; became very enotional and had delusions and haliucinations. I-2, energetic, cheery, sociable, with steady nerves. I-3, had fainting-spells. I-4, was intensely religious; was moody and very serious at times, then full of fun and cheerful; tlireatened suicide and to kill the family during the menopause; at 81 ran away. II -1 , had nervous fainting-spells. II -5 , jolly and talkative; had a tendency to wander. II-7, a good talker; nervous, rather excitable, and sensitive to noises. II-8, generous, very energetic, cheerful; had severe headaches. II-9, quick and hightempered. II-11, changes business and moves frequently from place to place. II-12, cheerful. II-I3, very nervous and irritable, has despondent and moody spells; wants to be social but is not. III-1, violent at times. III-3, very wild; has wanderlust. III-5, 
Figure: 4 -continued.

sociable and fond of entertaining; had nervous prostration after her hishand's death. III 6 . sociable and jolly. III -7 , sociable and jolly, but since the birth of a child is irrital,le and inclined to worry. III-8, quiet and even-tempered, but serious-minded and not sociable. IlI-9, lively, jolly, and sociable, but was depressed after her husband's death. III-10, nervous, excitable, and irritable; III-11, hyper-religious; shows wanderlust; goes on quarterly sprees; becomes reckless and afterwards remorseful. III-12, broods over her brother's insanity and cries without provocation. III-13, musical, lively, sociable, but unmanageable. III-1 4 , had violent spells of temper; was seclusive, bashful with girls, musical; had hallucinations and delusions and periods of excitement and depression. III-15, fond of entertaining. III-I6, lively and mischievous. III-I8, very musical; developed a religious mania and died insaue at 21 . (45:198).

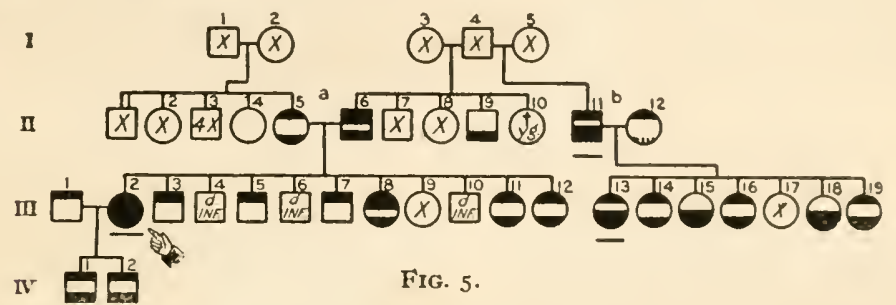

FIGURE 5.-I-I, 2, no history of mental trouble. II-5, over-active; not quick-tempered nor complaining, not demonstrative. II -6 , conceited, miserly, unreasonable, stubborn, hightempered, irritable, stern, strict, and hypochondriacal. II -7 , committed suicide by hanging. II-9, at 18 and 25 had a nervous breakdown. II-II, became depressed and melancholy; at times was irritable and assaultive; had ideas of reference; attempted suicide at 55 ; became very excited at 62. II-12, once took an axe to a collector. III-1, jolly, sociable, generous, but a moderate drinker. III-2, as a girl was cheerful, social but over-active, stubborn, and selfish. At the beginning of the menstrual period she was despondent, then excited and elated; had a depressed period at 35 and at 37 attempted suicide. III-3, jolly, talkative, and bright; was forced to marry a woman of ill repute whom he later divorced. III-5, "flighty," irresponsible, a spend thrift, quick-tempered; now in the army. III-7, sociable, affectionate, irritable, jealous, cheerful, eccentric. III-8, jolly, care-free, talkative, $S x$, quick-tempered. irritable, hypochondriacal. III-11, quick-tempered, care-free, fond of dress; a nagger and a complainer. III-12, stubborn, quick-tempered, and irritable at times. III-13, sociable, friendly, optimistic. Had a nervous depression at fo and became restless, moaned and talked. III-I 4, had "tics;" was a scolder and a worrier. III-15, had two attacks of nervous prostration; at about 30 was melancholy and cried. III-16, had spasms at pisbert $y$; was cheerful in disposition. III-18, melancholic. III-19, is upset by her hushand's sprees; is unreasonable. IV-I, very bright, but stubborn and sly. IV-2, enotional. (V-8: I.)

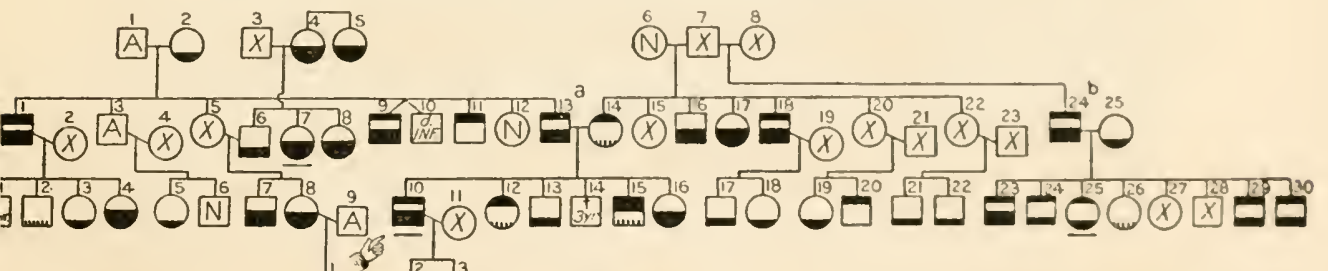

FIG. 6.

FrgURA 6.-I-2, a great worrier. I-4, had attacks of melancholia. I-5, melancholic. 1-7, a successful farmer. II-I, a worrier; would absent himself from home; became irritable, violent-tempered, and melancholy before his death. II-3, went on sprees and drank himself to death. II -4 , separated from her husbard. II-6, a worrier. 11-7, melancholic. II-8, melancholic. II-9, a great worker; clieerful but became restless and melancholy. II-II, lively and pleasant and hospitable. II-12, of a gentle, checrful, kindly dispusition. II-13, worried easily; troubles bothered him; was usually clicerful, jolly, hospitable, and kind. II-14, of a cheerful disposition. II -16 , of a worrying disposition. When cancer developed he became downhearted and hanged himself. 11-17, grieved herself to death when separated from her relatives. II -18 , of a jolly disposition; worricd for fear he would not be able to support himself and hanged himself. II-22, of a good disposition. I1-24, quiet and jovial; became melancholy and tried to choke himself. II -25, soher, sedate, serious-minded. III-2. temperate and of a good dispostion. III-3, a worrisone, dissatisfied nagger. III-4. had quiet spells; was inclancholy, brooded, and wept. III-5, worries easily. 11I-6, intelligent 
Figure 6-continued.

and pleasant. III -7 , of a quiet, cheerful disposition; has had two melancholy spells; brooded and was mute. III-8, became very depressed; now is quiet and reticent. III $\rightarrow$ IO, was jolly, cheerful, talkative, kind-hearted, but close; at times worried unduly; at 59 had ideas of reference and attempted suicide, but repented. III-II, nervous. III-I2, cheerful and optimistic. III-I3, temperatc, affable; had dizzy spells. III-I5, over-active, ambitious, over-worked. III-16, when jilted she seemed depressed, then appeared normal, and then hanged herself when 22 . III-17, a worrier. III-18, easily tired; a worrier. III-19, odd and at times mute; a worrier. III-20, bright and successful. III-2 I, became discouraged, drank to excess, but now moderately. III-22, became alcoholic after a heavy loss; now drinks moderately. III-23, irritable, quick-tempered, excitable; became melancholy and hallucinated. III-24, excitable, self-willed; had nervous prostration. III-25, bright, selfwilled, sensitive; had delusions and hallucinations at 68 . III-26, had no nervousness. III-29, full of fun and fight; drank by spells. III-30, of a good disposition and religious. IV -1 , had delusions as to age when 26; was unstable, emotlonal, hypochondriacal, and hypersexual. IV -3 , unambitious and dependent. (V-8:93.)

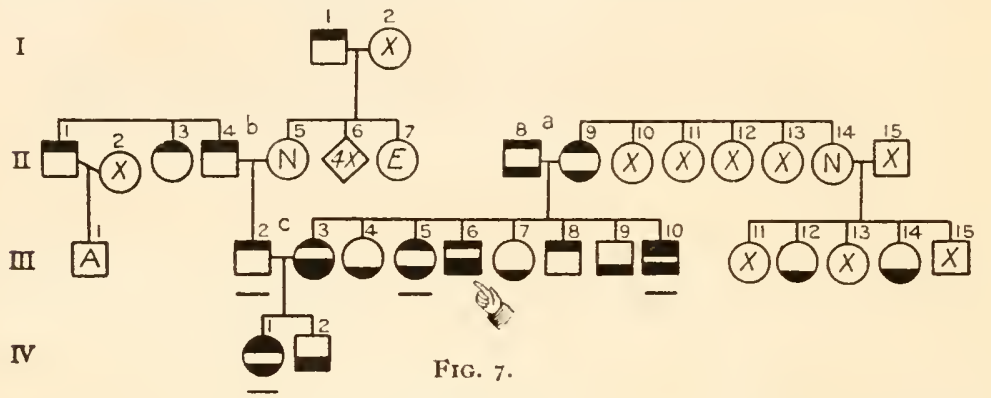

Figure 7.-I-1, of a fiery temper; easily irritated, quarrelsome, and shrewd. II-r, alcoholic, self-willed and indolent. II-3, quiet and cheerful but self-willed. II-4, alcoholic, arbitrary in his home, severe, stern, and inflexible, but charitable, and a "good man." II-5, quiet, gentle, pleasant, not complaining. II-8, had severe periodic headaches; in disposition was easy. quiet, not easily excited, and full of fun. II -9 , had periodic sick headaches, but was cheerful and not easily disturbed. II-I 4, mild and calm but nervous. III-2, at seven had spasms; became violent when under the influence of alcohol; threatened to kill his wife and children; was self-willed and stubborn. III-3, always nervous; imagines diseases and weeps. III-4, has migraine. III-5, at 49 became suicidal and homicidal; was nervous, excitable, delusional, and refused to eat. III-6, was very nervous and subject to sick headaches; at 40 he shot himself, thinking that his love was unreturned. III-7, had migraine. III-8, selfimportant, rather rakish, and a gossip; is $S x$ at 68 and has delusions as to his diseases. III-9, nervous and subject to headaches. He threw himself in front of a train. III-10, nervous and subject to headaches; was mild-tempered; became homicidal; had delusions of persecution and of his wife's infidelity at 43; asked to be hung; became excited; assaulted the attendants. III-12, doctors herself for kidney trouble; is nervous. III-13, a foolish old woman. III-I4 peevish and discontented. III-I5, is very nervous. IV-I, had convulsions in babyhood; at 28 became depressed; was more irritable and excited during the menstrual periods; later she became excited, violent, and destructive, but not homicidal nor suicidal. IV-2, quiet, indolent, an inordinate smoker. (22:252.)

FIgure 8.--II-3, had periods of violence. II-4, not bright but worked hard. II-5, considered "foolish." II-7. had a vigorous temper; used to fight her sons and neighbors; was $S x$. III-1, $S x$. III-2, at 46 had violent spells of laughter and rage; was homicidal, silent, disagreeable, and profane. III-5, alcoholic, quarrelsome; killed a man; died by cutting the arteries of wrist when intoxicated. III-7, $S x$. III-8, $S x$. IV-1, hysterical at times; bites her nails; worries often. IV-3, sometimes hysterical; bites her nails; has a short temper. IV -5 , became melancholy and hysterical at 24 , then stormy, destructive, homicidal and suspicious of her husband's fidelity; now quiet and depressed, with stormy, violent periods. $(56: 32$.)

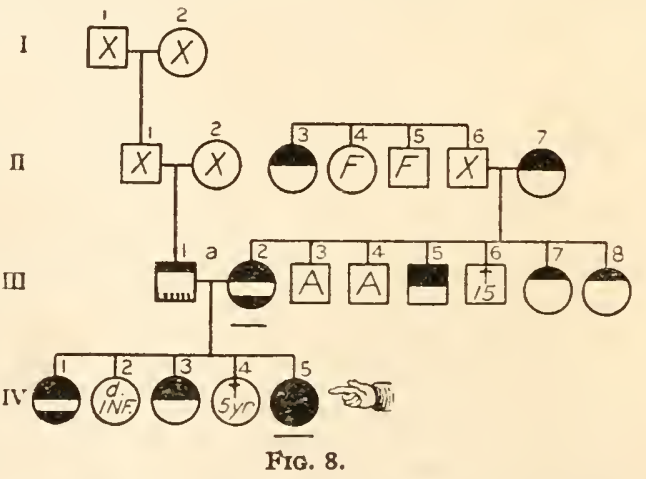


FIGURE 9.-II-2, jolly. III-1, had a periodic psyclosis. III-2, became hysterical and melancholy; at 2.5 drowned herself. III -3 , not nervous nor emotional. III-4, alcoholic, quarrelsome, and extremely erotic. III-6, nervously stable. III -7 , had unconscious spells; hung herself. IV -2 , has periodic headaches; was depressed at the menopause. IV -3 , inferior mentally; drinks to excess; is quick-tempered and domineering. IV-5, quicktempered, nervous, crabbed; drank periodically; had hallucinations and committed suicide after a drinking spell. IV-6, very erotic and hottempered. IV -7 , was morose, irritable, insane; attempted suicide. IV-8. irritable and alcolsolic. IV -9 , has a violent temper and periodic sick headaches. $\mathrm{V}-\mathrm{I}$, has periodic headaches and is quick-tempered. $\mathrm{V}-3$, const $\mathrm{i}$ -

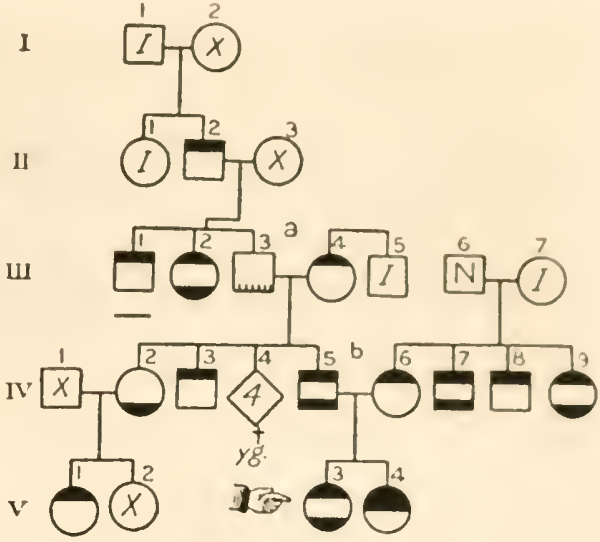

FIG. 9. tutionally inferior; a moral degenerate; is nervous and unstable; twice attempted suicide. $\mathrm{V}-4$, an actress who is obstinate, irritable, and passionate; after childtirth she became deranged and is now obstinate, silly, and shameless; has attempted stricide. (21: 118.$)$ N. B.-The symbol III 2 shotild be half black below:

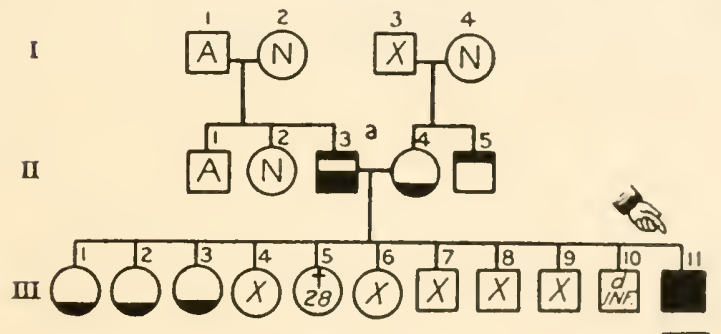

I'Ig. 10. ligurlis 10.-I-2, well and capable. I-4, harl good health and was capable mentally. II $\rightarrow$. well and caprable. II-3, when under the intluence of liquor had a violent temper and was sumetimes abusive; after a period of intoxication, when much depressed, he committed sticide. II-4, slow in thought and speech. II-5. deserted from the German army and canie to America. III-1, at 50 had sick head.

aches. III-2, had occasional sick headaches. III-3, had a nervous breakdown and was depressed for a time. III-11, had periodic headaches and nansea; was unsocial but gentle: after a fall when 21 he became irritable, excited, and apathetic; li:ul delusions und hallucinations; was homicidal and suicidal. $(44 ; 152$.

FIgURE 11.-I-1, eccentric; at 70 threw his money into a pond and jumped in after it to drown himself; 9 years later he lianged himself. II-1, not successful in business. II-2, not nervous. II I-2, jilted her lover and married another out of spite. III-3, a iniser; nervous, restless, afraid to be alone. II I-4, alcoholic, honicidal, and suicidal. III-5, hat St. Vitus's dance; was nervous and irritable. III -6 , very untusical; would work and loaf alternately: Sx; committed suicide by shooting. III-10, tyuarreled with lis wife over religion; disappeared and a month later his body was

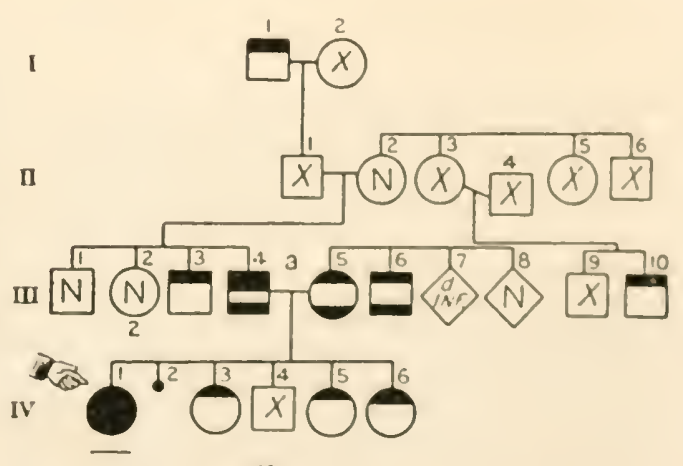

linc. 11.

found in the river. IV-I, a girl of 20; is stubborn and selfish; becane despondent and twice tried to drink carbolic acid; has dementia precox. $1 \mathrm{~V}-3$, a gadahont. IV-5, bright and happy at $16 . \quad$ IV -6 , an active and intelligent ehild of $9 . \quad(13: 272$.) 


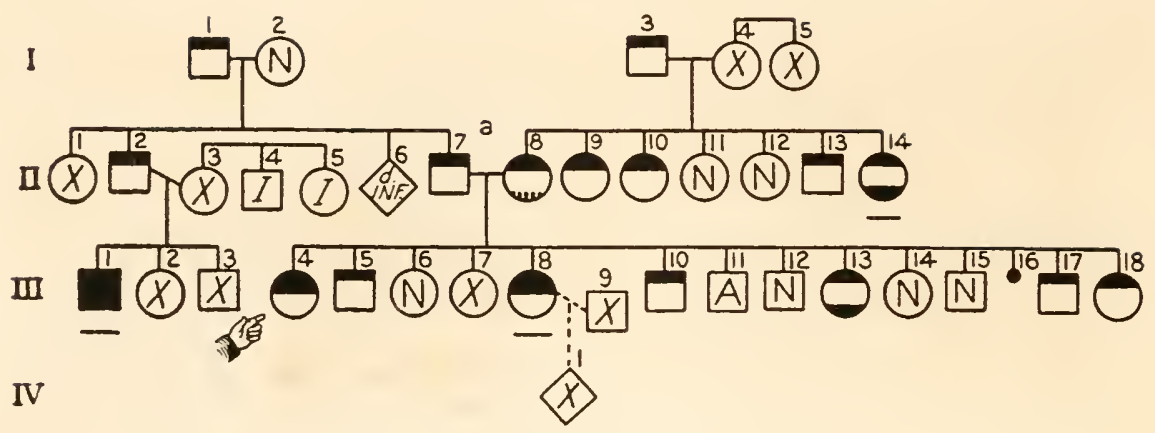

Fig. 12.

FIGURE 12.-I-I, traveled much; did not like to live in one place. I-3, became ugly when drinking. I-4, had spells when things became black to her vision. I-5, had mental trouble at the menopause. II-I, thrifty, II-2, alcoholic; bad-tempered; wandered around. II-7. a braggart; beadstrong, conceited, quick-tempered, alcoholic. II- 8 , hard-hearted, businesslike, garrulous. II-9, hard-hearted but religious. II-10, good-natured. II-II, pleasant and kind-hearted. II-13, queer and erratic; shot himself when drunk. II-14, inclined to worry; had delusions of persecution; became irritable and fault-finding; was hallucinated. III-1, a manic-depressive; excited and delusional. III-4, a great talker; at about 31 became violent, restless, and noisy; developed delusions and hallucinations and threatened to commit suicide. III-5, quick-tempered, a periodic drinker. III-6, matter-of-fact, frank. and brave. III -7 , slightly neurotic. III -8 , contrary and stubborn; hyper-religious; became noisy, restless, sullen, and had delusions. III-Io, hot-tempered, jealous, and irritable. III-12, calm, easy-going. III-13, discouraged and irritable; fusses and frets. III-14, sociable and pleasant. III-15, calm and easy-going. III-17, quick-tempered. III-18, quick-tempered and nervous. $(28: 1740$.

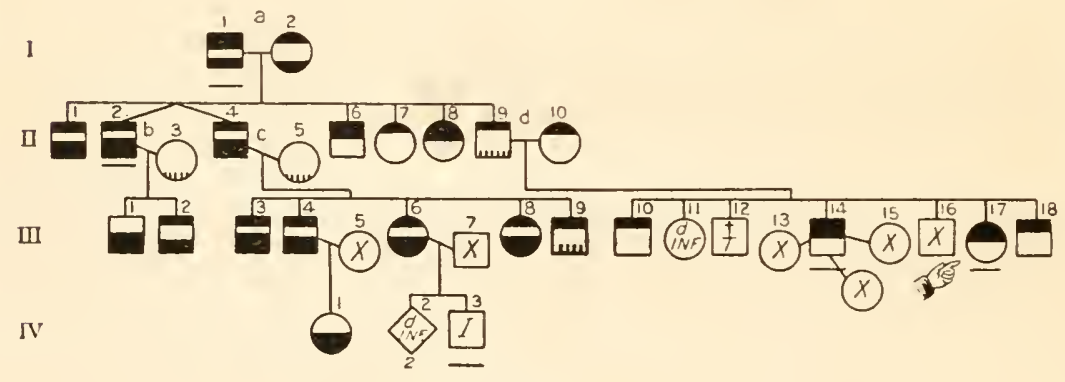

Fig. 13.

FIGURE 13.-I-I, would begin work and then drop it for something else; at 50 became excited and violent. II -2 , hypochondriacal and moody. II -1 , jolly; had "queer days"; was inventive; when past middle age he committed suicide. II-2, at 34 had delusions; was depressed and excited; suicidal and homicidal. II -3 , had no insanity in her family. II-4, a leader; subject to depressions; drowned himself. II-6, was easily excited, lively, not depressed; hanged himself. II -7 , quick-tempered, musical. II -8 , bright and happy but a little peculiar; committed suicide at 35 . II-9, very queer; would begin tasks and then leave them unfinished. II-1O, bright and capable. III-r, at 35 became depressed; attempted suicide by hanging. III-2, eccentric; inventive. III -3 , variable in mood; depressed; at 50 tried to hang himself. III-4, a mechanical genius; at about 33 he hanged himself. III-6, brooded; at 40 hanged herself. III -7 , gruff and unkind. III-8, at 35 was a manic-depressive. III-9, a mechanical genius. III-10, quick-tempered, irritable, and fussy. III-14, impulsive, irritable, and passionate; became excited; attempted to shoot himself. III-17, quicktempered; at 32 became excited; had acute mania. III-18, impulsive and always active and nervous. IV-1, subject to depression. (41:25.) 
FrguRr t 4.-I-1, eccentric, unsociable; lived the life of a hermit. II-r, of good character, reputation, and disposition; had nervous prostration. II-2, at 23 became excited and talkative; had melancholia; suffered from headiches; when 39 drowned herself. II-4, sensitive and moody. III-1, subject to depressions and long cryingspells; set fire to her house; was hysterical; took poison. III-2, had a violent, uncontrolled temper. III-3, nusical, cheerful, nirtatious, sensitive; was twice depressed and threatened suicide. (10:238.)

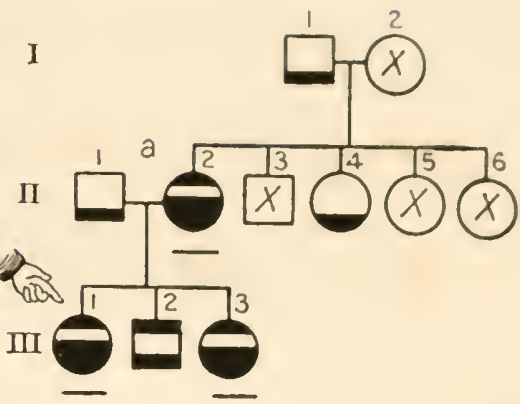

FIG. 14.

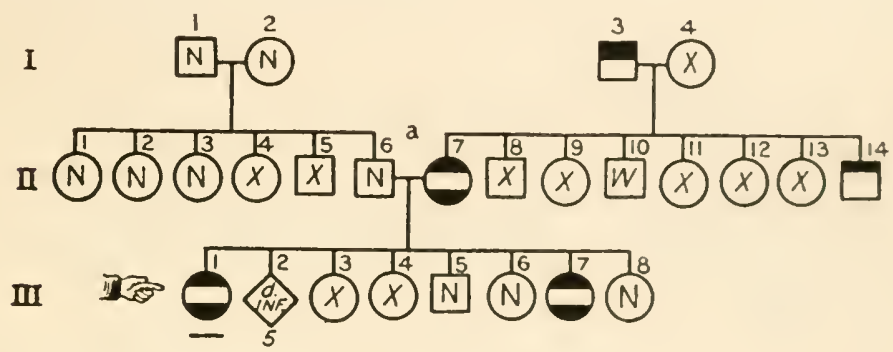

I.19. 1.5 .

Figure 15.-I-3, passionate and energetic; after being robbed, ent his thruat. I1-6, a schoolteacher, generous, religious, but not narrow. II-7, drove liorses like a man; after her sister's murder did not like to go ont and conld not sleep without chloroform for weeks. II-14. inventive. III- 1 , as a child was cruel; $S x$ : subject to nervous headaches; at 43 tried to eut her throat; has delusions of being pursued by the devil; luad hallucinations of sight and hearing. III-3, has nervous spells. III-5, is easy-going. III-7, had hysterieal spells, sometimes for 3 hours; worries for feur she will go insane. III-8, of an even, happy disposition. (40:471.)

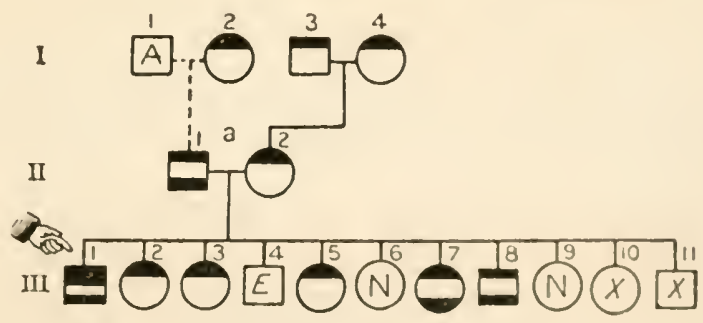

I'IG. 16.

FIGURI 16.-I-1, weak constitutionally. I-2, uf inferior, untit cliatracter; $S x$. I-3, energetic and capable. I-4, irritable. II - t, a clironic drunkard who in drunken rages threatened his wife and became suicidal; a choreic. II-2, extremely nervous; lacks decision. III-1, as a clibl was self-willed, quick-tempered, and irritable; at 15 was choreic; at 22 showed a wanderlust; drank heavily, and became suicidal and homieidal. III-2, of a nervous temperanent. III-3, coarse-spoken. III-5, quick-tempered. III-6, cuergetic, active, and refued. III-\%, ut 20 is hysterical. III -8 , nervous, irritable, alcoholic. III-10, 2112 is bashful and reficent. (21 : 594.) 


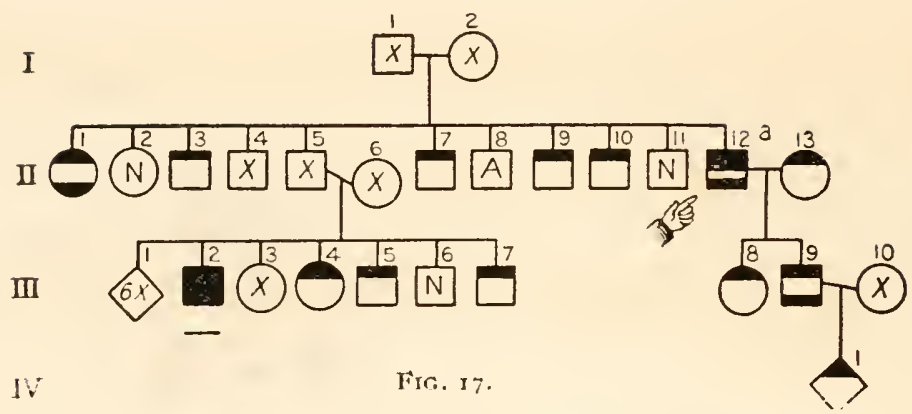

FigURA I 7.-II-1, quick-tempered, irritable, "cranky," envious, jealous, and probably depressed at times. II-2, of a quiet disposition. II-3, quick-tempered, rather nervous; had a habit of talking to himself. II-5, a highly respected farmer. II -7 , somewhat irritable and quicktempered. II-9, irritable and sexually passionate. II-Io, quick-tempered and cruel to animals. II-II, of good reputation. II-I2, had nervous headaches; was highstrung and irritable; had a high temper and yelled when things got in his way; used to hide himself. II-13, at 91 was restless and rather childish, but not demented. III-2, always nervous and highstrung and "cranky"; at $4 \mathrm{I}$ was committed for suicidal attempts and was depressed and seclusive; at 44 was depressed, suspicious, seclusive, and irritable; later he was violent and homicidal. III-3, has severe neuralgic headaches. III-4, cheerful and musical. III-5, of an even disposition but quick-tempered. III-6, of even disposition and temper. III-7, highstrung, social, and genial. III-8, always highstrung and "cranky." III-9, appears restless, irritable, and gloomy; is sometimes depressed. IV-r, nervous and quick-tempered, but not depressed. (ro:353.)

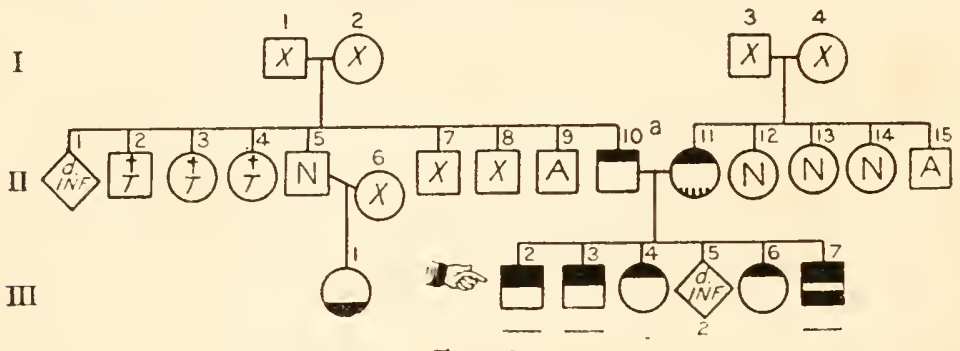

Fig. I 8.

FIGCRE 18.-II-5, of a quiet disposition. II-10, a hard drinker; did not worry; enjoyed humor; would chase his family with a cane. II-I I, of a cheerf11 disposition, but was restless; must be up and doing. II-12, cheerful and contented; religious. II-13, bright and fine-spirited. II -15, of a quiet and peaceful disposition. III -1 , lives alone in a shack; does not get along with people; has always been queer. III-2, drank to excess; was cross and irritable; at 37 threatened suicide by drowning; was excitable; had delusions and hallucinations. III -3 . quick-tempered; had delirium tremens; had hallucinations. III-4, bright; had a good sense of humor. III-6, cheerf $u l$, bright, and happy. III-7. h ad convulsions; was irritable; had hallucinations; was noisy at times, but mos 1 ly depressed; became ugly and often threatened suicide. $(45: 76$.)

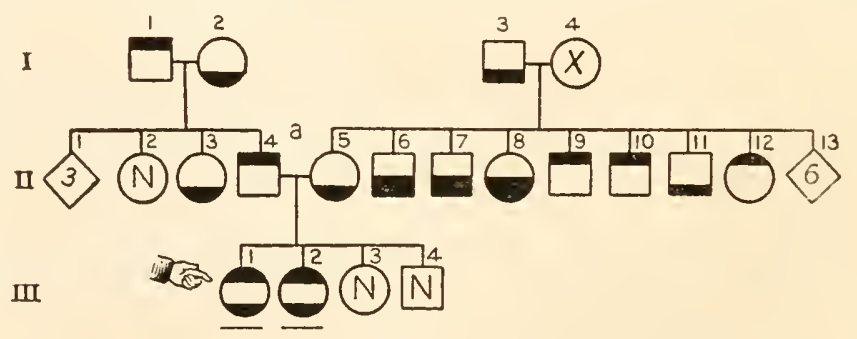

Fíg. 19.

FIGURE, 19.-I-I, frank and decided in speech. I-2, of a meek and quiet disposition. I-3, worried and hanged himself. II -2 , an excellent housekeeper. II-3, had nervous prostration and sick headaches. II-4, stern but generous. II-5, peevish and melancholy. II-6, committed suicide at the age of 30 by using chloroforn 1 and by hanging. II-7, at 35 cut his throat. II-8, grew despondent; was catatonic. II-9, irritable. II-10, quick-tempered, 
Figuris 19-continued.

irritable and nervous. II-11, had severe headaches. II-12, of at gay, lively dispusitiun. III-1, slashed her neck and throat with a razor aud cut a liole over her heart. III-2, very sensitive; was violent at times; tried to choke herself. 111-3, of an easy-groing disposition. III-4, easy-going. (11:130.)

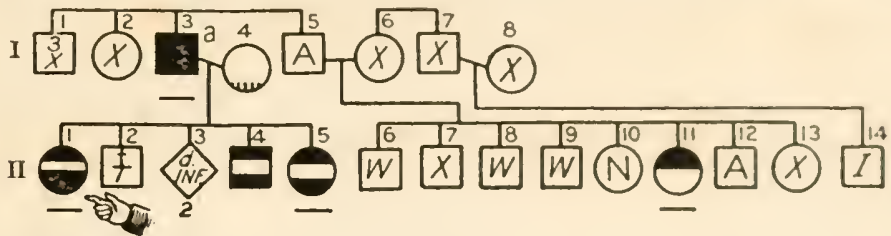

Fis. 20 .

FigURL 20.-I-3, oratorical, never stuck to anything long; was violent-tennjerced; tecame de. pressed and then violent at the age of 46 ; diagnosis, acute mania. I-5, had delirim tremens. I-6, deteriorated mentally. II-1, broke down under strain of drudgery and became violently excited; diagnosis, involutional melancholia. II-4, dissolute and unreliable. II -5 , irascitsle; became violent. II-10, has common sense. II-11, had acute hysterical mania; was alcoholic. $(13: 120$.)

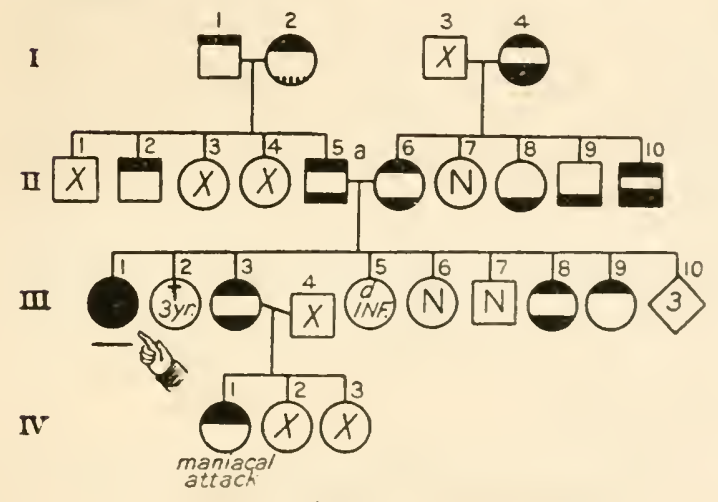

Fitg. 21 .
Figurk $21 .-\mathrm{I}-1$, rough, I-2, Sx. I-4, had religious mania. II-2. hard-working. II-4, "not right." II-5, lazy, cross, nas$t y$, and domineering. 11-6, suspicious and untruthful. II 8 , worried without losing her mind and was disagreeable. 11-9, would tremble and perspire. II-10, alcoholic and $S x$; had delusions of persecutions and suicidal impulses; during one spell he fell upon his knees and prayed in a way that renuinded one of his mother's attacks. III-1, had hallucinations and fits of sereaming: suicide was feared hy others; at 20 had spells of despondency and then of wild acting with homicidal threats; at the hospital had a depressive stupor. III-3, flighty and $S x$. III -
bright. III-8, has flight of ideas, is nervous, and worries. III-9, quick of tongue and full homicidal threats; at the hospital had a depressive stupor. III-3. flighty and Sx. III -
bright. III-8, has flight of ideas, is nervous, and worries. III-9, quick of tongue and full of devilment. IV-1, had a maniacal attack when young; laughed and was very active; recovered. (40:795.)

I

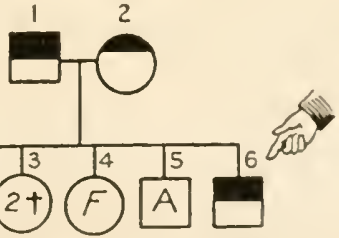

I.IG. 22 .

FigURI: 23.-I-1, extremely crucl and sellish; was irritable and had a vile temper; was submental. I-2, was twice excited religiously and laad delusions; diagnosis. manic depressive; committed suicile by taking carbolic acid. II- $t$, slow and rather incompctent farmer; attempted suicide by taking carbolic acid at the same age as his mother did. II-2, fechleminded and $S x$. II-3, intelligent ant somewhat refined. II -.1, left home and edncated himself. II-5, feeble-minders. II-6, sub-mental; lazy, slow, and indigent; w:ants fo run away. $(1.4: 173$. ling1'k 22,-1 1 , cut his throat with a razor. $1-2$, always queer. II- 4 , thinks she may cut her throat. II-6, cut his throat as lis father dicl. (6, : 328.)

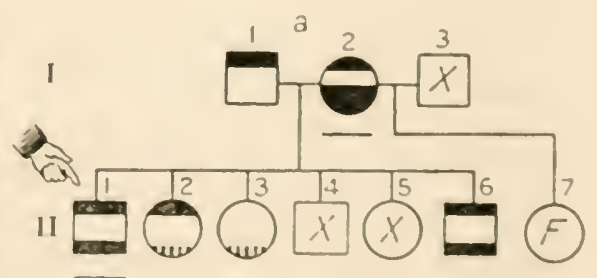

I'Tri. 23 . 


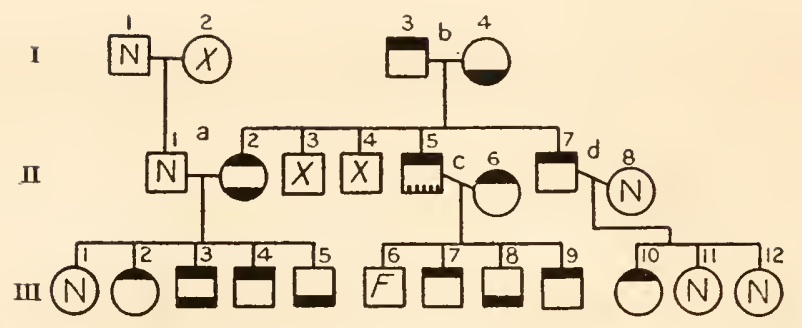

Fig. 24.

FIgURE 24.-I-I, easy-going, calm, and collected at all times. I-2, quiet, deliberate, and masterful. I-3, highly nervous, tempestuous, and full of the devil in a harmless way; was always walking up and down; loquacious. I-4, had a nervous temperament; was of the worrisome type, continually fret ting; was dubious; liked to be alone, not social. II-I, calm, deliberate, decided, and steady. II-2, of a nervous temperament, but had great vitality; worrisome; "up and at it"; undertook more than she could do. II-5, nervous, gets "red-headed," easily loses control of himself. II-6, quick, efficient, reliable, dependable, nervous. II-7, was markedly nervous. II -8 , normal. III-I, not nervous, except under severe and prolonged strain. III-2, nervous, efficient, neat; a good manager. III-3, nervous, erratic; loses temper easily, and breaks under a strain; timid, diffident. III-4, quick, shrewd, aggressive, insistent, curious, nervous. III-5, "slow coach"; has anger of the sullen type; not aggressive. III-6, feeble-minded. III-7, successful; a fast walker; restless, snobbish, conceited, worrisome. III-8, strongly religious, conscientious, retiring, rather seclusive; "not a live one." III -9, calm, progressive, conceited, parsimonous; a great worker. III-IO, not strong mentally nor physically; gossipy, a tale-bearer; flighty and nervous. III-II, calm and pleasant. III -12 , calm, likable, not nervous. (Smi.)

Fig. 25 .

Figure 25.-I-3, temperate. II-I, died at 54 from alcoholism. II-2, went on periodic sprees. II -3 , "best of the lot." II -5 , took life easily, was jovial, sociable, outspoken, blunt, haughty; had delirium tremens twice. II-6, domestic, of good common-sense; did not worry; jolly, was subject to headaches, vertigo, and dizzy spells. III-I, reticent. III-2, alcoholic; fond of men; neglected his wife; deteriorated mentally. III-3, talkative, deceitful; a slanderer; stubborn, yet cheerful and light-hearted; had headaches, attacks of the blues, and periods of exhilaration; was excited by men; hyper-sexual; at about 40 was over-affectionate and then vicious toward ler children; when about 54 became excitable and imagined things. III-4, thrifty; fond of men; moody; jolly, and agreeable, and then absorbed and uncommunicative. III-5, cheerful but not sociable; goes on sprees. III-6, a loud-talker, highly excitable; screamed at and tongue-lashed the investigator. III-7, not nervous nor excitable. III-8, fond of the socicty of men; cheerful and jolly, but quarrelsome when drinking. III-9, quick-tempered and unreasonable. III-I1, frank, gracious, refined; of easy-going, quiet disposition. III-12, of a nervous temperament and of a worrying disposition; drinks to excess. III-13, a worrier; quick-tempered, over-active, easily excited; has had several nervous break-downs. III-I 4 , fears that he may commit suicide by impulse; has slight hallucinations of hearing; is subject to fainting spells. IV-1, alcoholic, lazy, unambitious, $S x$. IV -2 , temperate but not honest. IV-4, temperate, agreeable, pleasant, and kind. IV-5, headstrong, lond, excitable, high-tempered; married secretly; forged notes. IV-ro, an actress; malicious, irritable, high-tempered, highstrung, unreasonable, and dictatorial. IV-I2, of a mild, genial, good disposition. IV-13, of a nervous temperament and quicktempered. IV-I4, of a good, quiet, mild disposition. IV-15, "rather uppish" and quicktempered. IV-16, talkative and rough. IV-19, at i6 had nervous prostration; was quiet and melancholy, seclusive, easily excited and confused; at childbirth, when 32 , was delirious, 
FIGUR1: 25-continued.

excitable, and hysterical. IV-20, quick-tempered, impulsive, wants to be on the go. IV-at, bright; disappointed in love, had the blues. IV-23, at one time was very nervous. IV-24. basliful and nervous. IV-26, easily excited; loses her head quickly. IV -27 , nervous. IV-28, nervous; goes on sprees. $(V-29$, quick-tempered, excitable, nervuus; hus faintin. spells. IV -30 , has fainting spells. (V-8: 185.)

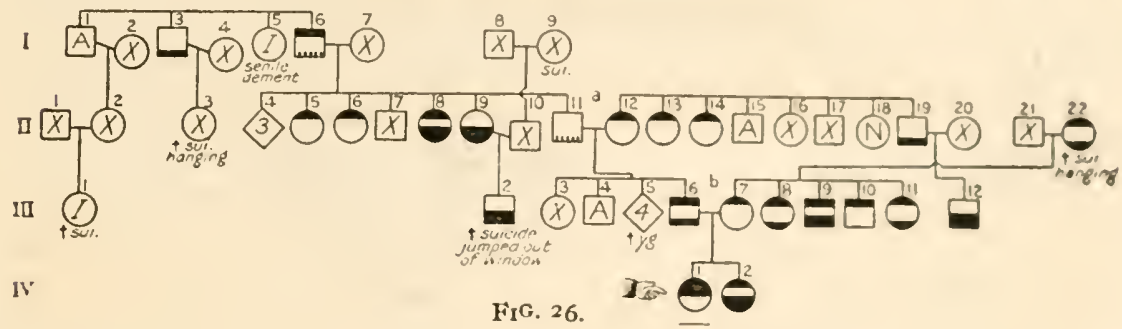

FigURf 26.-I-3, had nervous prostration. I-6, jolly and a great storyteller. I-9, committed suicide by hanging. II-3, committed suicide by hanging. II-5, lively and progressive. II-6, extremely nervous, quick-tempered, and impulsive. II-7, a dementia precox. II -8 , hysterical and melancholic; drowned herself. II -9 , became depressed and killed herself by shooting. II-11, mild-mannered. II-12, a lazy, careless, extravagant, $S x$ woman. II-13, restless. II -14 , lively and restless. II-17, a dement. II-18, of good health and even disposition. II-19, lazy and plodding. II-22, disagreeable and unsocial; hung hersell. III-1, always peculiar; committed suicide. III-2, committed suicide by jumping from window. III-3, has periodic insanity. III-4, a dipsonaniac. III-6, quick-tempered; drank periodically; when on a spree had l,allucinations and shot himself. III-7, S.x. III -8 , irritable, super-sensitive; grieves; in a rage throws things at random. III-9, when drunk gains delusions of grandeur; attempted suicide; has periodic depressions. III-10, a terrible drunkard and quick-tempered. III-11, of a fiery disposition; worries constantly and is irrational. III-12, depressed; killed herself by jumping from a window. IV-I, obstinate, irritable, and passionate as a child; became hysterical, trierl to hang herself and kill her child. $[\mathrm{V}-2, S x ;$ in despondency twice at tempted suicide. $(21: 143)$.

I

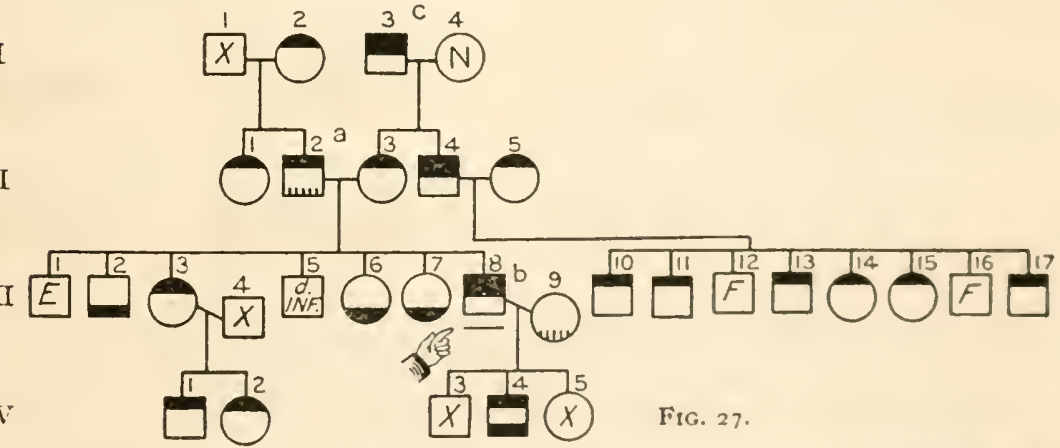

III

II

FIgurf; 27.-I-2, quick-tempered and lond. I-3, very nervous and cross; has a terrible temper. I-f, of a kind, good-natured, social disposition. II-1, high-tempered. II-2, hot-tenpered. II-3, has sick headaches and motor restlessness; is quick-tempered, easily cxciterl. ubusive. II- + , subject to convulsions; lawl violent outbreaks of temper; was brutal to animals; became violently insane and suicidal. II-5, an inbecile, quick-tenuped, careless. III-2, " mechanical genius; unsocial. III-3, constitutionally inferior, has lits of anger nnd temper. when slue throws things. III-4, of poor mentality. III 6, has severe migraine. III-7. has much headache; had nervous prostration and elepression. 111-8. sulky and impaticnt as a boy; drank; quick-tempered; lomicidal and suicidal; has hallucinations and delusions. III-9, strong and capable. III-10, St. III-11, mentally weak; lazy; had fits of anger. III-13, feeble-minded, unsocial, selfish, has mid rages. III- -4, fechle-minderl and migrainons, quick-tempered. III-15, feeble-minded, quick-temperei, easily exciterl, unsociable. II -17 , feeble-minded, nervous, cross, of ngly disposition. IV-1, abuorual temper. IV-2, feeble-minded and of almormal emper. IV-f, (quiet, stern, seclusive. (21: fof.) 


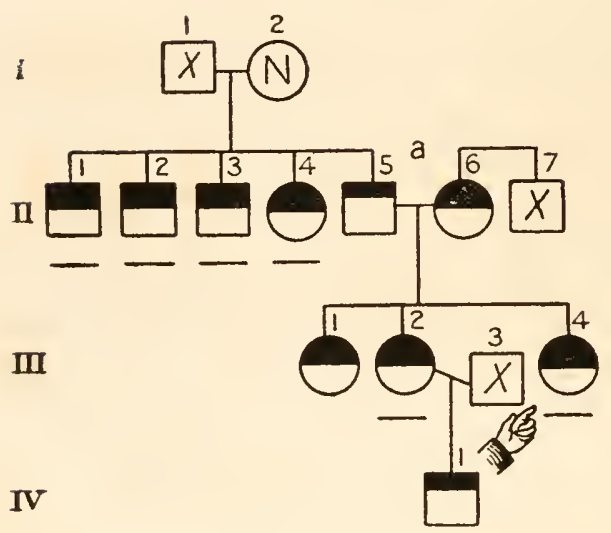

Fig. 28.

FIGURE 28.-I-I, penurious; a heavy drinker. I-2, sweet in disposition; of good mentality. II-1. flighty and ugly; had excited periods. II-2, erotic and violent; had chronic mania. II-3, had chronic mania. II-4, inferior; erotic; had chronic mania. II-5, penurious, slow, and selfish. II-6, garrulous, jumps from one topic to another; has sudden emotional changes; said to have attempted suicide. II-7, lives alone; is rather peculiar. III-1, had a nervous breakdown twice; is very hot-tempered; jumps from one topic to another. III-2, had delusions of persecution; threatened her neighbors; had hysterical attacks. III-4. attempted suicide when 16; was disturbed and hysterical at 19; had suicidal impulses, though not particularly depressed nor discouraged at the time. IV-1, gets excited and hysterical. $(28: 56$.)

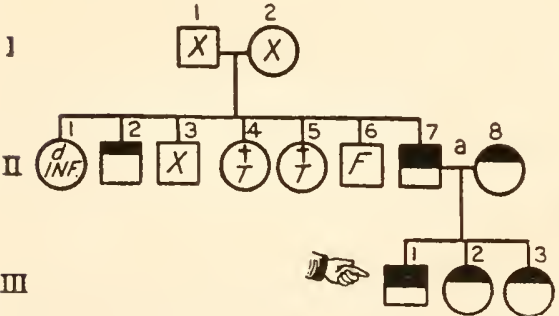

Fig. 29.

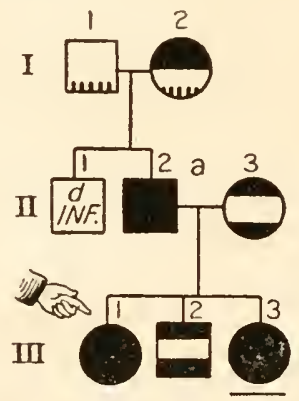

Fig. 30 .

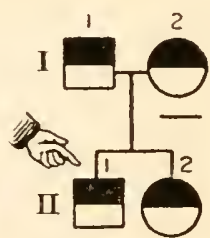

Fig. 31.

FIGURE 29.-II-2, probably feeble-minded; egotistical and boastful, but of kindly, even disposition. II -7 , excessively alcoholic; $S x$; assaultive; killed limself by hanging. II-8, immoral. III-r, excessively alcoholic, suicidal and homicidal; cut his throat twice; stabbed at landlady; was excitable and violent. III-2, $S x$. III-3, $S x$. (13:172.)

FIGURE 30.-I-1, lackadaisical, easy-going, and good-natured. I-2, very nervous and hyperactive; became demented and trembled; was irritable, easily excited; had delusions and a terrible fear of fire, in the presence of which she behaved as if insane. II-2, nervous, absent-minded, easily excited, irritable, and of terrible temper; trembled; was reticent and unsocial; was depressed most of the time; would grieve and cry. II-3, greedy, bossy, irritable, selfish, always "a-jawing." III-I, insane since 13 ; is morbid and blue most of the time; attempted suicide several times; became hysterical and hilarious and then blue and depressed. III -2 , high-tempered; became insane after being rejected in love. III -3 , at 22 showed insanity; was $S x$; became depressed and suicidal; was lachrymose, absent-minded, and forgetful. (2 $1: 345$.)

FIGURE 31.-I-1, subject to sprees; suicided with poison. I-2, had acute mania; was noisy, violent, and destructive. II-I, is choreic; very alcoholic; $S x$. II-2, $S x$, restless and twitches. $(7: 312$.) 


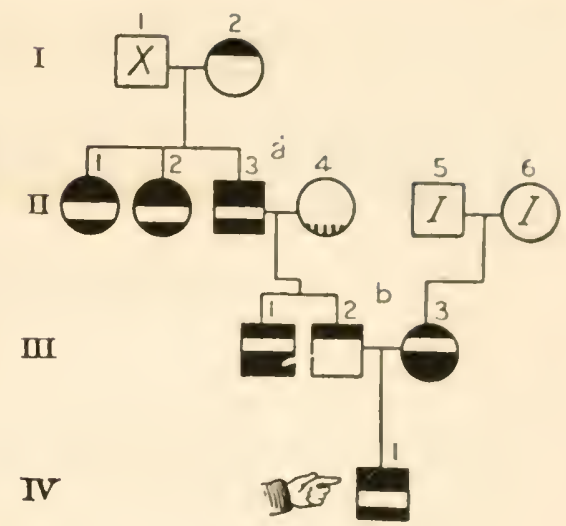

Fic. 32 .

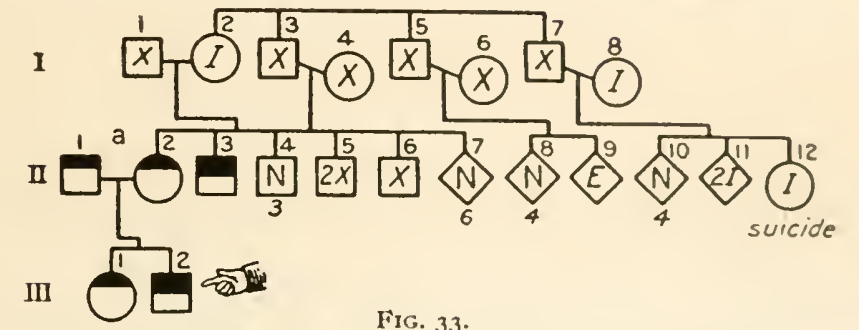

Fir. 33.

FIgurg 33.-II-1, went West, deserting bis wife. II-2, very extravagant; a religious fanatic. II-3, shot a man, but not fatally; ran away. II-12, killed herself with poison. III-I. feeble-minded and a religious fanatic. III-2, below grade mentally; suddenly became restless and violent; later he killed a boarder; cut his sister's throat and shot himself. ( $44: 193$.

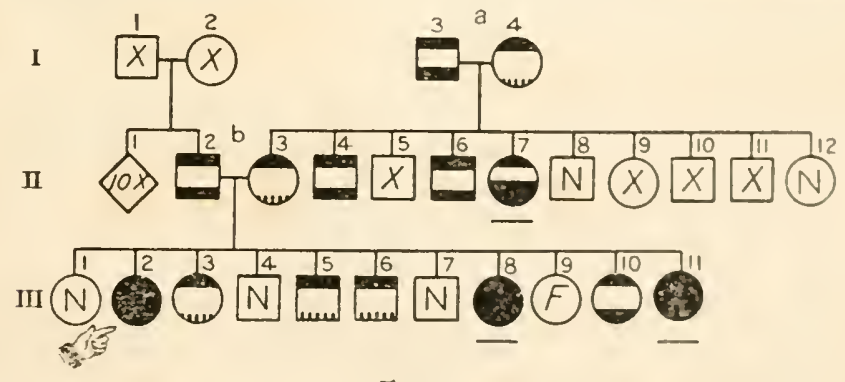

Fig. 34.

FIGURE 34--I-3, quick-tempered; frequently dead-drunk. I-4, strong-ninded, died with apoplexy. II-2, firm and determined, easily prejudiced, obstinate. II-3, quick-tenpered; every summer was unusually active. II-4, quick-tempered and contrary". II-6, a "shout ing Methodist"; more excited over religion in winter than in summer. Il-7, ardent in religious beliefs; became depressed and confused; had religious delusions. 11-12, slow, practical, and matter-of-fact; could not "get religion," so became a dislseliever. III-1. bashful as a girl, slow, even-tempered; ardent in religion. III-2, attacks whicls take form of depression began at 20; sits mute and indifferent; when angered flies into a temper; disposition always quick, ugly, self-centered and selfish. III-3, quict and social, but has a tonigx. III-4. silent but sociable. III-5, quick-tempered. III-6, quick-tenpered anel a rover. III-\%, of quiet disposition. I11-8, pleasant and jovial, but in nental attacks which fregun at 16 she is violent and disorderly; is then cross and ugly, later confused, excited, and hallucinated, then depressed. III-10, has unusual conversational ability; is religions. III-11, when 23 had first attack of depression and would not talk; in ulater attack talked all the time and was very active; has sudden outbursts of temper; has a mania for collecting. (28: 29.3.) 


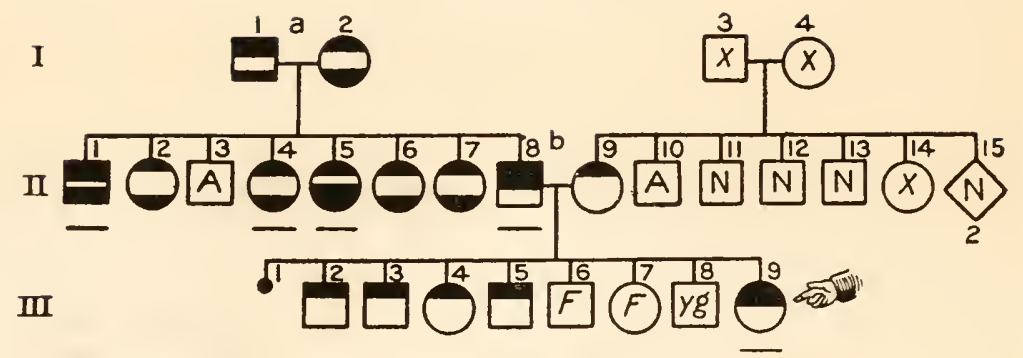

Fig. 35.

FIgURE 35.-I-1, often ugly and disagreeable to his wife; alcoholic; highly erotic, seduced his grand-daughter. I-2, queer; became irritable; had a paralytic stroke and demented. II-I, alcoholic; worried; was seclusive, then loquacious, excited, restless, and destructive. II-2, irritable, secretive, eccentric. II-3, a dipsomaniac. II-4, hypochondriacal, delusional, excitable, and hysterical. II-5, weak-minded; easily excited, occasionally threatening; in acute dementia refused to talk or eat. II-6, irritable and hard to get on with. II-7, nervous, secretive, suspicious, insolent. II -8 , alcoholic; at 48 became excited, talkative, expansive, had schemes for making money, and was emotional; he wanted to shoot someone and was noisy and assaultive. II-9, of low intelligence; a braggart. II-14, had hallucinations after an operation. III-2, a great braggart, but not alcoholic nor $S x$. III-3. goes from one job to another; very $S x$, alcoholic. III-4, boasts of her immorality. III -5 , submental; alcoholic and ugly. III-6, feeble-minded; insolent; drinks all he can get at I 6. III-7, defective. III-9, unhappily married at 26 , she became irritable, violent, restless, and destructive; at the hospital she was very flighty and destructive; Wasserman negative reaction; diagnosis, mania. (28: 1328.)

FIgure 36.-I-I, strict, severe, over-religious, quick-tempered, but not moody. I-2, went West; inventive. I-3, alcoholic; disappeared with other people's money. I-7, excitable, high-strung; variable in moods; $S x$. I-8, seclusive; irascible and disagreeable, very moody. II-r, temperate. II-2, peculiar; has no regular occupation. II-4, "the worst devil (as a wife) that ever got out." II-5. agreeable and good-natured but moody;

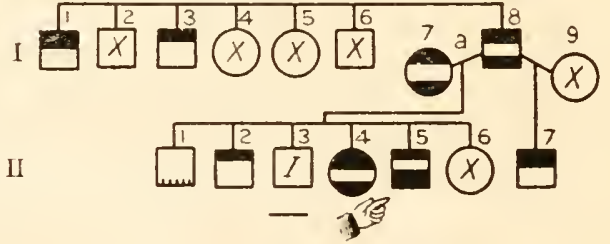

Fig. 36 . when 30 shot himself. II -7 , did not get along with lis stepmotler and at 21 hanged himself. $(28: 1604$.)

FigukE 37.-I-1, an inveterate drunkard and a notorious sex offender. I-2, probably feeble-minded; a member of a lawless gang. II -1 , alcoholic and $S x$. II-2, $S x$, alcoholic. II-3, $S x ;$ at 20 had delusions; was noisy and quarrelsome; at 40 (fourth admission) was very excited and made threats of violence; diagnosis, chronic mania. II-4, alcoholic, $S x$, but honest. III-r, was epileptic in youth; at 46 was delusional and hallucinated; at one time was excited, restless, and apprehensive. III-2, reliable and slow. $(28: 241$.
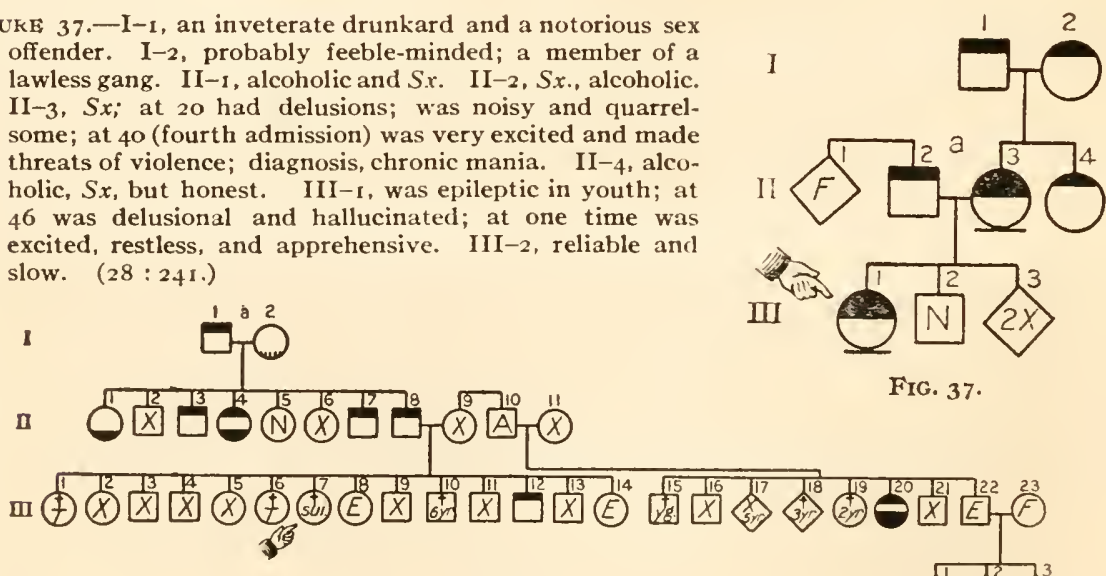

FIG. 37.

IV

Fig. 38 .

FIGURn 38.-I-I, alcoholic; a powerful man and took what he wanted by force. II-1, "poor and dispirited." III-3, rougl, superstitious, a hard drinker. II-4, became violent at 30 , but 
FigukF 38 -continued.

grew more rational; drank to excess; was seclusive and easily irritated. I1-7, died in a penitentiary, where he was put for knifing a man in a fight. II-8, was very ugly when roused: a tyrant in his home; his wife was afraid of her life. II-9, rather clildish in old age, wan. dered around at night. II1-7, committed suicide by poison. 11I-8, became insane. 111-13. very zealous and enthusiastic about religion; prays in pullic, breaks down, and cries, lut is not melancholy. III-13, reticent; not a religious fanatic. 11I-20, had three attacks of agitated depression; worried; had a complaining manner; had delusions of unworthiness. (28:840.)

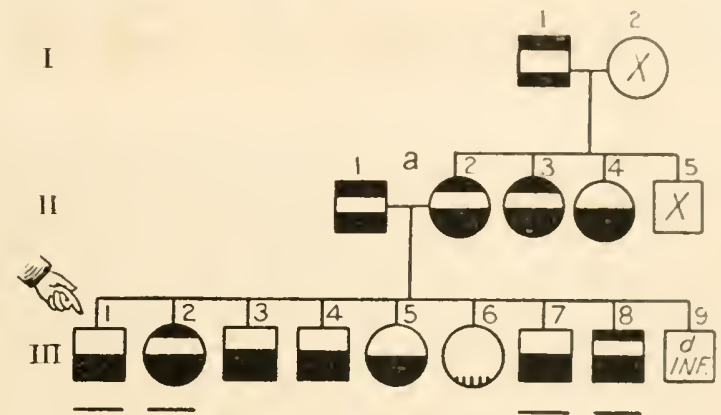

Fig. 39 .

FIGURE 39.-I I, serious; strict with his children. II-1, had a devilish temperament; would fly into a rage at any little thing which displeased him. II -2, loqnacious and boisterous; was worried and nervous when her husband was about; died weak and complaining. II-3, is melancholy and hysterical. II-4, melancholy, apprehensive, lachrymose; committed suicide by drinking carbolic acid. III-I, worried, became depressed and attempted suicide. III-2, had outbursts of temper; was inclined to worry; became delusional; tried to suicide by jumping into a well and by poison. III-3, melancholy; had ideas of suicide. III-4, had spells of depression. III-5, became worried and melancholy; was a "faith healer." III-6, bright and cheerful. III-7, depressed; he committed suicide by jumping from a roof. III-8, worried and despondent; suicidal in intent. $(28: 999$.

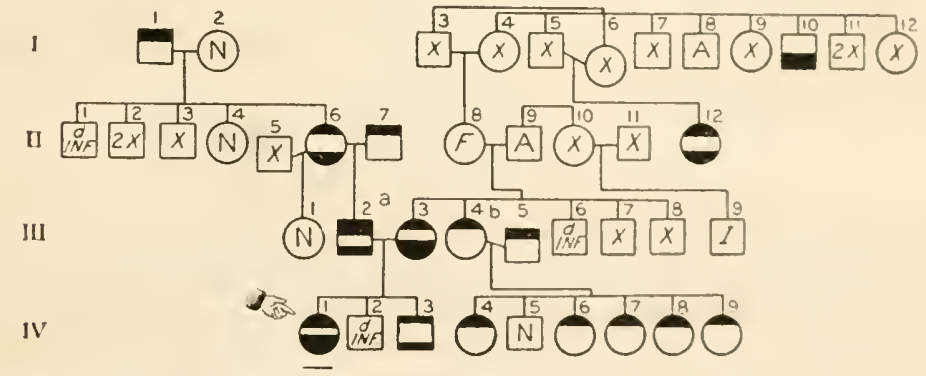

Firg. 40 .

FIGURE 40.-I-I, very $S x$. I-2, of excellent reputation. I-9, always nervous. I-ro, became depressed and committed suicide by turning on the gas. II-3, went West. II-4, of calm. even disposition. II-5, of bad reputation, alcoholic. II-6, migrainous; violent-tempered. hysterical. 1I-7, criminalistic; implicated in a roblery, le fled out West. II-12, migrainous, gartulous, and dramatic. III-1, of caln, even temperament. III -2, S., intemperate, abusive and violent when drunk. III $-3, S x$ and alcololic; had laysterical fits followed by deep melancholy. III-4, Sx, but became energetic and capable. 11I-5, Sx, of fiendish temper, alcoholic. III-7, stubhorn, went to Sonth America. III-8, ran away to the llest. III-9, had chronic delusional insanity. $1 V-1, S x$, has terrible fits of temper and morbid spells, when she refuses to eat; has suicidal tendencies. IV 3 , inupertinent, disagrecable, runs away. IV $-4, S x$. IV -5 , of good reputation, steady and efficient. IV $-6, S x$. IV -7 . $S x$. IV $-8, S_{x}$; has violent fits of temper. IV -1 ), has headache; is wayward and unmanageable; is subject to fits of temper. (9:145.) 


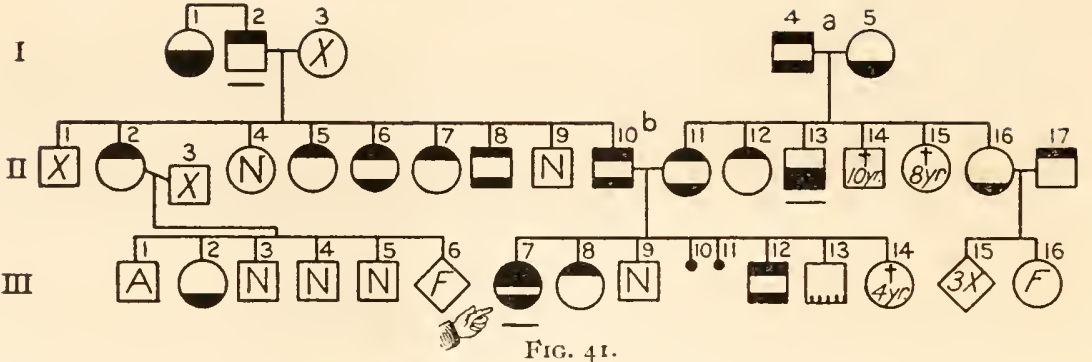

FIGURE 41.-I-1, very depressed; wants to die. I-2, excitable; worried over money and had acute mania. I-4, vivacious and full of fun; shortly before his death he had a cerebral episode not followed by paralysis. I-5, talked little; was fond of reading and going to church. II-1, went West. II-2, has hallucinations; is sharp-tongued and garrulous. II -5 , is talkative and restless; is hyper-religious; her actions are mildly manic. II-6, worried and complained; was emotional. II-7, excitable and nervous. II-8, alcoholic, excitable; prematurely senile. II-9, temperate, sunny-tempered. II-IO, quiet but rather quicktempered and seclusive. II-11, has a sharp, quick way of speaking; becomes blue and discouraged. II-12, very nervous; a poor sleeper; easily excited. II-13, alcoholic; became worried and depressed; had vague delusions of persecution; has long been subject to melancholy spells; threatened suicide. II-16, was sensitive to noise, apprehensive, and anxious. II-17. lazy; abusive to his children. III -2 , subject to sick headaches; became despondent and a paranoiac. III-3, steady and temperate. III-4, temperate. III-6, has sick headaches. III 7 , stubborn, highstrung, irritable, ugly, and disagreeable, $S x$; had a religious psychosis with hallucinations; was variable in moods, violent, and destructive. III-8, very nervous, disagreeable, and surly. III-12, surly, disagreeble, profane, and alcoholic. III-13. quiet and industrious. $(28: 1509$.

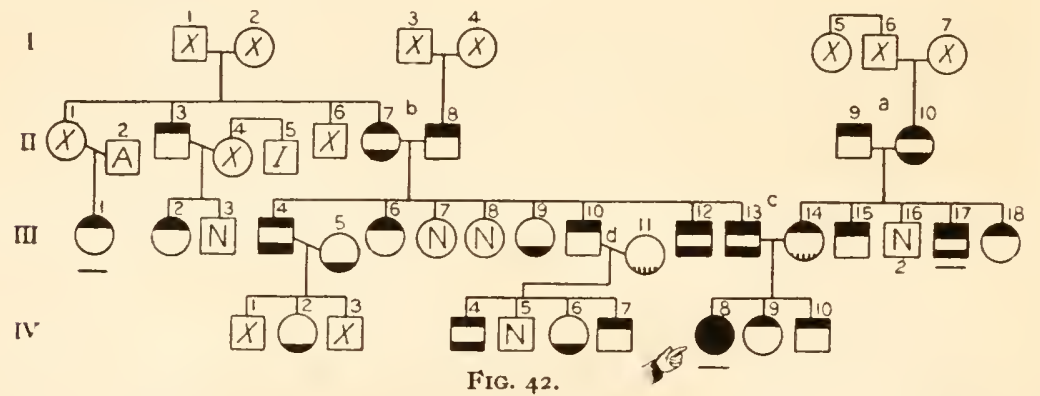

FIGURE 42.-I-2, stock showed tendency toward insanity. I-7, insanity on this side. II-3. thrifty, accumulated a fortune; alcoholic. II -6 , at 80 had hallucinations. II -7 , jovial, good-natured, had keen sense of humor; over-sensitive. II-8, very set in his ways and ideas, very religious, "odd," and argumentative. II -9 , nervous, excitable, fond of music; would fly into a rage; abusive; drank. II-10, of quiet, even disposition; at 81 wanted to run away, had hallucinations and paralysis. III-1, at 50 showed mental peculiarities; had delusions of reference and wealth; dresses fantastically. III-2, at 16 had a psychosis; a musician. III-3, upright and successful. III-4, excitable, erratic, stubborn. III-5, had periodic headaches. III-6, sociable, full of fun, popular with men. III-7, of quiet, even disposition. III-8, of good, social disposition. III-9, unsocial, never liked men, entered a convent. III-10, lively and full of fun; excitable and alcoholic. III-11, very nervous. III-12, naturally easy-going and kind; since a nervous breakdown, has become notional and hard to get on with. III-13, naturally cheerful but quick-tempered; uses morphine for his headaches. III-14, highstrung, fond of sports, contented. III-15, nervous, excitable, quick, musical. III-17, naturally jolly and sociable; fond of dances and girls; when 32 became seclusive, violent-tempered, and assaultive. III-18, rather nervous. IV-1, successful lawyer. IV -2 , has had 3 nervous breakdowns. IV -4 , bright, reticent, and bashful. IV -6 , easy-going, unambitious. IV -7 , bright, friendly, musical, inclined to be nervous. IV -8 , over-religious, bashful; subject to fainting spells in youth. At 19 had crying spells, then delusions, and attempted suicide; later assaulted his mother and sister. IV -9 , bright, highstrung, sociable, popular, musical, always "on the go." IV-10, jolly and sociable. $(45: 127$. 


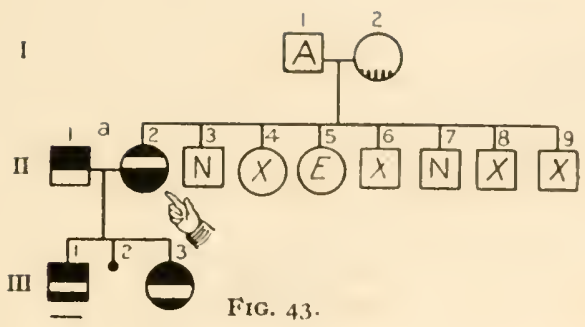

Fisuki 43,-II-2, a shiftless, worthless epileptic, at times violent and resis. tive; ngly and jealous, threatening his wife. Il-2, had mania for cleaning; at 62 becane inclanclioly, developed delusions of poverty, refused to eat, and died of starvation. II-7. hearty, rugged, capable man. II -9 . shrewd and thrifty. III-1, guick. tempered and seclusive; at 36 hal persecutory delusions and had hallucinations. III-3, talks loudly azd noisily; keeps house inmaculate; is on a tension. (28:625.)

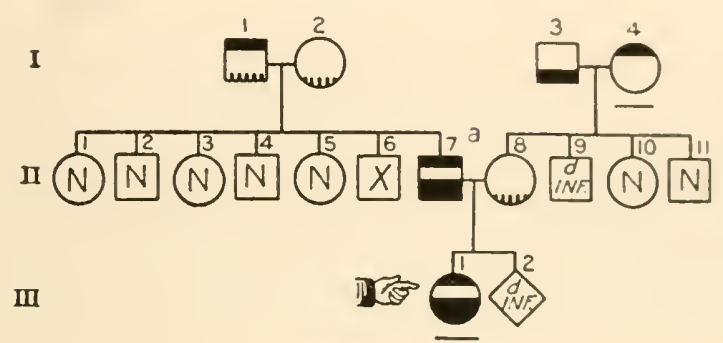

Fig. 44 .

FIGURE 44.-I-I, high-tempered but generous and affectionate. I-2, cheerful, quiet, eventempered, and stingy. I-3, temperate, even-tempered; memory began to fail at 60 . I-4, at 30 nervous, active, singing and talking constantly; chronically manic. II-I, calm, patient. and well liked. II-2, quiet, not unsociable. II -4 , mild and easy-going. II -7 , always highstrung and quick-tempered; at 67 worried and became depressed. II-8, not nervous. II-1o, of even, amiable disposition. II-11, good, steady business man. III-1, naturally lively and cheerful, but inclined to be moody and to worry. Always falling in love; jilted. she became depressed, cried, was mute and suicidal; later, lyyper-active, talkative, restless, and emotional, then depressed. (45:181.)

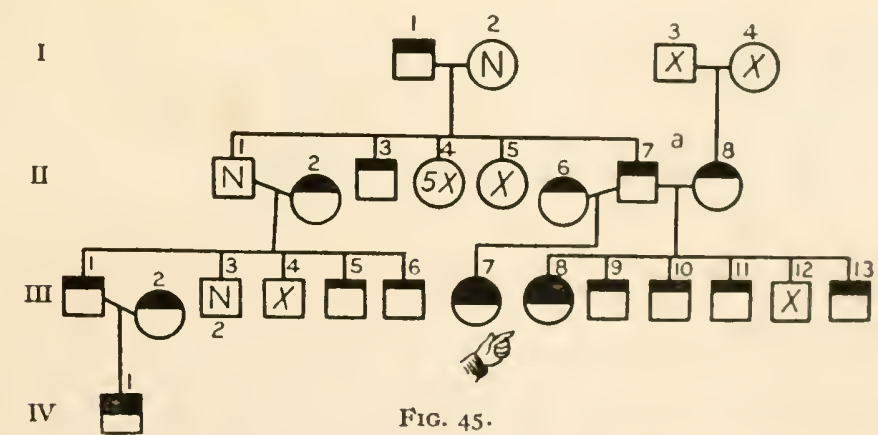

Figure 45--I-I, neurotic, cross, "cranky," and harsh. II-1, happy-go-lucky, not very" ambitious nor energetic. II-2, nervous and energetic. II-3, rather eccentric, very set, suspicions, and ambitious. II-8, cheerful and happy, played jokes on her husband. II-7, peculiar, very suspicious, jealous, and gullible. II -6, irrital)le and peculiar; later became delusional and demented. III-I, temperate, very ambitious. III-2, very eccentric, becane a senile denuent. III-4, very religious. III-5, ambitious and energetic. III-6, energetic, lumorous, and full of fun. III-7, violent-tempered and insane. III-8, always neurotic, suspicious and jealous of her husband; drowned herself. MI-9, went to sea and disappeared. III-10, went 10 California during the "gold fever." III-11, went to California during the gold excitenent. III-12, died in the war. III-13, always cheerful and full of fun and happy-go-luchy, hut alcoholic; at 45 had convulsions for a year. IV-I, had convulsions and hallucinations; hater was violent and homicidal. (25:273.) 


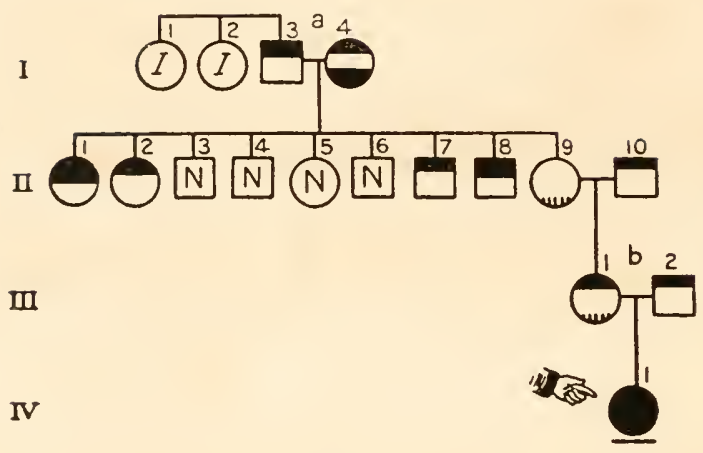

FIG. 46.

FigurE 46.-I-3, rough, gruff; had set ways and peculiar ideas. I-4, nervous, apt to worry (see family $25: 139$ ). II-1, high-tempered, extravagant, became insane and jumped out of window, killing herself. II -2 , energetic and quick. II -7 , odd and eccentric, very critical and miserly, impulsive and irritable. II-8, at 20 became erratic, silly, and irresponsible; wanted to travel and follow girls. II-9, happy-go-lucky. II-10, quick, energetic, and nervous; susceptible to alcohol. III-I, quick, energetic, and nervous. III-2, alcoholic and $S x$; very musical. IV-1, from age of 5 epileptic; at 18 irritable, violent and had hallucinations of a terrifying nature; threatens suicide when depressed. (25:189.)

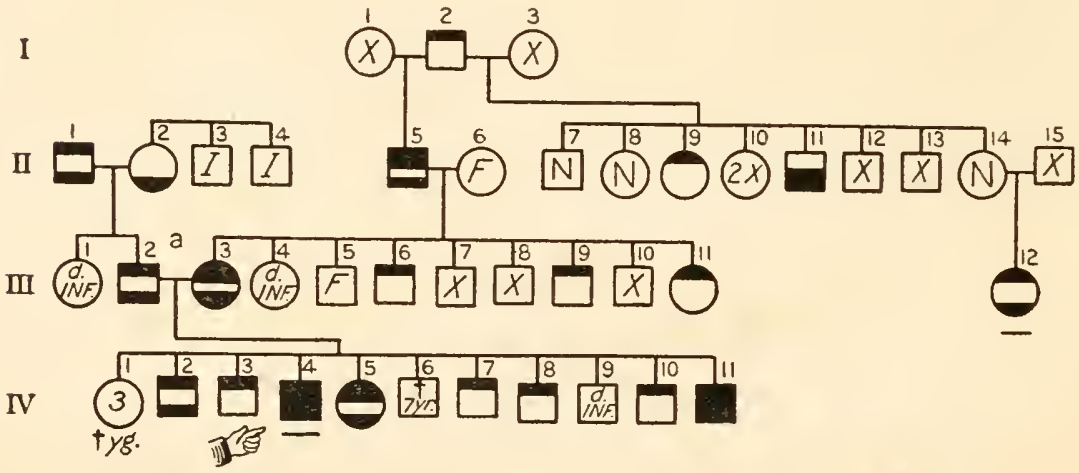

FIG. 47 .

FIGURE 47.-I-2, stern and religious. II-1, rough, alcoholic, and a recluse. II -2 , hallucinated, delusional; disappeared periodically. II-3, 4, committed suicide. II-5, had a periodic, religious mania; was unsocial and suggestible. II -6 , sent her children out to beg. II -7 , of excellent character. II -9 , strong-willed. II-1 I, had nervous prostration and hanged himself. II-12, went West. II-14, of good reputation. III-2, of bad reputation; $S x$, alcoholic, had delirium tremens. III-3, violent-tempered, wildly excitable, $S x$, alcoholic, of low mentality. III-5, shiftless and alcoholic. III-6, alcoholic, of low morals. III-9, alcoholic, $S x$, and a horse-thief. III-1 I, violent-tempered and excitable. III-12, willful, became excited, hallucinated, and talked disorientedly; had severe headaches and a mania for collecting. IV -2 , morose, taciturn, and moody, $S x$, and alcoholic. IV -3 , wild and dissolute; abusive to wife; absorbed in races. IV-4, seclusive; at 29 had persecutory delusions, was suspicious and apprehensive; cut his head and gashed his neck; was hallucinated, homicidal, depressed, and violent. IV $-5, S x$ as a girl; exaggerates, has violent tantrums and headaches; is highstrung and fears insanity. IV-7, of bad reputation and alcoholic. IV -8 , formerly wild and immoral. IV-10, wild and immoral. IV-1I, jealous, violent-tempered, constantly threatened suicide; now broken-spirited and irresponsible. (I 1 : 282.) 


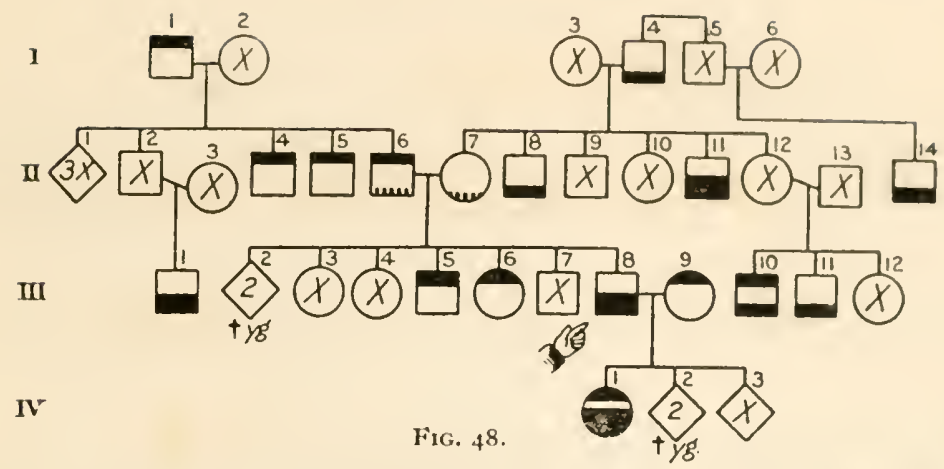

Figure 48.-I-1, had a religious mania. I-4, a senile dement. II-2, successful farmer. III-4. 5. bright and active. II-6, clever politician, keen and level-headed. II- 7 , uf strong character and good intellect. II-8, deeply interested in philosophy. II-9, of strong character and intellect. II -11 , found that his wife was unfaithfu and in consequence committed suicide. II-12, practical and self-sacrificing. II-13, visionary, had strong instinct for taking chances. II-I 4, committed a planned suicide. III-1, gambled; after losses at 38, suicided. III-4, had two attacks of mania and then demented. III-5, alcoholic, intelligent, and shrewd. III-6, "brilliant like her father." III-8, of quiet and studious nature, with periods of surly silence; finally suicided. III-9, lively. III-10, $S x$, killed himself. III-1 1, carried out suicide planned weeks in advance. IV-1, a manic-depressive; has suicidal impulses. (1 i : 148.)

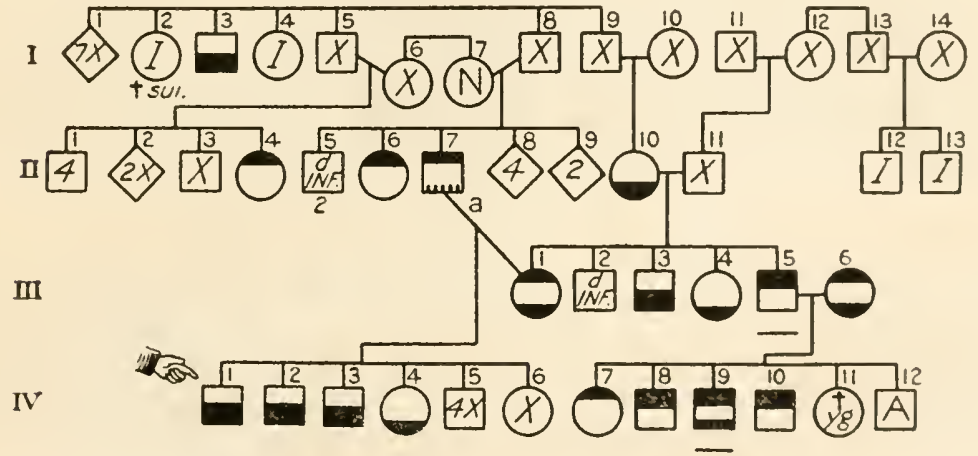

FIG. 49.

FIGURE 49.-I-2, committed suicide. I-3, shocked, he became depressed and hanged himself. I -4 , insane, probably periodically. I -7 , calm and undemonstrative. II -4 , was always highstrung; gained the delusion that her husband would die and drowned herself. II- 6 , nervous, always "on the fly." II -7 , went to California in 1849 but returned. II-10, eccentric; had mute spells. III-x, very nervous, agitated, and eccentric. III-3, depressed and melancholy. III-4, secretive. III-5, had acute mania. III-6, erotic; subject to headaches. IV-I, had depressions and attempted suicide by cutting his throat. IV -2 , had depressions. IV -3. depressed; attempted suicide. IV-4, had severe headaches. IV-7, irritable and unreasonable. IV-8, lively, pleasant, and sociable, but alcoholic; finally cut his throat. IV-9, a manic-depressive. IV-10, died at 21 with acute mania. $(12: 228$.)

FigURE 50.-I-I. shiftless and hypochondriacal. I-2, healthy and industrious, but inclined to worry. I-3, temperate; had a mental disturbance for 2 months in middle life. I-4. insane at 47 ; despondent and apprehensive. II $-2,3$, went West wlien young. II-4, inclined to worry and fret; naturally moody and pessimistic. II-5. genial but excited in conversation. II-7, somewhat alcoholic. II-8, temperate, 111social; has a poor menory. II-9, irritahle, decidedly nervous, restless, not coöperative. II-10, of goud habits. II-I 1, twice insane; more nervous than II-9. II-12, had no mental trouble, but "worked herself to deatl." II-13, at 27 had acute mania; was subject to sick headaclies; became restless, confused, and disturbed. II-15, worries easily, but is industrious and capable. II-16, went West. II-17, divorced; 


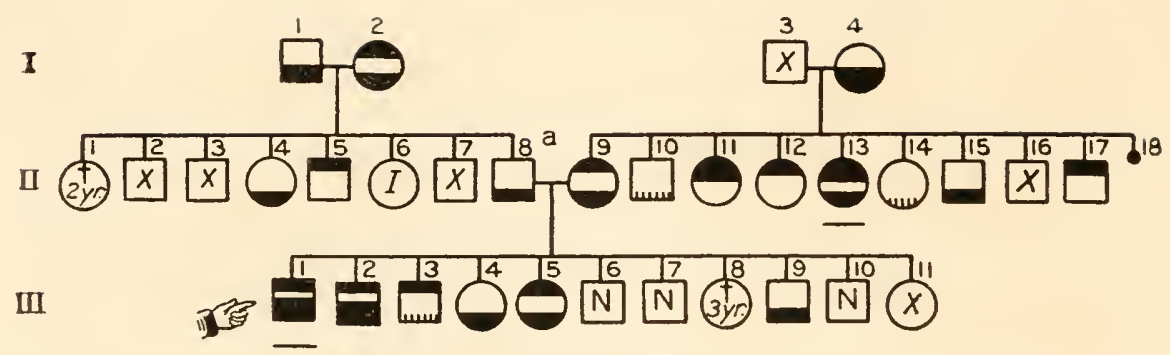

Fig. 50.

FigURE 5O-continued.

goes from one occupation to another. III-r, from 14 to 19 had flighty spells; at 35 was depressed; had many hypochondriacal periods and became very depressed, when he attempted suicide. III -2 , subject to dizzy spells; sometimes drank to excess; died suddenly at 27 by poisoning (coroner's inquest). III -3 , nervous, peculiar, quick-tempered. III-4. has neuralgia frequently. III-5, excitable and irritable; fretful. III-9. subject to dizzy spells and headache; hypochondriacal. III -10 , of good health and habits. (28:933.)

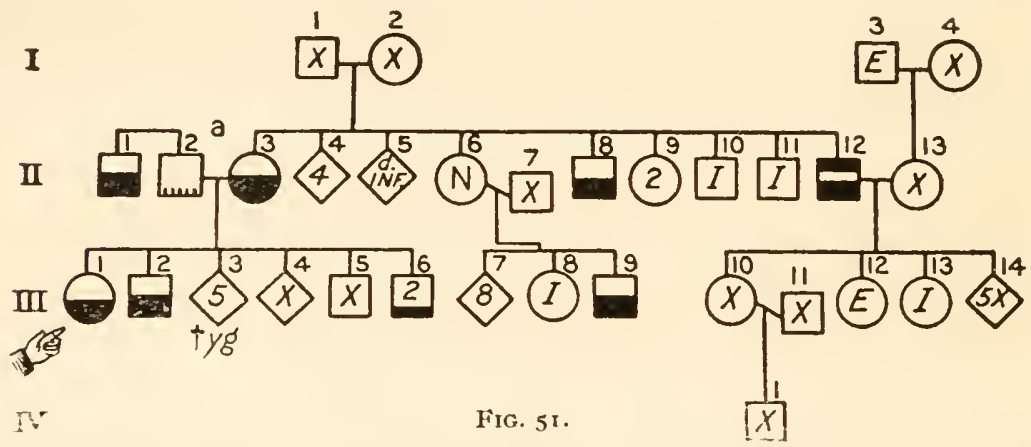

FIgURE 5x.-II-1, very melancholy; hanged himself. II-2, clieerful. II-3, hypochondriacal. II-8, alcoholic; had a periodic psychosis; in a depression he hanged himself. II -10 , had the impulse to hang himself. II-11, liked to torture animals. II -12 , prominent in church and temperance work; in a depression he cut his throat. III-1, melancholic; became insane; set fire to her clothes and burned to death. III-2, melancholy; shot himself and jumped into a well. III-6, little known; nervous trouble denied. III-9, after a love affair committed suicide. III-12, also insane. IV-I, attempted suicide. (18:171.)

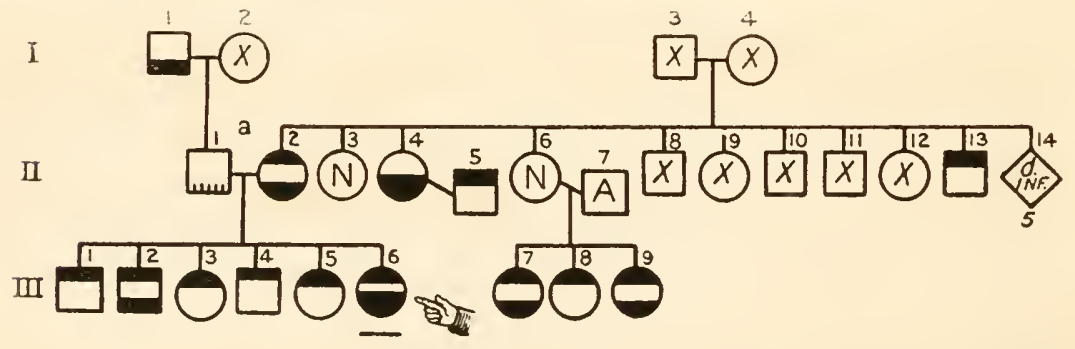

FIG. 52 .

Froure 52.-I-I, worried. II- 1 , alcoholic in middle life. II-2, nervous, upset, irritable in pregnancy; in later life cheerful and sweet-minded. II-4, melancholic on account of husband. II-5, "sprees." II -6 , mild and calm. II-13, has nervous movements; is a traveling salesman. III-I, alcoholic; a "fly-away talker." III-2, bites his finger-nails and twitches. III-3, excitable. III-4, bites his finger-nails. III-5, nervous. III-6, takes small troubles seriously; worried; talked of suicide; at clinic, now the picture of despair and then laughing and cheerful. III-7, extremely nervous; "twitches;" would not go out alone. III-8, domineering and "cranky." III-9, shook as she walked; inclined to worry. (40:764.) 


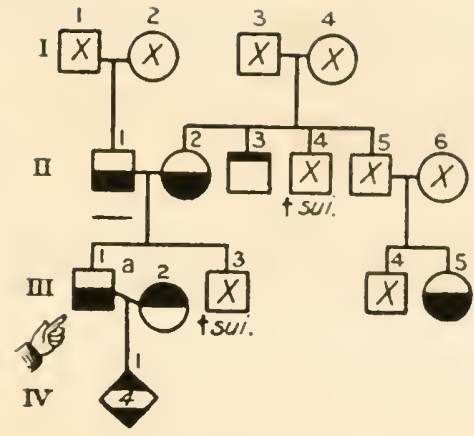

Fic. 53

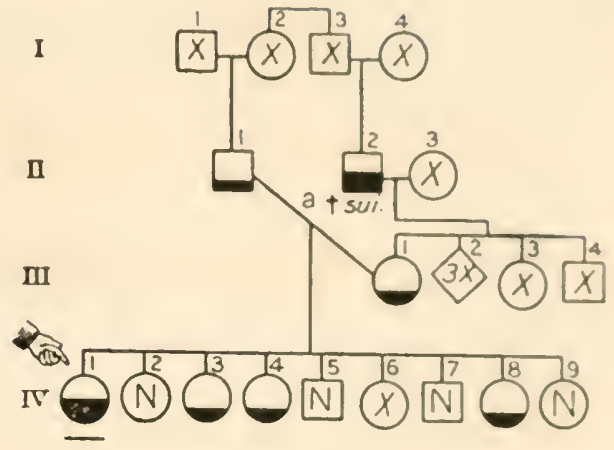

Fic. 54 .

Figure 53.-I-2, of Indian descent. II-1, attempted suicide at hospital. II-2, alcempted suicide. II-3, eccentric and stingy, II-4, hanged himself. III-1, melancholy; worried; hypochondriacal; hanged himself. III-2, highly neurotic. III-3, committed suicide. III-4, in forest service. III-5, melancholy, twice insane from strain of teaching. IV-I, four children, all highstrung. (43:159.)

FigurE 54.-I-1, sensible and with good mind. I-2, hright; great worker. 1I-1, took to drinking; would not talk; died of paretic dementia. 1I-2, at 65 had softening of brain, became restless, worried, hanged himself at $7 \mathrm{r}$. III-1, pleasant, hal neuritis so badly that she screamed frightfully. III-3, 4, nervous. IV-1, every little thing worried her; at 28 became suspicious, sensitive, seclusive. Had ovaries removed; lecame desperately nervous; screamed and cried, jumped at least noise; changeable in mood; worried and was depressed. IV -3 , nervous. IV-4, rather nervous. IV -5 , thouglatful and conscientious. IV-6, bright, happy girl. IV-8, somewhat distant. (40:625.)

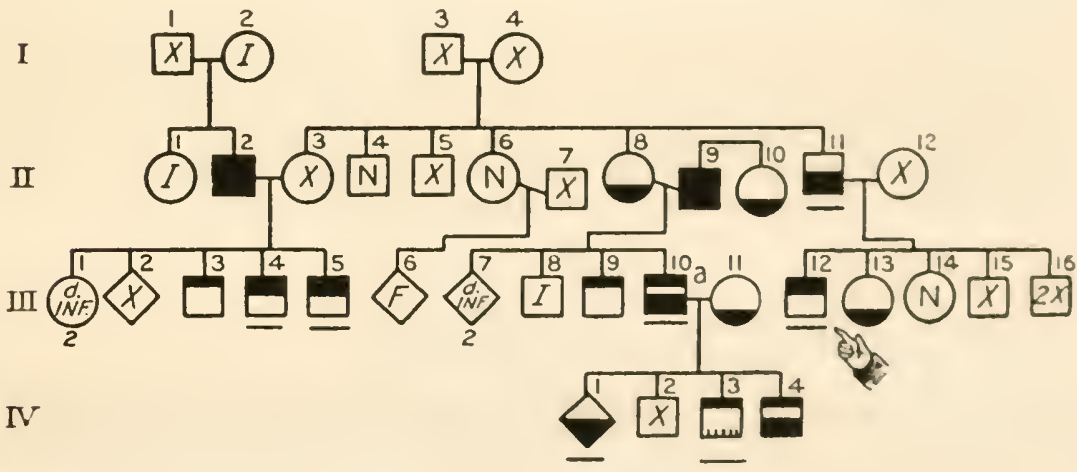

Fitg. 55 .

Figures 55.-II-2, had a violent temper and spells of (lepression. II-6. "smart." II s. subjece to migraine and fainting spells. II - o, had alternate perixls of depression and excitement. hanged himself. II-10, lad depressed spells. II 11, had periodic atlacks of depression; hanged himself. III-3. has delusions of importance; is ponpous. III \&. had acule mania; now deteriorating. III-5, sticidal and homicidal; cut his throut hut not fatrly; demented. 11I-9, said to be normal (queer). HI - 10 , excited, dangerous, suiciblal; later depressed: probably an epileptic. III-11, neurotic; subject (1) headacles. III 12, maniacal and homicidal. III-13, had depressed spells. III-14. well balanced and capable. III-IS. queer. IV-1, became depressed and demented. IV 2 , constitutionally inferior. IV-3, had violent fits of temper and dreamy states; wis restless; had delusions and hallucinations. IV-4, at 32 was suicidal and lad attacks of latughing and crying. (38. 6.) 
FIgure 56.-I-3, went West. II-1, alert, active; has a good memory. II-2, went West. II-4, quiet and subservient to his wife; troubles weigh heavily upon him. II-5, irritable, excitable, domineering, and suspicious, violently jealous; suffers from severe headaches; comes of very neurotic and neuropathic stock. III-1, queer. III-2, worried, had mental breakdown; became suicidal and very depressed. III-3, worried, became depressed,

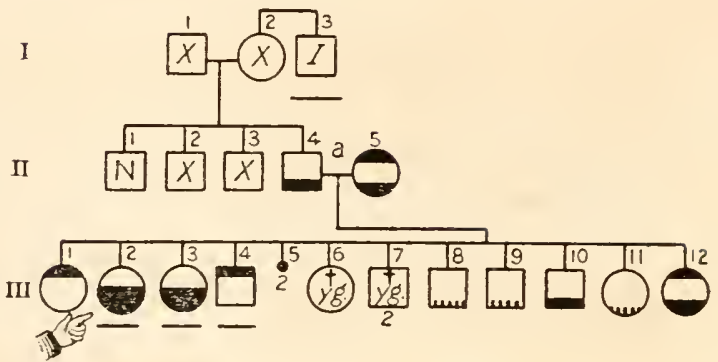

Fig. 56 . had hallucinations. III-4, on skull being fractured became violent; dementia precox. III-10, markedly negativistic. III-12, nervous and hysterical; has weeping spells. $(13: 39$.

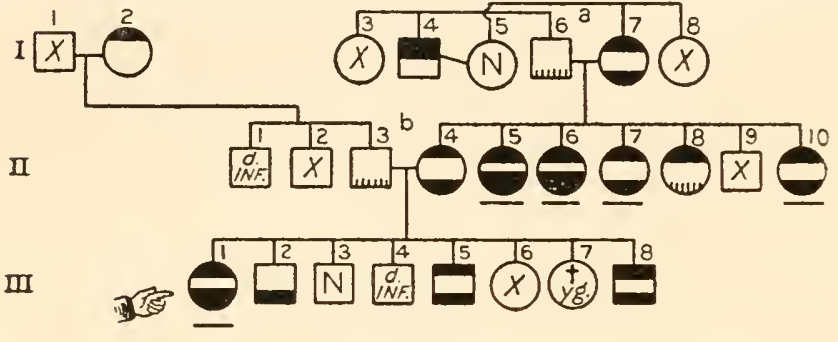

Fì. 57

FIGURE $57,-$ I-I, quick, energetic, bright, sunny, and never moody. I-4, suspicious, alcoholic, violent, brutal; killed his wife. I-5, bright and sunny. I-6, mild, easygoing, and goodtem pered. I-7, said to be quiet, helpful, and not easily angered. I-8, of a sunny disposition. II-3, quiet, gentle, sober; had no temper. II-4, full of fun and good-natured; worried some, but was never depressed. II-5, at 59 became hyperactive, noisy; demented and later became depressed. II-6, had delusions at 37 ; if disturbed is irritable, angry, scolds, and threatens violence; at times sits quietly and is disinclined to answer questions; is deteriorating. II-7, excitable; scolded; now seclusive and seldom speaks. II-8, hot-tempered. II-9, alcoholic. II-IO, at 38 became noisy and excitable; swore; had delusions of grandeur and became demented, and partly mute. III-I, worried; had a wandering mania; at 34 had hallucinations and was depressed; had delusions, was hypochondriacal, and wished to die. III-2, of melancholy mien; given to worry, but was even-tempered, happy, and cheerful. III-3, kindly, conversational; loves flowers; has a gentle humor. III-5, wild and given to drink; died at 28 . III-6, very peculiar; died at 22 . III-8, a dipsomaniac; irritable, quick-tempered, impetuous, sullen, morose, and easily excited. $(22: 42$.

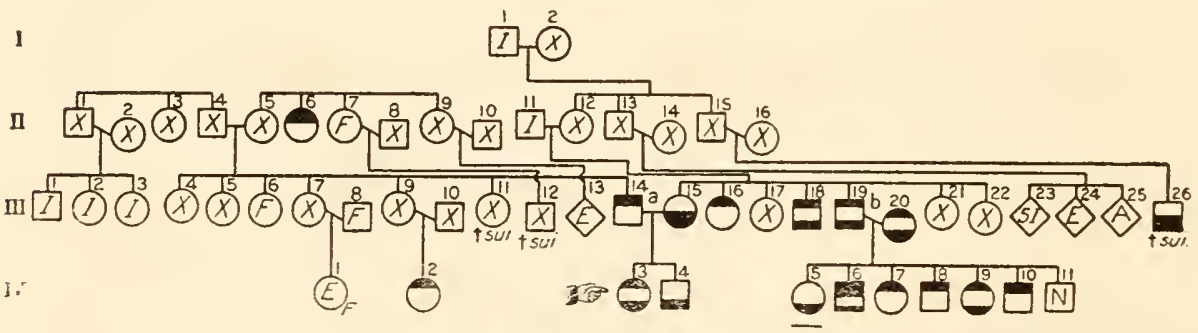

FIG. 58 .

FIGURI: 58.-I-1, periodic insanity. II-3, very nervous. II -4 , died of apoplexy. II-6, insane and homicidal. II -7 , insane. II -1 , periodic insanity. III-1, alcoholic at times; insane for a month. III-2, insane several months. III-3, insane at climacteric. III-4, has queer streaks. III-5, half-balanced. III-11, committed suicide by burning herself to death. III-12, hung himself. III-14, alcoholic, harsh, disagreeable; abused his wife. III-15. melancholy. III-16, very eccentric. III-I7, queer. III-I8, alcoholic; worries; is loquacious. III-19, nervous, worried, alcoholic, ugly-tempered. III-20, good-natured, cheerful. but liad depressed spell. III-2I, a little queer. III-26, committed suicide in a fit of despondency after adultery. IV-1, feeble-minded. IV-2, hyperactive. IV $-3, S x$ at 30 , now 
FIgURe 58-continued.

quiet again. IV-4, feeble-minded, peculiar, quiet, unsocial, and saving. IV-5, reserved and unsocial. IV-6, high-tempered, ngly, assaultive. IV-7, Sx, eccerzicic IV-8, even. tempered, but destructive and alcoholic. IV $-9, S x$ and morose. IV-10, high-tempered and alcoholic. IV-II, "best of the boy"s so far." (7: 15.3.)

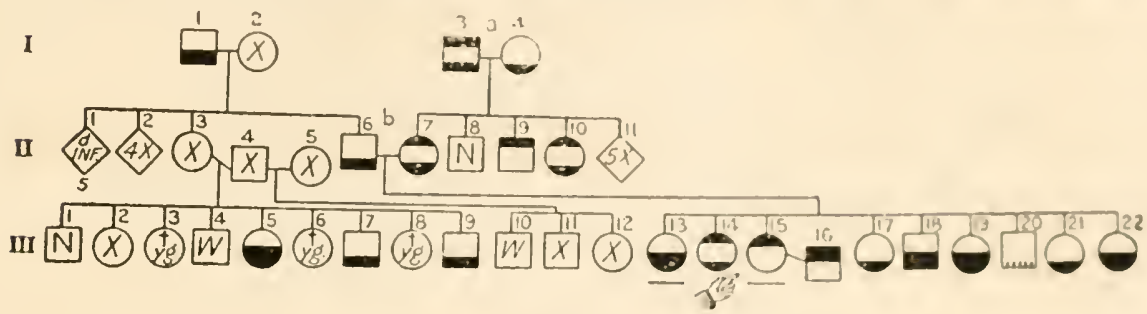

FIG. 59.

Figuris 59.-I-1, had melancholy spells. I-2, died senile. I-3, showed temper when drunk later wept over his misdeeds. I-4. sweet and lovable; dicd of "grief." II-3, childish in old age. II-6, at 60 stopped work, saw no one, expressed desire to commit suicile. 11-7, had headaches; optimistic, amiable, worried noderately. 1I-8, of even dispositiun. 1I-s of even disposition but had a little temper. II-10, somewhat lively, but more or less sad. III-1, friendly and agrecable. III-4, "knocks about." III-5, hright, bites nails, cries bitterly, worries, wishes to die, tried to commit suicide; homicidal. III-7, twice depresser]. III-9, mental processes slow. III-II, shiftless, grew worse. 1II-13, at 20, 25, and 30 had disturbed periods, being very religious; at 43 became melancholy and lost interest. $111-14$ was very religious; at 33 committed suicide by taking carbolic acid. III-15, happy, cheerful and sociable; contemplated suicide with carbolic acid; now recovered. III-16, Sx; committed suicide. III-I7, weekly sick headaches; fears mental trouble. III-18, two marked depressions of religious nature. III-19. depressed for 9 inuntlis; has frequent nervous spells. III-20, successful. III-21, looks worried. 1II-22, cross at times; gets melancholy for brief periods; has sick headaches. (40:514.)

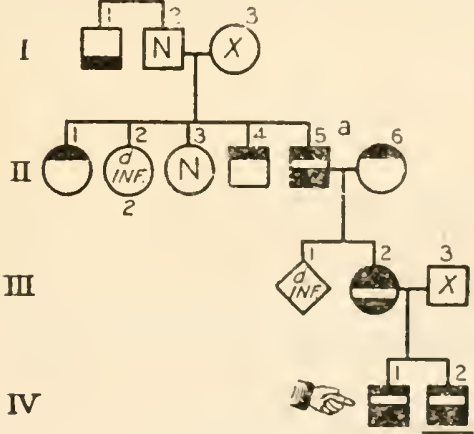

Fig. 60.

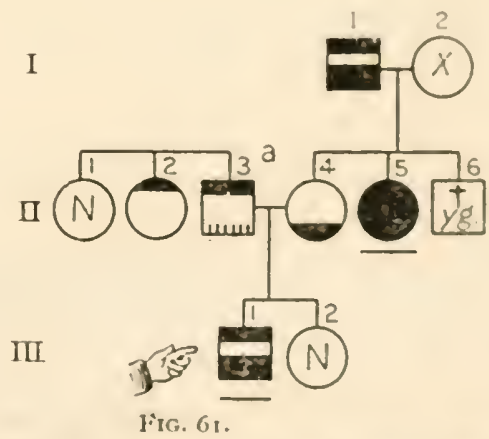

Fig. 61.

Figure 6o.-I-I, depressed; at so committed suicide. II-1, happy, jovial, never worricl. II-4, bright; expelled from school; became governor of a western Siate. II-5. Sx; looked on the dark side; had periods of depression and committed suicite hy shooting. 11-6. eccentric. III-2,S.x, bad-temperel, lazy, and shiftless. IV-1, laad sjells of depression and sadness; $S x$, quarreled with his wife; had no foresiglnt; at 50 shot himself. IV-2, seclusive, $S x$; at 44 acted queerly, hecame dejected and worried; delusiunal; nt is attempted suicide by shooting, and at Go suicided with poisurt. ( $11: 59$ )

Figure 61.-I-1, socialble and jovial, hut worried and grew depressed; at $(r)$ eommitted suicide by drowning. II-1, 5, girls, were sociable aud well liked. II-2, a fussy, puttering old lady; irritahle and disagreeahle. II-3, sociahle, cheerful, and even-lempered. II-4. scelusive and inclined to worry, but even-tempered and well liked. II - s, seclusive, irritalile, and peevish; at 19 was noisy and excited. later depressed; at hospital 3 times for nuasia and depression. IIl-I, stubborn, opinionated; spent niglits in earousals and delancheries; became irritable and threatening; law epileptic fits, then periods of restlessness nnd depres. sion. (4I:37,3). 


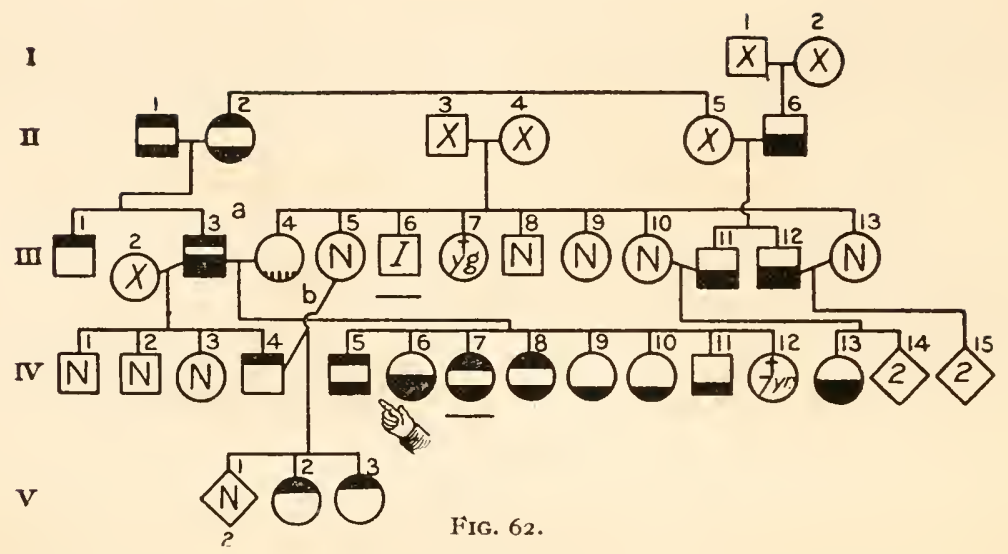

FIGURE 62.-I-2, curious about others' business. II-I, jovial and fond of jokes, but later crabbed, erratic, and hard to get along with. II-2, serious, proud, and strong-willed. II-3, childish before death. II-5, now senile. II 6 , at 55 bccame melancholy, rambled about, died from a dose of poisoning. III-I, jovial and easy-going, an "odd genius." III-3, serious, sensitive, sad; after drinking became profoundly depressed and threatened suicide; in old age was crabbed, erratic, and hard to get along with. III-4, sensible, not a worrier. III-5, kind, easy-going, and lovable. III-11, insanely jealous of his wife; has melancholia. III-I2, has impulsions to suicide. IV-4, nervous, fussing, quick-tempered. IV-5, naturally happy; had impulsions that he feared; hung himself. IV -6 , nervous and subject to depression and melancholia, but had never shown elation. IV-7, shy, stammering, and bashful; at 2.3 her love being unrequited, she became suddenly excited, violent, and assaultive; is deteriorating. IV-8, subject to impulsions of suicide. IV-9, cheerful, but loses emotional stability. IV-ro, cheerful, sociable, and happy, but very serious-minded. IV-1I, nervous, serious-minded, emotionally pessimistic. IV-1,3, had depressions with terror. $\mathrm{V}-2$, is developing a religious mania; naturally quict. $\mathrm{V}-3$, obstinate. (45: 115.$)$

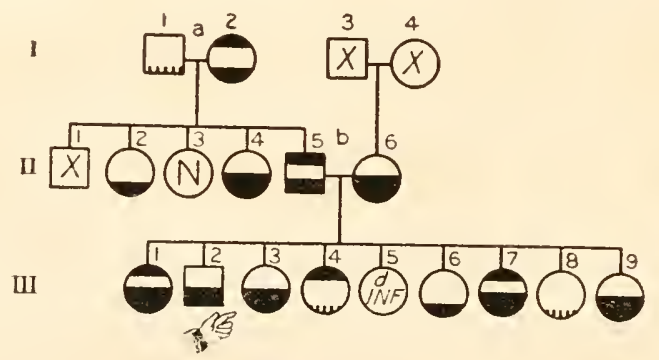

Fig. 63.

FIGURE 63.-I-I, mild, kind, and well thought of. I-2, refused to speak to her husband for days; always highstrung and awfully nervous. I-3, exceptionally shy. II-2, "odd and quiet." II-4, has involutional melancholia. II-5, "hard-tempered," nervous, and highstrung, $S x$. II-6, worried; had severe headaches; was insane for a time. III-1, hysterical, hyper-religious, excitable, depressed. III-2, at 45 became depressed; had hallucinations; later said he was going to kill himself. III-3, had numb spells; in deep melancholy hanged herself at 35. III-4, jolly, sociable, and easy-going; had terrible headaches; became hallucinated and delusional. III-6, neurasthenic. III-7, excitable, has had sick headaches; had 2 depressions. III-8, "more like other people." III-9, depressed for months. (12:113.) 


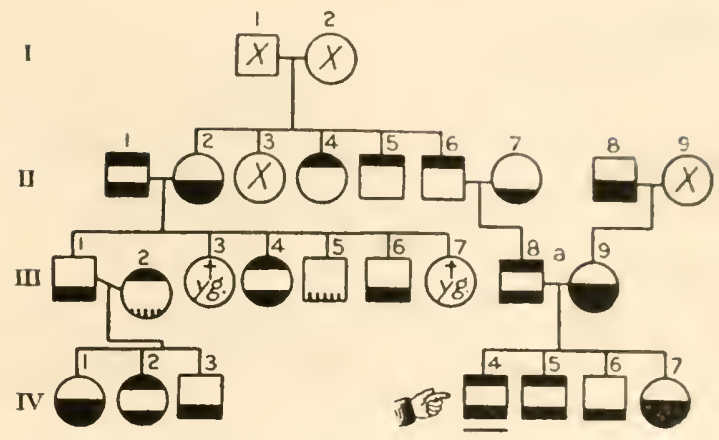

1.15. 6.4.

FiguRE: 64--II-1, of highly nervous temperament; had a religious mania. II- 2 , even-tempered; starved herself to death. II-3, great church womau. II -4 , ugly-tempered. II-5, alcoholic; had a temper. II-6, had an easily aroused, bad temper. II-7, easy-going, swcet, mild, and gentle, but over-conscientious. II-8, died by suicide by cutting his throat. II-9, healthy. III-1, even-tempered; had neuralgia. III-2, nervous. III-4, of a lighlly nervous temperament, but very intelligent. III-5, of a quiet disposition; dropped dead at 37 . II I-6, quiet and worried much. III-8, hasty-tempered, reserved; a dipsonaniac. III-9, had periudic headaches; was always nervous, worried much; "breaks down" at thought of her son. IV-r, musical; was religiously worried and died of acute melancholia. IV-2, had severe monthly headaches; was excited at other times. IV -3 , has nerve exhaustion. IV-4, morbid, sensitive, did not react quickly from discouragements; wandered away; at 20 became wild and excited; later picked his skin; at 26 excited and ugly. IV-5, gets depressed but reacts quickly. IV-6, has headaches and bilious attacks. IV-7, convulsions while teething; hypochondriacal, melancholy, and delusional about husband's death. (22:74.)

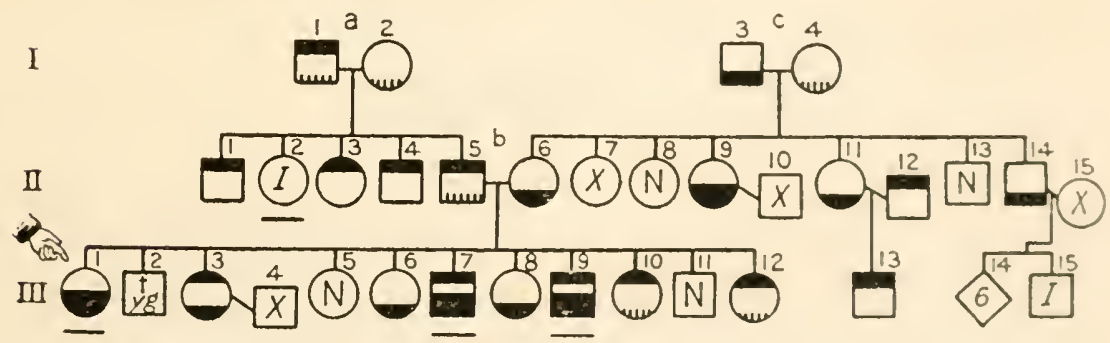

Fic. 65 .

FIGURI 65.-I-I, a periodic drinker, quick-tempered. I-2, healthy, of a kindly disposition. I-3, of a quiet, mild disjosition. I- , a gentle, kindiy woman. 11-1, has wanderlust; is jolly, cheerful, and sociable. II-3, jolly, full of fun, and sociable. II-4, quick-tempered; dipsomaniac. II-5, excitable and quick-tempered; drank sone. II-6, inclinel to worry; would break down and cry. II-8, jolly and sociable. II-9, remorseful; drowned herself at 24. 11-11, nervous, a worrier. II-12, nervous. II-13, pleasant and clicerful. II-14. delusional before death. II -15 , hind and cordial. III-1, al 31 becanse restless und sleepless; secmed dull and listless; desperate; had suicidal and homicidal impulses. 111-3, easygoing and even-tempered, but restless and nervous; had 12 miscarriages. III-5, cheerful and well. III-6, sociable, but "touchy:" III-7, seclusive; at 25 was hyjxoliondriacal; hinted at suicide; was melancholy and ha!lucinated; at 26 suddenly becane excited, irrilable, and impulsive. III-8, sociable and cleerful, but inclined to worry. III-4), quick-tempered: had periods of excitement; became hallucimated, then restless and depressed; made impulsive assaults. III-10, quick-tenpered and excitable. III-12, quick-tamperel. III-1,3. aleoholic and dissipated. III-15, dementia precox. (45:210.) 


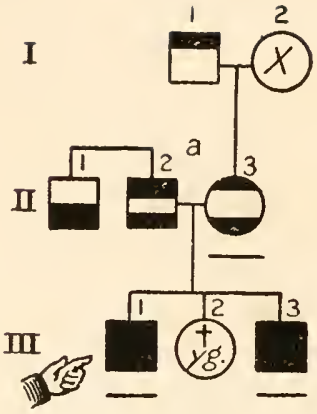

FIG. 66.

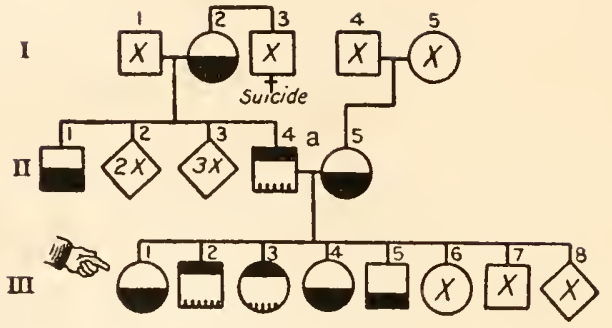

FIG. 67.

FigURE 66.-I-I, hot-tempered. II-1, very depressed. II-2, at 15 showed religious excitement and became violent. II -3 , delusional. III- 1 , at 21 had religious mania; at tempted suicide; had delusions of sinfulness and grew depressed and silent; later became excited and restless and had delusions of persecution. III-3, had delusions of persecution and at tempted suicide; became excited, emotional, and worried. (28:25.)

Figure 67.-I-2, had delusions of poverty and hanged lierself. I-3, committed suicide. II-1, had periods of melancholy and depression and had delusions of poverty. II-4, merry, good-natured man. II -5 , at 16 had period of despondency. III-1, had mental trouble and attempted to burn her home. III -2 , ran away and died in the war. III-3, energetic. III-4. depressed at menopause; attempted to drown herself. II $[-5$, inclined to worry. (28: 20.)

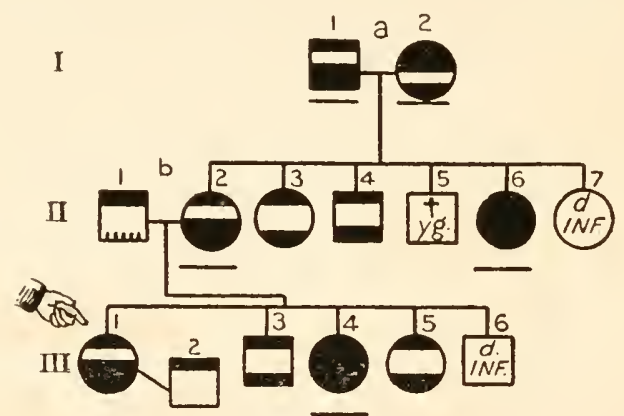

Fig. 68.

FIGURE 68.-I-1, became depressed and died a senile dement. I-2, became unsocial and developed delusions of persecution and fire; was high-tempered, excited, and obscene. II-I, a good, religious man, but not very successful. II-2, was nervous, irritable, and uncontrolled; became depressed and melancholy, fearful and suspicious; now over-sensitive, suspicious, seclusive, and at times depressed. II-3, slightly nervous. II-4, nervous and irritable. II-6, quick-tempered, unruly; developed delusions of persecution; at 32 smashed furniture, was restless, noisy, and talkative; later had melancholia. III-I, of a sweet disposition; had nervous tics and painful menstruation; was musical and artistic; became depressed at 25 and shot herself. III-2, a hard husband; determined in his ways. III-3, gets blue and depressed; worries; cares stick to him. III-4, at 16 a fright suppressed her menses and she became hysterical and excited and then alternately depressed and excited; had delusions of persecution and was erotic. III-5, unstable in mood; gushing, vivacious; a moral imbecile. (21:215.)

Figure 69.-I-1, nervous, lazy, selfish, and extremely irritable. I-2, at 34 had melancholia, was easily discouraged and depressed; at 37 and 45 had other attacks; cried; liad delusions. II-I, constitutionally inferior; at 5 I tried to commit suicide; had acute melancholia; had delusions. II-5, at 35 had melancholia and increased attacks at 41 and 55; became religiously agitated, excited, delusional, and had sticidal tendencies.

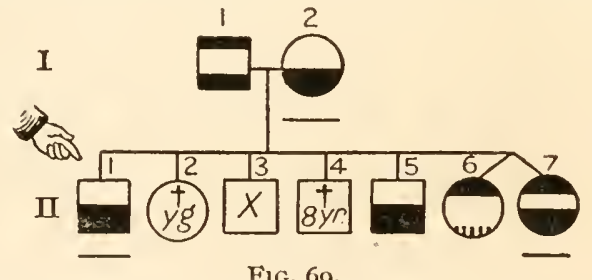

F1G. 69. II-6, a moral imbecile; $S x$, irritable, determined, and nervous. II-7, became hysterical, depressed, hypochondriacal and hallucinated. (21:262.) 


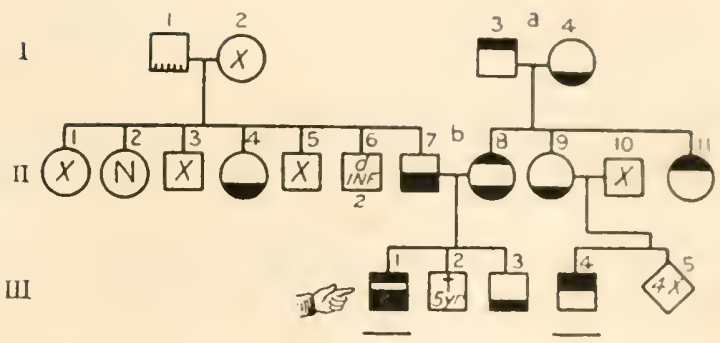

Fig. 70 .

FIgURE 70.-I-I, sociable, respected, and well liked. I-3, active, ambitious, sociable, and well liked. I-4, sociable, though quiet, retiring, sensitive, conscientious, and devout. II-2. sociable and lovable; had high standards. II-4, quiet and retiring, reserved and " peculiar." II -7 , in middle life became melancholy, lost interest, became seclusive, then demented and was childish and irritable. II-8, a general favorite, but sensitive and a worrier. II-9. ambitious, sociable, but sensitive and a worrier; had nervous prostration and insomnia. II-Ix, at 12 had brain fever; became an imbecile; easily irritated. III-1, committed to State hospital; at 12 had periodic spells of excitement and exhilaration and depression; at $4^{1}$ attempted suicide by cutting his throat. IV-3, sociable, well liked, sympathetic, optimistic, and gentle. IV -4 , at 4 indressed in public and set fires. $(41: 380$.

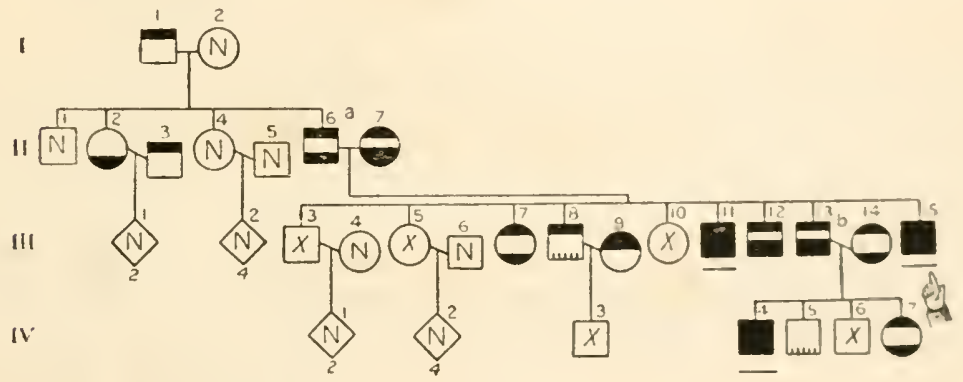

FIG. 71 .

FigurE 71.-I-1, cheerful and energetic. I-2, capable tnentally. 1I-2, looked on the dark side and worried over religious matters. II-3, of a jovial disposition, but a cheat. 1I-4, cheerful and capable. II-6, strong-willed, stern but gentle, quiet, reserved, anul religious. II-7, excitable; became depressed and threatened suicide; had alternating moods. III-3, well and capable. III-5, capable and well. III-7, nervous, excitahle, disposed to worry and be apprehensive. III-8, musical and poetical. III-9, had fits of excifement and violence. III-10, capable mentally. III-I I, inusical, sociable; at 29 developed delusions of persecution; was alternately depressed and excited, suicidal and then later delusional. III-12, musical, active; is now beconning depressed. III-13, nervous, anbitious, easily disconraged; h.ld periodic depressions and lecame suicidal; now is cheerful. 1II-14, nervous and irritable. III-15, at 23 became depressed and suicidal; later excited and suicidal; at 42 had severe headaches. IV -3 , a fine harpist. IV -4 , had alternating depression and excitement; luter hallucinations and delusions of persecution; once slowed tlexibilitas cerea; at 17 aduitted to the hospital; later became jovial and was discluarged; at in was ugain admitterl, being violent and sullen, but later became cheerful; had strong suicidal tendencies; is at times talkative, threatening. profane, and obscene; had threatened the life of his parents; at 27 attempted suicide by strangulation. IV -5 , of an easy-going, cheerful disposition. IV- - in youth had a nervous breakdown; now cheerful and very capable. $(44: 4.35)$ 


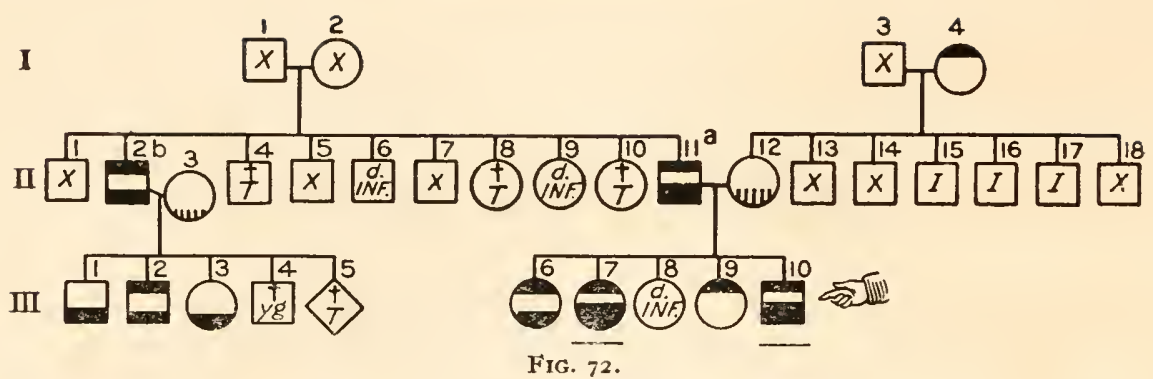

FIgURE 72.-I-2, quiet and pleasant, but now a senile dement. I-3, fell dead from dropsy. I-4, jolly; a great reader. II-I, disappeared from home. II-2, nervous and irritable, had delusions of poisoning. II -3 , of a quiet nature. II-5, finding wife untrue, he went West. II-I I, jolly and active; sunstroke said to have caused delirium and he cut his throat. II-12, cheerful and happy. II-15, alcoholic insanity. III-I, had tuberculosis; worried and died insane. III-2, worried in spells and became excitable and insane. III-3, had severe headaches. III-6, under heavy strain wore out, but is dignified and pleasant; has trembling in lower part of face. III-7, disappointed in love, had deep melancholia, wished to kill herself; had headache and dizzy spells; became very depressed and demented. III-9, of a happy. cheerful nature, fond of joking; knowledge of relatives kept from her. III-10, at 25 was depressed and hallucinated; later had suicidal tendencies, inclined to wander; now is excitable and restless, has delusions of persecution, and is sometimes depressed. $(22: 118$.)

FIgURE 73.-I-I, Threw himself down a well in a fit of acute mania II-2, nervous. III-I, inventive, nervous, eccentric; had nervous breakdown and became vulgar, restless, melancholy, and elated. III-2, nervous, quick-tempered, impulsive, calms down to her usual happy state; never depressed. IV-I, moody and crratic, stubborn, impulsive, hot-tempered, but happy; at about 30 became depressed; later attempted suicide by shooting; now depressed. IV-2, always nervous; at 19 became hysterical and destructive; at 21 had another at tack; at 24 attempted suicide by jumping into the river; is now noisy, delusional, irritable, and talks wildly. IV-3, always nervous; at 32 became maniacal at childbirth. $(56: 40$.

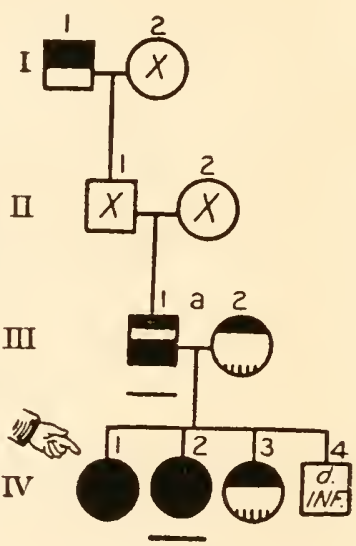

Fig. 73 .

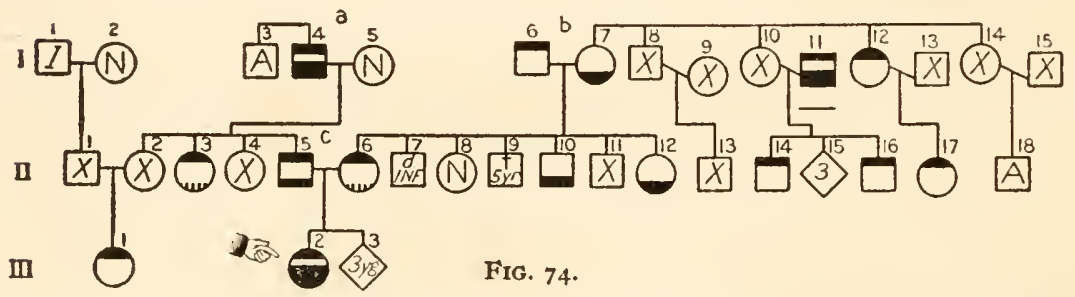

FIgURE 74.-I-4, Sx; became depressed and committed suicide at $65.1-5$, even-tempered. I-6, musical. I-7, had nervous trouble at childbirth; now paralyzed; at 74 had visual and auditory hallucinations. I-1 I, had uncontrollable eroticism and became delusional; diagnosis, melancholia. I-12, musical; $S x$. II-3, an excessive talker. II-5, alcoholic; had so violent a temper that it endangered the life of the offender. II- 6 , musical; flighty in conversation. II-10, had a nervous breakdown. II-12, very intellectual; at 40 had delusions of persecution. II-13, a spccialist in nervous diseases. II-14, Sx. II-16, $S x$. II-17, $S x$. II-18, alcoholic; an inventor of note. III-1, very excitable. III-2, at 16 became depressed and then excited; hyper-erotic; probably had manic-depressive insanity. $(13: 97$. 


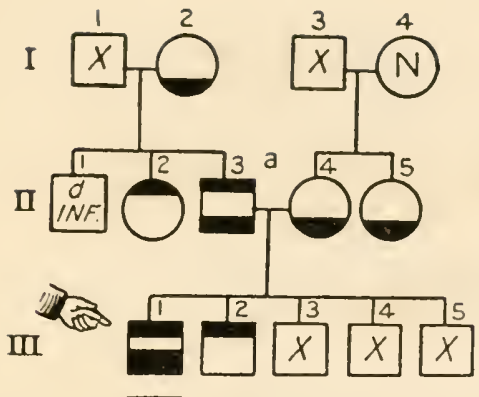

I'1G. 75 .

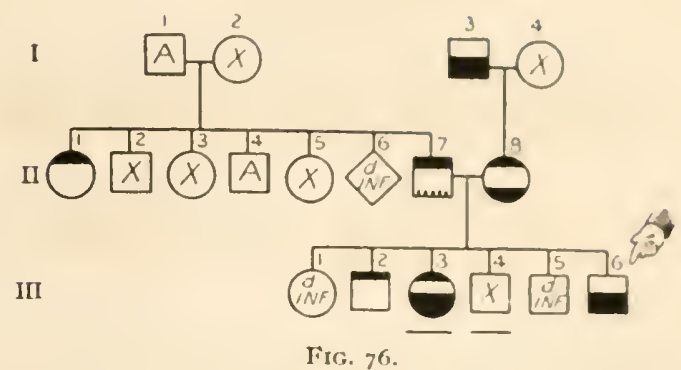

FrguRIs 75.-I-2, inclined to worry. I-4, well and mentally capable. II-2, always peculiar and eccentric; later was at times violent. II-3, traveling salesnan; highstrung, irritable; a worrier. II-4, had neuralgia and sick headaclses; nervous in manner. II-5, yuiet and slow. III-I, restless, depressed; threatened suicide; was delusional and hallucinated; later excited and hysterical. III-2, of a roving disposition. III-5. quick and intelligent. $(44: 288$.

FIgURE 76.-I-I, a drunkard. I-3, subject to deep depressions. II-I, an actress of good character. II -4 , of low repute. II $-7, S x$; a periodic drinker. II -8 , very susceptible to beauty and loved pretty clothes; ran away with another man. III-2, wild in youth. III-3. has periodic attacks of temper and afterwards broods; is suspicious and melancholy; likes to act, when she becomes quiet and affectionate. III-4, would wander around stealing. III-6, became morbid at 16 and drowned himself. $(9: 257$.

FIGURE 77.-I-2, died of worry. II-2, died of worry at 25 . III-2, respected; fond of his children. Says there is nervousness in his family. III-3, a worrier; had melancholia and hysteria. III-5, very excitable. III-6, died of brain trouble. IV -1 , gentle and controlled as a girl but became obstinate, disagreeable, melancholy and hypochondriacal; later was delusional. IV $-2, S x$; forged check; attempted suicide. IV -3 , at 16 eloped and married unhappily; tried to commit suicide; had melancholia; became $S x$. IV-4, wild and $S x$. IV -5 , seems steady. IV-6-8, young. (34:161.)

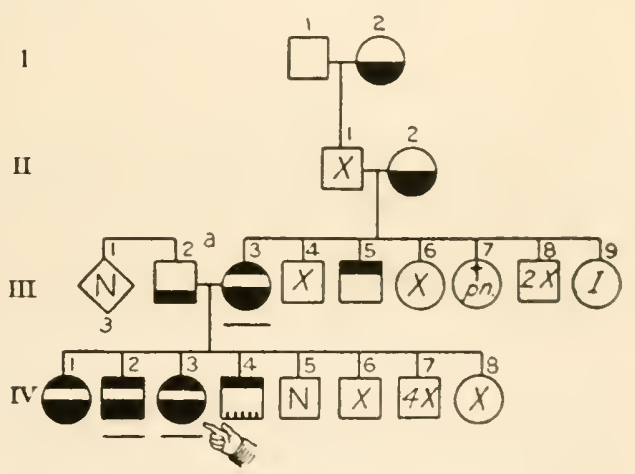

FIG. 77 .

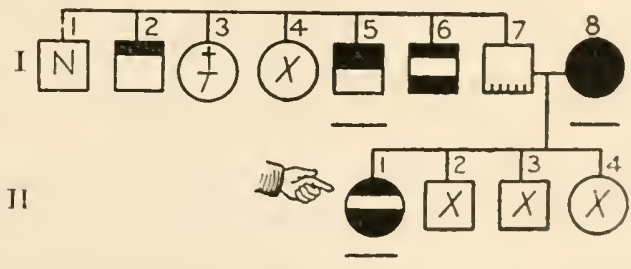

FIg. 78 .

FIGURE 78.-I-2, childish and irritable before death at 84. I -5, at 31 delusional, destructive and hallucinated. I-6, fidgety, fussy and irritable; inclined to worry. I-7, considered sound mentally. I -8 , at 45 noisy, excitable, destructive; after sjell of low spirits committed suicide at 50; diagnosis, chronic mania. II-1, at 32 was worried anel cmotional when admitted to hospital; then, quiet and orderly; later was disturhed and laughed much; committed suicide. $(28: 1689$. 


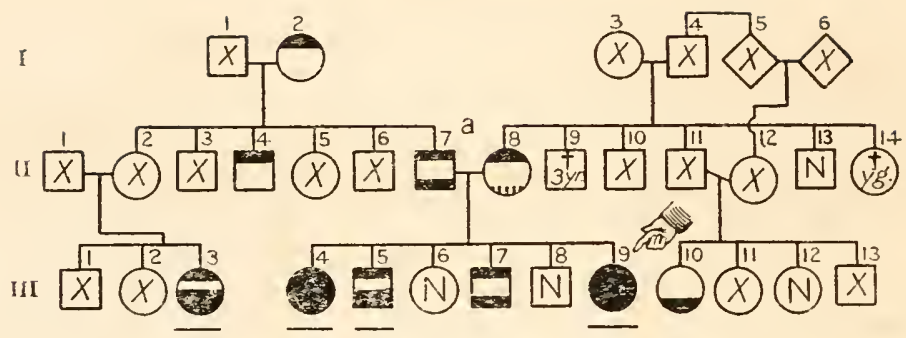

Fig. 79 .

FIGURE 79.-I-I, of even, sympathetic disposition; became childish. I-2, energetic, capable, alert, sociable. I-3, died of softening of brain. II-I, well and capable. II-2, capable mentally. II -3 , capable and respected. II -4 , of a sociable, happy disposition. II- 7 , extremely nervous and sometimes irritable; had inventive ability; became a traveling salesman at 40. II-8, always nervous; generous, sociable, and active; became childish and hysterical. II-r 3 . slow, conscientious, and neat. III-3, musical; at 26 became reticent and resistive; later hallucinated, depressed and assaultive. III -4 , of a happy, even disposition. At 40 became peculiar and worried, reticent, depressed and seclusive and then restless, emotional and excited; had alternating moods. III-5, irritable, antagonistic, depressed and moody at times. III -6 , intelligent, capable, a bit reticent. III -7 , fond of social life, but somewhat nervous. III -9 , had weeping spells; was quick-tempered; at times depressed and worried and then very happy and optimistic. Developed delusions of persecution and hallucinations; attempted suicide at $35 ;$ now quiet and cheerful. III-10, had nervous prostration. $(44: 475)$.

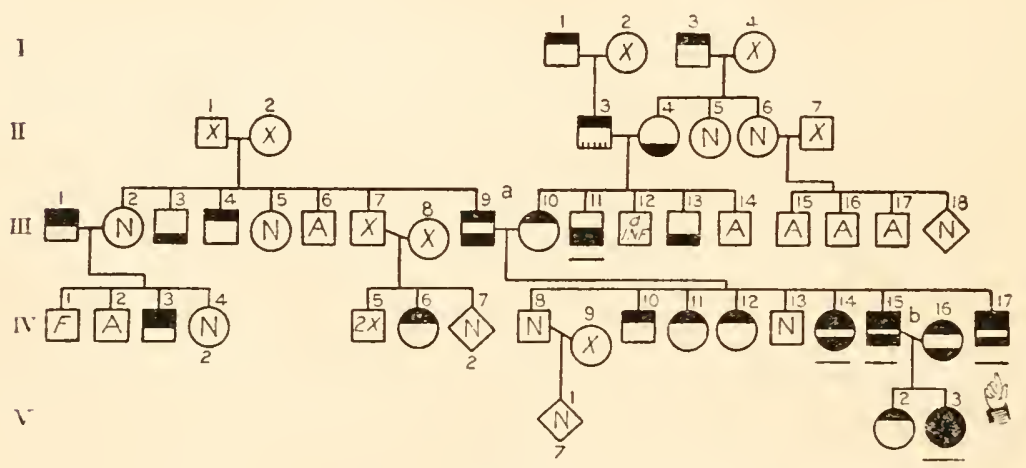

Fig. 80 .

FIGURE 80.-I-1, a State governor and United States senator. I-3, capable but alcoholic and "cranky." II-3, strong mentally but alcoholic, II-4, frail and delicate. III-I, alcoholic, committed suicide. III -3 , abnormally shy and retiring. III -4 , queer and alcoholic. III -7 , a rear-admiral of the United States Navy. III-9, brilliant; not practical; alcoholic; absentmindedness increased. III-IO, of a wonderfully happy, cheerful disposition. III-II, a bright young man who, when disappointed at 24, developed delusions and was in a hospital 40 years. III-13, has fainting spells. IV-I, a ne'er-do-well. IV -3 , committed suicide. IV -5 , both in the navy. IV -6 , travels and writes of her travels. IV -10 , clever and energetic. IV-I1, clever, energetic, artistic. IV-12, clever and intellectual. IV-I4, never gloomy, but cheerful; had fainting attacks; became excited and delusional; diagnosis, acute mania. IV-15, at times dull, confused, and resistive, then exalted, restless, talkative, silly, violent, homicidal, and hallucinated. IV -16 , emotional; depressed before childbirth; dramatic in speech and manner. IV -17 , at about 22 became confused and maniacal; then improved. V-2, attractive, frank, capable, fond of social life, but not normally intelligent. $\mathrm{V}-3$, belle of a southern city; was three times depressed; smoked many cigarettes; before admission to a hospital she was having a particularly gay time, drinking much; she became noisy and violent in language and action; on admission was over-active and over-talkative. with rhyming and flight of ideas; had active mania for 3 weeks. ( $(40: 189$.) 
Figure 8:-I-1, a chronic drunhard of ugly disposition. I-2, feeble-minded. II-1, despondent; threatened to kill her husband; had delusions of persecutions; became cross and irritable; 1I-3, degenerated after his marriage. II -4 , an insane imbecile; abusive and alcolıolic. 1I-5, extremely sensitive, nervous, irritable. and jealous. II-6, became morose and insane. II-7,

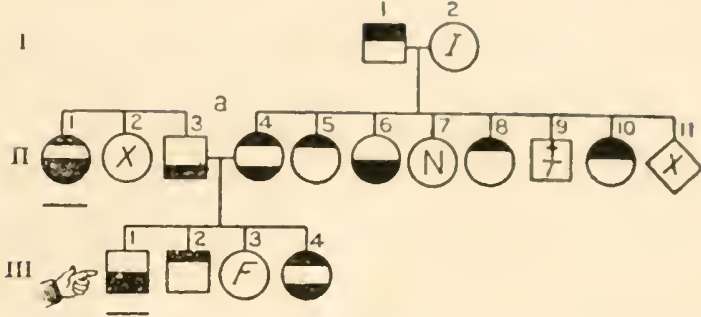

Fig. 8r.

quiet, peaceful, and steady. II-8, queer, peculiar; became insane. II-ro, nania for dress and decorations; has excited spells, when she flies into a rage. III-1, at 20 becane insane; tried to commit suicide; at times was greatly depressed. III-2, alcoholic; when angry struck. III-3, hecame violently insane. III-4, alcoholic, $S x$, feeble-minded. (2 : : 3 14 .)

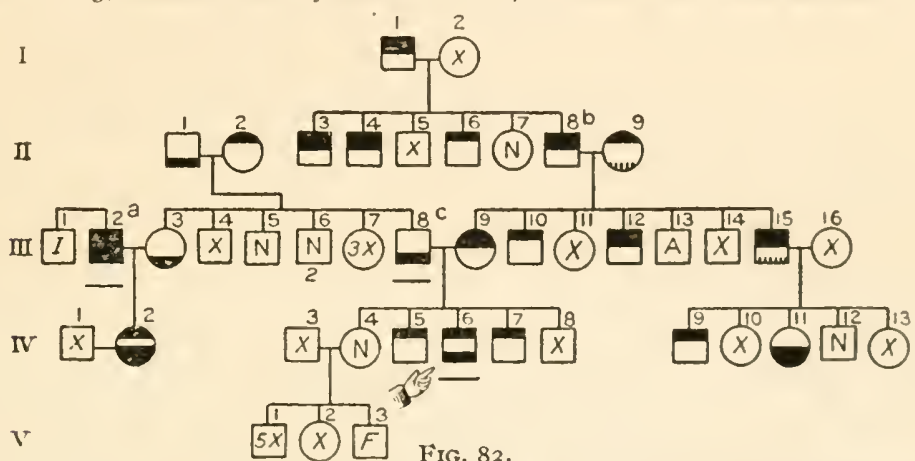

FIGURE 82.-I-1, harsh and brutal; became insane. II-1, pleasant, not nervous; had dizzy spells late in life. II-2, healthy and energetic, but became childish. II-3, ugly when on sprees; had dizzy spells later in life. II -4 , mentally unbalanced; never depressed; hanged himself in the barn. II-6, jolly. II-8, alcoholic in youth; become maniacal, chased family out-of-doors, flourished a razor, tried to shoot his wife; had religious mania. II-9, energetic. III-2, at 47 had melancholia; was restless, cross, abusive, delusional, and hypochondriacal; has excitable periods. III-3, pleasant and friendly; has a poor memory. III-8, was found wandering in a dazed way; now depressed, clildish, confused, and has petit mal seizures. III-9, hot-tempered, violent, excited, religious; threatened to cut her throat, and shot herself. III-10, feeble-minded; ran off with a circus. III-1 1, little known. III-12, violent, confused, and later demented. III-14, little known. III-15, a dipsomaniac; abusive to his children. IV-2, worried over her husband's infidelity and became emotional and suicidal; grew more nervous and worried; wished sle were dead. IV-4, good-natured, even-tempercd, well-poised (!). IV-5, ambitious; an occasional social drinker. IV-6, was always stubborn, self-willed, and a worrier; at 27 was mentally unbalanced; later had delusions of persecution and hallucinations; was suicidal. IV-7, quick-tempered; drinks. IV-9, (lrinks and is profane. IV-11, has delusions of persecution and is depressed. $(28: 1361$.)

Figure 83.-I-1, $S x$ and alcoholic. I-2. harsh-tempered. I-3, $S x$ and alcololic. I-5, w11an1bitious. II-I, committed suicide. I I -2 , of quict disposition. II-3, dishonest. I $1-4$, of good UI character. II -7 . of ugly temper;

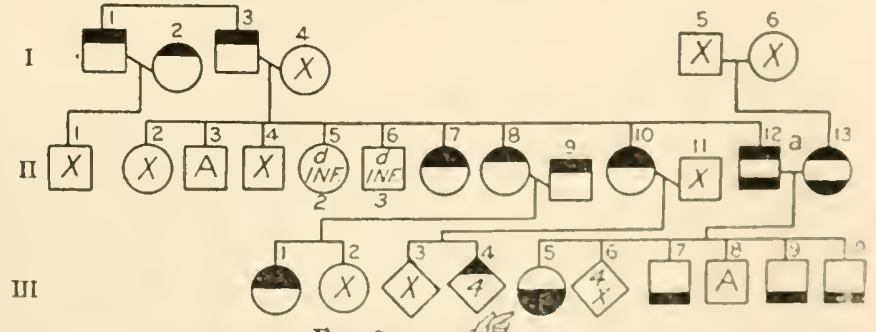

FIG. 83 . hounded two of her husbands to death. II -8, bad-tempered. II $-9, S x$ and alcoholic. II-so, of violent temper and tualicious disposition. II-12, dipsonaniac; of bad temper. II-13. erotic, but gentle and neat. III-I, bad-tempered and erotic. III-2, had nervous brcakdown. III-4, all bad-tempered. III-5, easily discouraged and depressed; watched lest she take her life. III-7, lenient and casy-going. III-9, alcoholic and very quict. III-10, lacks strength of claracter. $(34: 77$.) 


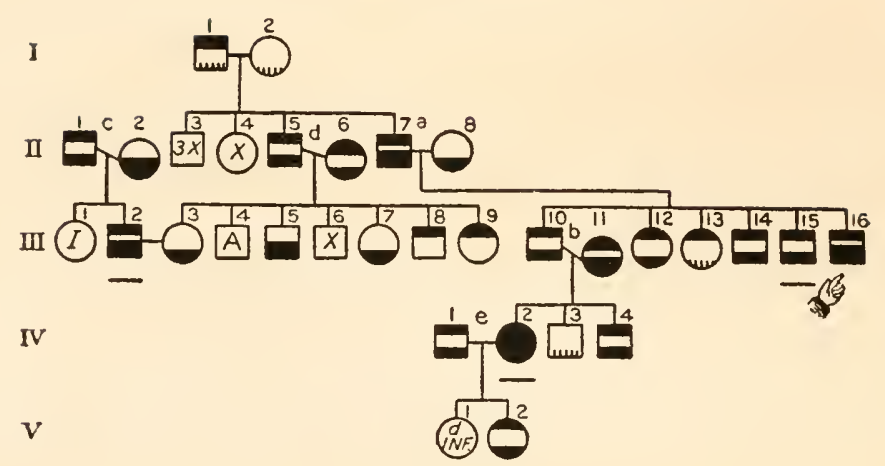

Fig. 84 .

FIgURE $84 .-$ I-1, energetic but slightly nervous. I-2, a strong, lovely character. II-I, committed suicide in delirium tremens. II-2, had delusions, attempted suicide by cutting arteries in her wrists. II-5, lively and talkative, but self-centered, stingy, and alcoholic. II-6, excitable, quick-tempered, moody, seclusive; came of "peculiar stock." II-7, morose, quiet, melancholy, reticent; had fits of anger and depression. II-8, quiet; of a mild and forgiving nature. III-2, alcoholic, $S . x$, morose; brooded over his troubles; became violent, later discouraged and hanged himself. III-3, quiet, modest, reticent and prond; died of grief. III -5 , alcoholic, $S x$, became discouraged and drowned himself. III-6, stubborn and wayward. III-7, quiet, bashful, and reticent. III-8, $S x$, alcoholic, restless, proud and inefficient. III-9, lively, popular, $S x$. III-10, alcoholic; $S x$; abusive to his wife; became insane. III-I1, nervous, melancholy, a trouble-borrower; was insane for a time. III-12, bashful, quiet, reticent, and irritable. III-13, jolly, happy, and lively. III-14, nervous and alcoholic. III-15,Sx, alcoholic, had delirium tremens; threatened to kill. III-16, alcoholic, $S x$, violent-tempered; arrested with delirium tremens, became desperate, and hung himself. IV-1, lazy, unambitious, liked a good time. IV-2, suspicious, superstitious, over-sensitive. quick-tempered, hysterical, $S x$; has delusions. IV-4, restless, alcoholic, $S x$; has wanderlust, $\mathrm{V}-2$, self-willed, obstinate, nervous, hyperactive; has fits of temper, but jolly and happy. $(21: 687$.

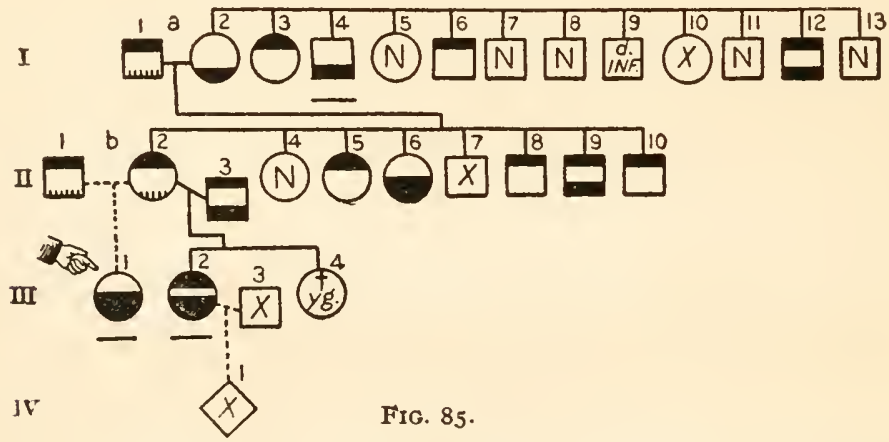

Figure 85, I-I, bad-tempered but sociable, well liked, and respected. I-2, died of senility. I-3, impulsive and highstrung. I-4, dull and stupid, stubborn and resistive. I-5, sociable and well liked. I-6, violent-tempered. I-8, of even disposition. I-1 1, sociable, well liked, and respected. I-12, nervous, highstrung, and irritable; at 63 became etnotionally unstable, lachrymose, and demented. II-I, $S x$, impulsive. II-2, quick-tempered, impulsive, $S x$, restless. II -3 , restless, discontented, unsociable. II-4, sociable and highly respected. II-5, impulsive, quick-tempered, sociable. II -6 , sociable and well liked, but has delusions of poverty. II-8, sociable, quick-tempered, active, and alert. II-9, seclusive, quicktempered and moody. II-10, went West when young. III-1, worried; at 29 became depressed, melancholy, restless; at 30 again depressed and wept easily; at 36 had delusions of persecution; attempted suicide almost daily; now seems cheerful and contented, but inclined to be seclusive. III -2, passionate and emotionally unstable, highstrung and nervous; had headaches and crying spells. (41:321.) 


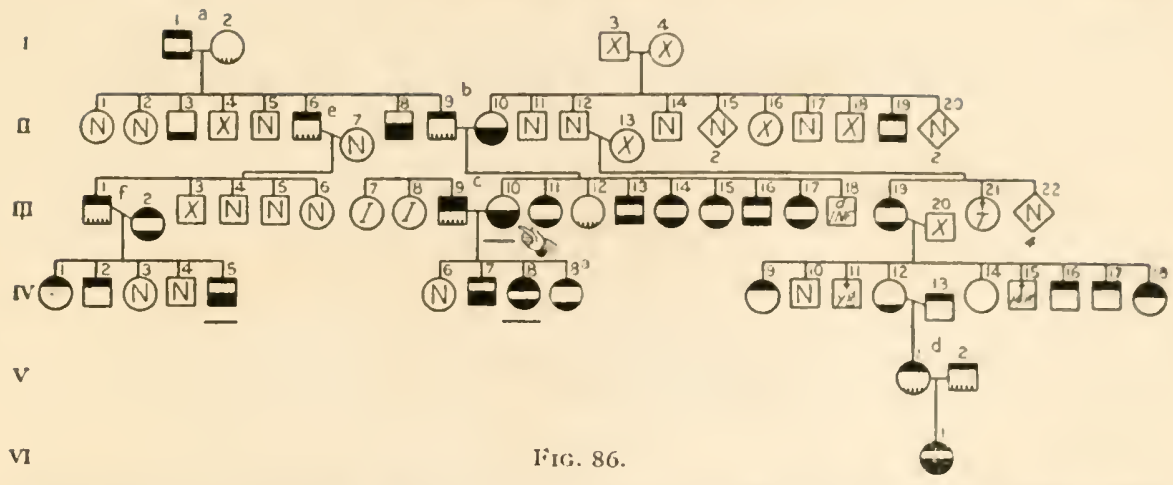

FIGURE 86.-1-1, submental; lazy, irritable, impatient, disagreeable; acted insanely after drinking. I-2, intelligent and capable. I-3, had "palsy." II-3, sensitive and bashful, but quiet and ealm. II-5, intelligent and normal. II-6, witty and intelligent; full of fun and jolly. II-8, not bright; jealous, morose, despondent, unsocial; hanged himself. II -9 . nervous, excitable, impulsive, musical. II-10, nervous; cried easily and worricd; at 25 had a depressed spell. II-19, sensitive, quiet; wandered off; acted and talked strangely. III-r, ambitious and hard-working. III-2, highstrung, hysterical, and bad-tempered; has neuritis. III-3, died of nervous exhaustion and paralysis. III-4, easy-going. III -9 , irritable, exeitable, critical, unsympathetic. III-10, calm and quiet, but apt to brood and worry; always depressed; at 42 became confused, delusional; spoke of suicide, and asked to be hung. III-11, irritable, very religious, eccentric. III-12, not nervous; well physically and mentally. III-13, stubborn, impatient, irritable. III-14, excitable; worries over everything; very religious; sumy in disposition. III-15, nervous, excitable, impatient, very nervous; oftell can not sleep nor eat; a worrier. 1II-19, nervous and apt to worry. IV-1, $S x$. IV $-2, S x$; had delirium tremens. IV -5 , quiet; worried over a love affair and became agitated and depressed; had delusions of a sexual nature and at 24 hanged himself. IV 6 . calm, dignified, and reserved. IV -7 , nervous and embarrassed as a boy; restless; a worrier; had migraine and was depressed. IV-8, always excitalle, irritable, hysterical, and hightempered; had convulsions; previous to her first child's birth she had nervous prostration. with convulsions and attacks of laughing; later she became viulent and attempted suicide; had hallucinations. IV-8a, worried all the time; was easily excited, being like a "huge explosive ready to go off." IV-9, energetic and quick. IV-12, phlegmatic and happy-golucky. IV-13, quick, energetic, rather nervous, aleoholic. IV-16, odd and ecentric, miserly. impulsive, and irritable, IV-7, irritable, erratic, irresponsible, musical. IV-18, hightempered, extravagant; committed suicide by jumping out of window. $V-r$, energetic and nervous. V-2, always wild, $S x$, and alcoholic. VI-1, at 5 had epilepsy; became irritable, violent and actively hallucinated; when depressed threatened suicide. (25:158.)

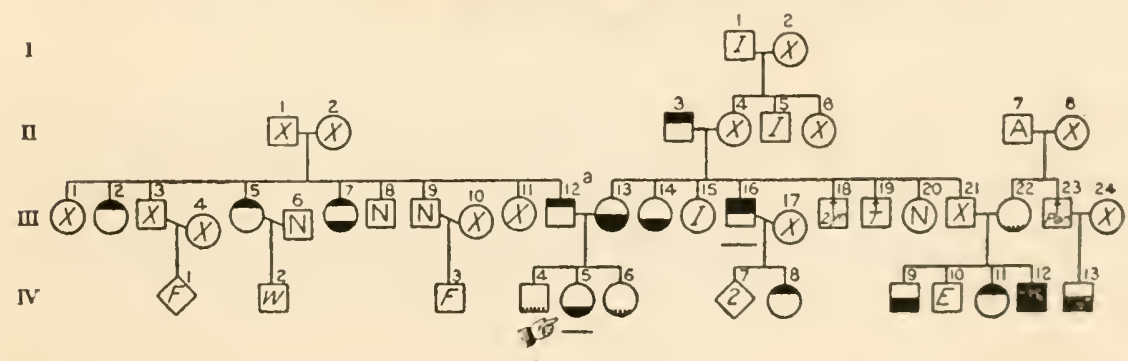

Fig. 87 .

FigURE 87,-II-3, a "driver" in his work and in working others. III-1, had prononnced likes and dislikes. III-2, cheerful and full of fun. III-5, had peculiar religious ideas and delusions of persecution. III-7, had headaches; was highstrung and proud. III-8, genial. III-1 2, set and stubborn, ambitious and detcrmined. III-13. quict, mild, and sweet; became depressed and tried to conmit suicidc. III-14, peculiar, hyper-religions. III-15, effective and reticent; insane before death. III-16. manic-depressive of manic form. III-22, secms fairly normal. IV -5, intensely religious - inclined to hysteria; had fits of temper; homicidal at 52. IV-6, ealm and determined. An hexual delusious; is irritalie and has dementia precox. I $\mathrm{V}-9$, at 47 had an involutionn puchosis; was neurasthenic and later depressed. IV-11, high-tempered. IV-12, depressed; -hyigious delusions, later violent and obscene; tried to jump ont the window; cried; later depensed and delusional. Il -13. killed himself by cutting his wrists. (1 $1: 189$. 


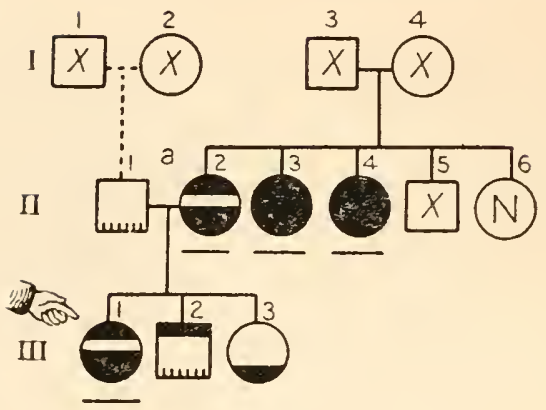

FIG. 88 .

FigURE 88.-I-3, comes of an alcoholic fraternity. I-4, had severe headaches. II-I, easy-going and temperate. II-2, was alternately depressed and excited; threatened suicide, to burn her home, and to poison her husband. II-3, sociable and well-liked, but at 40 became melancholy. depressed, and suicidal; later was excited, silly, and lascivious. II-4, epileptic, excitable, quick-tempered, irritable, hysterical; developed delusions against her husband; had alternate periods of excitement and depression; attempted to set fire; was hallucinated. II-5, sociable, mild, and reticent, alcoholic. III-6, pleasant, not nervous. III-1, lacked capacity for work; was irritable, sometimes silent and sullen and then talkative; at 17 had period of depression; became $S x$; at 28 at hospital, complained of many aches and pains. III-2, eccentric, somewhat excited in manner. III -3 , complains of nervousness. $\quad(41: 316$.

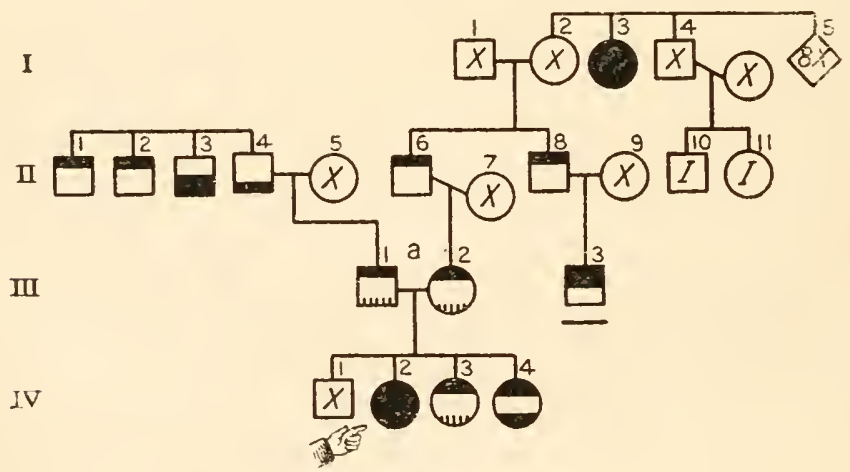

FIG. 89 .

PIgure 89.-I-3, a manic depressive. II-1, gambler. II-2, gambler. II-3, had spells of drinking followed by melancholia, in one of which he committed suicide. II-4, a senile dement. II -5 , had paralytic insanity. II -6 , alcoholic; subject to spells of being "rattled." II-8, violent-tempered. III-I, erotic and alcoholic. III-2, Sx. III-3, had violent fits of temper; became very noisy; has recurrent mania. IV-2, $S x$; has brief periods of fury alternating with deep melancholia; has attempted suicide. IV-3, nervous, but of strong character. IV-4, untruthful and unreliable; somewhat weak and selfish. $(9: 78$.

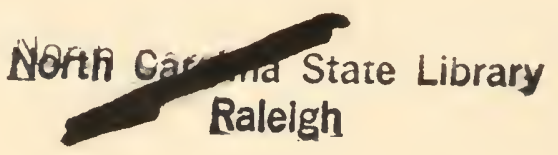




